\title{
Corporate governance and sustainability in global property markets
}

Citation for published version (APA):

Kok, N. (2008). Corporate governance and sustainability in global property markets. [Doctoral Thesis, Maastricht University]. Maastricht University. https://doi.org/10.26481/dis.20081128nk

Document status and date:

Published: 01/01/2008

DOI:

10.26481/dis.20081128nk

Document Version:

Publisher's PDF, also known as Version of record

\section{Please check the document version of this publication:}

- A submitted manuscript is the version of the article upon submission and before peer-review. There can be important differences between the submitted version and the official published version of record.

People interested in the research are advised to contact the author for the final version of the publication, or visit the DOI to the publisher's website.

- The final author version and the galley proof are versions of the publication after peer review.

- The final published version features the final layout of the paper including the volume, issue and page numbers.

Link to publication

\footnotetext{
General rights rights.

- You may freely distribute the URL identifying the publication in the public portal. please follow below link for the End User Agreement:

www.umlib.nl/taverne-license

Take down policy

If you believe that this document breaches copyright please contact us at:

repository@maastrichtuniversity.nl

providing details and we will investigate your claim.
}

Copyright and moral rights for the publications made accessible in the public portal are retained by the authors and/or other copyright owners and it is a condition of accessing publications that users recognise and abide by the legal requirements associated with these

- Users may download and print one copy of any publication from the public portal for the purpose of private study or research.

- You may not further distribute the material or use it for any profit-making activity or commercial gain

If the publication is distributed under the terms of Article $25 \mathrm{fa}$ of the Dutch Copyright Act, indicated by the "Taverne" license above, 


\section{Corporate Governance and Sustainability in Global Property Markets}

proefschrift

ter verkrijging van de graad van doctor aan de Universiteit Maastricht, op gezag van de Rector Magnificus, Prof. mr. G.P.M.F. Mols, volgens het besluit van het College van Decanen,

in het openbaar te verdedigen op vrijdag 28 november 2008 om 12.00 uur.

door

Nils Kok 


\section{Promotor:}

Prof. dr. P.M.A. Eichholtz

Beoordelingscommissie:

Prof. dr. R.B.M. Bauer (voorzitter)

Prof. dr. D. Brounen (RSM Erasmus)

Prof. dr. J.M.E. Pennings 


\section{Voorwoord}

Internetcafé, Kuala Lumpur, 21/6/2004

Beste Nils,

Om je te helpen de promotie-optie te verkennen stuur ik je wat nadere informatie.

De grote vraag is natuurlijk waarom juist jij zou moeten promoveren. Dat is gemakkelijk: er zijn in de internationale vastgoedpraktijk maar een beperkt aantal mensen die echt diep nadenken, dus mensen die dat wel doen of gedaan hebben, die kunnen heel ver komen. Aan de andere kant zijn er in de academische wereld maar weinig mensen die praktisch kunnen denken en dynamisch kunnen opereren. Ik denk dat jij dat wel zou kunnen. Kortom, met de verdieping op zak die een promotie je biedt, ben jij in staat om op het hek te zitten tussen de wetenschap en de praktijk en ik kan je uit eigen ervaring vertellen dat dat een heel comfortabel hek is.

Kortom, het lijkt mij een goed idee voor je. Ik heb er zelf nooit een moment spijt van gehad.

Groeten en wijsheid,

Piet

Amsterdam, 21/9/2008

Vier enerverende jaren later is dit voorwoord het laatste wat nog aan mijn proefschrift rest. Een ongeëvenaarde leercurve met de vrijheid waar een student van droomt. Een algemene ontwikkeling die een wereldreis teniet doet. En een persoonlijk ontwikkelingsprogramma waar een gemiddeld traineeship bij verbleekt.

Ik heb de tijd mee. Met de jaren is de relevantie van dit proefschrift toegenomen. De recente vastgoedfraude heeft de meeste Nederlandse institutionele investeerders die nog in direct vastgoed investeerden van gedachten doen veranderen. Toezicht op de financiële sector is in de huidige marktsituatie weer het gesprek van de dag. Om over de maatschappelijke discussie betreffende compensatie van topmanagement nog maar niet te spreken. De sterk fluctuerende, maar overwegend stijgende prijs van fossiele brandstoffen en ruwe materialen heeft de vastgoedsector wakker geschud. Duurzaamheid in de gebouwde omgeving is onontkoombaar: eindgebruikers 
en eindbeleggers vragen niet, maar eisen dat de vastgoedsector zich conformeert aan maatschappelijk verantwoorde bouwstandaarden.

Het doet mij deugd de academische - doch overwegend empirische - boodschap in dit proefschrift te kunnen vertalen naar de praktijk. Want mijn zoektocht naar erkenning wordt niet bevredigd door enkel academische prestaties, die vaak pas op de lange termijn resultaat opleveren. Al genereerde het proces van dit proefschrift een overdaad aan korte termijn vreugde: variërend van een half jaar Berkeley tot drie dagen New York, van academische conferenties tot een lezing voor zeshonderd 'boeren, burgers en buitenlui' en van publicaties in praktijkbladen tot de eerste exposure in landelijke dagbladen. Maar ook de langere termijn komt uiteindelijk dichterbij, met papers verschijnend in academische journals en - ook ik - van een vrijgezellenbestaan naar een duurzame relatie.

Het misschien wel grootste voorrecht van het academisch bestaan is mijns inziens het onbeperkte, onbegrensde en - vanuit een duurzaam perspectief - onverantwoorde reizen. Weg van het dagelijkse leven, vanaf het moment van opstijgen of wegrijden een overweldigend gevoel van innerlijke rust. Dit proefschrift heeft zijn oorsprong op een veelvoud van schitterende locaties, van San Francisco tot Shanghai, van de Grand Canyon tot Hong Kong. De dynamiek van het reizen geeft inspiratie en de ervaring met andere culturen leert je de theorie in een breder perspectief te zien. Een deel van mijn dank gaat hierbij uit naar het European Center for Corporate Engagement (ECCE), wat een selectie congressen en dit proefschrift financieel mede mogelijk maakte.

Maar zelfs als de sky - figuurlijk en letterlijk - de limit is, zitten er nog steeds maar vierentwintig uur in een dag, en gemiddeld maar zeven dagen in een week. En de uren die je deze week verliest, haal je volgende week niet meer in. Kwanti-tijd moet dus feitelijk kwali-tijd zijn. Mijn dank aan mijn vrienden, die allen bereid zijn op deze manier onze vriendschap te onderhouden. Mijn bewondering voor Lian, misschien wel de enige die in staat is om de knop in mijn hoofd om te zetten. En natuurlijk mijn ouders. Al was het maar om van wetenschap naar begrijpelijke taal te komen. Vanuit hun bosrijke omgeving is er altijd een luisterend oor, of de mogelijkheid tot fysiek ontspannen op de schier onuitputtelijke voorraad hout.

De weg naar doctor was als een spannende fietstocht. In een van mijn stellingen refereer ik naar Alpe d'Huez als metafoor, maar eerlijkheid gebied mij te zeggen, het voelde lang niet altijd als bergop. Het steuntje in de rug kwam van talrijke kanten, maar bovenal van (fiets-) overleg met Piet. In mijn vriendenkring inmiddels een begrip. In mijn perceptie geestelijk vader tijdens mijn opgroeien in de academische wereld. Veel dank voor de uitstekende begeleiding en...ik kom graag naast je op het hek zitten. 


\section{Table of Contents}

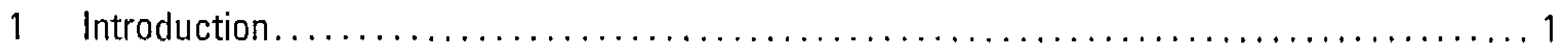

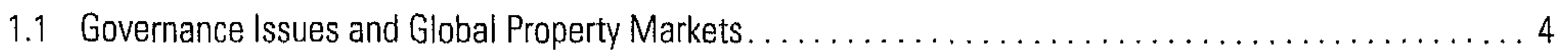

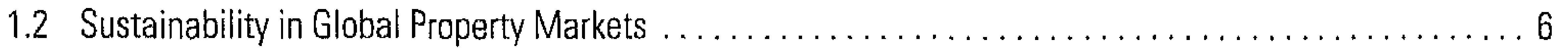

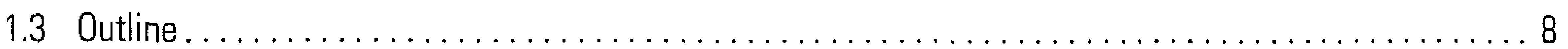

\section{Part ONE: Corporate Governance in Global Property Markets}

2 How Does the Market for Corporate Control Function for Property Companies? ........... 13

2.1 Introduction . . . . . . . . . . . . . . . . . . . . . . . . . . . . . . . . . . . . . . . . 15

2.2 Literature review: the Inefficient Management Hypothesis . . . . . . . . . . . . . . . . . . . . . 17

2.2.1 Pre-acquisition Performance of Targets. . . . . . . . . . . . . . . . . . . . . . . . . . . . . 17

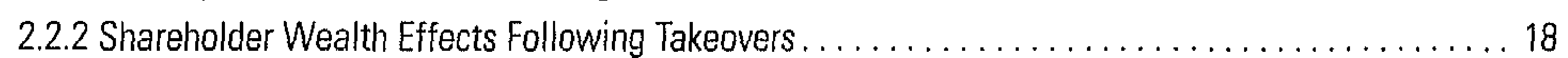

2.3 Data . . . . . . . . . . . . . . . . . . . . . . . . . . . . . . . . . . . . . . . . . 19

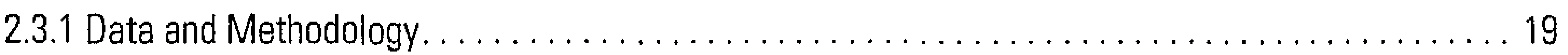

2.3.2 Descriptive Statistics . . . . . . . . . . . . . . . . . . . . . . . . . . . . . . . . . 20

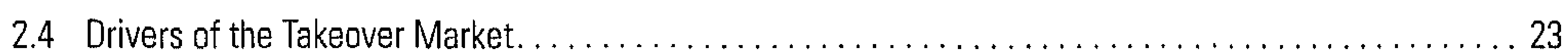

2.4.1 Pre-Acquisition Performance . . . . . . . . . . . . . . . . . . . . . . . . . . . . . . . . . 23

2.4.2 Univariate Analyses . . . . . . . . . . . . . . . . . . . . . . . . . . . . . . . . . . . . 24

2.4.3 Multivariate Results. . . . . . . . . . . . . . . . . . . . . . . . . . . . . . . . . 27

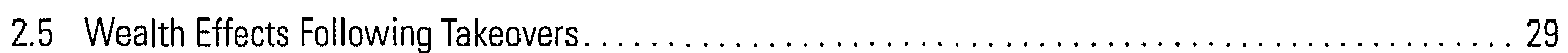

2.5.1 Methodology . . . . . . . . . . . . . . . . . . . . . . . . . . . . . . . . . . . . . . 30

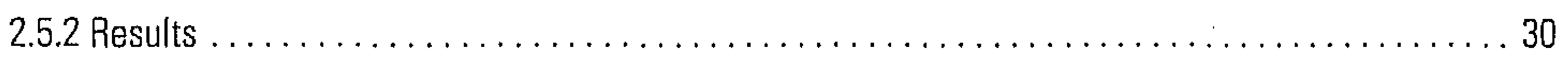

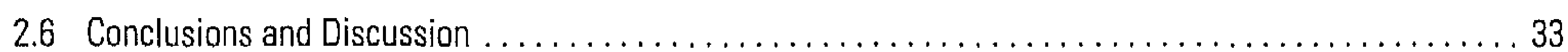

3 Executive Compensation in U.K. Property Companies. ........................ 37

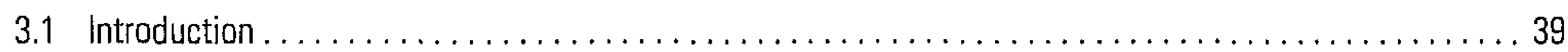

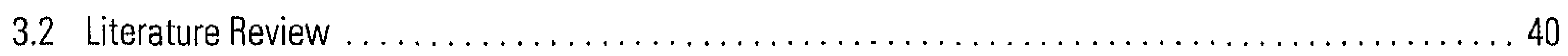

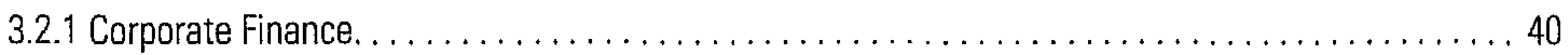

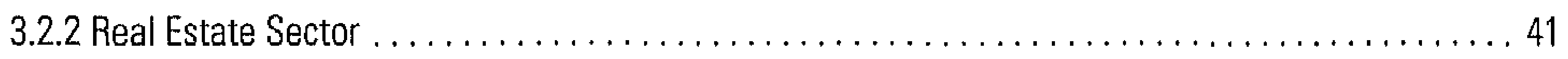

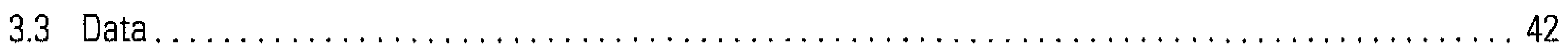

3.4 The Level of Executive Compensation. ................................ 47

3.4.1 Economic- and Accounting Measures of Performance ........................ 48

3.4 .2 Governance Mechanisms . . . . . . . . . . . . . . . . . . . . . . . . . . . . . . . . . . 49

3.4.3 Asset Characteristics . . . . . . . . . . . . . . . . . . . . . . . . . . . . . . . . . . . . . . . 50

3.5 Changes in Executive Compensation; The Pay-Performance Sensitivity (PPS) . . . . . . . . . . . . 54

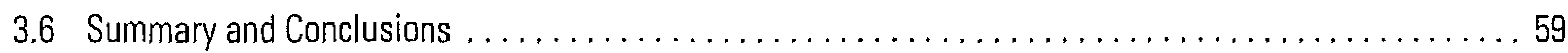


4 Corporate Governance and Performance: The REIT Effect $\ldots \ldots \ldots \ldots \ldots \ldots \ldots \ldots \ldots \ldots$

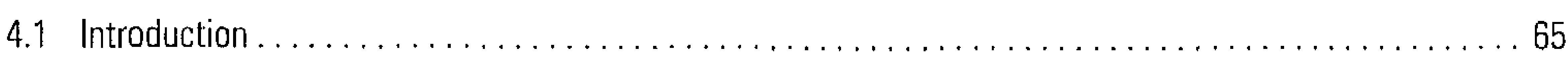

4.2 Literature Review: Corporate Governance and Performance $\ldots \ldots \ldots \ldots \ldots \ldots \ldots \ldots \ldots \ldots 7$

4.3 Data . . . . . . . . . . . . . . . . . . . . . . . . . . . . . . . . . . . . . . . . . 69

4.4 Empirical Analysis: Firm Value and Operating Performance. . . . . . . . . . . . . . . . . . . . . . 72

4.4.1 Full sample: Governance, Firm Value and Operating Performance . ................... 72

4.4.2 REITs: Governance, Firm Value and Operating Performance . . . . . . . . . . . . . . . . . . . . 76

4.4 .3 Control Samples . . . . . . . . . . . . . . . . . . . . . . . . . . . . . . . . . . . . . . . . . 80

4.4.3.1 Firms with High Corporate Real Estate Ratios . . . . . . . . . . . . . . . . . . . . . 81

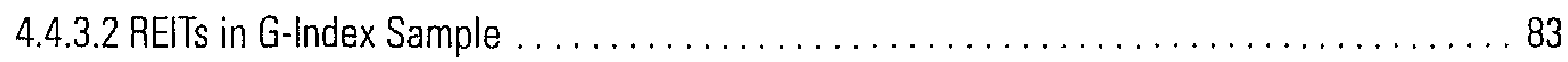

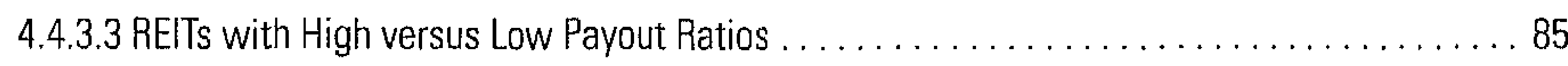

4.5 Concluding Remarks . . . . . . . . . . . . . . . . . . . . . . . . . . . . . . . . . . . . . . 87

\section{Part TWO: Sustainability \& Real Estate}

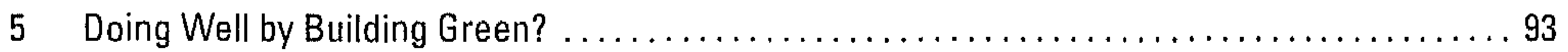

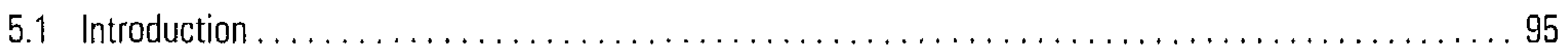

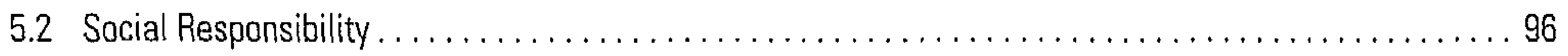

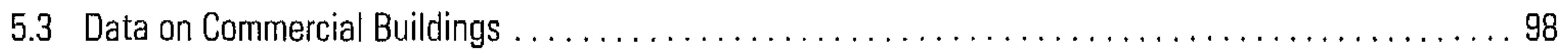

5.3 .1 The Analysis Sample ............................................ 101

5.4 Empirical Analysis and Results. ...................................... 107

5.4 .1 Methods ..................................................... 107

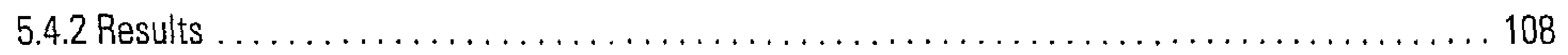

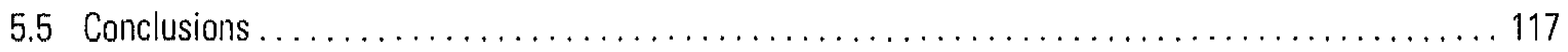

6 Why Companies Rent Green: CSR and the Role of Real Estate ................. 123

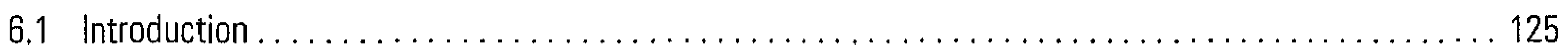

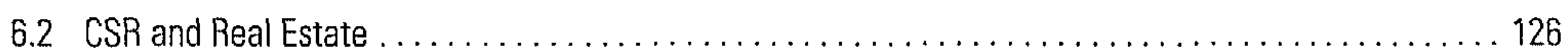

6.2.1 Drivers of CSR Adoptiveness in Real Estate . . . . . . . . . . . . . . . . . . . . . . . 127

6.2.1.1 Direct Economic Benefits. . . . . . . . . . . . . . . . . . . . . . . . . . . . . . . . . . . . . 127

6.2.1.2 Indirect Economic Benefits. . . . . . . . . . . . . . . . . . . . . . . . . . . . . . . 128

6.2.1.3 Risk Avoidance. . . . . . . . . . . . . . . . . . . . . . . . . . . . . . . . . . . . . . . . . . . . 129

6.2.1.4 Ethical Behavior . . . . . . . . . . . . . . . . . . . . . . . . . . . . . . . . . . . . . . 130

6.2 .2 Propositions . . . . . . . . . . . . . . . . . . . . . . . . . . . . . . . . . . . . 130

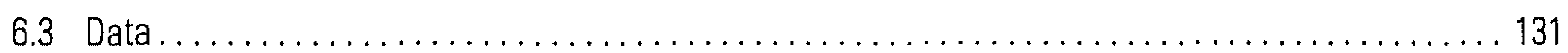

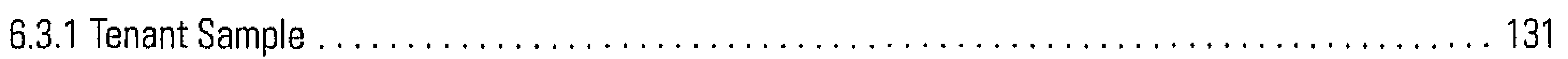

6.3 .2 Control Sample. . . . . . . . . . . . . . . . . . . . . . . . . . . . . . . . 136

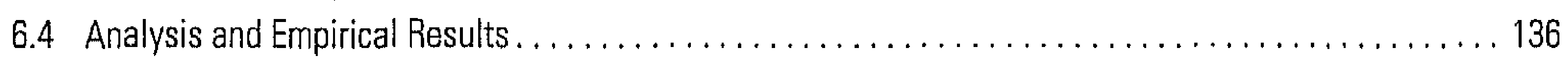

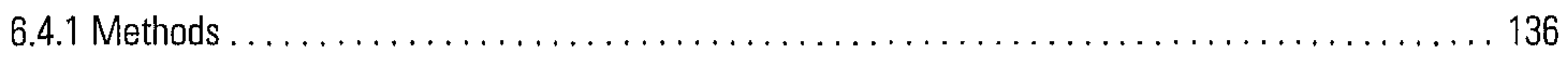

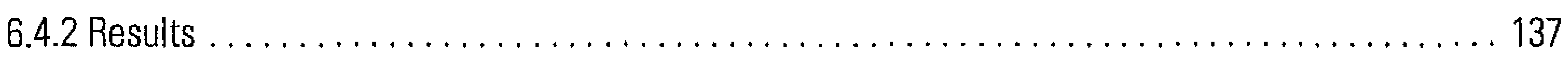

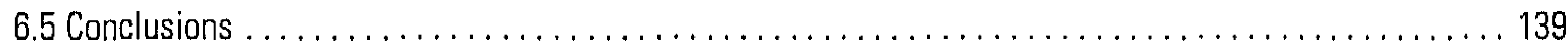




\section{Part THREE: Conclusions}

7 Summary, Practical Implications and Further Research....................... 145

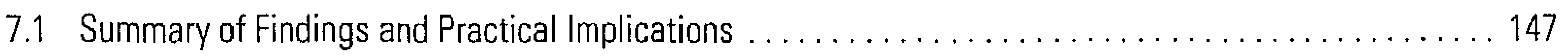

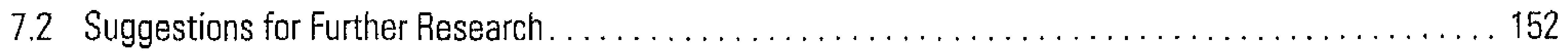

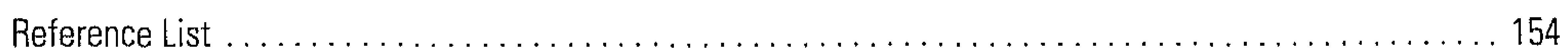

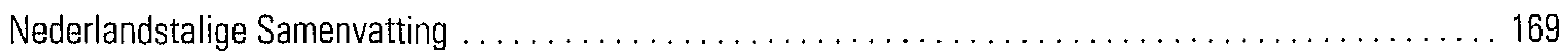




\section{Introduction}




\section{Introduction}

In the course of the Twentieth Century, most industries were completely run by corporations. One notable exception was the field of real estate, which is illustrated by Berle and Means, stating in 1932: "most real estate is held by private corporations...although real estate now shows signs of coming within the corporate sphere." It would take a few more decades until real estate corporations would really take off. The introduction of the U.S. Real Estate Investment Trust (REIT), following the REIT Act (IRS, Section 856) in 1960 signifies an important milestone. The REIT structure was introduced to allow private citizens to gain exposure to real estate investments while avoiding traditional barriers to invest, such as illiquidity, lumpiness of the investment, and the need to have adequate knowledge of the local property market. The REIT status provides real estate corporations with a tax-transparent status, i.e. income is not taxed at the corporate level, to put the shareholder on equal footing with an investor who owns a property portfolio outright. To ensure ultimate taxation at the investor level, REITs have to distribute 95 percent of net income. Moreover, REITs are bound to various other rules and regulations. ${ }^{1}$

The Netherlands and Australia soon followed suit and implemented a listed property structure similar to the U.S. REIT example, in 1969 and 1971 respectively. However, the growth of the indirect - listed - real estate market was initially hampered due to complicated rules and regulations restricting REITs. The Tax Reform Act of 1986, followed by the REIT Simplification Act of 1997, and the REIT Modernization Act of 1999, significantly modified policy constraints that had been imposed on U.S. REITs at the beginning. The 1986 Act for example permitted REITs not merely to own, but also to operate and manage most types of income producing commercial properties.

In a parallel development, institutional investors around the world started to allocate an increasing part of their capital to real estate, recognizing the virtues of real estate as a diversifier in a mixed-asset portfolio (Eichholtz, 1997. Goetzmann and Ibbotson, 1990); real estate transformed from alternative investment to the 'third asset class'. However, by directly investing in real estate, institutional investors were acting as property managers rather than passive end-investors. Moreover, international diversification of the institutional property portfolio the most efficient form of risk-reduction - was extremely costly due to the necessity of local presence. Gradually, large investors started to shift capital towards indirect property investments, sometimes in conjunction with securitization of their existing property portfolio. For example, $A B P$, a large Dutch pension fund, spun off its Dutch property portfolio in three different vehicles - Vesteda, KfN, and Corio - and sold stakes to other institutional investors. Currently, Dutch institutional investors hold approximately 50 percent of real estate assets indirectly, up from only three percent in 1980. Especially for international real estate investments, property companies represent the avenue of choice: Hermes, a British pension fund, holds approximately 80 percent of its foreign real estate assets through listed property companies.

1 The specific legal requirements that REITs have to adhere to, vary widely per country. We refer to Eichholtz and Kok (2007) for a detailed overview. 
The increased institutional demand for indirect property investments, combined with a worldwide thirst for capital, led to a rapid increase in market capitalization of the listed property sector. To illustrate, the combined market capitalization of the listed property markets in Asia, Europe and the Americas increased from $€ 27$ billion in 1985 to $€ 1.2$ trillion in 2007. Most notable was the period from 2003 through 2007: in four years, the combined market capitalization increased with $€ 800$ billion. Part of this growth can be attributed to the rapid global roll-out of REIT-regimes, which puts indirect property investments - from a tax point-of-view - on par with direct property investments.

\subsection{Governance Issues in Global Property Markets}

A major implication of the private real estate industry transforming into the corporate system is the separation of ownership and control. Where property investments used to be directly managed by investors, a stake in either listed or non-listed property vehicles yields the need for appropriate command and control mechanisms. Enter corporate governance. A term coined in the 1990s, in its broadest sense describing the system of legal rules and regulations that are in place to tie the interest of those in control to the owners of a corporation - different scholars vary widely in where they draw the boundaries of this subject. In the real estate sector, an important governance issue is for example whether property companies should be internally or externally managed. Indeed, Howe and Shilling (1990). Hsieh and Sirmans (1991) and Ambrose and Linneman (2001) all show that the performance of internally advised REITs dominate externally advised REITs. Consequently, the industry has resolved this issue and externally managed U.S. REITs virtually disappeared. However, 23 externally advised property companies had an initial public offering on the London Alternative Investment Market in 2005 and 2006. This is but one indication that with the development of a true global property market, there is need for better understanding of corporate governance in non-U.S. property markets. In addition, the distinct legal setting in which most REIT regimes operate, changes - and thereby possible complicates - the traditional principal-agent setting. This is especially relevant due to the large number of REIT regimes worldwide, each with its own rules and regulations.

The first part of this dissertation addresses the need for in-depth academic research into the structure and functioning of corporate governance mechanisms in the listed property sector. A new stream of literature related to corporate governance in listed property companies has already started to emerge, but there are still important gaps in this immature literature, and moreover, the current literature merely focuses on the U.S. REIT market. We contribute to the corporate governance literature in two distinct ways. First, we study the functioning of two specific governance mechanisms in the global property market - the market for corporate control and executive compensation. Second, this dissertation adds to the understanding of the REIT structure and - more specifically - how this structure affects corporate governance.

\section{The Market for Corporate Control}

The theory on the market for corporate control posits that shareholders are able to vote control to that management team which offers most economic value. The pressure of the market disciplines those in control, and in addition, the occurrence of a takeover corrects for managerial failure by replacing underperforming or opportunistic managers. Indeed, Manne (1965) states that "...only the take-over scheme provides some 
assurance of competitive efficiency among corporate managers and thereby affords strong protection to the interests of vast numbers of small, non-controlling shareholders". Perceived as one of the most effective governance mechanisms available to shareholders (Rappaport, 1990), there are a few concerns though: (1) the dispersion of shareholdings leads to negligence by small shareholders, (2) the existence of a takeover threat might induce managers to focus on short-term goals rather than long-term value maximization (Stein, 1988), and; (3) manipulation of the bidding process by those in control of bidding firms, triggered by the empire-building syndrome of corporate management (Baumol, 1959).

In the real estate sector, some REIT regimes operate under restrictions on the ownership structure. For example, in the United States, the five largest shareholders in REITs cannot hold more than 50 percent of the shares outstanding (institutional investors are exempted from the rule) and the minimum number of shareholders is one hundred. Originally implemented to facilitate retail investors (Friday, Sirmans and Conover, 1999), some academics have argued that the restrictions enhance dispersed ownership and therefore obstruct a proper functioning of the market for corporate control. This would explain the lack of hostile takeovers that has been previously documented in the U.S. REIT market (Allen and Sirmans, 1987, Campbell, Ghosh and Sirmans, 2005 , Ghosh and Sirmans, 2003b, 2006). As all studies are based on the U.S. REIT market, the globalization of the market for corporate control in the property sector is merely ignored, whereas Asia and Europe make up more than two-third of the listed property market. We therefore study the market for corporate control in a global context. Moreover, the absence of hostile takeovers in the listed property sector has not been properly addressed in the literature hitherto. Is this a signal of an inefficient real estate takeover market, or is it merely due to the regulatory constraints imposed on REITs? By examining the drivers of takeovers rather than the effects, this dissertation is able to unravel the functioning of the market for corporate control in the listed property market.

\section{Executive Compensation}

Executive compensation in theory represents an excellent governance mechanism: if owners manage to set a compensation policy that ties the CEO's welfare to shareholder wealth, this provides incentives for CEOs to take the appropriate actions in order to maximize corporate value (Jensen and Murphy, 1990). There are various compensation mechanisms through which compensation policy can align the potentially non-congruent goals of owners and those in control, such as including performance-based bonuses and salary revisions, stock options, and performance-based dismissal decisions. However, having been topic of a heated debate since decades, executive compensation seems to have reached every goal, but enriching those in control at the expense of the owners of a corporation. Even today this leads to public outcry and the threat of government intervention, with European countries such as The Netherlands and France, as well as U.S. presidential candidate John McCain, denouncing extravagant executive salaries. ${ }^{2}$ We refer to Bebchuk and Fried (2005), who provide an excellent thesis on executive compensation practices.

Regarding executive compensation in the real estate sector, we focus on the U.K. property market, unlike previous compensation research, which is all based on U.S. REITs (Chopin, Dickens and Shelor, 1995, Ghosh and Sirmans, 2005, Pennathur, Gilley and Shelor, 2005, Pennathur and Shelor, 2002, Scott, Anderson and Loviscek, 2001). A REIT-like structure was implemented in the United Kingdom in January 2007 only, and thus has not been

2 The Economist, June 14, 2008. 
available until very recently. The lack of a REIT structure implies that unlike their U.S. counterparts, U.K. property companies were not obliged to distribute at least $90 \%$ of income. Therefore, we expect agency problems to be more severe in the U.K. listed property market than in the U.S. REIT market. Incentive-based compensation is one way to align interests of principal and agents, and insight in executive compensation practices of property companies in the United Kingdom might be helpful in a better understanding of corporate governance in property companies without a REIT-status.

\section{REITs and Corporate Governance}

The patchwork of operational restrictions that currently applies to the different global REIT regimes has distinct effects on the institutional setting in which REITs operate. For example, 75 percent of the income of REITs should be derived from real estate or related operations, and investments in development activities are not allowed. Moreover, 75 percent of the value of total REIT-assets should consist of real estate assets, cash or cash items. Several authors argue that these restrictions are detrimental to corporate governance standards, as they hinder 'managerial experience of executives in RElTs' (Campbell, Ghosh and Sirmans, 2001, Ghosh and Sirmans, 2003b. Whidbee, 1997). In this case, it can be hypothesized that the legal setting in which RElTs operate should be complemented by internal corporate governance mechanisms - as in regular corporations - to prevent managerial entrenchment and to reduce agency problems to a minimum.

On the other hand, one could argue that the limited investment opportunities for those in control restrict diversification opportunities, which reduces the possibility of management engaging in value-destroying activities outside the focus of operations. Moreover, the value of a REIT portfolio, consisting of appraisable real estate, can be established relatively easy as compared to the complex operations of firms in for example the manufacturing or pharmaceutical sector. Under the substitution hypothesis (La Porta, Lopez-De-Silanes, Shleifer and Vishny, 2000), the legal restrictions regarding REITs might mitigate the need for strong internal corporate governance mechanisms, i.e. corporate governance is less likely to be important for REITs than for regular corporations (Hartzell, Kallberg and Liu, 2004). This dissertation addresses both hypotheses by examining the relation between corporate governance and performance in REITs. It thereby provides insight in the relevance and effectiveness of corporate governance mechanisms in the U.S. listed property sector.

\subsection{Sustainability in Global Property Markets}

With the institutionalization of the real estate industry, the needs and wants of the owners are playing an increasingly important role. We pose in the first part of this dissertation that knowledge of the structure and functioning of corporate governance mechanisms is therefore quintessential. However, corporate governance is solely addressing the principal - agent conflict. Corporate social responsibility, or the basic moral rules of business, is broader than just corporate governance: it also incorporates environmental sustainability and social policies of the corporation. Retail as well as institutional investors now increasingly recognize the importance of non-monetary utility brought by CSR, and incorporate the extent of corporate engagement in their investment decisions. As such, the supply side of the capital market can drive the socially responsible behavior of corporations. And it acts accordingly. For example, in 2007, the major Dutch pension funds unanimously declared to abstain from investing in corporations with 'irresponsible' operations, and to integrate corporate 
social responsibility in their investment decisions. Moreover, companies increasingly realize that including sustainability in the businessmodel can create corporate value. We refer to the inaugural speech of Bauer (2008) for a detailed overview of this so-called socially responsible investing (SRI).

In the real estate sector, sustainability and social policies have not yet received the attention of institutional investors as comparable to other asset classes. This is surprising, as the behavior of the building sector is potentially quite important in, for example, matters of environmental sustainability. It is reported that buildings account for approximately 40 percent of the consumption of raw materials and energy. In addition, 55 percent of the wood that is not used for fuel production is consumed in construction. Overall, buildings and the associated materials produced for construction activity account for at least 30 percent of world greenhouse gas emissions (RICS, 2005). And once a building is constructed, the energy consumption associated with it continues. The impact of energy costs directly affects the bottom-line of tenants and building owners. Energy represents 30 percent of operating expenses in a typical office building, which makes it the single largest and most manageable operating expense in the provision of office space.

These magnitudes suggest that real estate can play an important role in making our societies more energy efficient. Sustainability issues in residential real estate have been previously addressed in the literature, merely in the context of energy efficiency. Quigley (1984) models energy usage as input into the production and demand functions of housing services. The derived results show that a doubling of energy prices increases housing prices by 11 to 15 percent, whereas demand for new owner-occupied housing decreases by five percent, and demand for residential energy decreases by 19 to 24 percent. The results also provide some insight in the rationale of government subsidies to induce builders and owner-occupiers to take energy saving measures. These monetary stimuli make sense if the energy prices are lower than their marginal cost to the society. In another paper on energy consumption in residential real estate, Quigley and Rubinfield (1989) model residential transaction prices as a function of housing attributes, climate characteristics and energy inputs. Consequently, the 'purchased comfort' and 'interior comfort' of a dwelling, i.e. a combination of energy inputs and structural characteristics, can be calculated. The results show how home buyers combine housing characteristics, climate conditions and energy inputs to obtain a certain level of comfort. Moreover, the results provide insight in how consumers substitute across the three inputs in order to maximize utility. A simulation of rising energy prices shows that in the short run, price elasticity of energy demand is quite low, but in the long run, households would choose newer homes, with fewer rooms.

Sustainability, or more specific, energy efficiency, has hardly been empirically addressed for commercial real estate. Although environmental awareness is growing, both real estate developers and institutional investors are understandably uncertain about how far they should go in implementing environmental investments, since the business case for the development of sustainable commercial buildings is based largely on anecdotal evidence. A report by the California Sustainable Building Task Force (2003) for example shows that average construction cost premium for green buildings is almost 2 percent, based on a sample of 33 buildings with a green label. In a more recent paper, Miller, Spivey and Florance (2008) examine rental rates and transaction prices in buildings with a green label - Energy Star or LEED - and compare these with a control sample. Their findings show that green buildings command rental premiums ranging from $\$ 2.41$ to $\$ 11.33$ per square foot over their non-green peers. Moreover, transaction prices are $\$ 61$ to $\$ 171$ higher. In a comparable research effort, Fuerst and McAllister (2008) document approximately the same results. 
Although the literature on sustainability in the built environment is taking off, credible evidence on the value case for sustainability is still lacking. This contrasts with a growing body of evidence on the profitability of incorporating eco-efficiency measures in both strategic management and investment decision-making (Margolis and Walsh, 2003). With institutional investors increasingly implementing the ESG theme across asset classes, there is a growing need for real estate research on sustainability in the property sector.

In the second part of this dissertation, we aim to fill this gap by providing the first credible evidence on the economics of building 'green'. Furthermore, we examine the corporate tenant structure in green buildings. For the investment cornmunity, it is crucial to adapt to the needs of different tenants, and to be able to identify those who are willing to pay a premium for leasing more sustainable office space. The findings and conclusions in the second part of this thesis are an important first step in providing a rationale to the societal debate on corporate social responsibility for an industry which offers potentially the most rewards from environmental awareness and enhancement.

\subsection{Outline}

This dissertation is organized in three parts. Part One - consisting of chapters 2, 3 and 4 - examines corporate governance issues in the global property market. In Part Two, which includes chapters 5 and 6 , the economics of sustainability in the commercial property sector are addressed. Part Three - chapter 7 - summarizes the main findings and implications of the dissertation.

Part One starts with chapter 2, a study on the market for corporate control in the global property sector. The notable absence of hostile takeovers in the property sector, earlier documented by Allen and Sirmans (1987) and Campbell et al. (2005) is again confirmed in our sample - out of 95 takeovers of property companies all over the world, we find that only two are hostile. To determine the ultimate effectiveness of the market for corporate control, we first study characteristics of targets and acquirers compared to a control sample, using the complete global universe of listed property companies during the most recent takeover wave $(1999-2004)$. We find that the inefficient management hypothesis holds for both REITs and non-REITs, as targets exhibit significant underperformance before takeovers. In the second part of this chapter, we investigate shareholder wealth effects following takeovers and confirm previous findings that abnormal returns for targets and bidders are distinctly different for the real estate sector. Moreover, we show that this difference not only holds for REIT-to-REIT mergers, but also for mergers of real estate firms without a REIT-status.

Chapter 3 studies the drivers of executive compensation in the listed U.K. property sector. The United Kingdom provides an excellent opportunity to analyze executive compensation due to high transparency in the different components of executive compensation. Moreover, the United Kingdom represented the largest property market without a REIT regime (until January 2007). We show that company size is the most important variable in explaining the level of executive compensation. We find that absolute and relative share performance significantly explains long-term compensation, that management style has a distinct influence on the level of executive compensation, and that using alternative monitoring mechanisms (institutional shareholders, 
debtholders, and outside directors) leads to higher levels of long-term incentives. We find only weak evidence of pay-performance sensitivity for both cash and long-term compensation. Executive shareholdings provide a much stronger link between pay and performance than does executive compensation.

In chapter 4, we examine the corporate governance structure of REITs, as they offer a natural experiment in corporate governance due to the fact that they leave little free cash flow for management, which reduces agency problems. We exploit a unique and leading corporate governance database to test whether corporate governance matters for the performance of U.S. REITs. We document for a sample including governance ratings of more than 220 REITs that firm value is significantly related to firm-level governance for RElTs with low payout ratios only. Repeating the analysis with the complete database that includes more than 5,000 companies, and a control sample of firms with high corporate real estate ratios, we find a strong and significantly positive relation between our governance index and several performance variables, indicating that the partial lack of a relation between governance and performance in the real estate sector might be explained by a REIT effect.

Part Two of this dissertation is concerned with sustainability in the real estate sector, shifting the focus to direct real estate rather than indirect (listed) property companies. Chapter 5 provides evidence on the economic value of the certification of "green buildings" in the commercial sector - value derived from impersonal market transactions rather than engineering estimates. We match publicly available information on the addresses of Energy-Star and LEED-rated office buildings to the characteristics of U.S. office buildings, their rental rates and sales prices. We analyze the micro data on the rents commanded by 694 certified green buildings and 7,489 other office buildings located within a quarter mile of the certified buildings. We also analyze micro data on the sales prices of 199 green office buildings sold between 2004 and 2007 and on the prices of 1,617 other nearby buildings. We find systematic evidence that rents for green offices are about two percent higher than rents for comparable buildings located nearby. Effective rents, i.e., rents adjusted for the occupancy levels in office buildings, are six to nine percent higher in green buildings than in comparable office buildings nearby. At prevailing capitalization rates, conversion of the average non-green rental building to an equivalent green building would add about $\$ 5.1$ million in market value. Ceteris paribus, the sales prices of green office buildings are about 16 percent higher than other nearby buildings. Conversion of the average non-green office building sold in 2004-2007 to a green building would add $\$ 5.9$ million in market value. These results are robust to the statistical models employed.

In chapter 6 , we conduct a quantitative study to explain why firms lease commercial office space in buildings with a green label - as this implies paying a rental premium. Based on a literature review, we construct a framework of drivers underlying corporate social responsibility. We formulate four propositions that explain why specific industries might be more willing to lease green. Then, we test the propositions using a sample of 11,000 unique tenants in approximately 5,000 office buildings, of which 1,200 buildings are green. We find that corporations in the oil and banking industry, as well as government-related organization, are among the most prominent green tenants. The empirical analysis shows that only government-related agencies are statistically more likely to rent green office space.

Part Three of this dissertation includes chapter 7 and provides a summary of the major findings in the five empirical chapters. Moreover, we translate these findings in more practical managerial implications. The chapter ends with limitations of this dissertation and suggestions for further research. 


\section{part one}

Corporate Governance in Global Property Markets 


\section{How Does the Market}

for Corporate Control Function for Property Companies?

This chapter is based on Eichholtz, P.M.A. and Kok, N. "How Does the Market for Corporate Control Function for Property Companies?" Journal of Real Estate Finance \& Economics, 2008, 36/2), pp. 141-63. 


\section{How Does the Market for Corporate Control Function for Property Companies?}

\subsection{Introduction}

The driving forces of the takeover market have long been subject to academic interest. Potential motives for takeovers ${ }^{3}$ include taxes, increase of market power, diversification of operations, creating synergies, undervaluation of targets and wealth transfers to stockholders from bondholders or employees (Agrawal and Jaffe, 2003). From a governance point of view, the market for corporate control is generally regarded as an important disciplinary force (Jensen, 1988): the threat of a takeover might reduce the agency problem by stimulating agents to take decisions that are in line with the principals' interest and an actual takeover provides an acquiring firm with the opportunity of restructuring an underperforming target. This is usually referred to as the inefficient management hypothesis and is regarded as a prominent motive for takeovers in the literature.

The inefficient management hypothesis has been tested from two different perspectives. The first approach measures target performance prior to the takeover announcement, using either stock returns or operating measures of performance. Regarding this approach, there is no consensus in the literature to whether the inefficient management hypothesis holds (Agrawal and Jaffe, 2003, Shleifer and Vishny, 1986). The second approach tests target and bidder performance around and after the announcement of the takeover bid. If a takeover indeed corrects failing managers, the stock return of both acquirers and targets should improve around and after the bid announcement. In line with expectations, positive total wealth effects are consistently documented, but wealth effects to acquirers are generally documented to be negative.

This chapter elaborates on the inefficient management hypothesis by focussing on the real estate sector specifically, which is of interest for several reasons. First, the real estate sector is characterized by a lack of hostile takeovers. This was first documented for a real estate takeover wave in the 1980 s by Allen and Sirmans 11987), who find that only one event could be classified as a hostile takeover. Moreover, in a follow-up study, Campbell et al. (2001) find no hostile takeovers at all in their sample, which covers the $1990-1994$ period. The absence of hostile takeovers in the property sector is contrasting to empirical evidence found for other sectors; several studies document that hostile takeovers occur frequently (Agrawal and Jaffe, 2003, Morck, Shleifer and Vishny, 1988, Servaes, 1991). This might indicate that the market for corporate control differs from other sectors and that it may not function properly for the real estate sector. We will investigate this issue further.

3 We use the terms merger, acquisition and takeover interchangeably throughout the paper. 
Secondly, the inefficient management hypothesis has only been tested partially for the real estate sector, as to our knowledge no study exists that investigates prior performance of takeover targets in the real estate sector. Moreover, wealth effects following takeovers have been studied, but the findings are different in magnitude and sign compared to other sectors (Allen and Sirmans, 1987, Campbell, et al. 2001). This yields the necessity for a detailed study of the takeover market in the real estate sector, a gap in the empirical knowledge that will be filled by this chapter.

Thirdly, corporate governance issues in the real estate sector are especially of interest, because of the experimental laboratory offered by REITs. The real estate sector might be less vulnerable to agency problems, due to the possibility for property companies in several countries to transform into a structure comparable to the US Real Estate Investment Trust (REIT). In this legal framework, up to $100 \%$ of the free cash flow is distributed to the shareholders in exchange for a $0 \%$ corporate tax rate and moreover, restrictions can be imposed on the use of leverage and the structure of the investor base. The unique institutional setting in which REITs operate leads to a situation in which the free cash flow problem is less of an issue, thereby reducing agency problems. On the other hand, the imposed dispersion of ownership might obstruct takeovers (Ghosh and Sirmans, 2003a). In our detailed study on the functioning of the real estate takeover market, we will make a comparison between takeovers of REITs and takeovers of real estate companies without a REIT-status to investigate how the REIT structure affects the inefficient management hypothesis.

Lastly, we test whether the inefficient market hypothesis holds for the real estate sector using an international sample of 95 takeovers over the $1999-2004$ period. We first analyze the financial characteristics of targets and elaborate on existing studies by also taking other variables than performance characteristics into account. Furthermore, we include an analysis on the characteristics of bidders. Finally, we compare targets, acquirers and a control sample using a multinomial logistic approach and find that, although hostile takeovers are rare in the real estate sector, the takeover market seems to work effectively as targets are mainly financially underperforming, small companies that have a low market-to-book value. Moreover, the financial underperformance of targets seems to hold for REITs as well as non-REITs.

As a second test of the inefficient market hypothesis, we perform an event study on abnormal returns surrounding the bid announcement, which shows weak but consistent results supporting the inefficient management hypothesis, because the positive total wealth effects we document indicate that shareholders perceive takeovers to be value-creating rather than value-destroying. We find evidence that shareholder returns for bidders in the real estate sector are around zero, which is relatively high compared to findings in the corporate finance literature. Abnormal returns to targets are significantly positive, although the scope is smaller compared to results previously documented in the existing finance literature. Finally, the legal structure of targets plays a distinctive role in the scope of wealth effects following takeovers.

The rest of this chapter is organized as follows. The second section provides a short literature overview in which we first discuss studies on pre-acquisition performance of targets. Secondly, we review the literature on wealth effects following takeovers. Section 2.3 presents the data and descriptive statistics. Section 2.4 discusses the methodology and results on the analysis of characteristics of targets and bidders compared to a control sample. First, pre-acquisition performance of targets is studied, followed by a univariate analysis and finally a multinomial logistic regression. In Sections 2.5 , the results on the analysis of shareholder wealth 
effects following takeovers are presented, while chapter 2 ends with a summary and discussion of conclusions in Section 2.6.

\subsection{Literature Review: the Inefficient Management Hypothesis}

\subsubsection{Pre-acquisition Performance of Targets}

The inefficient management hypothesis states that inefficient allocation of resources might lead to underperformance and therefore, takeover activity is believed to be motivated by the desire to improve the targets' performance by improving the targets' management (Agrawal and Jaffe, 2003). Evidence of the practical application of this theory is mixed and a comprehensive review is provided in the Appendix of Agrawal and Jaffe (2003).

In studies which specifically address prior stock performance of targets in mergers, the evidence for the efficient management hypothesis is not compelling, as only one study finds significantly negative abnormal return (Asquith, Bruner and Mullins, 1983) whereas seven others do not (Agrawal and Jaffe, 2003. Agrawal and Walkling, 1994, Asquith and Kim, 1982, Ellert, 1976, Langetieg, 1978, Malatesta, 1983, Mandelker, 1974). It might be expected that hostile takeovers - often tender offers - rather than friendly mergers are triggered by poor performance, but in five studies (Dodd and Ruback, 1977, Franks and Mayer, 1996, Kini, Kracaw and Mian, 2004, Martin and McConnell, 1991. Smiley, 1976) on target performance in tender offers, only Smiley finds that targets exhibit significantly negative pre-acquisition performance.

Several other studies try to explain takeover probability by using predicting models and public data, including financial performance measures. For operating measures of performance, the evidence of underperformance leading to an increased takeover probability is insignificant as documented by Palepu (1986), Song and Walkling (1993) and Berger and Ofek (1996), whereas Morck et al. (1988), Barber, Palmer and Wallace (1994), Graham, Lemmon and Wolf (2002) find that poor performance leads to a higher probability of becoming a target. With respect to stock measures of performance Palepu (1986) finds a negative relationship between prior stock performance and probability of acquisition, whereas Morck et al. (1988) document no significant influence of abnormal returns on the probability of neither hostile nor friendly acquisition.

Finally, some papers do not specifically study performance of targets, but use other measures that are related to the inefficient management hypothesis, mostly related to corporate governance, for example board composition and ownership structure (Ambrose and Megginson, 1992, Mitchell and Lehn, 1990, Morck, et al. 1988, North, 2001. Shivdasani, 1993, Song and Walkling, 1993, Weir and Laing, 2003). Although some of the studies indeed support the inefficient management hypothesis, Agrawal and Jaffe (2003) note that corporate governance variables might as well constitute direct evidence due to the correlation with firm performance.

The existing base of literature does not provide consistent evidence in favour of the efficient management hypothesis. Moreover, no specific research for the real estate sector has taken place hitherto. The first part of our analysis will therefore focus on operating and financial measures of performance of targets prior to takeover bids. Moreover, we will control for variables that might have an influence on takeover probability, such as board composition, ownership structure and asset characteristics. Finally, we broaden our analysis to the characteristics of bidders to get a complete insight in what exactly drives takeovers in the real estate sector. 


\subsubsection{Shareholder Wealth Effects Following Takeovers}

If the efficient management hypothesis holds and thus the objective of a takeover is to correct for managerial failure, we would not only expect target firms to show poor performance prior to a takeover bid, but we would also expect positive post-takeover wealth effects for bidders and targets. Hitherto, several perspectives on wealth effects following takeovers have been studied in finance literature, thereby addressing specific issues such as method of payment (Franks, Harris and Mayer, 1988, Travlos, 1987), identity of target (Chang, 1998), methodology (Asquith, et al. 1983), firm size (Moeller, Schlingemann and Stulz, 2004), and the impact of sectorspecific characteristics (Allen and Sirmans, 1987, Subrahmanyam and Rangan, 1997).

In general, the inefficient management hypothesis is supported by the consistently significant and positive cumulative abnormal returns (CAR) documented for targets. For example, Servaes (1991) documents a CAR of $20.5 \%$ for all-equity acquisitions and a CAR of $26.7 \%$ for cash bidders, Dodd (1980) reports a $13.4 \%$ CAR for a sample of takeover targets including all methods of payment. For the real estate sector, Mclntosh et al. (1989) report lower gains to bidding firms with a CAR of $6.2 \%$. Campbell et al. (2001) also find positive (3.0\%), but relatively low returns to target shareholders. Campbell (2002) explains these findings by the fact that the market for corporate control is not very powerful in the listed real estate sector, as hostile takeovers are completely absent. Moreover, Sirmans (1997) suggests that corporate governance structures might be less efficient in REITs due to institutional restrictions, leading to advantages of synergy in mergers to flow to managers rather than shareholders. These findings indicate that the inefficient management hypothesis might hold to a lesser extent for the real estate sector than for other sectors.

If bidders would act in line with the inefficient management hypothesis and only acquire underperforming companies, the abnormal return for bidders following acquisition announcements is expected to be positive as well. However, there is a consensus in the literature that bidders hardly show significantly positive abnormal returns. Within others, Asquith et al. (1983) find cumulative abnormal returns (CARs) of $-2.4 \%$, and Travlos (1987) documents a CAR of $-1.7 \%$. Moreover, shareholder wealth effects accruing to bidders are negatively influenced by stock as a method of payment, which is often explained by the information signalling theory of Myers and Majluf (1984). There are some exceptions to the negative effect on shareholder wealth of acquiring companies following stock bids; Chang (1998) shows that in takeovers of private firms, stock as a method of payment leads to positive acquirer returns. This finding is explained by the positive monitoring effect due to creation of blockholders in the merged entity and the positive signal of the willingness of well-informed investors to take a substantial position in an acquiring firm. The second exception to negative returns for stock-bidders is a study by Allen and Sirmans (1987), who find nonnegative performance effects for bidders if stock is used as a method of payment in takeovers. This finding is explained by the reduced cash-generating ability of REITs.

In a recent study, Campbell et al. (2001) extend the studies of Chang (1998) and Allen and Sirmans (1987), by exploring the influence of method of payment in both public-public and public-private takeovers in the REIT-sector. In contrast to Allen and Sirmans (1987), they find that stock acquisitions in public-to-public REIT mergers lead to slightly negative results, although the scope of these results is smaller than found by other studies. Consistent with Chang (1998), they find a positive shareholder wealth effect following stock bids on private targets. 
The real estate sector with its unique institutional environment has yielded inconsistent results with respect to shareholder wealth effects following takeovers. Therefore, we use a global sample of takeovers including the United States, but also other important real estate markets, such as the United Kingdom, the Netherlands and Australia. This sample allows us to determine whether the distinct abnormal returns documented for the real estate sector hitherto are REIT or rather real estate specific.

\subsection{Data}

\subsubsection{Data and Methodology}

Our initial sample consists of 145 takeovers during the $1999-2004$ period. These were identified using data obtained from Global Property Research (GPR) and include all takeovers involving a public target. ${ }^{4}$ Contrasting Chang (1998) and Campbell et al. (2001) we do not include takeovers of privately held companies. This is mainly because data on takeovers of private real estate targets is hardly available internationally, which also holds for financial and other information regarding private firms. ${ }^{5}$

Transactions on which no financial information could be found or that appeared to be cancelled or still pending were deleted from the sample. Moreover, the inclusion of small and less liquid stock markets in our analyses might introduce noise rather than improve the significance of our findings. ${ }^{.}$Therefore, we use a reduced sample throughout the chapter. This sample contains 95 takeovers - of which 51 have a public acquirer. Countries included are: United States, Canada, United Kingdom, Australia, Sweden and the Netherlands.

In order to get a better insight in the drivers of mergers and acquisitions, we match the targets and acquirers to a control firm using a temporal matching approach following Ambrose (1990). The control sample consists of all listed real estate firms in the selected countries, with a minimal market capitalization of $\$ 50 \mathrm{~m} / \mathrm{n}$. ${ }^{7}$ From this sample firms are excluded if (1) they are involved in mergers and acquisitions during the sample period, (2) they are not continuously listed, or (3) the required data is not available. This leads to a control sample of 103 firms, allowing a control firm to be in the sample more than once.

Following Franks and Mayer (1996), we examine how long-run pre-acquisition stock performance differs between targets and non-targets. Moreover, we investigate the impact of performance on the likelihood of being involved in a takeover, either as a target or as an acquirer, while controlling for the impact of other variables. We use a selection of financial characteristics based on studies described in the literature review, in particular (Palepu, 1986). These variables include leverage, valuation, size, dividend yield, cash holdings and seiling expenditures. Moreover, we include governance and asset characteristics as control variables, where selection of variables is based on existing studies as well. More specifically, we include managerial ownership (North, 2001, Song and Walkling, 1993), block ownership (Shleifer and Vishny, 1986), independence of the board (Shivdasani, 1993, Weir,

4 The sample includes real estate operating companies and REITs, but excludes pure construction and development companies.

5 We recognize the potential sample bias of not including transactions including private targets, but as we are interested in stock and operating performance of targets, private targets are less of interest due to non-availability of this performance data

6 We repeat our analyses using both the complete sample and the sample that includes a selection of markats only. The results indeed seem to benefit from the exclusion of small markets.

7 The control sample is provided by GPR and does not include pure construction and development companies, 
1997) and portfolio characteristics (Campbell, et al. 2001). All variables and their respective sources are listed in Appendix 2.A.

The required financial data are obtained from Datastream, Worldscope and Thomson Research, whereas details on portfolio composition and ownership structure are hand-collected from proxy statements, annual reports and GPR Handbooks. In line with Ambrose (1990), data is collected around an 'information date', which is assumed to be exactly half a year before the announcement date $t$ of a merger or acquisition. In order to correct for extreme observations, values for daily measured variables are calculated over a 130-trading day period around the information date and yearly measured variables are calculated as an average value of the last three years before the announcement date. Stock performance prior to takeovers is measured on a monthly basis for various intervals.

\subsubsection{Descriptive Statistics}

A first analysis of the data reveals the striking finding that our sample includes only two hostile takeovers. This number is relatively small in a sample of 95 takeovers during the $1999-2004$ time period, but is consistent with earlier findings for the real estate sector as documented by Allen and Sirmans (1987). Campbell et al. (2001) and Campbell (2002). Explanations for the absence of hostile takeovers in the real estate sector can be twofold: there is a reduced need for incentive and monitoring mechanisms in the restricted REIT environment, or, the restricted investor environment of REITs obstructs hostile takeovers (Ghosh and Sirmans, 2003a). However, our sample does not support either of these arguments, since hostile takeovers are also absent in markets without the REIT structure. The lack of hostile takeovers therefore seems to be a real estate issue rather than a REIT issue. Further discussion of this finding is provided in Section 2.6.

Table 2.1 shows that the sample contains transactions from 6 different countries, of which the majority has taken place in the United States, the United Kingdom and Australia. Furthermore, almost half of the mergers and acquisitions involve private acquirers, which is due to the fact that the real estate sector still consists of a larger non-listed than listed sector, especially in Europe. Taking a closer look at the private bidders in Europe, we find a high number of management buyouts in the United Kingdom, which might be explained by the discounts to NAV that are frequently observed for U.K. listed property companies over the sample period (Brounen and ter Laak, 2005).

Due to the small number of observations, our sample does not include takeovers taking place in the relatively large listed real estate markets of Asia (eg. Japan, Hong Kong, South Korea). The low takeover activity may well be explained by the institutional structure in these countries: most of the property companies are part of a larger conglomerate (eg. keiretsu or chaebol), which usually owns a majority of the shares.

Only ten deals in our sample are cross-border. The reason for international diversification still taking place on a relatively small scale might be the underperformance real estate firms investing internationally as compared to firms investing locally (Eichholtz, Koedijk and Schweitzer, 2001). Eight out of ten international acquisitions involve an acquirer or target from continental Europe, mostly originating from the Netherlands. The relatively small size of listed real estate markets in continental Europe compared to the United States and the United Kingdom yields the necessity for European property companies for cross-border acquisitions. Moreover, there is great potential for deals within the European Union due to increasing integration of the fragmented national economies into one single market. 
The cyclical nature of merger and acquisition activity in the real estate sector as described by Campbell (2002) is reflected in Table 2.2, which shows a clear peak in acquisition announcements for the years 2000 and 2001, in which almost two-third of the acquisitions took place. This could be related to the bearish sentiment on the stock market at those times, which lead to low market-to-book values of property companies. With respect to possible seasonal effects, we find no distinct pattern in the distribution over the quarters. Finally, Figure 2.1 provides insight in the time to completion of takeovers in the sample. The time to completion reflects the period between announcement of the takeover and final acquisition of the shares of the target. As our sample almost completely exists of friendly takeovers, the average completion time is short, about 3.5 months, with a majority of the deals closed in less than half a year, which is in line with findings by Allen and Sirmans (1987). Further analysis of the relationship between method of payment and the time to completion reveals that a cash bid leads to a shorter time to completion than alternative methods of payment.

Table 2.1

Characteristics Takeover Sample

$(1999-2004)$

\begin{tabular}{|c|c|c|c|c|c|c|c|c|}
\hline \multirow[t]{2}{*}{$\overline{\text { Country }}$} & \multirow{2}{*}{$\begin{array}{c}\text { Universe } \\
\# \\
\end{array}$} & \multirow{2}{*}{$\begin{array}{c}\text { Targets } \\
\# \\
\end{array}$} & \multirow{2}{*}{$\begin{array}{c}\text { Acquirers } \\
\text { Listed }\end{array}$} & \multicolumn{3}{|c|}{ Method of payment } & \multicolumn{2}{|c|}{ Deal Value (\$mln) } \\
\hline & & & & Cash & Stock & Mix & Mean & SD \\
\hline \multicolumn{9}{|l|}{ North America } \\
\hline United States & 139 & 31 & 20 & 15 & 12 & 4 & 822.3 & 802.7 \\
\hline Canada & 22 & 6 & 2 & 4 & 1 & 1 & 341.2 & 304.6 \\
\hline \multicolumn{9}{|l|}{ Europe } \\
\hline Netherlands & 9 & 6 & 4 & 4 & 2 & 0 & 949.2 & 774.9 \\
\hline Sweden & 13 & 9 & 2 & 9 & 0 & 0 & 401.7 & 402.0 \\
\hline United Kingdom & 41 & 29 & 4 & 25 & 2 & 2 & 933.1 & 1747.1 \\
\hline \multicolumn{9}{|l|}{ Asia (Pacific) } \\
\hline Australia & 26 & 14 & 19 & 5 & 5 & 4 & 563.5 & 453.9 \\
\hline Total & 250 & 95 & 51 & 62 & 22 & 11 & 908.1 & 1087.8 \\
\hline
\end{tabular}

Notes: Table 2.1 provides descriptive statistics on the takeovers in our sample. We match all deals in the different countries to the complete universe of property companies in every country (market cap $>\$ 50 \mathrm{mln}$, source: GPR) to get insight in the relative national takeover activity. All targets are publicly listed, for acquirers the number of listed firms is provided. We distinguish three methods of payment: cash, stock and mixed. Deal value denotes the average deal value in US\$m/n. 
Corporate Governance and Sustainability in Global Property Markets

Table 2.2

Distribution of Takeovers over the Sample Period

(1999-2004)

\begin{tabular}{lrc}
\hline & \multicolumn{2}{c}{ Deals } \\
Year & $\#$ & $\%$ \\
\hline 1999 & 8 & 8.4 \\
2000 & 33 & 34.7 \\
2001 & 24 & 25.3 \\
2002 & 14 & 14.7 \\
2003 & 13 & 13.7 \\
2004 & 3 & 3.16 \\
& & \\
Total & 95 & 100 \\
\hline
\end{tabular}

Notes: Table 2.2 shows the distribution of takeover announcements over the sample period in absolute and relative numbers.

Figure 2.1

Distribution of Time to Completion

(in months)

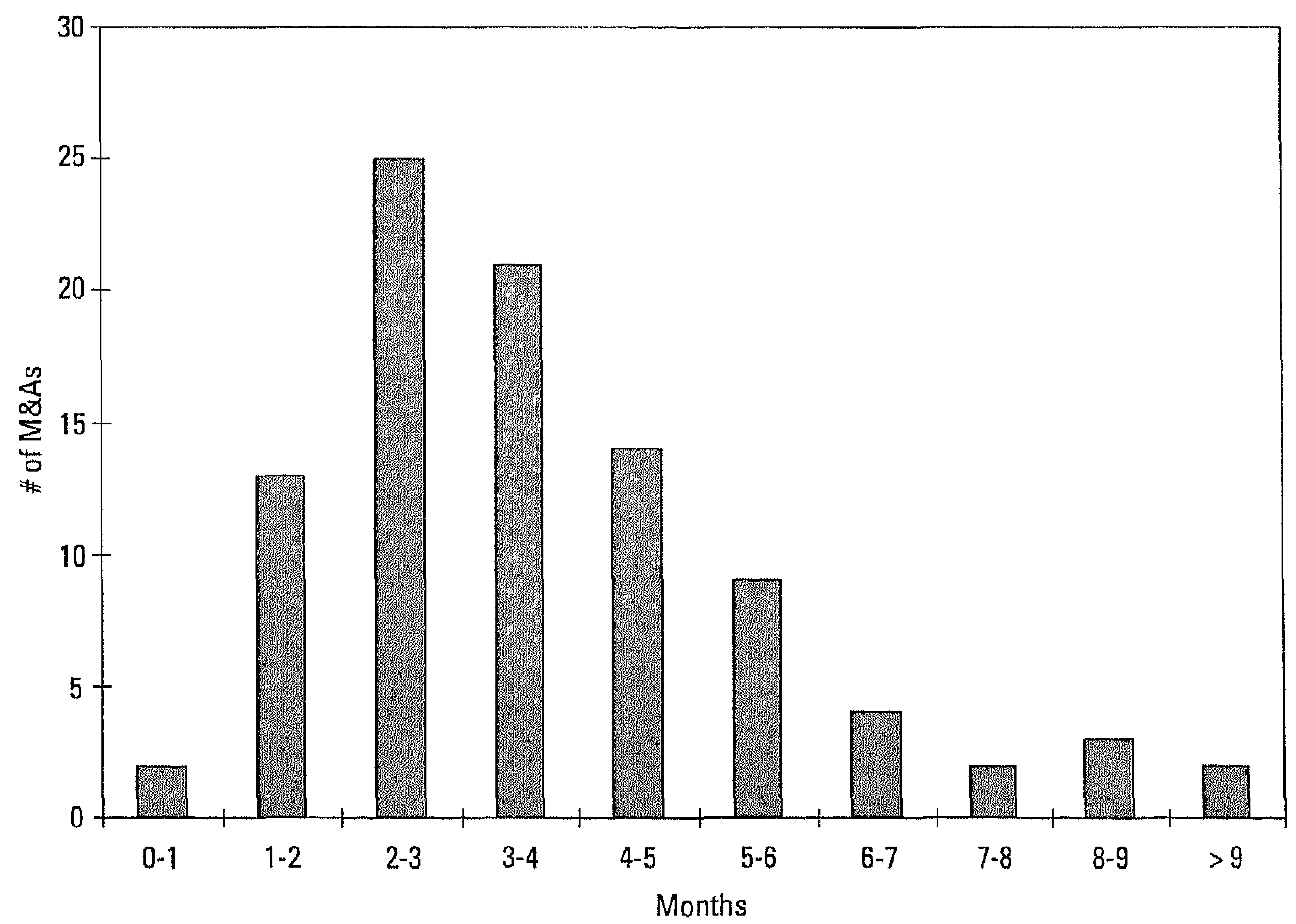

Notes: Figure 2.1 shows the average time to completion for takeovers in our sample. Completion time is calculated as number of months between the announcement date and the final acquisitions date of all target shares.

22 


\subsection{Drivers of the Takeover Market}

\subsubsection{Pre-Acquisition Performance}

If the inefficient management hypothesis holds and the takeover market functions effectively, we would expect poor performance of targets prior to the takeover announcement. Therefore, we measure long-run pre-acquisition performance across all targets using a market model, following Franks and Mayer (1996). ${ }^{B}$ The cumulative abnormal returns (CARs) are calculated for various time intervals, which all stop at month $t=3$ to avoid noise due to information leakage in the months close to the announcement date. Furthermore, we match the sample of targets to the equivalent part of the control sample. Panel A of Table 2.3 shows the results.

We find support for the inefficient management hypothesis in the short run, as abnormal performance of the targets is negative in the short run and significantly lower than performance of the control sample. Although targets underperform the control sample for all intervals in the long run, the significance disappears. Our results contrast previous literature (e.g. Agrawal and Jaffe, 2003, Franks and Mayer, 1996), as the underperformance of targets in the short run has not been documented before. To test for robustness and to get a better insight in this new finding, we make a distinction between performance of targets in REIT-REIT takeovers and performance of targets in non-REIT takeovers. We find that non-REIT targets exhibit significant underperformance in the short run and strongly varying performance in the long run. REIT targets underperform the control sample in the short run as well, but show a more stable performance over the long run. These results indicate that underperformance of real estate targets prior to takeovers does not depend on their legal structure. ${ }^{9}$

In Panel B of Table 2.3, we provide a first analysis of target performance around the bid announcement and find that abnormal returns over the announcement period are significantly positive, which is in line with existing literature. We will analyze post-announcement stock performance in more detail in Section 2.5 .

8 As our sample includes targets from 6 countries, the use of a single market index would lead to estimation errors. Therefore, we match the market index to the origin of the target using GPR Local Indices (available on a monthly basis).

9 In our comparison of REIT vs. non-REIT takeovers, we assume that potential differences are driven by the REIT-structure. However, differences between the two groups might as well be attributed to country-specific characteristics, as the non-REIT sample is dominated by UK firms. The limited number of non-REITs in the US restricts in-country comparison between REITs and non-REITs, but the recent adoption of the REIT structure in several Asian and European countries may enable future analysis on the impact of the REIT structure on corporate governance issues such as the market for corporate control. 
Corporate Governance and Sustainability in Global Property Markets

Table 2.3

Pre-Acquisition Performance of Targets

(t-statistics in parentheses)

\begin{tabular}{|c|c|c|c|c|c|c|c|c|}
\hline \multicolumn{9}{|c|}{ Months Around } \\
\hline \multicolumn{2}{|c|}{ Announcement } & \multicolumn{3}{|c|}{ Targets } & \multicolumn{3}{|c|}{ Control sample } & Difference \\
\hline \multicolumn{9}{|c|}{ Panel A. Long-Run Pre-Acquisition Performance } \\
\hline$t_{1}$ & $\mathrm{t}_{2}$ & $\operatorname{CAR}(\%)$ & $t$-stat & $n$ & $\operatorname{CAR}(\%)$ & $t$-stat & $n$ & $t$-stat \\
\hline-3 & -12 & -3.24 & $(-1.35)$ & 95 & 3.05 & $(1.67)^{*}$ & 101 & $(2.08)^{* *}$ \\
\hline-3 & -24 & -0.46 & $(-0.12)$ & 87 & 6.54 & $(2.01)^{*}$ & 98 & $(1.41)$ \\
\hline-3 & -36 & 6.62 & $(1.31)$ & 79 & 13.49 & $(3.31)^{* *}$ & 91 & $(1.06)$ \\
\hline-3 & -48 & 7.38 & $(1.52)$ & 68 & 16.86 & $(3.18)^{* *}$ & 83 & $(1.32)$ \\
\hline-3 & -60 & 11.49 & $(1.98)^{*}$ & 63 & 22.22 & $(3.43)^{* *}$ & 77 & $(1.23)$ \\
\hline \multicolumn{9}{|c|}{ Panel B. Performance Around Acquisition } \\
\hline$t_{1}$ & $\mathrm{t}_{2}$ & $\operatorname{CAR}(\%)$ & $t$-stat & $n$ & CAR $(\%)$ & $t$-stat & $n$ & $t$-stat \\
\hline-1 & & 1.24 & $(1.25)$ & 95 & 1.60 & $(1.84)^{*}$ & 103 & $(-0.55)$ \\
\hline+1 & & 9.26 & $(10.04)^{* *}$ & 95 & -0.45 & $(-0.69)$ & 103 & $(8.63)^{* *}$ \\
\hline-1 & 1 & 10.50 & $(7.47)^{* *}$ & 95 & 1.82 & $(1.87)^{*}$ & 103 & $(5.47)^{* *}$ \\
\hline
\end{tabular}

Notes: Panel A of Table 2.3 presents the pre-acquisition performance of targets and the control sample in the long run. CAR is the Cumulated Abnormal Return over the interval as stated in column 1, where abnormal returns are calculated using a market model based on Franks and Maver (1996). Companies are only included in the analysis if they data was available for the specific time interval. The significance of the difference between performance of targets and the control sample is tested using a t-test assuming unequal variances. Panel B provides results on performance of targets and control sample around the bid announcement.

$t$-statistics im parentheses. Significance at the 0.10 and 0.05 levels is indicated by ${ }^{*}$ and ${ }^{*}$ " respectively.

\subsubsection{Univariate Analyses}

After the first test of the inefficient management hypothesis, the next step is to investigate how targets and bidders differ from the control sample, by comparing financial characteristics, governance structure and portfolio characteristics. This preliminary analysis is performed by applying a sample $t$-test assuming equal variances, to compute whether the mean values of the variables differ significantly between the three groups. ${ }^{10}$

Regarding operating measures of performance, the results in Table 2.4 show that the return on assets and return on equity for targets is significantly lower as compared to bidders and the control sample. This again confirms the inefficient management hypothesis and expectations that acquiring firms are better able to generate revenue with their assets. Our results are in line with the previous analysis on stock performance of targets, but contrast existing literature, which does not document operating underperformance of targets (Agrawal and Walkling, 1994, Song and Walkling, 1993). Targets pay out less dividends than firms in the control sample, which might indicate that targets either have less cash available for distribution, for example due to bad performance, or they retain cash rather than paying out dividends, which would be line with Jensen's free cash flow theorem (Jensen,

10 We stress that the means we compute are only meant to be suggestive, because we do not account for important differences between firms in the calculations. Therefore, some of the correlations might be spurious. Moreover, we do not make a distinction between REIT mergers and non-REIT mergers. We will deal with these issues in the logistic regression and assume the results presented next to be indicators of causal relationships between the variables and takeover probability. 
1986). Furthermore, the variable on financial structure (leverage) indicates that targets are significantly more levered than non-targets and bidders. This result is in line with previous real estate research (Ambrose, 1990, Campbell, et al. 2001), and consistent with the synergy theory, which suggests that bidders prefer to acquire companies with a different financial structure. Moreover, the indebtness of targets combined with evidence on underperformance and low dividend yield, suggests that takeover targets are in a weak financial position.

The low beta for targets, bidders and the control sample suggests that real estate companies are less sensitive to market movements than firms in other sectors, with bidding firms even less risky than target firms. Furthermore, the average size of bidders is almost three times as large as the average size of the targets and control firms. This is in line with expectations that large companies have more market power to engage in acquisitions and are better able to integrate acquired assets in their operations. We compare our average target size $(\$ 554 \mathrm{~m})$ to other studies and find that targets in our sample are slightly smaller as compared to both other real estate studies (Campbell, et al. 2001: $\$ 650 \mathrm{mln}$.) and more general takeover studies (Mikkelson and Partch, 1989: $\$ 787 \mathrm{mln}$., Song and Walkling, 1993: $\$ 727 \mathrm{mln}$.). This is probably due to the inclusion of European companies in our sample, which generally have a smaller size. Finally, the low market-to-book value frequently observed for listed property companies is again documented in our descriptive statistics, which indicate that real estate targets trade at a small discount on average.

Besides financial characteristics, we include control variables on corporate governance characteristics as the lack of hostile takeovers in the real estate sector may enhance the need for alternative governance mechanisms (Whidbee, 1997). First, the percentage of shares in the hands of the three largest shareholders is significantly higher for targets, which is in line with Shivdasani (1993), who finds that large shareholders play an active role as a monitoring mechanism by facilitating takeovers. Targets have a significantly lower percentage of nonexecutive directors on the board as compared to non-targets, which provides support for the hypothesis that target firms have a weaker internal governance structure. Finally, the results show that targets are more often externally managed than control firms and bidders. This is in line with Ambrose and Linneman (2001), who find that externally managed REITs are less competitive than internally managed REITs.

Lastly, the descriptive statistics show that portfolio characteristics differ significantly between targets, bidders and the control sample. Bidders are more often international companies than targets or control firms. This suggests that the local knowledge that is required for cross-border investments makes the acquisition of a foreign company a useful tool. With respect to the portfolio of bidders and targets, the results show that takeover targets are mostly real estate companies with a diversified portfolio, involved in development activities, which is in line with expectations, as diversification of operations rather than focussing on a single asset or activity is often associated with underperformance. Acquirers seem to have an investment focus on retail and office property. 
Corporate Governance and Sustainability in Global Property Markets

Table 2.4

Descriptive Statistics

Targets, Bidders and the Control Sample

\begin{tabular}{|c|c|c|c|c|c|c|c|c|c|}
\hline \multirow[t]{2}{*}{ Variables } & \multicolumn{2}{|c|}{ Control Sample } & \multicolumn{2}{|c|}{ Targets } & \multicolumn{2}{|c|}{ Acquirers } & \multicolumn{3}{|c|}{$t$-statistic } \\
\hline & Mean & SD & Mean & SD & Mean & SD & $\begin{array}{c}\text { Control } \\
\text { Target }\end{array}$ & $\begin{array}{c}\text { Target } \\
\text { Acquirer }\end{array}$ & $\begin{array}{l}\text { Control } \\
\text { Acquirer }\end{array}$ \\
\hline \multicolumn{10}{|l|}{ Financial Characteristics } \\
\hline Stock Performance & 3.05 & 18.25 & -3.24 & 22.48 & 4.34 & 10.76 & $2.08 * *$ & $-2.61 * *$ & -0.53 \\
\hline Return on Assets & 7.06 & 2.93 & 6.01 & 3.05 & 7.69 & 3.83 & $2.41^{* * *}$ & $-2.60 * *$ & -1.00 \\
\hline Return on Equity & 10.27 & 7.89 & 7.66 & 8.83 & 10.71 & 6.87 & $2.11^{* *}$ & $-2.21 * *$ & -0.34 \\
\hline Funds from Operations & s $\quad 0.05$ & 0.03 & 0.04 & 0.03 & 0.05 & 0.06 & $2.76^{* *}$ & -0.71 & 0.59 \\
\hline EPS Growth & 0.31 & 0.70 & 0.27 & 0.66 & 0.39 & 0.65 & 0.38 & -0.94 & -0.59 \\
\hline Dividend Yield & 7.29 & 4.18 & 5.40 & 3.43 & 5.89 & 3.16 & $3.44 * *$ & -0.85 & $2.29 * *$ \\
\hline Selling Expenditures & 1.17 & 0.02 & 1.15 & 0.02 & 1.11 & 0.02 & 0.04 & 0.12 & 0.18 \\
\hline Cash Holdings & 3.60 & 4.80 & 2.75 & 3.86 & 2.88 & 4.88 & 1.34 & -0.16 & 0.83 \\
\hline Leverage & 1.13 & 0.76 & 1.26 & 1.20 & 0.77 & 0.77 & -0.88 & $2.91^{* *}$ & $2.68^{* * *}$ \\
\hline Beta & 0.45 & 0.33 & 0.39 & 0.20 & 0.29 & 0.21 & 1.42 & $2.67^{* *}$ & $3.51^{* *}$ \\
\hline Market Value (\$mln.) & 552.85 & 567.38 & 553.72 & 736.21 & 1599.25 & 1952.61 & 1.17 & $-4.63^{* *}$ & $-3.94^{* *}$ \\
\hline Market-to-Book Value & 1.24 & 0.92 & 0.97 & 1.08 & 1.10 & 0.65 & $1.90^{*}$ & -0.88 & 1.14 \\
\hline \multicolumn{10}{|c|}{ Governance Characteristics } \\
\hline Blockholdings & 0.29 & 0.18 & 0.36 & 0.20 & 0.31 & 0.21 & $-2.37^{* *}$ & 1.35 & -0.46 \\
\hline Insider Holdings & 0.28 & 1.42 & 0.09 & 0.14 & 0.11 & 0.17 & 1.35 & -0.62 & 1.20 \\
\hline$\%$ Non-executives & 0.48 & 0.13 & 0.41 & 0.27 & 0.60 & 0.19 & $1.86^{*}$ & $-3.87^{* *}$ & $-3.15^{* *}$ \\
\hline In-House Management & 0.88 & 0.32 & 0.78 & 0.42 & 0.88 & 0.33 & $1.96 * *$ & $-1.65^{*}$ & 0.02 \\
\hline Liquidity & 0.55 & 1.34 & 0.99 & 2.38 & 0.51 & 0.60 & -1.59 & $1.85^{*}$ & 0.25 \\
\hline \multicolumn{10}{|l|}{ Portfolio Characteristics } \\
\hline Office & 0.10 & 0.30 & 0.16 & 0.37 & 0.20 & 0.40 & -0.57 & -1.28 & -1.56 \\
\hline Retail & 0.22 & 0.42 & 0.26 & 0.44 & 0.47 & 0.50 & $-2.47^{* *}$ & $-3.02^{* *}$ & -1.28 \\
\hline Residential & 0.17 & 0.38 & 0.08 & 0.28 & 0.10 & 0.30 & $1.92^{*}$ & -0.27 & 1.36 \\
\hline Diversified & 0.26 & 0.44 & 0.36 & 0.48 & 0.24 & 0.43 & -1.45 & 1.58 & 0.36 \\
\hline International & 0.09 & 0.28 & 0.12 & 0.32 & 0.22 & 0.42 & -0.66 & -1.49 & $1.99 * *$ \\
\hline Development & 0.14 & 0.34 & 0.74 & 0.44 & 0.18 & 0.39 & $-10.60^{* *}$ & $7.95 * *$ & -0.64 \\
\hline
\end{tabular}

Notes: In Table 2.4, descriptive statistics and the preliminary results of the comparison between targets, acquirers and control group are provided. Absolute values of variables are reported in nominal dollars. The last columns show the t-statistics of the paired sample t-test, assuming unequal variances. The definitions of all variables are provided in Appendix 2.A. Significance at the 0.10 and 0.05 levels is indicated by ${ }^{*}$ and ${ }^{* *}$ respectively. 


\subsubsection{Multivariate Results}

In order to estimate the joint impact of the previously discussed variables on the probability of a takeover attempt, we use a multinomial logistic regression model. We follow a broad stream of literature by comparing characteristics of acquired firms to a sample of control firms, and moreover, we extend the traditional methodology (Ambrose, 1990, Barnes, 1999, Dietrich and Sorensen, 1984, Palepu, 1986) by including bidders. To solve the problem of multicollinearity, we perform a stepwise regression of correlated variables and use the residuals in the multinomial analysis. To interpret the results correctly, we should point out that the focus of interest of our study is the significance of the estimated coefficients of the variables and not the predictive ability of the model (Palepu, 1986). Therefore, the coefficients do not have economic significance except for their sign.

Table 2.5 presents the logistic regression results. We confirm previous findings that, in line with the inefficient management hypothesis, weak operating and stock performance of real estate companies are positively related to takeover likelihood. The significantly negative coefficients for both operating and stock performance are not consistently documented in the corporate finance literature. For bidders, size is positively related to the probability of being an acquirer, indicating that large firms may have efficiencies and resources that make them more likely to acquire other firms (Trahan, 1993).

To check for robustness of the results and to account for the different legal structure of REITs compared to non-REITs, we repeat the analysis for REIT-REIT takeovers and non-REIT takeovers separately. "In general, our findings are similar to the results reported in Table 2.5, and most importantly, the repeated analysis confirms that the financial performance of targets in both samples is significantly negatively related to the takeover probability. Therefore, we confirm our previous findings that the inefficient management holds for REIT takeovers as well as non-REIT takeovers. One main difference is that low cash holdings lead to an increased takeover probability in REIT takeovers, which is not documented for non-REIT mergers. As REITs face the obligatory payout of cash flows, cash-trapped firms cannot easily solve financial problems and are therefore, combined with poor performance, more vulnerable to takeovers.

The signs of the corporate governance variables mainly confirm the results of the univariate analysis. For targets, the variable on insider holdings is now significantly negative, which suggests that increased managerial stockholdings deter takeovers. This might indicate that large inside shareholdings entrench managers rather than reduce the agency gap (North, 2001. Song and Walkling, 1993). This adds to earlier evidence by Ghosh and Sirmans (2003a), who partially explain the absence of hostile takeovers for RElTs by the negative effects of larger insider shareholdings. The presence of large blockholders increases the likelihood of becoming a takeover target, which suggests that large shareholders are effective monitoring mechanisms (North, 2001. Shivdasani, 1993). Furthermore, we find that property companies with an independent board have an increased likelihood to be bidders in takeovers.

We repeat the multinomial regression analysis for REIT takeovers and non-REIT takeovers separately and find that the relationship between governance and takeover likelihood is different for REIT targets as compared to non-REIT targets, whereas for bidders this relationship is similar for REITs and non-REITs. First, we documented previously that the presence of large blockholders increases the takeover likelihood for targets, but this result

11 For reasons of space, results are not reported, but these are available upon request. 
seems to be driven by the REITs in our sample. This is counterintuitive, as it is often argued that the 5-50 rule imposed on REITs limits the creation of large shareholders and thus hinders hostile takeovers (Ghosh and Sirmans, 2003a). However, our result is in line with Ling and Ryngaert (1997), who state that larger blocks of shares held by outsiders might facilitate takeovers, both because of lower transaction costs and by reducing free-rider problems by small shareholders. Second, we find evidence for REITs that a relatively low number of non-executives on the board increase the takeover likelihood, which is consistent with Weir (1997) and North (2001). They document that non-executives are only weakly represented on the boards of targets, potentially leading to weaker boards and thus less efficient monitoring. Third, the negative sign for insider shareholdings is documented for REIT takeovers as well as non-REITs takeovers.

Finally, the results on portfolio characteristics reveal that targets and bidders are only slightly different from the control sample. Property companies with operations involving development activities face an increased takeover likelihood. Furthermore, the coefficient on the market-to-book value is significantly negative for targets. This result is not surprising and indicates that the market-to-book value is a driver of takeovers within the real estate sector, even though there may be large cross-country differences and variations over time. Real estate companies with a focus on retail and office property have an increased likelihood to be bidders, which is in line with anecdotal evidence that retail mergers are prevailing in the United States.

We again compare between REIT takeovers and non-REIT takeovers and find that targets in non-REIT mergers have a significantly negative coefficient for the market-to-book value, whereas this result does not hold for REITs. This difference might be due to the transparency of REITs as compared to non-REITs, which leads to less information asymmetry between firms and shareholders. Therefore, the market is able to price REITs more accurately than non-REITs.

The analysis of the characteristics of bidders and targets in real estate takeovers has revealed interesting results, which have not been documented for the real estate sector before. Although the consistently documented absence of hostile takeovers in the real estate sector lead to expectations that the market for corporate control does not work properly for the property sector, our results confirm the inefficient management hypothesis: targets in the real estate takeover market are underperforming firms. This suggests that the market for corporate control is effective in the real estate sector, even without the threat of hostile takeovers. 
Table 2.5

Regression Results Multinomial Logistic Regression

(t-statistics in parentheses)

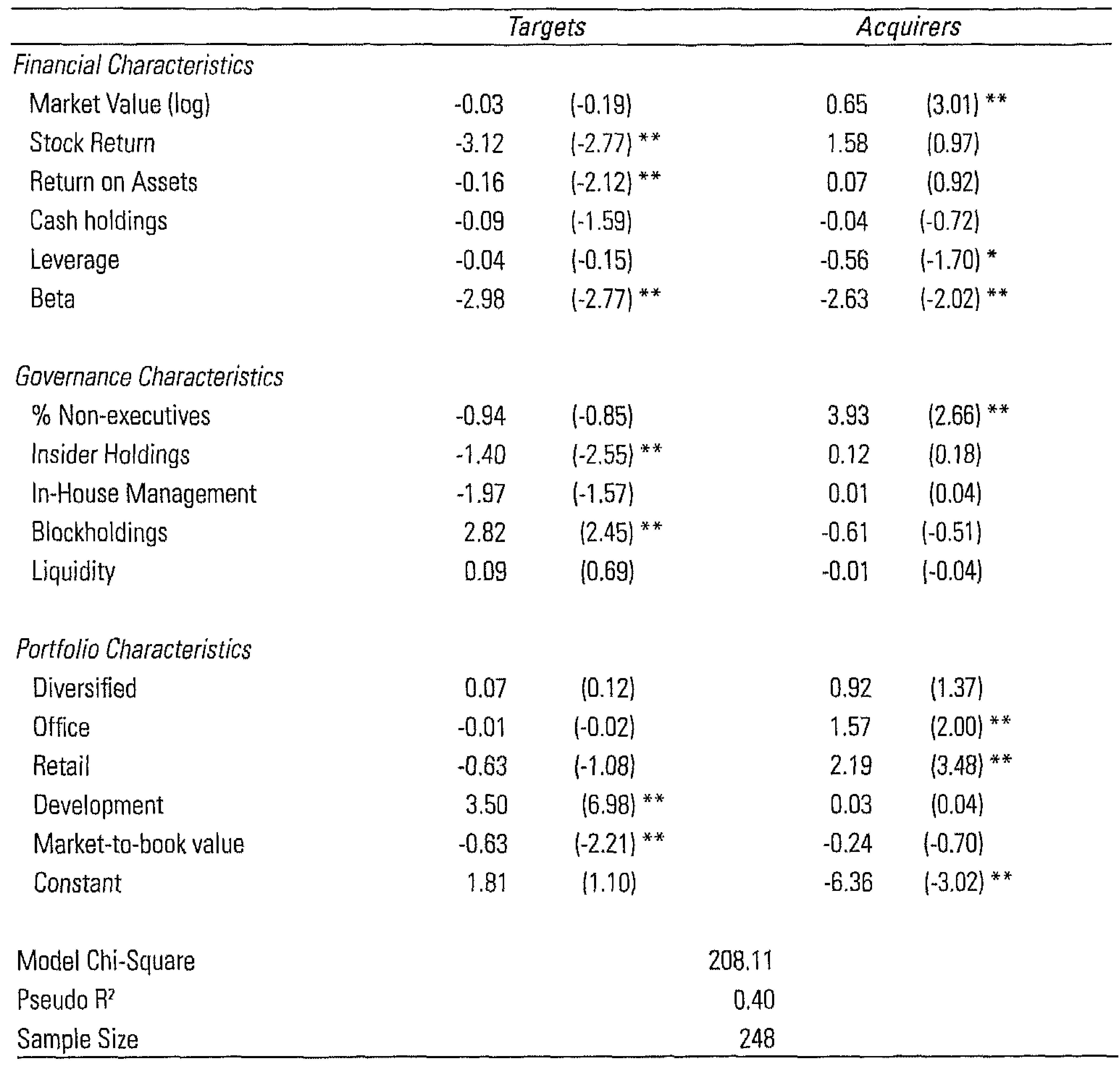

Notes: Table 2.5 shows the results for the multinomial logistic regression. Column 2 includes the regression results for targets, whereas column 3 includes the regression results for acquirers. The pseudo $R^{2}$ is the analogue of the $R^{2}$ in the normal limear regression model. The chi-square tests the null hypothesis that all parameters in the model are zero and is the equivalent of the F-test in the normal regression model. The null-hypothesis is rejected in all models. $t$-statistics in parentheses. Significance at the 0.10 and 0.05 levels is indicated by ${ }^{*}$ and ${ }^{* *}$ respectively.

\subsection{Wealth Effects Following Takeovers}

The former section provided insight in the underlying drivers of real estate takeovers, thereby focussing on pre-acquisition characteristics of targets and bidders to get an insight in the effectiveness of the market for corporate control in the real estate sector. This section elaborates on the previous section by studying the wealth 
effects surrounding the announcement of a takeover bid. Following the inefficient management hypothesis, the takeover of underperforming targets should lead to positive wealth effects for both targets and bidders. We will start with a short discussion of methodological issues; thereafter the event study results are presented.

\subsubsection{Methodology}

The impact of acquisitions on the shareholder wealth of acquirers and targets can be determined using several event study methods, among which the OLS market model and the comparison period approach (Brown and Warner, 1980). Although the OLS market model has is used in comparable studies, for example Chang (1998) and Campbell et al. (2001), our sample seems to be better suited to the comparison period approach. The acquisitions in our sample take place in several different countries, which leads to difficulties in using a single market index. Moreover, the use of several different market indices for the various markets leads to an estimation error, because the disturbance term is affected by other factors in addition to the announcements under study, such as macro-economic movements, which might differ significantly across countries. Another issue is the relative illiquidity of a substantial part of the stocks in our sample in comparison to the matched market index, leading to the estimation of unreliable market factors. Finally, the choice for the comparison period method is justified by Brown and Warner (1980), who argue that the comparison period returns approach is at least as powerful as and often even more powerful as market adjusted approaches.

We estimate the mean return $\left(\mu_{n t}\right)$ of each security $i$ for a comparison period running from day -120 through day -20 prior to the day of the first public announcement $(t=0)$. The event period disturbance term can than be estimated by subtracting $\mu_{i f}$ from the realized return $R_{i f}$. We measure announcement-period returns from day -1 through day +1 , resulting in a cumulative abnormal return $C A R$ :

$$
C A R=\sum_{-1}^{+1} \bar{\varepsilon}_{t}
$$

where

$$
\begin{aligned}
& \bar{\varepsilon}_{t}=\left[(1 / N) \sum_{i=1}^{N} \varepsilon_{i t}\right] \\
& \varepsilon_{i t}=R_{i t}-\mu_{i t} \\
& \mu_{t}=\left[(1 / 100) \sum_{\cdot-120}^{-21} R_{i t}\right]
\end{aligned}
$$

We assume that the portfolio daily returns are normally distributed and stationary, which allows us to use a significance test for the null hypothesis of equality of event period and comparison period means based on the methodology of Mood, Graybill and Boes (1974).

\subsubsection{Results}

Table 2.6 shows the average abnormal returns for bidding and target firms, subject to the method of payment and the identity of the merger (REIT-REIT or non-REIT mergers). Panel A provides the two and three day CARs for 
Chapter 2. How Does the Market for Corporate Control Function for Property Companies?

acquisition targets, which are significantly positive $(8.66 \%)$ for the sample as a whole. The wealth effects we find are substantially higher than results reported by Campbell et al. (2001) and McIntosh et al. (1989), although these authors use a market model and do not distinguish between stock and cash payments. Compared to more general corporate finance studies, our results are lower than the $10 \%$ to $23 \%$ as found by for example Jensen and Ruback (1983) and Servaes (1991). The lower level of our results may well be caused by the homogeneity of assets of real estate companies, which decreases the potential for synergy profits emerging from merged operations.

Studying the abnormal returns to targets in more detail, we find that targets receiving a bid from a private firm receive higher abnormal returns in comparison to targets receiving a public bid. This might be due to the fact that the main part of private bids in our sample consists of MBOs: as the management of a company has superior knowledge of the firm, they will be best able to establish the exact value of the company and to create value following a takeover. Furthermore, we find that the scope of wealth effects for targets in REIT takeovers is different compared to wealth effects for targets in non-REIT takeovers. CARs in REIT takeovers financed with stock are quite similar to previous findings in the real estate literature, for example, Campbell et al. (2001) document a three day CAR of 3.2\%. However, we document CARs for cash bids that are substantially higher. This is in line with academic evidence that cash bids lead to higher CARs than stock bids, due to signalling effects (Myers and Majluf, 1984). However, this result has not been documented before, because previous comparable studies included stock-financed REIT takeovers only.

Finally, stock bids in non-REIT takeovers lead to insignificant wealth effects. On the one hand, the low number of stock bids in non-REIT mergers might be a driver of this result, but it might as well be an indicator for the aversion of shareholders against stock as a method of payment. This result is contrasting the significant wealth effects following stock-financed REIT takeovers. The latter might well be due to the fact that REITs are restricted in retaining cash, which leaves managers nothing but stock as a method of payment in takeovers.

Panel $B$ presents the shareholder wealth effects accruing to the bidders and shows that cash bidders earn an insignificant $0.33 \%$ abnormal return. Stock bidders earn a $0.48 \%$ return, but this result is insignificant as well. The performance of the bidders in our sample is lower than the 6.37\% CAR documented by Allen and Sirmans (1987), but is slightly better than results found by Campbell et al. (2001), who document a $-0.6 \%$ abnormal return. Again, these comparisons should be interpreted with care due to the difference in methodology. Our results confirm that takeovers in the listed real estate sector lead more favourable stock market reactions for bidders compared to findings in other sectors: Asquith et al. (1983), Travlos (1987). Hyun (1993) and Chang (1998) all find significantly negative bidder wealth effects for both stock and cash offers.

The findings of our event study show that takeovers in the real estate sector lead to significantly positive aggregate wealth effects, which confirms the inefficient management hypothesis. The results are generally in line with the real estate takeover literature, but we contribute to existing studies by including wealth effects following mergers of non-REITs. With respect to these mergers, we document larger CARs as compared to REIT mergers. Our findings differ from the finance literature, where larger gains to targets and larger losses to bidders have been documented. Our findings of small rather than large fluctuations in stock prices of targets and bidders seems to be justified by the homogeneity of operations in real estate mergers, which does not allow for large value-creating synergies. 
Table 2.6

Shareholder Wealth Effects for Targets and Bidders Following Takeovers

( $t$-statistics in parentheses)

\begin{tabular}{|c|c|c|c|}
\hline Panel A: Target Firms & $n$ & $\begin{array}{c}\text { CAR } \\
t[-1,0,1] \\
\end{array}$ & $\begin{array}{c}\text { CAR } \\
t[0,+1] \\
\end{array}$ \\
\hline All bids & 95 & $\begin{array}{c}8.66 \% \\
(3.23)^{* *}\end{array}$ & $\begin{array}{c}8.21 \% \\
(6.76)^{* *}\end{array}$ \\
\hline Cash Bids & 63 & $\begin{array}{l}10.86 \% \\
(3.27)^{* *}\end{array}$ & $\begin{array}{l}10.46 \% \\
(7.21)^{* *}\end{array}$ \\
\hline Stock/Mixed Bids & 32 & $\begin{array}{l}4.35 \% \\
(1.92)^{*}\end{array}$ & $\begin{array}{c}3.79 \% \\
(3.14)^{* *}\end{array}$ \\
\hline Public Bidder & 51 & $\begin{array}{c}6.95 \% \\
(3.00)^{* *}\end{array}$ & $\begin{array}{c}6.72 \% \\
(6.38)^{* *}\end{array}$ \\
\hline Private Bidder & 44 & $\begin{array}{l}10.10 \% \\
(3.04)^{* *}\end{array}$ & $\begin{array}{l}10.24 \% \\
(6.02)^{* *}\end{array}$ \\
\hline REIT Takeovers & 43 & $\begin{array}{c}6.69 \% \\
(3.25)^{* *}\end{array}$ & $\begin{array}{c}6.92 \% \\
(6.77)^{* *}\end{array}$ \\
\hline Cash & 15 & $\begin{array}{l}10.19 \% \\
(3.06)^{* *}\end{array}$ & $\begin{array}{l}10.39 \% \\
(7.67)^{* *}\end{array}$ \\
\hline Stock/Mixed & 28 & $\begin{array}{c}4.80 \% \\
(2.14)^{* * *}\end{array}$ & $\begin{array}{c}4.21 \% \\
(3.66)^{* * *}\end{array}$ \\
\hline Non-REIT Takeover & 37 & $\begin{array}{l}10.15 \% \\
(3.05)^{* *}\end{array}$ & $\begin{array}{l}10.27 \% \\
(6.02)^{* *}\end{array}$ \\
\hline Cash Bids & 33 & $\begin{array}{l}11.33 \% \\
(3.12)^{* *}\end{array}$ & $\begin{array}{c}10.27 \% \\
(6.27)^{* *}\end{array}$ \\
\hline Stock/Mixed Bids & 4 & $\begin{array}{l}0.06 \% \\
10.37\rangle\end{array}$ & $\begin{array}{l}-0.05 \% \\
(-0.01\}\end{array}$ \\
\hline Panel B: Bidding Firms & $n$ & $\begin{array}{c}\text { CAR } \\
t[-1,0,1]\end{array}$ & $\begin{array}{c}\text { CAR } \\
t[0,+1]\end{array}$ \\
\hline All Offers & 51 & $\begin{array}{l}0.37 \% \\
(0.39)\end{array}$ & $\begin{array}{l}0.48 \% \\
(0.86)\end{array}$ \\
\hline Cash Offers & 20 & $\begin{array}{l}0.33 \% \\
(0.28)\end{array}$ & $\begin{array}{c}0.34 \\
(0.42)\end{array}$ \\
\hline Stock Offers & 31 & $\begin{array}{l}0.48 \% \\
(0.22)\end{array}$ & $\begin{array}{l}0.80 \% \\
(0.58)\end{array}$ \\
\hline REIT Takeovers & 43 & $\begin{array}{l}0.27 \% \\
(0.23)\end{array}$ & $\begin{array}{l}0.77 \% \\
(0.50)\end{array}$ \\
\hline Cash & 14 & $\begin{array}{l}0.14 \% \\
(0.35)\end{array}$ & $\begin{array}{r}0.89 \% \\
(0.64)\end{array}$ \\
\hline Stock & 29 & $\begin{array}{l}0.23 \% \\
(0.19)\end{array}$ & $\begin{array}{l}0.31 \% \\
(0.44)\end{array}$ \\
\hline Non-REIT Takeovers & 8 & $\begin{array}{l}1.51 \% \\
(0.57)\end{array}$ & $\begin{array}{l}1.40 \% \\
(1.07)\end{array}$ \\
\hline
\end{tabular}

Notes: Table 2.6 presents the results of the event study on the wealth effects following takeovers in the real estate sector. Panel A reports the average three-day and two-day cumulative abnormal return to targets, thereby distinguishing cash bids and bids which are (at least partially) stock-financed. Moreover, we make a distinction between REIT-to-REIT takeovers and takeovers involving non-REITs. Panel B presents the event study results for bidders. $t$-statistics (in parentheses) are based on a conventional significance test for the null hypothesis of equality of event period and comparison period means, based on methodology of Mood et al. $(1974, p .435)$. Significance at the 0.10 and 0.05 levels is indicated by * and "* respectively. 


\subsection{Conclusions and Discussion}

The different aspects of the market for corporate control have been studied extensively in the corporate finance literature and to some extent in the real estate literature. This chapter adds to existing evidence by investigating the inefficient management hypothesis for the real estate sector during the most recent takeover wave, using an international sample. The real estate sector provides an interesting and increasingly important field of research, both because of the trend in institutionalization of the real estate sector and because of its distinct governance structure. Moreover, the documented lack of hostile takeovers for the real estate sector leads to the question whether the market for corporate control functions effectively for the property sector.

Our results indicate that, although the market for corporate control in the real estate sector does not discipline managers via hostile takeovers, poor firm performance is a predominant motive for takeovers. This confirms the inefficient management hypothesis and thereby adds new evidence to the existing real estate finance literature. However, the question why hostile takeovers do not take place in the real estate sector still remains unanswered. We suggest three explanations for this.

First, hostile takeovers do probably not create more value than friendly takeovers. The lack of hostile takeovers in the real estate sector does not allow for empirical testing of this hypothesis, but Schwert (2000) indeed finds that hostile bids have lower success rates and on average pay a higher premium to target shareholders.

Second, the most important characteristic of hostile takeovers is the information asymmetry that arises when a hostile bid is made. Despite this information asymmetry, managers are often willing to take the risk of overpaying because this premium will be offset by growth in future revenues. The information problem is relatively small in the real estate sector as the valuation of operations (i.e. a property portfolio) is rather straightforward. Therefore, we would expect a large number of hostile takeovers. However, in the real estate sector the growth of revenues is rather predictable and stable, so although the information asymmetry is less of a problem in hostile takeovers, it will take considerable time to regain possible overpayments in the real estate sector, making it an unattractive alternative to friendly takeovers.

Our third hypothesis is that the REIT structure increases transparency, which is so beneficial to corporate governance that it makes the market for corporate control less important as a governance mechanism. Or inversely, the REIT structure may decrease transparency due to dispersed stock ownership, thereby deterring hostile takeovers (Ghosh and Sirmans, 2003a). However, our sample shows that hostile takeovers do not take place in real estate markets without the REIT structure either, which suggests that the operations of real estate companies, whether they have a REIT-status or not, are relatively transparent. This reduces the need for an active market for corporate control by means of hostile takeovers.

The latter part of our study shows that the real estate takeover market does not only differ from other sectors with respect to hostile takeovers, but wealth effects surrounding takeovers are different as well. We document abnormal returns of a smaller scope as compared to wealth effects found in studies for other sectors, which is consistent with previous studies on takeovers in the real estate sector (Allen and Sirmans, 1987, Campbell, et al. 2001). The smaller scope of the wealth effects might be justified by the homogeneity in operations of real estate companies, which does not allow for large synergy benefits following mergers. 
Corporate Governance and Sustainability in Global Property Markets

Concluding, we can state that our findings indicate that the lack of hostile takeovers in the real estate sector does not by definition lead to a weak market for corporate control, as underperforming targets face an increased takeover likelihood. However, the exact reason for the lack of hostile takeovers is still hard to establish. The illiquidity of some of the smaller international real estate markets hinders a complete international study of the real estate takeover market and the use of a market model to establish shareholder wealth effects, thereby opening possibilities for future research. Furthermore, we investigate the takeover market as an important external governance mechanism, but apart from studying how governance structures differ between targets and bidders, we do not address interaction between external governance, internal governance and equity prices, which have recently been shown to be interrelated (Cremers and Nair, 2005). This might be an interesting venue for corporate governance research in real estate, because of the experimental laboratory offered by REITs and its distinct impact on corporate governance mechanisms. Finally, we study wealth effects following takeovers in the short run only. A long-run perspective could possible provide better insights in the wealth effect differences between takeovers in the real estate sector and results documented for takeovers in other sectors. 
Appendix 2.A

Description of Explanatory Variables

\begin{tabular}{|c|c|c|c|}
\hline Variable & Definition & Source & Based on Item \\
\hline \multicolumn{4}{|l|}{ Financial Characteristics } \\
\hline Stock Return & Monthly stock return & Datastream & $\mathrm{Rl}$ \\
\hline Return on Assets & Net income divided by total assets & Worldscope & WC08326 \\
\hline Return on Equity & Net income divided by total equity & Worldscope & WC08301 \\
\hline Growth in EPS & $\begin{array}{l}\text { Earnings per share growth during } \\
3 \text { financial years before } t\end{array}$ & Datastream & EPS \\
\hline $\begin{array}{l}\text { Funds from Operation } \\
\text { to Assets }\end{array}$ & $\begin{array}{l}\text { Sum of earnings, depreciation and amortization } \\
\text { divided by total assets }\end{array}$ & Worldscope & WC04201 \\
\hline Selling Expenditures & $\begin{array}{l}\text { Sum of selling, general and administrative } \\
\text { expenses divided by sales }\end{array}$ & Worldscope & WC01101 \\
\hline Beta & Variance in stock return & Worldscope & WC09802 \\
\hline Debt-to-Equity & Total debt divided by common equity & Worldscope & WC03255 \\
\hline Cash Holdings & $\begin{array}{l}\text { Cash and marketable securities divided by } \\
\text { total assets }\end{array}$ & Worldscope & WC02001 \\
\hline Dividend Yield & $\begin{array}{l}\text { Dividend per share as a percentage of } \\
\text { the share price }\end{array}$ & Datastream & DY \\
\hline Market Value & $\begin{array}{l}\text { Share price multiplied by the number of ordinary } \\
\text { shares outstanding }\end{array}$ & Datastream & MV \\
\hline Market-to-Book ratio & $\begin{array}{l}\text { Market value of common equity divided by } \\
\text { balance sheet value of common equity }\end{array}$ & Datastream & MTBV \\
\hline \multicolumn{4}{|l|}{ Governance Characteristics } \\
\hline \# of Non-Executives & $\%$ of non-executive directors on the board & Annual reports & \\
\hline Insider Holdings & $\%$ of shares held by directors of the company & Annual reports & \\
\hline Ownership Concentration & $\%$ of shares held by the 3 largest investors & Annual reports & \\
\hline External Management & Company managed by an external entity & Annual reports & \\
\hline Liquidity & \# of shares traded per day divided by market value & Worldscope & WC08011 \\
\hline \multicolumn{4}{|l|}{ Portfolio Characteristics } \\
\hline Property type & Sector of investment & Annual reports & \\
\hline International Investments & Cross-border investments (at least $25 \%$ ) & Annual reports & \\
\hline Diversification & Company invests in more than one asset & Annual reports & \\
\hline Development & $\begin{array}{l}\text { Company has development and/or construction } \\
\text { activities }\end{array}$ & Annual reports & \\
\hline
\end{tabular}

Notes: Appendix 2.A provides an overview of the explanatory variables exploited in the analysis of takeovers, including a short description. Source and item number are provided in columns three and four. All absolute values are expressed in nominal dollars. 


\section{Executive Compensation in U.K. Property Companies}

This chapter is based on Eichholtz, P.M.A.; Kok, N. and Otten, R. "Executive Compensation in Uk Property Companies." Journal of Real Estate Finance and Economics, 2008a, 36/4), pp. $405-26$. 


\section{Executive Compensation in U.K. Property Companies}

\subsection{Introduction}

Recently, the often very extensive executive compensation packages, which were originally designed to alleviate the agency problem between managers and shareholders, have attracted intense scrutiny by regulators, the general public, and academics. This scrutiny is fuelled by recent corporate scandals at companies such as Ahold and Enron, and by management pay hikes at times of worker lay-offs. Therefore, more emphasis has been put on the structure of executive compensation packages.

In this chapter, we present evidence on executive compensation practices in the real estate sector. However, unlike previous research on executive compensation in the real estate sector, which has been based on U.S. REITs, we focus on the U.K. property market. A REIT-like structure was only implemented in the U.K. in January 2007, and thus has not been available until very recently. The lack of a REIT structure implies that unlike their U.S. counterparts, U.K. property companies were not obliged to distribute at least $90 \%$ of income. Therefore, we expect agency problems to be more severe in the U.K. listed property market than in the U.S. REIT market.

We study a sample of 39 property companies listed in the United Kingdom between 1998 and 2003. We use three groups of variables to study the level of executive compensation. These are economic and accounting measures of performance, governance mechanisms, and asset-specific characteristics. We find that size is the most important determinant of executive compensation, and this relation is non-linear. Absolute and relative share performance significantly explains long-term compensation, management style has a distinct influence on the level of executive compensation, and using alternative monitoring mechanisms (institutional shareholders, debtholders, and outside directors) leads to higher levels of long-term incentives.

Next, we analyze changes in executive compensation, also referred to as pay-performance sensitivity or pay-performance elasticity. We document that the pay-performance sensitivity in U.K. property companies is weak. Executive shareholdings provide a much stronger link between pay and performance than does executive compensation.

To our knowledge, this is the first study to perform a detailed comparison between compensation practices in a non-U.S. property market and the evidence on executive compensation in the U.S. REIT sector. Furthermore, we elaborate on previous U.S.-based research by simultaneously studying the influence of three groups of variables on managerial compensation, using more detailed data for executive compensation and a broader spectrum of governance mechanisms than have been used in the past. 
The United Kingdom is by far the most transparent of all European listed property markets, with companies publishing an extensive remuneration report in their annual report. The remuneration reports have been published since disclosure rules in the United Kingdom were expanded, following the Greenbury report in 1995 and the Hampel report in 1998. They contain extensive information on the composition and magnitude of executive pay, including details on executive shareholdings and stock options. For this latter component of compensation, reporting requirements are even more stringent than are those for U.S. companies, which makes it possible for us to conduct a more in-depth study of the issue. Finally, the 1998-2003 sample period takes both the boom years of the late 1990s and the consequent downturn of the stock market into account.

This chapter proceeds as follows. Section 3.2 summarizes the empirical literature on the relation between executive compensation and company performance. Section 3.3 discusses our data. Section 3.4 presents our results for the drivers of executive compensation, while Section 3.5 provides evidence on the pay-performance sensitivity in U.K. property companies. Section 3.6 concludes.

\subsection{Literature Review}

\subsubsection{Corporate Finance}

Research on the issue of executive compensation is broad and elaborate. The most influential U.S.-based paper is that of Jensen and Murphy (1990) who study a sample of 1,049 companies for the period 1974-1986. They find that a $\$ 1,000$ increase in shareholder wealth leads to a $\$ 3.25$ increase in CEO wealth. Executive stock ownership accounts for most of this pay-performance sensitivity. In their study, the level of executive pay is mostly driven by company size. Size also influences the compensation-performance sensitivity, which is higher for small firms and lower for large firms.

Hall and Liebman (1998) use several different pay-performance measures. Using different methods might explain the difference in findings: when they divide the sample in percentiles according to performance, they find that compensation is positively and significantly related to performance. Moreover, levels of compensation as well as the pay-performance elasticity increase strongly over the sample period (1980-1994), which is almost totally due to the increased use of stocks and stock options in incentive schemes.

Main, Bruce, and Buck (1996) study executive compensation in the United Kingdom for the 1981 - 1989 period. They examine executive stock options and find that performance influences executive compensation, and that this influence is stronger and more significant than that found in prior research. They explain the increased sensitivity by the effectiveness of executive stock options. Their pay-size relation is consistent with findings in U.S.-based research. They find that sector performance is not significantly related to executive compensation.

Core, Holthausen, and Larcker (1999) study the effects of corporate governance mechanisms on the level of executive compensation and link compensation to stock performance. They find that weak inside governance, which they define by CEO duality and old, busy, dependent outside directors, leads to additional compensation for the CEO. For performance, Core et al. (1999) present evidence on a significantly negative relation between the predictable component of compensation, which follows from board and ownership structure variables, and stock 
market performance. This evidence suggests that board and ownership variables can be a proxy for managerial entrenchment, i.e., the absence of active monitoring by the board of directors.

Buck, Bruce, Main and Udueni (2003) are the first to study how the introduction of long-term incentive plans (LTIPS) in the United Kingdom changes the pay-performance sensitivity. They find that, while the LTIPs increase average total compensation, the presence of LTIPS actually leads to lower pay-performance sensitivity. This finding raises doubt on the effectiveness of LTIPS as a solution to the principal-agent problem.

Conyon, Core and Guay (2006) compare executive compensation practices in the United States and the United Kingdom and find that U.S. CEOs have higher pay and much higher incentives, but this difference narrows over time. Moreover, the authors attribute a portion of U.S. CEOs' relatively greater pay to the larger amount of risky incentives held.

\subsubsection{Real Estate Sector}

Research on executive compensation in the real estate sector is limited and focuses solely on the U.S. REIT market. In one of the first sector-specific studies, Chopin, Dickens, and Shelor (1995) hypothesize that revenues and unexpected profits positively influence executive compensation. They find that sales have a significantly positive impact on compensation, but that there is little effect of unexpected profits on executive pay.

Pennathur and Shelor (2002) study the determinants of executive compensation in the U.S. REIT industry by using a time frame of eight years (1992 - 1999). They examine pay changes rather than pure compensation levels, and find no significant relation between company performance and executive payments prior to 1997. But after 1997, the stock return shows a positive influence on executive remuneration. However, the measure of earnings-pershare is not related to raises in executive compensation. These authors introduce an industry-specific variable, and find that it is significantly and positively related to compensation.

Scott, Anderson, and Loviscek (2001) add sector-specific variables of property type to the model. They show that size is more important than performance in explaining total compensation, and moreover, that the type of property investment significantly influences total compensation of REIT executives. Industrial and healthcare REITs are associated with higher levels of executive compensation.

Because board structure and other governance mechanisms are supposed to restrict excessive executive compensation, Ghosh and Sirmans (2005) hypothesize that a well-structured governance system should lead to better monitoring and thus to a more efficient compensation structure. The governance variables they analyse include board size, the number of outside directors, CEO position in the board, and average executive age. Using the 1998-2000 period, they find that, contrary to other research, executive compensation is negatively related to stock performance. With respect to corporate governance, they find that board composition is an important determinant of executive compensation: a large board that includes old directors leads to higher levels of executive compensation, and that also holds for the presence of outside directors. Outside blockowners have a negative influence on executive compensation.

Pennathur, Gilley, and Shelor (2005) concentrate on option compensation packages rather than cash compensation. For their sample of U.S. REITs, they find that the level of option awards is positively related to 
Corporate Governance and Sustainability in Global Property Markets

accounting measures of performance, variability of returns, and growth opportunities, which is in line with evidence from the corporate finance literature.

\subsection{Data}

Here, we provide an overview of our sample, which we derive from the listed-property industry in the United Kingdom, and of executive compensation practices in that industry. For that purpose we use three separate sources of data. Our main source is company proxy statements, which provide a detailed executive remuneration report; information concerning director's stockholdings, governance mechanisms, and specifics about investment strategy; and the property portfolio. Our second source of data is the GPR Handbook of European listed property companies. The Handbook covers publicly listed property companies in 15 European countries. It also includes financial statistics, management information, and information concerning investment strategy and property acquisitions. Our third source of data is Datastream, which presents financial information.

We use the GPR universe of listed U.K. property companies. We select firms only if they are continuously listed for at least three years during the sample period, and if their annual reports are available for analysis. These criteria lead to a final sample of 39 companies over 1998-2003, and a total of 217 observations. Appendix 3.A lists the complete sample.

If we exclude companies that go bankrupt or are delisted during the sample period, doing so might lead to a survivorship bias. When we analyze the excluded companies, we see that approximately half were delisted due to mergers and acquisitions, and the remaining half were excluded due to nonavailability of information. No firms went bankrupt over the sample period. Therefore, we believe the impact of survivorship bias is limited.

The first statistics of our data set reveal several interesting observations. For investment focus, Table 3.1 indicates that the majority of the companies in the sample invest in property in the retail and office sector, and that $72 \%$ of the companies in the sample invest in more than one sector. Companies that invest in more than two different property sectors represent $26 \%$ of the sample. International diversification of U.K. property companies is rare: only $10 \%$ of the companies in the sample invest more than $25 \%$ of the portfolio in countries other than the United Kingdom. These findings are consistent with Boer, Brounen, and Op 't Veld (2005), who find that European real estate companies prefer investing locally to investing internationally, and prefer to diversify by sector. 
Table 3.1

Investment Focus within Sample

\begin{tabular}{lcc}
\hline Investment Focus & \# of firms & \% of sample \\
\hline Sectoral Diversification & 11 & \\
1 sector & 18 & 28.2 \\
2 sectors & 9 & 46.2 \\
3 sectors & 1 & 23.1 \\
4 sectors & & 2.6 \\
& & \\
Property Type & 32 & \\
Office & 24 & 82.1 \\
Retail & 12 & 61.5 \\
Industry & 5 & 30.8 \\
Residential & 5 & 12.8 \\
Other & & 12.8 \\
& & \\
International Diversification & 4 & 10.3 \\
International & 35 & 89.7 \\
National & & \\
\hline
\end{tabular}

Notes: Table 3.1 presents the investment focus for the sample of U.K. property companies for 1998 - 2003. Sectoral diversification shows the number of property types a company invests in, where we define property type as office, retail, industry, residential, hotel, healthcare, or other. We define a company as investing internationally if at least $25 \%$ of its portfolio is invested in a foreign market. Sources: Annual Reports, Global Property Research.

Table 3.2, Columns 1 through 3 show the percentages of firms that adopt different incentive plans over time. Initially, bonus plans are the most popular incentive payment, but executive stock options gain heavily in importance and by 2001, are used by most companies. Other long-term incentives, such as share appreciation rights (SARs) and restricted share plans, are not as commonly used as cash bonuses or stock options. Nevertheless, almost half of the companies in the sample use stock-based compensation as a managerial incentive. We note especially the decreased use of both bonus and option plans after 2001. This decrease could indicate that the downturn in the stock market triggered companies to reward executives in alternative ways.

In Table 3.2, Column 4 shows that the level of total compensation initially grows strongly during the sample period, which is mainly due to the influence of stock options. The lower average compensation level in 2002 reflects the downturn of the stock market, followed by a slight increase in 2003 when the stock market picks up again. 
Table 3.2

Incentive Plans Implemented

\begin{tabular}{ccccc}
\hline Year & $(1)$ & $(2)$ & $(3)$ & $(4)$ \\
& $\begin{array}{c}\text { Bonus } \\
\%\end{array}$ & $\begin{array}{c}\text { LTIP } \\
\%\end{array}$ & $\begin{array}{c}\text { Options } \\
\%\end{array}$ & $\begin{array}{c}\text { Compensation } \\
\text { in f1000 }\end{array}$ \\
\hline 1998 & 74.0 & 35.3 & 65.0 & 769.5 \\
1999 & 77.9 & 41.2 & 82.4 & 1013.7 \\
2000 & 80.3 & 44.1 & 89.0 & 1226.6 \\
2001 & 88.2 & 44.1 & 91.2 & 1511.1 \\
2002 & 74.4 & 47.1 & 79.5 & 1340.1 \\
2003 & 79.4 & 49.8 & 79.5 & 1418.9 \\
\hline
\end{tabular}

Notes: Columns 1 through 3 of Table 3.2 provide statistics on the percentage of companies that implement an incentive plan over time. Bonus represents the variable part of cash compensation, which is annually determined by the remuneration committee. LTIP is cash payments related to long-term stock plans, and options represent option plans implemented. Column 4 reflects the sample-average of total compensation per executive.

Figure 3.1 shows the development of the compensation structure over time. The relative importance of base cash compensation, including benefits and pension payments, first decreases and then slightly increases over time. The effects of the downturn in the stock markets become clear in year 2002, when the relative influence of executive stock options on total compensation decreases. The decrease in value of stock options is caused not only by depreciating stock prices, but also by the decreasing number of stock options issued. At the same time, the use of stocks as a compensation tool increases.

The diminishing popularity of stock options and the increasing importance of stock-based compensation in compensation schemes are contrasting developments in the United States, where stock options have gained in relative importance compared to compensation in shares (Conyon and Murphy, 2000). 
Figure 3.1

Structure of Executive Compensation over Sample Period

$(1998-2003)$

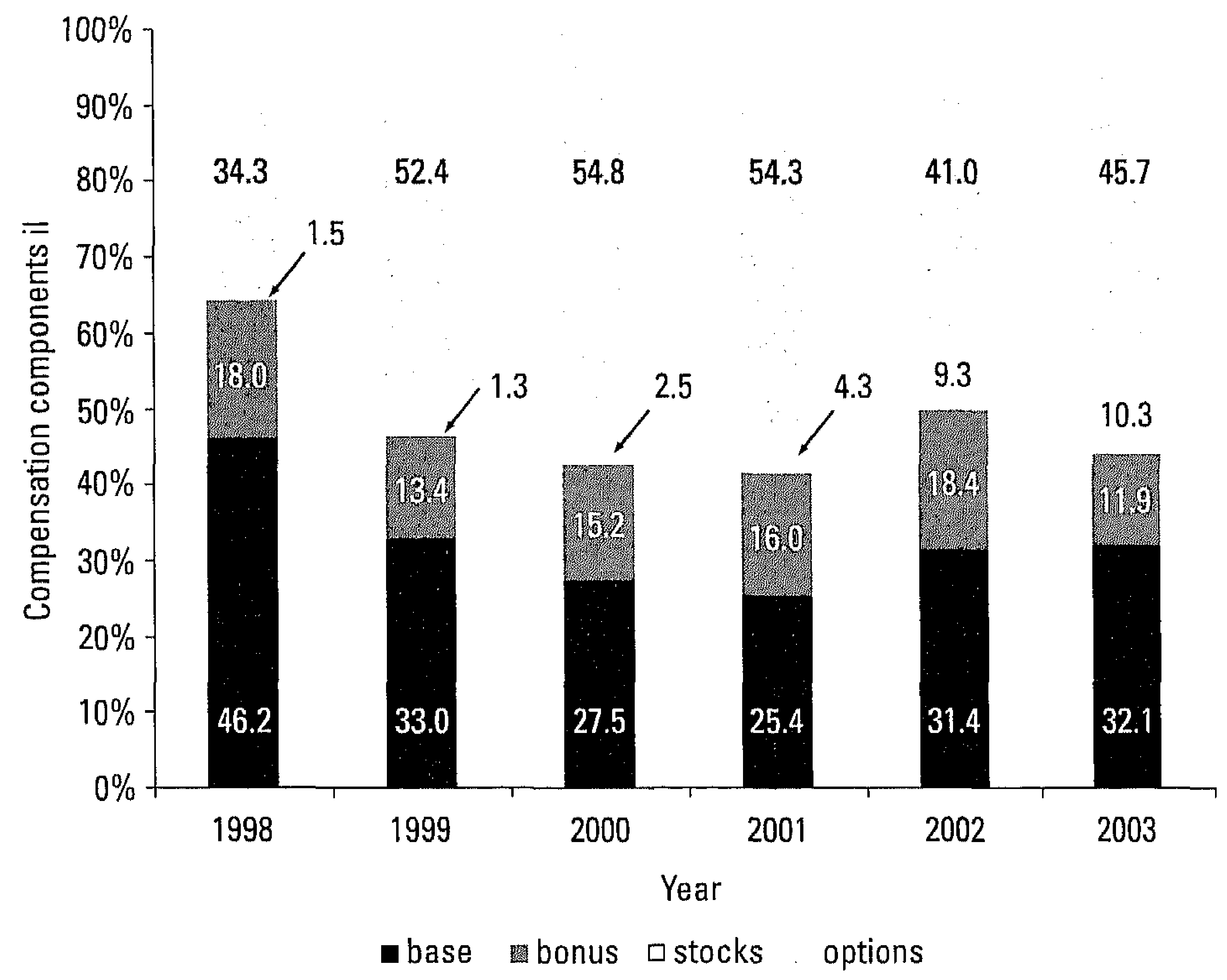

Notes: Figure 3.1 illustrates the structure of executive compensation plans and the relative importance of its elements to total compensation over time. Base compensation includes base salary, benefits and pension plans. Bonus is the amount of annually determined cash bonuses. Stocks reflect the sum of stock-based long-term compensation, including share appreciation rights (SARs). The variable Options includes previously granted stock options, currently granted options, and profits on exercise.

Table 3.3 presents the statistics for our main variables. The yearly average of executive base salary is $£ 203,460$ $(\$ 328,690) .^{12}$ This average is similar to the average level of base compensation found by Pennathur and Shelor (2002), who document a value of $\$ 332,482$ for the U.S. REIT sector in 1999. We find that the value of cash compensation, including bonus, is $£ 408,810(\$ 660,436)$, which is slightly lower than the $\$ 761,595$ found by Ghosh and Sirmans (2005) for the year 2000. However, the value of stock options is $£ 391,840$ ( $\$ 633,021$ ), which is almost equal to findings in U.S.-based research: Pennathur et al. (2005) find average option awards of $\$ 627,120$ for the 1997-2000 period. The similarity in levels of executive compensation between the U.S. REIT sector and the U.K. listed-property sector is in line with findings by Conyon et al. (2006) for the United States and the United Kingdom in general. Furthermore, the process of globalisation and the homogeneity of the listed property sector may explain our results.

12 We convert pound-denominated values to US\$ using the exchange rate at 01/01/2000, which was $0.619 \mathrm{f} / \$$. 
Corporate Governance and Sustainability in Global Property Markets

The level of average bonus payments does not exceed the average level of base salary, which is consistent with the best-practices recommendations in corporate governance that have been published by some governments in the past, and more recently by the EPRA (2004). On the other hand, the average value of stock options greatly exceeds the value of average base level compensation.

Table 3.3

Descriptive Statistics

Executive Compensation, Financial Characteristics and Governance Characteristics

\begin{tabular}{llrrrrr}
\hline & & Median & Mean & SD & Min & Max \\
\hline Executive Compensation & & & & & & \\
Salary & (f thousands) & 195.00 & 203.46 & 84.40 & 38.57 & 434.50 \\
Bonus & (f thousands) & 86.75 & 135.54 & 206.73 & 0.00 & 1600.00 \\
Benefits & (f thousands) & 15.33 & 17.84 & 17.92 & 0.00 & 160.33 \\
Pensions & (f thousands) & 23.50 & 51.97 & 86.12 & 0.00 & 389.00 \\
Stocks & (f thousands) & 0.00 & 29.03 & 77.41 & 0.00 & 493.66 \\
Options & (f thousands) & 145.33 & 391.84 & 1076.96 & 0.00 & 8791.84 \\
& & & & & & \\
Financial Characteristics & & & & & & \\
Market Value & (f millions) & 213.18 & 569.93 & 955.54 & 2.63 & 6163.05 \\
Shareholder Return & percent & 13.38 & 10.88 & 2.08 & -91.65 & 116.32 \\
Earnings-Per-Share & (f pence) & 11.64 & 23.05 & 38.96 & 0.00 & 345.01 \\
Market-to-Book Ratio & & 0.75 & 0.81 & 0.30 & 0.37 & 2.35 \\
Leverage Ratio & & 0.44 & 0.46 & 0.16 & 0.00 & 0.95 \\
& & & & & & \\
Governance Characteristics & & & & & & \\
CEO = Chair & & 0.00 & 0.15 & 0.36 & 0.00 & 1.00 \\
Shares Held by Executives & percent & 5.63 & 2.20 & 4.17 & 0.00 & 23.33 \\
Number of Outside directors & percent & 44.44 & 45.64 & 9.63 & 0.00 & 75.00 \\
Institutional Investors & (1=yes) & 0.00 & 0.36 & 0.48 & 0.00 & 1.00 \\
Ownership Concentration & percent & 37.25 & 37.11 & 15.77 & 6.26 & 87.21 \\
\hline & & & & & & \\
\hline
\end{tabular}

Notes: Table 3.3 provides a summary of statistics. Salany, bonus, benefits, and pensions are retrieved directly from the proxy statements. The value of stock-based compensation includes the value increase of restricted executive shares and share appreciation rights (SARs). Options are valued using the Black-Scholes (1973) option pricing formula plus gains made on exercise. We obtain financial characteristics from Datastream. Market capitalization is the number of shares outstanding times the stock price at year end. We measure company performance by continuous shareholder return, which we calculate by using the formula: $\left(n\left(p_{t}+d i v\right) / p_{t .1}\right)$ where $P$ and div are company share price and dividend, respectively. Earnings-per-share (EPS) are total earnings divided by the number of shares outstanding. We define the market-to-book ratio as the market value of the cormmon equity divided by the balance sheet value of the common equity in the company. We calculate the leverage ratio by dividing total debt by total equity. We collect data on governance characteristics from annual reports. $C E O=C h a i r$ is a dummy, set equal to one if the CEO is chairman of the board, and zero otherwise. Shares held by executives is the average number of shares per executive relative to the number of shares outstanding. Outside directors are non-executive board members, not necessarily independent. The institutional investor dummy is one if insurance companies or pension funds are major shareholders. Shares owned by five largest investors reflect total percentage of shares held by five major shareholders.

Sources: Annual Reports, Datastream, Global Property Research. 
The variables representing financial characteristics of the sample indicate that average stock return is relatively high $(10.88 \%)$ as compared to the FTSE100 index, which had an average annual return of $-2.5 \%$ over the 1998 2003 period. The overall outperformance of the listed-property sector in the U.K. is not reflected in the market-tobook ratio, which averages 0.81 . This discount contrasts with U.S. REITs, which on average trade at a premium during our sample period.

For corporate governance, Table 3.3 shows that in $20 \%$ of the property companies in our sample, the CEO is also chairman of the board. As it is generally perceived that the dual role of CEO and chairman may result in a conflict of interest, this number seems high. However, we note that among U.S. REITs, more than half of the companies still have a combined CEO-chairman in place in 2000 (Ghosh and Sirmans, 2005).

The average percentage of total shares held by executives is $2.2 \%$, which is lower than average CEO stockholdings in U.S. REITS. However, our study investigates the average for all executives rather than only the CEO. Institutional investors are, on average, present in less than half of the sampled firms. This finding is counterintuitive, as we would expect institutional investors to be well represented in listed property firms. However, traditionally, institutional investors in Europe prefer direct rather than indirect real estate investments, a trend that has started to change only recently.

\subsection{The Level of Executive Compensation}

To calculate executive compensation, we use the average instead of the total remuneration of the executive directors, including the CEO. The reason for using average executive compensation instead of only CEO compensation is that it is the board that collectively acts on behalf of the shareholders. The detailed data for our sample provides insight into the compensation of all executives individually. However, because we focus on the average executive compensation of all executives rather than on just the CEO's compensation, comparing our results with those in other studies should be done with caution.

We measure the average level of executive compensation by using two variables. REMCASH is the sum of base salary, bonus, benefits, and pension payments. REMLT is the sum of grants of executive share options, compensation in shares and long-term cash incentives. In REMLT we value grants of options using the Black and Scholes (1973) option-pricing formula. We value and revalue all options granted at the end of each fiscal year, and if options are exercised during the year, we add up the profits on exercise.

We value stock-based compensation by calculating the yearly increase in the value of incentive-based executive shares. During the past few years, the practice of granting options and shares with additional performance requirements has developed. Since options and share-plans vest in the unforeseeable future, we follow Core et al. (1999) and assume that firms set performance targets equal to expected performance. Therefore, we include the full expected value of options and shares. 


\subsubsection{Economic - and Accounting Measures of Performance}

To measure performance, we introduce five variables. We use all variables in a current and a lagged term to account for the influence of past performance on current compensation. First, we calculate the total stock performance (PERF). Second, we repeat the analysis with the Jensen $\alpha$, which we calculate against both the FTSE Small Cap Index and the FTSE Real Estate Index. Earnings per share (EPS) is our third performance measure. An accounting measure of performance might be able to explain executive compensation better than could an economic measure of performance, as it is less affected by exogenous factors (Pennathur and Shelor, 2002). Fourth, we include dividend yield (DIV), and finally, we include the discount/premium at which a company trades (1-MTB). Ling and Ryngaert (1997) show that REIT stock prices can differ substantially from their underlying real estate prices (Net Asset Value, NAV). Closed-end fund studies often interpret this premium/discount as a sign of management quality (Dimson and Minio-Kozerski, 1999). Therefore, we test for the impact of the discount on managerial compensation. Appendix 3.B presents the correlation matrix for the independent variables and the dependent variables of executive compensation.

Table 3.4 presents the results of the full multivariate regression of the elements of executive compensation on company characteristics. The results are robust for time and size. Panel A shows that absolute stock performance is negatively but insignificantly related to the level of cash compensation. We repeat the analysis using the Jensen $\alpha$ and obtain similar results. ${ }^{13}$ The relation between stock performance and the level of long-term compensation is significantly positive, which is due to the strong sensitivity of the elements of long-term compensation to market movements. Lagged share performance also shows a significantly positive relation with the level of long-term compensation. This delayed effect might be due to executives being eager to exercise their stock options immediately after a successful previous year.

Our findings partially contrast with studies on U.S. REITs: the link between pay and performance seems to be weaker for REITs as compared to non-REITs. However, it should be noted that we study more recent time frame than most REIT compensation studies.

EPS is not significantly related to either cash or long-term compensation. This is consistent with Pennathur and Shelor (2002), but contrasting expectations that bonuses are based on accounting measures of performance.

We find that dividend yield is significantly and negatively related to cash compensation. This finding might indicate that high dividend payouts reduce the free cash flow problem, which otherwise could lead to exaggerated compensation of executives. Moreover, companies with high dividend payouts might lack the opportunity of positive NPV investments, which signals possible lower future profits to investors and leads to lower current compensation.

Our results show a negative relation between the discount at which property companies trade and the level of long-term compensation. This suggests that managers of badly performing companies receive lower compensation, which confirms the view in closed-end fund studies that the discount is a measure of managerial quality. $^{14}$

13 Results for regressions with Jensen $\alpha$ instead of absolute performance are not reported, but are available from the authors on request.

14 See for instance Berk and Stanton (2007). 


\subsubsection{Governance Mechanisms}

Our second set of explanatory variables contains governance and board structure variables. First, we include a variable representing the percentage of shares owned by executives (SHRDIR). We measure SHRDIR by the average percentage of shares owned by the executives. The second variable is the relative proportion of outside directors on the board (OUTS). We define directors as outsiders if they are non-executives, thereby including board members who are appointed by the current CEO. Thus, outside directors are not by definition independent. We measure ownership concentration among shareholders (BLOCK) by calculating the percentage of shares owned by the top five shareholders. If the CEO of a company is also the chairman of the board, we introduce a binary dummy (CEOOWN) in the model. We add a dummy for the presence of institutional investors among shareholders (INSTI). This variable is set equal to one if institutional investors are present among shareholders. Our last governance mechanism is debtholders, for which we use the debt-to-equity ratio (DEBT) as our proxy. We measure this ratio by dividing the book value of total debt by common equity.

Panel B of Table 3.4 presents the empirical results for the effects of governance mechanisms on executive compensation. Large stockholders do not seem to be efficient in governing executives. This result is contrasting REIT studies, which document a negative relation between the presence of block holders and the level of CEO compensation (Ghosh and Sirmans, 2005). Because block ownership formation in REITs is restricted by the 5-50 rule, large shareholders might be encouraged to intensify monitoring.

The presence of institutional investors is positively related to long-term executive compensation. This finding could be because institutional investors prefer incentive-based compensation, which witnessed a huge increase in value during the end of the 1990s. However, Webb, Beck, and McKinnon (2003) argue that institutional investors are less efficient in monitoring than is widely assumed.

As do compensation studies on REITs (Ghosh and Sirmans, 2005) and non-real estate firms (Core, et al. 1999), we question the functionality of outside directors as a monitoring mechanism. We do so because we find that the number of outside directors is significantly and positively related to both short- and long-term executive compensation. Furthermore, we find that in a situation in which the CEO is also chairman of the board, long-term executive compensation is lower than it is when the tasks of CEO and chairman are separated. This finding is counterintuitive, as the dual role of the CEO creates the opportunity for abuse of power, which could lead to higher compensation levels. This relation might indicate that stakeholder monitoring becomes more intense when the CEO has a dual role, leading to lower compensation levels.

Executive stock ownership is positively related to both cash and long-term compensation. The positive relation might indicate that executives with large shareholdings have a strong incentive to boost stock performance, which would not only lead to higher values of their stockholdings, but simultaneously increase the value of longterm compensation packages.

We find a significant positive relation between the debt-to-equity ratio and the level of cash executive compensation. Ghosh and Sirmans (2005) suggest that debtholders act as a monitoring device, such that managers are paid more in current compensation and less in long-term benefits. However, our results show a positive influence of the debt-equity ratio on long-term compensation as well. This finding leads to the question of whether debtholders are in fact an effective substitute monitoring mechanism. 


\subsubsection{Asset Characteristics}

Many studies document a relation between managerial style and the level of executive compensation (Bertrand and Schoar, 2003). Although we have no data on manager-specific characteristics, our data set contains detailed information on the asset base of the property companies in our sample. We use the data on asset characteristics as a proxy for managerial style, because the right property and investment strategy can lead to superior performance (Myer and Webb, 2000). Also, the riskiness of the investment style can have a direct impact on the pay-performance relation (Aggarwal and Samwick, 1999). We relate the investment style of a property company to the level of cash and long-term compensation, assuming that managers are financially rewarded for strategies that lead to higher risk-adjusted returns.

We include several variables to account for the investment style of a property company. First, we introduce an international investment dummy (INT), which we set equal to one if a company invests internationally, and zero otherwise. To qualify as international, a company must have invested at least $25 \%$ of its portfolio in one or more foreign countries. Second, we distinguish between different property types, categorized as office (OFFICE), retail (RETAIL), residential (RES), industrial (INDUS), and other investments (OTHER). Third, we define an investment focus on high- or low-quality property by the variable QUALITY. We can assess whether a company invests in high-or low-quality property by analysing the proxy statements of that company, and by the company's explicit managerial statements corporate focus on quality. Finally, we control for size and time by introducing market capitalization (CAP), its interaction term (CAP)', and year dummies.

Panel $\mathrm{C}$ of Table 3.4 provides the results for the multivariate regression of the asset-specific variables on the two measures of executive compensation. A management style that opts for international diversification of investments results in both lower cash and long-term compensation levels. This finding is consistent with Eichholtz, Koedijk, and Schweitzer (2001), who show that property companies with an international investment style underperform property companies that focus on a single market.

The sector dummies, which are relative to the retail sector, show that investing in residential and industrial property leads to lower compensation levels, but an investment style that focuses on office property does not lead to significantly different compensation levels. Our findings support other evidence that residential and industrial real estate underperform the office and retail sector on a risk-adjusted basis (Lee, 2001, Myer and Webb, 2000), which leads to lower compensation levels. Moreover, we hypothesize that residential and industrial property investments can be regarded as 'non-glamourous.' The retail and office sector are generally more 'glamourous' investments, with key projects that garner a lot of media attention, which leads to more exposure for the management and the need for high-profile executives.

Finally, property companies with a focus on quality property have higher managerial rewards. This finding confirms our expectations, because high-quality real estate is generally regarded as low risk, but well performing (Baum, 1994).

On size, the consensus in the corporate finance and real estate studies predicts a positive influence of company size on executive compensation. The relation between size (CAP) and compensation is also strongly positive in the U.K. listed-property sector. We are interested to note that this relation is not monotonically positive. When we insert an interaction term, (CAP)? we see a significantly negative coefficient for this variable. This non-monotonic 
Chapter 3. Executive Compensation in U.K. Property Companies

relation indicates that executive compensation quickly increases in small companies, but for executives in large companies, the increase is much weaker and even becomes negative if a company gets too large. A calculation shows us that, ceteris paribus, REMCASH maximizes at a market capitalization of $€ 1.2 \mathrm{bln}$. (\$1.9bln.).

The control dummy for time clearly reflects the upward trend in executive compensation, as the coefficients for YEAR all show significantly positive signs. We note that we assume that our regression coefficients are stable over time. Although we control for time-period differences by including time dummies, we also check that our results are robust over time. We do so by performing regressions for all years separately. The coefficients prove to be consistent over the years, indicating that they are time-robust. Overall, the explanatory power of our models is high, with adjusted R-squares varying from 0.59 to 0.64 for REMCASH and REMLT, respectively. 
Table 3.4

Regression Results

dependent variable: logarithm of cash compensation(1) or long-term compensation (2)

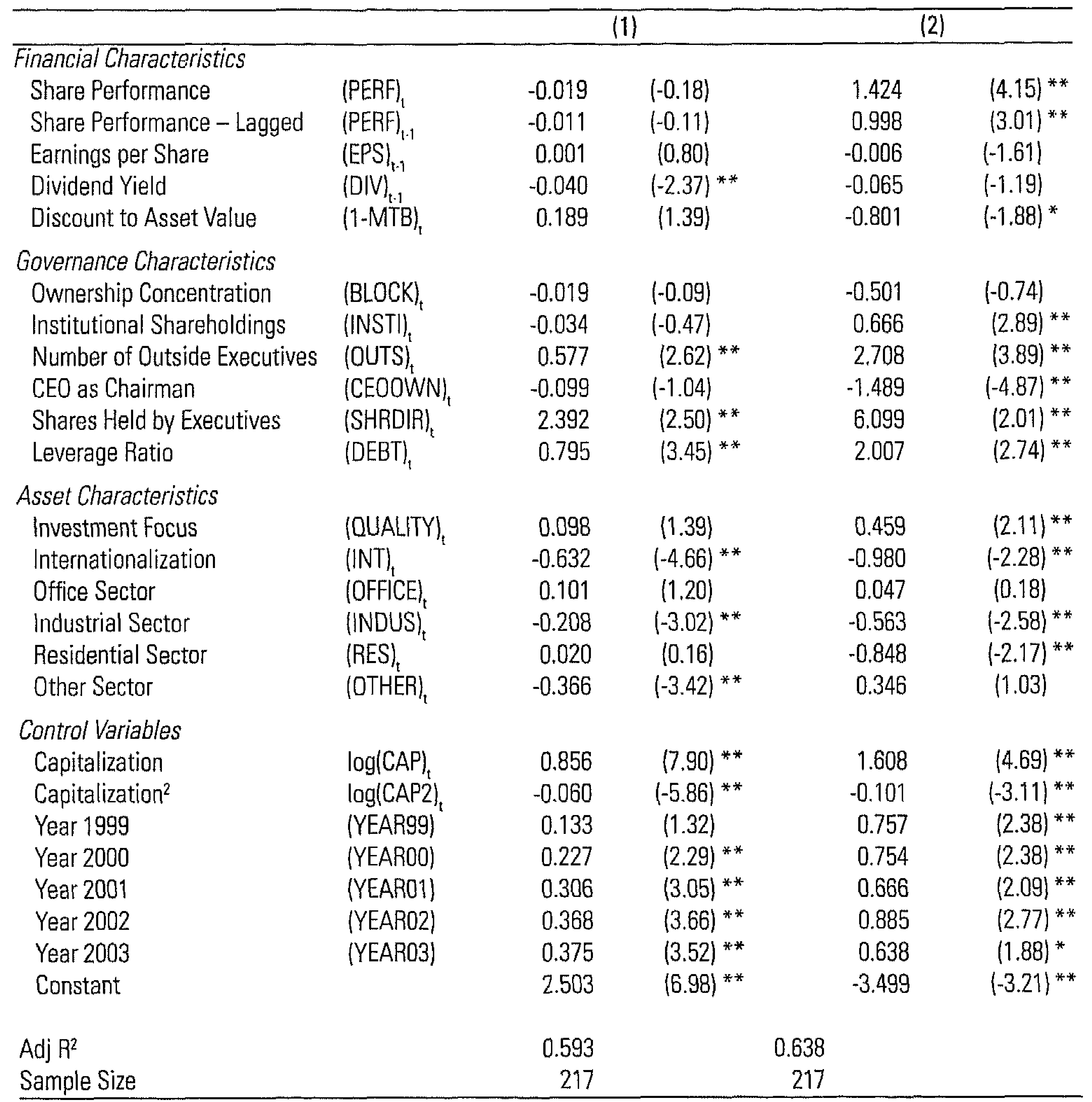

Notes: Table 3.4 presents the results of the multivariate OLS test that explains the level of executive compensation. In column (1), the natural logarithm of REMCASH if the dependent variable, including base compensation, benefits, pension plans, and cash bonuses. In column (2), the natural logarithm of REMLT includes long-term incentives stocks and options. PERF is the continuous shareholder return. EPS are earnings divided by the number of shares outstanding. DN is the dividend per share divided by the share price. (1-MTB) represents the discount/premium calculated by one minus market value over book value of assets. BLOCK reflects the total percentage of shares held by the five largest shareholders. INSTI is an institutional investor dummy, set to one if institutional investors are among the major shareholders, and zero otherwise. OUTS is the percentage of non-executives, not necessarily independent, directors on the board. CEOOWN is a dummy set equal to one if the CEO is also the chairman of the board, and zero otherwise, SHRDIR are shares held by executives and is calculated by the average number of shares per executive relative to the number of shares outstanding. We calculate LEVERAGE by dividing total debt by total equity. The OUALITY dummy is one if a company invests in high quality property, which can be assessed through analysis of the proxy statements of a company, and by explicit managerial statements with respect to corporate focus on quality. INT defines the company as investing internationally if at least $25 \%$ of its portfolio is invested in a foreign market. The SECTOR dummies represent the sector in which a company invests, with RETAIL as the base dummy. CAP is a company's market capitalization. CAP' is an interaction term capturing the nonlinear relation between company size and compensation. YEAR is a control dummy that captures the time effect. White's (1980) heteroskedasticity robust t-statistics are in parentheses. Significance at the 0.10 and 0.05 levels is indicated by * and ** respectively. 
In previous research on executive compensation, several authors raise the issue of endogeneity. Among others, Agrawal and Knoeber (1996), Ghosh and Sirmans (2005), and Mishra and Nielsen (2000) show that compensation, performance, and corporate governance are interrelated, which might lead to biased OLS results. Like Mishra and Nielsen (2000), we use a 2SLS approach within a simultaneous system of equations, where stock performance, executive stockholdings and compensation are the endogenous variables. The total system includes three equations and 17 exogenous variables.

Our performance equation includes CEO duality, insider holdings, board independence, ownership concentration, presence of institutional investors, pay-related incentives, and control variables. We follow the agency theory, expecting that a well-structured board, high insider ownership, and the presence of alternative governance mechanisms enhance performance. On the other hand, CEO duality leads to entrenchment, which is detrimental to performance.

Incentives through executive compensation might have a positive effect on performance. Thus, the insiderholding equation includes performance, pay-related incentives, the governance variables, and control variables. Executives of well-performing firms are more willing to hold shares of their company. We expect that the use of long-term compensation packages, especially stock awards, leads to higher insider holdings. Moreover, an independent board and the presence of alternative governance mechanisms might lead to stronger alignment of interest through more insider holdings. Finally, the compensation equation includes performance, insider holdings, the discount to asset value, variables on the style of the property company, a selection of governance mechanisms, year dummies, and control variables. We also use cash compensation and long-term compensation as dependent variables in the compensation equation. All three equations include firm size and the debt-equity ratio. We drop at least two exogenous variables from each equation and structure each equation such that we can exploit the 2SLS method to estimate the system.

We do not report the results of our robustness check here, since we find that our results on the drivers of cash and long-term compensation are consistent with those reported above. Governance and asset characteristics are the main explanatory variables of executive compensation, but performance only explains long-term compensation levels. ${ }^{15}$

For the drivers of performance, we show that all the corporate governance variables except CEOOWN have a nonsignificant influence on the performance of property companies in our sample. For insider holdings, we find that the presence of large stockholders and a high leverage ratio have a positive impact on the size of insider holdings. This finding indicates that alternative governance mechanisms increase the alignment of interest between managers and shareholders.

15 Extensive discussion of all results falls outside of the scope of this paper. However, the results are available from the authors on request. 


\subsection{Changes in Executive Compensation; The Pay-Performance Sensitivity (PPS)}

Most of the studies on executive compensation focus on the relation between executive pay and company performance. To gain a deeper insight into the pay-performance relation, we examine the influence of performance on changes in executive payment. This method follows Jensen and Murphy (1990), Pennathur and Shelor (2002), and Zhou (2000), who find that a model that measures changes has advantages in capturing factors that influence the pay-performance relationship over time.

Unfortunately, there is no consensus among studies on the appropriate model specification. Coughlan and Schmidt (1985) and Gibbons and Murphy (1992) prefer the elasticity specification, but Jensen and Murphy (1990) use the arithmetic sensitivity approach. Zhou (2000) includes both model specifications in his study, and Rosen (1992) documents the differences between all models.

The different model specifications do not yield similar results, but neither the sensitivity nor the elasticity approach strictly dominates the other. One advantage of the sensitivity approach is its clear economic interpretation; further, this method enables us compare the PPS results to executive shareholdings. Because executive shareholdings are directly related to shareholder wealth and represent the most powerful link between corporate performance and executive wealth, we use the PPS approach and exploit the elasticity approach as a robustness check. The model specification for the PPS is

$\Delta(\text { Compensation })_{11}=a+\beta * \Delta\left(\right.$ Shareholder $\cdot$ Wealth $_{\mathrm{it}}+\varepsilon_{\mathrm{it}}$

where $\Delta$ (Compensation $)_{\text {it }}$ is the annual change in cash or long-term compensation, $\Delta(\text { Shareholder } \cdot \text { Wealth })_{i t}$ is the rate of return realized by shareholder multiplied by the company market value at $t-1$, and $\varepsilon_{\text {it }}$ represents the error term.

For the pay-performance elasticity (PPE) the model specification is

$\Delta \ln (\text { Compensation })_{1 t}=\alpha+\beta * \Delta \ln \left(\right.$ Shareholder $\cdot$ Wealth $_{i t}+\varepsilon_{i t}$

where $\Delta \ln$ (Compensation) is the annual change in the natural logarithm of cash or long-term compensation, $\Delta \mathrm{ln}$ (Shareholder. Wealth) is the natural logarithm continuous return including dividends, and $\varepsilon_{\text {it }}$ represents the error term.

Table 3.5 summarizes the results for model 1. Panel A provides the estimated PPS for the entire sample. In Panel $B$, we control for size by including a dummy variable for large firms. In Panels $C$ through $F$, we examine the influence of different governance mechanisms on the PPS. We note that although the R-squares seem to be low, they are comparable to findings in similar studies.

Panel A of Table 3.5 shows that for the sensitivity of cash compensation to shareholder wealth, $B$ equals 0.00004 ; for every $£ 1,000$ increase in shareholder wealth, the cash compensation paid to the executives increases by $£ 0.04$. 
This value is comparable to findings by Murphy (1999), who documents cash PPS-figures ranging from 0.008 for the industry sector to 0.073 for the utility sector during 1990-1996. Zhou (2000) also includes the lagged increase in shareholder wealth in the model and finds a cash PPS of 0.08 for the Canadian market during 1994-1996, slightly higher than we find in our sample. The sensitivity between long-term compensation and shareholder wealth is $\mathrm{f} 0.20$ per 11,000 , which is higher than the sensitivity of cash compensation to performance, a finding that is consistent with the consensus in other studies on PPS. Long-term compensation yields a higher PPS than cash compensation, because long-term compensation is in the form of options and stocks, which are more closely linked to stock performance. The total PPS of executives in the U.K. property sector is the sum of cash compensation PPS and longterm compensation PPS: for every $£ 1,000$ increase in shareholder wealth, executive wealth increases $£ 0.24$.

We also perform three robustness checks. First, we investigate the PPS over time and find that the PPS trends upwards over the sample period, indicating that executives are increasingly paid on the basis of performance. The PPS of cash compensation is consistently lower than the sensitivity of long-term compensation to performance, and has negative coefficients during the downturn of the stock market in 2001 and 2002. These negative coefficients show that the basic salary of executives is robust to the volatility of the stock performance.

Second, we use the elasticity approach described in model 2. Although the $t$-statistics improve slightly - most notably, we document a significant cash compensation-performance elasticity - the sign of all results is similar to the PPS analysis and the explanatory power of the models is approximately the same. However, the elasticity approach does not have a straightforward interpretation in terms of 'absolute' incentives, so we do not report further on these results. Here, we discuss only the results of the pay-performance elasticity analysis.

Third, the comparison between small and large firms in Panel B indicates that the PPS is lower in larger firms, although the interaction coefficients lack statistical significance. Therefore, we split the sample into small and large firms and repeat the PPS analysis. The (unreported) results confirm that the PPS is stronger in small firms. Our finding is consistent with Jensen and Murphy (1990) and Zhou (2000), both of which studies find that small, rather than large, companies drive the PPS in the sample. The inverse relation between size and the PPS may indicate that large firms encounter problems in bridging the agency gap between managers and owners. On the other hand, the absolute values of changes in market capitalization of large companies are usually so large that they ensure significant changes in executive wealth.

Panels $C$ through $F$ present the results on the influence of different governance mechanisms on the PPS. In Section 3.4.2, we found no evidence that the presence of large blockholders was related to the level of executive compensation. However, the PPS results show that the presence of blockholders increases the long-term PPS and thus aligns interests of owners and managers of a company. This relation indicates that blockholders act as an effective monitoring mechanism.

Based on evidence presented in Section 3.4.2, we questioned the effectiveness of outside directors on the board, because the level of executive compensation increases with the number of outside directors. However, when we look at the changes in executive compensation, we find evidence of an increasing PPS when the number of outside directors on the board increases. An explanation for this result might be the preference of outside directors for long-term incentives, which turns out to be an efficient link between pay and performance. 
Corporate Governance and Sustainability in Global Property Markets

The presence of debtholders does not significantly influence the PPS. As a robustness check, we split the sample into high-and low- leverage firms and find that the cash PPS is significant for the subsample of highly levered companies, but it is not significant for the subsample of low-levered companies. This finding is intuitive: debtholders have an incentive to reduce cash compensation, because it might affect the ability of a company to service debt. This incentive increases the necessity for debtholders to take over the monitoring task traditionally performed by shareholders. 
Table 3.5

Regression Results Pay-Performance Sensitivity

dependent variable: $\Delta$ cash compensation (1) or $\Delta$ long-term compensation (2)

\begin{tabular}{|c|c|c|c|c|}
\hline \multirow{2}{*}{ A. All Firms } & \multicolumn{2}{|c|}{ (1) } & \multicolumn{2}{|c|}{ (2) } \\
\hline & & & & \\
\hline$\Delta$ (Shareholder Wealth) & 3.59E-05 & $(0.96)$ & 2.00E-04 & $(2,02)^{* *}$ \\
\hline Constant & 33.34 & $(2.87)^{* *}$ & 38.95 & (1.27) \\
\hline Adj $R^{2}$ & 0.005 & & 0.023 & \\
\hline \multicolumn{5}{|l|}{ B. Company Size } \\
\hline Size Dummy & 22,24 & $(0.96)$ & -9.79 & $(-0.16)$ \\
\hline$\Delta($ Shareholder Wealth) & $2.39 \mathrm{E}-04$ & (1.33) & $6.82 \mathrm{E}-04$ & $(1.44)$ \\
\hline Dummy* $\Delta($ Shareholder Wealth $)$ & $-2.12 \mathrm{E}-04$ & $(-1.16)$ & $-5.04 E-04$ & $(-1.04)$ \\
\hline Constant & 22.48 & $(1.33)$ & 45.83 & $(1.02)$ \\
\hline Adj $R^{2}$ & 0.019 & & 0.029 & \\
\hline \multicolumn{5}{|l|}{ C. Blockholders } \\
\hline Ownership Concentration Dummy & -5.96 & $(-0.25)$ & -12.03 & $(-0.20)$ \\
\hline$\Delta($ Shareholder Wealth) & $3.79 \mathrm{E}-05$ & $(0.92)$ & $2.57 E-05$ & $(0.25)$ \\
\hline Dummy* $\Delta($ Shareholder Wealth) & $-9.65 E-06$ & $(-0.09)$ & $1.12 \mathrm{E}-03$ & $(4.28)^{* *}$ \\
\hline Constant & 36.16 & $(2.26)^{* *}$ & 40.61 & $(1.01)$ \\
\hline Adj $R^{2}$ & 0.006 & & 0.116 & \\
\hline \multicolumn{5}{|l|}{ D. Outsiders } \\
\hline Outsider Dummy & 20.17 & $(0.86)$ & 39.88 & $(0.65)$ \\
\hline$\Delta$ (Shareholder Wealth) & $-1.26 E-05$ & $(-0.18)$ & $5.90 \mathrm{E}-04$ & $(3.21)^{* *}$ \\
\hline Dummy $\Delta($ Shareholder Wealth $)$ & $6.91 \mathrm{E}-05$ & $(0.83)$ & $5.42 \mathrm{E}-04$ & $(2.49)^{* *}$ \\
\hline Constant & 22.40 & (1.29) & 15.82 & $(0.35)$ \\
\hline Adj $R^{2}$ & 0.013 & & 0.059 & \\
\hline \multicolumn{5}{|l|}{ E. Debtholders } \\
\hline Debt Dummy & -11.65 & $(-0,50)$ & 21.96 & (0.35) \\
\hline$\Delta($ Shareholder Wealth) & $-2.03 E-05$ & $(-0.39)$ & $1.99 \mathrm{E}-04$ & (1.43) \\
\hline Dummy ${ }^{*} \Delta($ Shareholder Wealth) & 1.18E-04 & $(1.57)$ & $-1.44 \mathrm{E}-06$ & $(-0.01)$ \\
\hline Constant & 37.97 & $(2.34)^{* *}$ & 28.39 & $(0.66)$ \\
\hline $\operatorname{Adj} R^{2}$ & 0.021 & & 0.023 & \\
\hline \multicolumn{5}{|l|}{ F. Institutional Investors } \\
\hline Institutional Investor Dummy & 6.17 & $(0.09)$ & 7.91 & $(0.12)$ \\
\hline$\Delta($ Shareholder Wealth $)$ & 1.89E-04 & (1.39) & $1.70 \mathrm{E}-04$ & $(1.29)$ \\
\hline Dummy* $\Delta$ (Shareholder Wealth) & $1.13 \mathrm{E}-04$ & $(0.54)$ & 7.12E-05 & $(0,35)$ \\
\hline Constant & 68.78 & $(1.70)^{*}$ & 35.21 & $(0.90)$ \\
\hline Adj $R^{2}$ & 0.007 & & 0.007 & \\
\hline
\end{tabular}

Notes: Column (1) of Panel A of Table 3.5 presents the pay-performance sensitivity (PPS) of the sample. The first part of the PPS is the result of regressions between the increase in shareholder wealth, $\triangle$ (Shareholder wealth), and the increase in cash compensation, $\triangle(R E M C A S H)$. We calculate the increase in shareholder wealth by multiplying the return to shareholders at time tby the market value at time $t-1$. The increase in cash compensation equals the sum of increases in base salary, benefits, pension plans, and bonuses, respectively. The second part of the PPS (Column 2) equals the sensitivity between the increase in long-term compensation $\triangle(R E M L T$ ) and the increase in shareholder wealth, where $\triangle(R E M L T)$ is the sum of annual increase in the value of stock and option plans. In Panel B we introduce a dummy, LARGE, and an interaction term, $\angle A R G E^{*} \triangle$ (Shareholder wealth), to capture the effect of size on the PPS. The dummy is set to one for companies with a market capitalization above the median. Pane/s C, D, E, and F present evidence on the effect or block ownership, outside directors on the board, debtholders, and institutional stockholders, on the PPS, respectively. We capture the effects of the governance mechanisms on PPS by intraducing dummies in the model. White's (1980) heteroskedasticity robust $t$-statistics are in parentheses. Significance at the 0.10 and 0.05 levels is indicated by * and ** respectively. 
Although executive compensation provides a direct way to link executive wealth to shareholder wealth, our results show that this link is weak at best. On the other hand, the value of executive stock ownership is perfectly correlated with changes in shareholder wealth and is therefore often referred to as the most powerful incentive to align the interest of executives and shareholders (Jensen and Murphy, 1990). The percentage of a firm's total shares outstanding owned by executives is a direct estimate of the executives' sensitivity to performance. In Table 3.6, we summarize executive stockholdings and how these holdings vary under the influence of various governance mechanisms.

Table 3.6 shows that the average executive stockholding in our sample is $2.26 \%$, which implies that if the executive holds an average percentage of the firm's stock, then for every $£ 1000$ increase in stock value, his wealth from stock ownership increases by $\mathrm{f22.60}$. Compared to the total PPS from executive compensation that we documented earlier - that a $f 1,000$ increase in shareholder wealth leads to a $f 0.24$ increase in executive wealth - this result clearly illustrates the extremely powerful incentive of executive stockholdings.

Furthermore, Table 3.6 shows that executive stockholdings are negatively related to firm size and, with the exception of outside directors, - executive stockholdings are higher in firms with alternative governance mechanisms in place. This latter finding indicates that alternative monitoring mechanisms increase the alignment of interest between managers and stakeholders.

Table 3.6

Executive Stockholdings

\begin{tabular}{lcc}
\hline & Mean & Median \\
\hline Full Sample & $2.26 \%$ & $0.58 \%$ \\
Company Size & & \\
$\quad$ Small & & \\
$\quad$ Large & $2.46 \%$ & $1.09 \%$ \\
Ownership Concentration & $2.05 \%$ & $0.38 \%$ \\
$\quad$ High & $2.75 \%$ & $1.29 \%$ \\
Low & $1.77 \%$ & $0.44 \%$ \\
Number of Outside Directors & & \\
High & $2.01 \%$ & $0.43 \%$ \\
Low & $2.51 \%$ & $1.23 \%$ \\
Leverage Ratio & & \\
High & $3.42 \%$ & $1.07 \%$ \\
Low & $1.09 \%$ & $0.46 \%$ \\
Institutional Investors & & \\
$\quad$ Yes & $2.41 \%$ & $0.87 \%$ \\
No & $2.03 \%$ & $0.43 \%$ \\
\hline
\end{tabular}

Notes: Table 3.6 shows the mean and median executive stockholdings in our sample. First, we calculate these values for the full sample. Second, we distinguish between executive shareholdings in small and large companies by creating two subsamples, companies under and above the median market capitalization. We apply the same procedure using ownership concentration, the number of outside directors, leverage ratio, and institutional investors as the sorting variables. 


\subsection{Summary and Conclusions}

In this chapter we study the drivers of executive compensation in the U.K. listed-property sector. The U.K. market is especially important to study, as the tax-efficient REIT structure was not available in the United Kingdom during our sample period. The lack of the REIT structure implies that the usual restriction of $90 \%$ income distribution does not hold, which in turn might increase agency conflicts.

The United Kingdom is also ideally suited to executive compensation research, since the publication of remuneration reports in the proxy statements, which contain detailed information on previously granted options, makes it possible for us to create a clear and full insight into compensation practices. Using three sets of variables (economic and accounting performance, governance mechanisms, and asset characteristics) we study both the level and changes in executive compensation.

Our main conclusions are fivefold. First, consistent with previous research on U.S. REITs (Ghosh and Sirmans, 2005), we find that company size is the most important variable in explaining the level of executive compensation. However, we find that the relation between company size and compensation is nonlinear. This observation indicates that executive compensation quickly increases in small companies, but for executives in large companies, the increase is much weaker and may even turn negative.

Second, both absolute and relative measures of performance can explain the level of long-term executive compensation, but these measures are not related to cash compensation. These findings contrast U.S. REIT research, which shows mixed results for the relation between compensation and performance.

Third, we document results for the influence of governance mechanisms on executive compensation. We find evidence that institutional investors, debtholders, and outside directors prefer long-term incentives, such as stock option grants and stock grants. This preference leads to higher long-term compensation levels when there is a bull market, but also to a stronger link between pay and performance. CEO duality does not lead to increased entrenchment, which contrasts with findings for U.S. REITs. This difference might be explained by the unrestricted legal environment in which U.K. property companies operate, as opposed to the U.S. REITs. The stringent rules that apply to REITs have resulted in highly complex organizational structures, which might in turn lead to the entrenchment of senior management (Ghosh and Sirmans, 2005). On the other hand, the restrictions on block ownership that apply to REITs seem to lead to increased investor scrutiny, as block ownership negatively influences compensation levels in REITs (Ghosh and Sirmans, 2005). This finding contrasts with the nonsignificant relationship between block ownership and compensation levels that we document for U.K. property companies.

Fourth, we introduce asset-specific variables into our model as our proxy for managerial style. We find that geographical diversification leads to lower levels of executive payment, but investing in high-quality property is positively related to compensation. Executives of companies investing in the 'glamorous' retail and office property earn more than do their colleagues investing in 'non-glamour' industrial and residential property. This finding can be partly explained by the risk-adjusted performance of the respective sectors. 
Fifth, we present evidence on the changes in executive compensation by adopting the pay-performance sensitivity (PPS) approach. To our knowledge, this approach has not been used before in real estate studies on executive compensation. We show that a $£ 1,000$ increase in shareholder wealth leads to an average $f 0.24$ increase in executive wealth for our sample of companies. The pay-performance sensitivity is stronger and more significant for smaller firms, a finding that is consistent with Jensen and Murphy (1990) and Zhou (2000). Although executive compensation provides a direct link between shareholder wealth and executive wealth, we find that executive shareholdings provide a much more powerful incentive for executives to create shareholder wealth. 
Appendix 3.A

Sample Overview

\begin{tabular}{llll}
\hline Company Name & \multicolumn{3}{c}{ Years in Sample } \\
\hline A\&J Mucklow Group & 1998 & - & 2003 \\
Benchmark Group Group & 1998 & - & 2003 \\
British Land Company & 1998 & - & 2003 \\
Brixton Plc & 1998 & - & 2003 \\
Canary Wharf Group & 1999 & - & 2003 \\
Capital \& Regional & 1998 & - & 2003 \\
Chelsfield & 1998 & - & 2003 \\
CLS Holdings & 1998 & - & 2003 \\
Countryside Properties & 1998 & - & 2003 \\
Daejan & 1998 & - & 2003 \\
Derwent Valley Holdings & 1998 & - & 2003 \\
Development Securities & 1998 & - & 2003 \\
Freeport & 1998 & - & 2003 \\
Grainger Trust & 1998 & - & 2003 \\
Great Portland Estates & 1998 & - & 2003 \\
Grosvenor Land Holdings & 2000 & - & 2002 \\
Hammerson & 1998 & - & 2003 \\
Hampton Trust & 1998 & - & 2003 \\
Helical Bar & 1998 & - & 2003 \\
International Real Estate & 1998 & - & 2002 \\
Land Securities & 1998 & - & 2003 \\
Liberty International & 1998 & - & 2003 \\
London \& Associated Properties & 1998 & - & 2003 \\
London Merchant Securities & 1998 & - & 2003 \\
Marylebone Warwick Balfour Group & 1999 & - & 2003 \\
McKay Securities & 1998 & - & 2003 \\
Merivale Moore & 1998 & - & 2002 \\
Minerva & 1998 & - & 2003 \\
NHP & 2000 & - & 2003 \\
Pillar Property & 1998 & - & 2003 \\
Quintain Estates and Development & 1998 & - & 2003 \\
Regus & 2000 & - & 2003 \\
Rugby Estates & 1999 & - & 2002 \\
Shaftesbury & 1998 & - & 2003 \\
Slough Estates & 1998 & - & 2002 \\
St. Modwen Properties & 1998 & - & 2003 \\
Town Centre Securities & 2000 & - & 2003 \\
Warner Estate & 1999 & - & 2003 \\
Workspace Group & & & 2003 \\
\hline & 1998 & - & \\
& & &
\end{tabular}

Notes: Appendix 3.A presents our sample of 39 U.K. property companies, created from the U.K. universe and provided by Global Property Research for the 1998-2003 period. We include companies in the final sample if (a) they were listed on a continuous basis for at least three years during the sample period, and (b) if necessary data was available. The excluded companies are: Ashtenne Holdings, Bourne End Properties, Bradford Properties Trust, Burford Holdings, Capital Shopping Centre, Chorion, Delancey, Estates \& General, Frogmore, Moorfield Group, Mountview Estates, Peel Holdings, Smith Estates, Stockbourne. The Unite Group. Tops Estates, Warnford Investments, and Wates City of London. 
Appendix 3.B

Correlation Matrix

\begin{tabular}{|c|c|c|c|c|c|c|c|c|c|c|}
\hline \multicolumn{2}{|c|}{ REMCASH } & REMLT & PERF & PERFt-1 & EPS & \multicolumn{2}{|c|}{ DIV DISCOUNT } & \multirow[t]{2}{*}{ BLOCK } & \multirow[t]{2}{*}{ INSTI } & \multirow[t]{2}{*}{ DUTS } \\
\hline $\ln (\mathrm{REMLT})$ & 0.53 & & & & & & & & & \\
\hline PERF & -0.06 & 0.22 & & & & & & & & \\
\hline PERFt-1 & 0.02 & 0.18 & -0.06 & & & & & & & \\
\hline EPS & 0.19 & -0.04 & 0.10 & 0.08 & & & & & & \\
\hline DIV & -0.25 & -0.23 & 0.21 & -0.10 & 0.00 & & & & & \\
\hline DISCOUNT & -0.20 & -0.37 & -0.29 & -0.17 & -0.36 & 0.29 & & & & \\
\hline BLOCK & -0.26 & -0.23 & -0.12 & -0.11 & -0.16 & -0.04 & 0.11 & & & \\
\hline [NST| & 0.11 & 0.37 & 0.06 & 0.05 & 0.09 & -0.21 & -0.11 & -0.19 & & \\
\hline OUTS & 0.15 & 0.17 & 0.00 & -0.02 & 0.10 & 0.17 & -0.12 & 0.01 & -0.02 & \\
\hline CEOOWN & -0.16 & -0.50 & -0.13 & -0.13 & 0.10 & 0.13 & 0.23 & 0.09 & -0.32 & 0.08 \\
\hline SHRDIR & 0.10 & 0.12 & -0.10 & -0.13 & -0.10 & -0.26 & -0.03 & 0.16 & -0.04 & -0.07 \\
\hline DEBT & -0.10 & -0.14 & -0.16 & -0.17 & 0.01 & -0.12 & -0.12 & 0.31 & -0.08 & 0.02 \\
\hline QUALITY & 0.03 & 0.31 & 0.03 & 0.04 & -0.14 & -0.12 & 0.02 & 0.02 & 0.35 & 0.00 \\
\hline INT & -0.24 & 0.01 & 0.00 & -0.05 & -0.08 & 0.05 & 0.07 & 0.14 & 0.14 & 0.17 \\
\hline OFFICE & -0.03 & -0.04 & -0.08 & -0.03 & 0.14 & -0.16 & -0.10 & 0.06 & -0.09 & -0.02 \\
\hline INDUS & -0.12 & -0.22 & -0.01 & -0.05 & -0.03 & 0.15 & 0.07 & 0.00 & -0.10 & 0.05 \\
\hline RES & 0.09 & -0.14 & 0.08 & 0.05 & 0.54 & 0.06 & -0.24 & -0.02 & -0.14 & -0.01 \\
\hline OTHER & -0.07 & 0.06 & -0.08 & -0.03 & -0.15 & 0.03 & 0.07 & 0.21 & -0.22 & -0.11 \\
\hline CAP & 0.55 & 0.52 & 0.01 & 0.05 & 0.10 & -0.08 & -0.25 & -0.44 & 0.19 & 0.14 \\
\hline \multirow[t]{2}{*}{ CAP2 } & 0.46 & 0.46 & 0.00 & 0.03 & 0.07 & -0.07 & -0.24 & -0.42 & 0.19 & 0.13 \\
\hline & JOWN & SHRDIR & DEBT & OUALITY & INT & OFFICE & INDUS & RES & OTHER & CAP \\
\hline \multicolumn{11}{|c|}{$\ln (\mathrm{REMLT})$} \\
\hline \multicolumn{11}{|l|}{ PERF } \\
\hline \multicolumn{11}{|l|}{ PERFt-1 } \\
\hline \multicolumn{11}{|l|}{ EPS } \\
\hline \multicolumn{11}{|l|}{ DIV } \\
\hline \multicolumn{11}{|l|}{ DISCOUNT } \\
\hline \multicolumn{11}{|l|}{ BLOCK } \\
\hline \multicolumn{11}{|l|}{ INSTI } \\
\hline \multicolumn{11}{|l|}{ OUTS } \\
\hline \multicolumn{11}{|l|}{ CEOOWN } \\
\hline SHRDIR & -0.10 & & & & & & & & & \\
\hline DEBT & 0.16 & 0.25 & & & & & & & & \\
\hline QUALITY & -0.15 & -0.04 & -0.13 & & & & & & & \\
\hline INT & -0.01 & 0.51 & 0.22 & 0.13 & & & & & & \\
\hline OFFICE & -0.01 & 0.17 & 0.12 & -0.33 & 0.17 & & & & & \\
\hline INDUS & 0.08 & -0.05 & 0.12 & -0.23 & -0.22 & 0.07 & & & & \\
\hline RES & 0.10 & -0.03 & 0.11 & -0.09 & -0.11 & -0.19 & -0.06 & & & \\
\hline OTHER & -0.14 & 0.21 & 0.15 & -0.05 & 0.10 & -0.05 & -0.19 & 0.08 & & \\
\hline CAP & -0.10 & -0.03 & -0.37 & 0.24 & -0.05 & 0.04 & -0.18 & -0.08 & -0.07 & \\
\hline CAP2 & -0.04 & -0.08 & -0.32 & 0.26 & -0.03 & 0.06 & -0.20 & -0.12 & -0.10 & 0.98 \\
\hline
\end{tabular}

Notes: Appendix 3.B provides the total correlation matrix for all variables. Figures in bold are significant at the $5 \%$ level. 


\section{Corporate Governance and Performance: The REIT Effect}

This chapter is based on Bauer, R.; Eichholtz, P.M.A. and Kok, N. "Corporate Governance and Performance: The Reit Effect." forthcoming Real Estate Economics, 2008. 


\section{Corporate Governance and Performance: The REIT Effect}

\subsection{Introduction}

The legal setting and organizational structure under which U.S. Real Estate Investment Trusts (REITs) operate, changes the traditional principal-agent setting. Dividend payout maximization - in effect the reduction of the free cash flow problem as described by Jensen (1986) - is less of a concern for REITs, as US law requires a 90\% mandatory payout of net earnings. This legal obligation limits the opportunities for managerial expropriation and is often introduced in countries with a weak legal system, for example Brazil, Chile and Ecuador, as a legal substitute for the weakness of other mechanisms that protect shareholders (La Porta, Lopez-De-Silanes, Shleifer and Vishny, 1998). In the case of U.S. REITs, which are embedded in one of the world's strongest legal environments, the mandatory payout of net earnings was never implemented for reasons of shareholder protection. Therefore, the reduction of the agency problem is merely a favorable side-effect. Under the substitution hypothesis (La Porta, et al. 2000), the legal restrictions regarding REITs might mitigate the need for strong internal corporate governance mechanisms, i.e. corporate governance is less likely to be important for REITs than for regular corporations (Hartzell, et al. 2004).

On the other hand, it has been argued that the legal restrictions on REITs do not solve the agency problem. REIT managers face an obligatory $90 \%$ payout distribution over net earnings, which is after a substantial depreciation expense. The difference between net earnings and free cash flow creates discretionary cash, and REIT managers can freely decide on the actual payout ratio of this free cash flow. ${ }^{16}$ Moreover, legal restrictions regarding ownership structure, the so-called 5-50 rule, deters the formation of large block holders, and might protect REIT managers from the scrutiny of the market for corporate control (Eichholtz and Kok, 2008). Therefore, a competing hypothesis states that the legal setting in which REITs operate should be complemented by internal corporate governance mechanisms - as in regular corporations - to prevent managerial entrenchment and to reduce agency problems to a minimum.

Under this 'complement' hypothesis, we would expect that the relation between firm-level corporate governance and firm performance, which has been consistently documented in the literature, holds for U.S. REITs as well. However, Klapper and Love (2004) and Durnev and Kim (2005) find that a strong institutional setting weakens the well-documented link between corporate governance and performance. Under the substitution hypothesis, the strong legal setting in which companies operate mitigates the need for firm-level corporate governance

16 Several papers have shown that the actual payout ratio of RElTs is often more than $90 \%$ of net earnings. See for example Wang, Erickson and Gau (1993), Downs, Guener and Patterson (2000) and Gosh and Sirmans (2006). 
mechanisms, and deviating from the optimal corporate governance structure is therefore less costly. Hence, one could expect the relation between corporate governance structure and REIT performance to be relatively weak.

Studying the structure and effectiveness of corporate governance in REITs is relevant, as the growing international property investment flows are increasingly allocated through indirect property vehicles such as Real Estate Investment Trusts (REITS) and unlisted property funds rather than directly owned property investments. Meanwhile, an increasing number of countries introduce or have recently introduced a REIT-like structure to facilitate capital inflows in the real estate sector. ${ }^{17}$ The combination of both trends yields the need for in-depth research on the structure and effectiveness of corporate governance mechanisms in REITs.

This chapter contributes to the existing real estate corporate governance literature in three ways. First, instead of relying on self-constructed governance measures, we use the Corporate Governance Quotient index (CGO), a database that is produced by one of the leading governance data providers, Institutional Shareholder Services (ISS). ${ }^{18}$ This index is widely used in practice and includes most of the governance mechanisms that are relevant for investors. Recent examples of investor recognition of ISS in the real estate sector are for example NAREIT reports using ISS data and the advisory role of ISS in the merger between SL Green Realty and Reckson Associates Realty. ${ }^{19}$ Our index includes governance measures on eight different categories and thus represents a much more complete proxy of corporate governance than for example the often-used G-Index, which is constructed by Gompers, Ishii and Metrick (2003). The G-Index is based on the Investor Responsibility Research Center (IRRC) surveys and covers only two categories of corporate governance: investor rights and takeover protection. The use of a governance index has the advantage of capturing the effects of all individual governance mechanisms in one single number (Black, Jang and Kim, 2006, Boehren and Odegaard, 2003). To our knowledge, this is the first real estate study that exploits a comprehensive corporate governance index.

Second, we not only investigate the governance-performance relation for the real estate sector, but we also provide results for the complete $\mathrm{CGO}$ dataset, and we perform three robustness checks. We use the complete CGO dataset, which includes more than 5,000 U.S. companies to test whether our specific governance index yields results similar to the existing literature. As a first robustness check we test whether our results are REIT-specific, as it has been documented that firms with a relatively high share of fixed assets ('hard capital') generally have fewer possibilities to engage in value-destructing behavior (Gertler and Hubbard, 1988). To this end, we match the REIT sample with a control sample of firms that have a high corporate real estate ratio. The second control sample is constructed by selecting all REITs in the G-Index dataset, to test whether our findings are database-specific. The last robustness check distinguishes REITs with high dividend payout ratios from those with low payout ratios.

The third contribution of the chapter is that we use a broad set of performance measures and methodologies to estimate the impact of corporate governance on firm performance. First, we measure the effect of corporate governance on firm value using an OLS regression approach with Tobin's $Q$ as the dependent variable. Second, we estimate the effect of corporate governance on operating efficiency, where return on assets (ROA), return on equity (ROE), the net profit margin (NPM), sales growth (SALES) and funds from operations growth (FFO) are the proxies.

17 See Eichholtz and Kok (2007) for a detailed overview of recent international trends in global listed property markets.

18 Institutional Shareholder Services has been acquired by the Risk Metrics Group in January 2007.

19 NAREIT Portfolio Magazine. July/August 2005. 
In line with the substitution hypothesis, we find that corporate governance does not matter for firm value and operating performance in a sample of U.S. REITs. The control sample of REITs selected from the G-Index sample does not show a relation between corporate governance and firm value and operating performance either. Results for the sample of regular corporations and for the control sample of companies with high real estate ownership, consistently show a significantly positive relation between corporate governance, operating performance and firm value. When we split the REIT sample based on the dividend payout ratio, it appears that governance is important for the subsample that includes REITs with relatively low payout ratios - and therefore large discretionary cash flows. However, only internal corporate governance mechanism seems to be valueenhancing, whereas other governance mechanisms are less important than for regular corporations. We explain the distinct findings for REITs by the mandatory payout rule and operational restrictions that apply to REITs, which make deviation from the optimal governance structure less costly, and could therefore weaken the relation between governance and performance.

The rest of chapter 4 is structured as follows. In the next section we will shortly review the literature on the relation between firm-level corporate governance and performance. In Section 4.3, we describe our dataset, which comprises the ISS Corporate Governance Quotient index and financial information. In Section 4.4, we will address the impact of governance on firm value and operating performance, using Tobin's $Q$ and four measures of operating performance. We study the complete database, followed by the analysis of the REIT-sample and the control samples. Finally, Section 4.5 provides discussion and conclusions to this chapter.

\subsection{Literature Review: Corporate Governance and Performance}

A large body of literature, in real estate as well as in corporate finance, investigates the relation between corporate governance and performance. Most studies thereby focus on one specific aspect of governance, such as ownership structure, board composition, or executive compensation, and relate this to performance. In their widely-cited paper, Gompers, Ishii and Metrick (2003, GIM) construct a so-called 'G-Index', in which takeover provisions are used as a proxy for the level of shareholder rights. The creation of an index allows for alternative methodologies, but it should be noted that the GIM index is based on one aspect of corporate governance only. Creating 'democracy' and 'dictatorship' portfolios, the authors find evidence that a trading strategy buying firms with the highest shareholder rights and selling companies with the lowest shareholder rights, earns average annualized abnormal returns of $8.5 \%$ from 1990 to 1999 . Moreover, firm value (Tobin's 0) is inversely related to the number of takeover provisions. Following their paper, a new stream of literature has emerged, using different samples and methodologies, all exploiting governance indices rather than individual governance measures.

First, several studies focus on a specific country. Drobetz, Schillhofer and Zimmermann (2004) investigate the impact of governance on firm performance using a self-constructed corporate governance rating for the German market. Their results are in line with GIM, as governance ratings are positively related to firm valuation and a zero-cost trading strategy that shorts firms with low ratings and buys firms with high ratings leads to an annualized abnormal return of $12 \%$ over the sample period. Black, Jang and Kim (2006) are the first to test for endogeneity issues in the relation between an overall governance index and firm value, for a sample of Korean firms. The results indicate that the relation between their corporate governance index and firm value is causal, 
thereby eliminating some of the often-voiced concerns on the endogeneity of the relation between governance indices and firm performance.

Second, several studies strongly criticize GIM, based on further empirical tests that use the G-Index. Cremers and Nair (2005) investigate the impact of a corporate governance index on performance, but also include two measures of internal governance. They find that firms with a low number of takeover provisions outperform firms with a high number of takeover provisions, but this effect is conditional on stock ownership by pension funds, which indicates the importance of the interaction between the internal and external mechanisms of control. Contrary to GIM, Core, Guay and Rusticus (2006) find that the difference between stock returns of good and bad governance portfolios reverses after 1999, although their findings strengthen the relation between the G-Index and operating performance.

Third, the effect of regulatory environments on the relation between corporate governance and firm valuation - as discussed by La Porta, Lopez-De-Silanes, Shleifer and Vishny (2002) - has been studied using aggregate corporate governance measures. Klapper and Love (2004) find that firm-level corporate governance is most important in countries with poor investor protection, using a sample of 500 firms across 25 emerging countries. They note that a strong institutional setting might act as a substitute for firm-level corporate governance. Similarly, Durnev and Kim (2005) investigate the effect of legal environments on corporate governance practices in a multi-country setting. Using the CLSA database, they find for a sample of 859 firms in 27 countries that investment opportunities, the need for external financing, and ownership structure all affect the quality of corporate governance. Furthermore, firms with better governance enjoy a higher valuation, measured by Tobin's Q. Most importantly, all these relations are stronger in less investor-friendly countries.

Real estate research on the relation between corporate governance and performance mainly focuses on the functioning of individual monitoring mechanisms. The results of these analyses can subsequently be compared to general corporate governance research, to judge whether the distinct legal setting of REITs indeed affects transparency. Monitoring mechanisms that have been the subject of performance-related real estate research include board structure and/or ownership structure (Friday and Sirmans, 1998, Friday, et al. 1999, Ghosh and Sirmans, 2003b), management structure (Ambrose and Linneman, 2001, Cannon and Vogt, 1995, Howe and Shilling, 1990. Hsieh and Sirmans, 1991, Wei, Hsieh and Sirmans, 1995), inside ownership (Capozza and Seguin, 2003. Han, 2006), involvement of institutional investors (Chan, Leung and Wang, 1998, Ling and Ryngaert, 1997), and a combination of different governance mechanisms (Hartzell, et al. 2004, Hartzell, Sun and Titman, 2006). ${ }^{20}$

More recently, Bianco, Ghosh and Sirmans (2007) examine the relationship between the G-Index and performance of REITs. They find a relation between the takeover index and performance in 2004 , but this result disappears in 2006. The authors argue that the irrelevance of the G-Index in more recent times suggests that external governance is ineffective for REITs, and therefore, REIT corporate governance studies should pay more attention to the efficiency of internal governance mechanisms.

20 This short list of real estate studies on the relation between corporate governance and performance is by no means meant to be complete, but merely provides an overview of the monitoring mechanisms that have been studied in relation to performance in the real estate sector hitherto. 


\subsection{Data}

To study the aggregate impact of corporate governance on REIT performance, we exploit the Corporate Governance Quotient (CGQ) index, provided by Institutional Shareholder Services. The CGQ index is based on public disclosure documents, which are used to gather data on 61 different issues in the following eight categories: 1) board of directors, 2) audit, 3) charter and bylaw provisions, 4) anti-takeover provisions, 5) executive and director compensation, 6) progressive practices, 7) ownership, and 8) director education (see Appendix 4.A for a detailed overview of all rating criteria). Based on this information and an internal scoring system, ratings are calculated for each company. ${ }^{21}$

Two ratings are assigned to each company: one score relative to peers that are included in the stock index to which the company belongs, and one score relative to peers in the industry group. Furthermore, four different sub scores are calculated to provide a measure of a company's governance in a particular governance area. These four governance areas include: board of directors, takeover defences, executive and director compensation and ownership, and audit review. Higher values of these index numbers imply better alignment of shareholder and manager interests, more shareholder power, and more transparency. Besides the objectivity of the ratings and the broad range of governance variables included, the distinguishing feature of the CGQ index lies in its relative character, which ensures cross-sectional variability in corporate governance scores. The relative ranking opposes the absolute ratings that are used in for example the G-Index.

The CGQ database starts in 2002, but we restrict our analysis to the $2003-2005$ ratings, as data on sub indices are not or only partially reported before 2003. The initial number of companies in our sample is 4,950 in 2003 and increases to 5,260 in 2005 . For our analysis, we match the corporate governance scores at the beginning of each year with financial data at the end of the respective year, where the latter is obtained from Compustat. We require that the firms in the sample have financial data available, which reduces our dataset to 11,572 observations (firm-years). After our initial analysis on the complete dataset, we select all equity and mortgage REITs, leading to an initial REIT sample size of 216 property companies in 2003, increasing to 228 property companies in 2005. The information criterion leads to a final REIT dataset of 509 observations (firm-years).

To get a first insight in the CGO index, Panel A of Table 4.1 provides the average corporate governance scores of industries ranking in the top- 5 and bottom- 5 in 2005 . For purpose of comparison, we use the company scores relative to the index to which the company belongs. The real estate sector scores remarkably well, together with the capital-intensive industry 'utilities'. Among the low-ranked industries, we find 'telecommunication services', 'media', and 'personal products'. According to Brounen and Eichholtz (2005) these three industries are characterized by relatively low corporate real estate ratios. The descriptives are surprising, given the empirical evidence that firms with a concentration of 'hard' capital already have fewer possibilities to engage in valuedestructing behavior (Gertler and Hubbard, 1988). This would make strong firm-level corporate governance less important.

In Panel B of Table 4.1, the correlation statistics between the CGQ index and the four different sub indices are reported. Board, Compensation, Takeover and Audit are all positively correlated with the CGQ index, but the

21 Please refer to wwwissproxy.com for the exact methodology. 
coefficient of Takeover is close to zero. Moreover, Takeover is negatively related with the other sub-indices. This makes intuitive sense, as firms have to comply with regulations, a variety of committees and public scrutiny regarding compensation schemes, board structure and audit practices, whereas they can decide more freely on the adoption of takeover provisions.

Panel $\mathrm{C}$ of Table 4.1 provides the summary statistics for the CGQ index of REITs relative to their index peers. ${ }^{22}$ The increasing governance scores show that firm-level corporate governance in REITs has strongly improved over the sample period. We also study how governance scores differ between sectors in the REIT sample and find that diversified REITs score lowest (score: 41.1), whereas industrial and office REITs score highest (scores: 66.1 and 63.1 respectively). This indicates that there is more managerial freedom in diversified REITs and investors might therefore face higher agency costs. This is in line with evidence that property companies with a property focus outperform diversified property companies (Boer, et al. 2005, Eichholtz, et al. 2001).

22 The index governance scores of REITS are relative to four different indices: CGO Universe, Russell $3000, S \& P 400$ and S\&P500. 
Table 4.1

Descriptive Statistics

Corporate Governance Quotient Index

\begin{tabular}{|c|c|c|c|c|}
\hline \multicolumn{5}{|c|}{ Panel A. CGQ Index Scores - All Industries } \\
\hline \multirow{2}{*}{\multicolumn{3}{|c|}{ Top -5}} & \multicolumn{2}{|c|}{2005} \\
\hline & & & CGQ & SD \\
\hline \multicolumn{2}{|l|}{ Real Estate } & & 64.5 & 28.6 \\
\hline \multicolumn{2}{|l|}{ Utilities } & & 63.1 & 28.2 \\
\hline \multicolumn{2}{|l|}{ Banks } & & 60.2 & 26.7 \\
\hline \multicolumn{2}{|c|}{ Pharmaceuticals \& Biotechnology } & & 56.7 & 26.0 \\
\hline \multicolumn{2}{|c|}{ Insurance } & & 54.5 & 28.2 \\
\hline \multicolumn{5}{|c|}{ Bottom - 5} \\
\hline \multicolumn{2}{|c|}{ Hotels, Restaurants and Leisure } & & 46.4 & 27.5 \\
\hline \multicolumn{2}{|c|}{ Telecommunication Services } & & 42.4 & 27.1 \\
\hline \multicolumn{2}{|c|}{ Household \& Personal Products } & & 41.0 & 26.2 \\
\hline \multicolumn{2}{|c|}{ Food Beverage \& Tobacco } & & 38.0 & 30.1 \\
\hline \multicolumn{2}{|c|}{ Media } & & 35.6 & 29.8 \\
\hline \multicolumn{5}{|c|}{ Panel B. Correlations Between Subindices } \\
\hline \multirow{2}{*}{\multicolumn{2}{|c|}{$\begin{array}{cc} & \text { CGQ } \\
\text { Board } & 0.78^{* * *}\end{array}$}} & Board & Compensation & Takeover \\
\hline & & & & \\
\hline Compensation & $0.52 * * *$ & $0.24^{* * *}$ & & \\
\hline Takeover & $0.04^{* * *}$ & $-0.11^{* * *}$ & $-0.08^{* * *}$ & \\
\hline Audit & $0.44^{* * *}$ & $0.36^{* * *}$ & $0.10^{* * *}$ & $-0.05^{* * *}$ \\
\hline \multicolumn{5}{|c|}{ Panel C. CGO Index Scores - Real Estate } \\
\hline & 2003 & 2004 & 2005 \\
\hline & Governance index & CGO & CGQ & CGO \\
\hline \multicolumn{2}{|l|}{ Mean } & 50.5 & 54.6 & 64.5 \\
\hline \multicolumn{2}{|l|}{ Standard deviation } & 26.8 & 29.3 & 28.6 \\
\hline \multicolumn{5}{|l|}{ Subindex means } \\
\hline \multicolumn{2}{|l|}{ Board } & 3.1 & 3.5 & 3.4 \\
\hline \multicolumn{2}{|l|}{ Compensation } & 3.4 & 3.5 & 3.4 \\
\hline \multicolumn{2}{|l|}{ Takeover Defenses } & 2.7 & 3.4 & 3.5 \\
\hline \multicolumn{2}{|l|}{ Audit } & 3.5 & 3.8 & 3.3 \\
\hline \multicolumn{2}{|l|}{ Sample Size } & 216 & 210 & 228 \\
\hline
\end{tabular}

Notes: Panel A of Table 4.1 shows the average ISS Corporate Governance Quotient scores for industries ranking in the top-5 and in the bottom-5 of the CGO universe in 2005. The ratings criteria on which the ratings are based are provided in Appendix 4.A. Range of scores is $1-100$. Panel $B$ provides the pairwise correlations between the CGQ index and the four subindices. Panel $C$ shows the CGO Index scores for the sample of U.S. REITs, from 2003 to 2005. Scores on subindices are provided in the lower part of the table, range of subscores is $1-5$. Significance at the 0.10 , 0.05 and 0.01 levels is indicated by ${ }^{*},{ }^{* *}$ and ${ }^{* * *}$ respectively. 


\title{
4.4 Empirical Analysis: Firm Value and Operating Performance
}

\author{
4.4.1 Full sample: Governance, Firm Value and Operating Performance
}

It has been well-established in the literature that governance indices can explain part of the cross-sectional variation in firm valuation. Among others, Brown and Caylor (2006), Core et al. (2006), Durnev and Kim (2005), GIM, and La Porta et al. (2002) find that companies with high governance ratings exhibit higher valuation as compared to their counterparts with a weak governance structure, indicating that investors incorporate ex-ante expectations on corporate governance in the stock price. A positive relation between corporate governance and operating measures of performance, such as return on equity, the net profit margin and sales growth, is less consistently documented.

We test the influence of corporate governance on firm value by regressing Tobin's $Q$ (measured at time $t$ ), on the lagged CGQ index (measured at time $t-1$ ). Tobin's $Q$ is defined as the market value of assets divided by the replacement costs of the assets. The market value of the assets is the sum of the book value of the assets and the market value of equity minus the book value of equity and deferred taxes. We assume that the replacement costs of the assets are the same as the book value of the assets.

Although estimating the effect of changes in the CGQ index on changes in firm value would establish a stronger causal link, the data force us to use a levels approach, as the time series over which the CGO index is available covers a rather short time period and the CGQ index does not frequently change over time. A potential caveat is thus that our estimation possibly suffers from reverse causality, i.e. endogeneity. Firms with a higher market valuation could well be likely to establish a stronger governance structure, as they have a regular need for outside financing and thus want to signal good governance practices to obtain a lower cost of capital (Klapper and Love, 2004). Again, the limited time period over which data is available does not allow for solving the problem of endogeneity in the optimal way. Instead, we mitigate the reverse causality issue by including appropriate control variables in our estimation, an approach that is commonly used in the literature. ${ }^{23}$ First, following Shin and Stulz (2000), we include the natural logarithm of the firm's book value of assets and the firm's age. Second, we include a control variable for the debt-to-equity ratio, measured by the ratio of debt to total capital, to capture the effect of past financing decisions (Black, et al. 2006). Third, we include the current and lagged value of return on equity to account for the influence of performance on firm valuation.

Following the analysis of corporate governance and firm value, we investigate whether a high corporate governance rating also enhances operational performance, following more efficient operations. Therefore, we study the impact of the CGQ index on four different measures of operating efficiency. Following GMM, we select return on equity (ROE), the net profit margin (NPM), and 5-year sales growth (SALES). Additionally, we use return on assets (ROA), as this measure might be preferable to ROE due to its more desirable distributional properties and because it is not affected by leverage and other items (Core, et al. 2006). For the analysis on the REIT sample, we substitute SALES by the average 3-year growth in funds from operations per share (FFO). FFO is a widely recognized performance measure in the real estate industry, calculated by adding depreciation and amortization expenses back to earnings. In all estimations, we follow Core et al. (2006) and GIM and include

23 See for example Bauer, Guenster and Otten (2004), Black et al. (2006), Drobetz et al. (2004) and Klapper and Love (2004). 
the book-to-market (BM) value as a control variable. ${ }^{24}$ In the estimation with FFO as the dependent variable, we also include firm size (SIZE) in the model, proxied by the log of the book value of assets. We control for industry effects by including industry dummies in the regressions, using the industry classifications of ISS. ${ }^{25}$

Table 4.2 presents the summary statistics of a selection of financial and accounting variables for year 2005 and their correlations with the CGQ index. The average firm value in our sample is comparable to GIM, but the average operating performance is slightly lower than for example Core et al. (2006), which might be due to the inclusion of a substantial number of small caps in our sample. The correlation statistics show that firms with a high governance score tend to be well-performing large firms with low leverage. The correlation coefficient between Tobin's $Q$ (BM-ratio) and the CGO score is negative (positive), which is contrary to expectations. However, the preliminary figures in the table omit important determinants from the analysis.

\section{Table 4.2}

Descriptive Statistics

Financial Characteristics Full Sample (2005)

\begin{tabular}{lcccc}
\hline Variable & Mean & Median & SD & Correlation with CGO \\
\hline Tobin's 0 & 2.16 & 1.52 & 1.89 & $-0.06^{* * *}$ \\
ROE & 2.94 & 9.37 & 53.46 & $0.01^{* * *}$ \\
ROA & 1.84 & 3.83 & 25.30 & $0.12^{* * *}$ \\
Size $($ log & 2.56 & 2.59 & 1.02 & $0.37^{* * *}$ \\
Leverage & 0.69 & 0.02 & 3.24 & $-0.18^{* * *}$ \\
BM-ratio & 0.43 & 0.43 & 0.56 & $0.01^{* * *}$ \\
\hline
\end{tabular}

Notes: Table 4.2 provides full sample summary statistics for a selection of financial and accounting measures in 2005. The last column provides the pairwise correlation for each of the variables with the CGO index. Significance at the 0.10,0.05 and 0.01 levels is indicated by *, "** and ${ }^{* * *}$ respectively.

We estimate OLS regressions to study the effect of corporate governance on firm value. Besides that, we estimate the models with curtailed regressions ( $1 \%$ at both sides) to reduce the influence of outliers and obtain similar results. Some comparable studies estimate yearly regressions and consequently calculate a FamaMacBeth (1973) mean and t-statistic. This approach partially avoids the problems of serial correlation and cross-sectional dependence. However, our short time-series does not allow for the same methodology, so we exploit our dataset in a pooled setup. Ideally, we would estimate the panel in a firm fixed-effects setting with time-varying coefficients, but the CGO index does not change frequently over time, so the estimation will not

24 We acknowledge that the equations estimating the effect of corporate governance on operating performance might be extended with more control variables. However, for reasons of comparability, we stick to methods used in the existing literature.

25 Industry classifications of ISS are similar to the more commonly used Fama and French (1997) industry classifications. 
lead to proper results due to identification of the governance coefficient based on minor changes. Moreover, we expect that cross-sectional variation in corporate governance will be the driver of our results, rather than the small changes in governance over time (Zhou, 2001). Therefore, we use a time fixed-effects approach and adjust standard errors to account for serial correlation within the firm-cluster, following Rogers' (1993) method.

The regression results are presented in Table 4.3. Panel A shows the results for firm value, whereas Panel B shows the results for operating performance. Coefficients of time and industry dummies are omitted. We first estimate the model with the overall CGO index and subsequently use the four governance subscores, Audit, Compensation, Takeover and Board, respectively. In Panel $A$, the coefficients on the CGO index and its subscores are significantly positive, except for the 'takeover' subscore. In terms of economic significance, the effects of governance on firm value are strong: a one point increase in the overall CGO index (range $1-100$ ) leads to a $0.3 \%$ increase in the median Tobin's 0 , whereas a one point increase in the CGO sub-indices (range $1-5$ ) leads to a $3 \%$ to $5 \%$ percent increase in the median Tobin's 0 . These findings indicate that firms with high rated corporate governance standards are valued higher by the market.

The non-significant effect of the governance sub-index 'takeover' on firm value indicates that investors either not care about or do not pay attention to the adoption of anti-takeover provisions, contrasting investor scrutiny regarding executive compensation or board structure. Finally, the signs on the control variables are in line with expectations: firm value is higher for young and small companies, with strong past performance.

Although we exploit a database that has not been widely used in corporate governance studies hitherto, our results for the full sample of 5000 firms confirm previous findings by for example Brown and Caylor (2006). Durnev and Kim (2005), GIM and Klapper and Love (2004). This contrasts criticism on empirical governanceperformance studies that findings are often index-specific (Sonnenfeld, 2004).

Panel B shows several interesting findings, which are estimated using median (least-absolute-deviation) regressions to reduce the influence of outliers, following Core et al. (2006), GIM and Klapper and Love (2004). First, we document that the CGQ index is positively related to the performance measures return on equity and the net profit margin, which is in line with GIM, who find evidence that firms with weaker shareholder rights have weaker operating performance. However, the results of GIM lack statistical significance, whereas our results are statistically strong. With respect to return on assets, the significantly positive coefficient is similar to Core et al. (2006) and Klapper and Love (2004), who find a significantly positive relation between return on assets, the GIndex and the CLSA index respectively. Regarding economic significance of our findings, we note that the relation between the governance index on the one hand, and the return on equity and net profit margin on the other hand, are particularly strong: a one point increase in the CGO index leads to a $2.7 \%(2.2 \%)$ increase in return on equity (net profit margin). For return on assets, the economic significance of the coefficient is lower, but still considerable.

The sign on the control variable is in line with expectations: operating performance is negatively related to the book-to-market value. For panel $B$, the goodness of fit of the model is represented by the pseudo R-squared. At first sight, the figures seem to be quite low, which can be partially attributed to the method we use. Furthermore, Brown and Caylor (2006) also use the CGQ index in combination with the same methodological setup and document similar explanatory power for their models. 
Table 4.3

Regression Results

Corporate Governance, Firm Value and Operating Performance: Full Sample (dependent variables: Tobin's $Q$ and operating performance)

\begin{tabular}{|c|c|c|c|c|c|}
\hline \multicolumn{6}{|c|}{ Panel A: Tobin's 0-All Industries } \\
\hline & (1) & (2) & (3) & (4) & (5) \\
\hline \multirow[t]{2}{*}{ CGQ Index } & 0.004 & & & & \\
\hline & $(5.25)^{* * *}$ & & & & \\
\hline \multirow[t]{2}{*}{ Audit Index } & & 0.057 & & & \\
\hline & & $(3.66)^{* * *}$ & & & \\
\hline \multirow[t]{2}{*}{ Compensation Index } & & & 0.046 & & \\
\hline & & & $(2.99)^{* * *}$ & & \\
\hline \multirow[t]{2}{*}{ Takeover Index } & & & & 0.021 & \\
\hline & & & & $(1.35)$ & \\
\hline \multirow[t]{2}{*}{ Board Index } & & & & & 0.069 \\
\hline & & & & & $(3.69)^{* * *}$ \\
\hline \multirow[t]{2}{*}{ Size $(\log )$} & -0.393 & -0.359 & -0.359 & -0.341 & -0.382 \\
\hline & $(7.57)^{* * *}$ & $(7.20)^{* * *}$ & $(7.10)^{* * *}$ & $(6.94)^{* * *}$ & $(7.36)^{* * *}$ \\
\hline \multirow[t]{2}{*}{ Age (log) } & -0.160 & -0.111 & -0.146 & -0.117 & -0.141 \\
\hline & $(2.08)^{* *}$ & $(1.47)$ & $(1.94)^{*}$ & $(1.55)$ & $(1.85)^{*}$ \\
\hline \multirow[t]{2}{*}{ ROE } & 0.001 & 0.001 & 0.001 & 0.001 & 0.001 \\
\hline & $(1.88)^{*}$ & $(1.65)^{*}$ & $(1.67)^{*}$ & $(1.65)^{*}$ & $(1.66)^{*}$ \\
\hline \multirow[t]{2}{*}{ ROEt-1 } & 0.001 & 0.001 & 0.001 & 0.001 & 0.001 \\
\hline & $(1.80)^{*}$ & $(1.79)^{*}$ & $(1.80)^{*}$ & $(1.79)^{*}$ & $(1.79)^{*}$ \\
\hline \multirow[t]{2}{*}{ Leverage } & 0.002 & 0.002 & 0.002 & 0.002 & 0.002 \\
\hline & $(0.28)$ & $(0.27)$ & $(0.28)$ & $(0.28)$ & $(0.27)$ \\
\hline \multirow[t]{2}{*}{ Constant } & 2.895 & 2.765 & 2.854 & 2.810 & 2.854 \\
\hline & $(14.39)^{* * *}$ & $(13.65)^{* * *}$ & $(13.92)^{* * *}$ & $(12.22)^{* * * *}$ & $(14.31)^{* * *}$ \\
\hline Year Fixed Effects & $Y$ & $Y$ & $Y$ & $Y$ & Y \\
\hline Industry Fixed Effects & $Y$ & Y & $Y$ & $Y$ & Y \\
\hline Sample Size & 11572 & 11572 & 11572 & 11572 & 11572 \\
\hline Adj $R^{2}$ & 0.27 & 0.27 & 0.27 & 0.27 & 0.27 \\
\hline
\end{tabular}


Table 4.3 (continued)

\begin{tabular}{lcccc}
\hline \multicolumn{5}{l}{ Panel B: Operating Performance - All Industries } \\
& ROE & ROA & Sales Growth & NPM \\
\hline CGO Index & 0.027 & 0.006 & 0.000 & 0.022 \\
& $(8.56)^{* * *}$ & $(5.17)^{* * *}$ & $(0.08)$ & $(9.16)^{* * *}$ \\
BM-Ratio (log) & -17.023 & -4.649 & -7.885 & -5.229 \\
& $(63.50)^{* * *}$ & $(52.32)^{* * *}$ & $(22.12)^{* * *}$ & $(25.52)^{* * *}$ \\
Intercept & 3.295 & 3.477 & 0.974 & -1.654 \\
& $(3.39)^{* * *}$ & $(10.48)^{* * *}$ & $(0.75)$ & $(2.20)^{* *}$ \\
Year Fixed Effects & $Y$ & $Y$ & $Y$ & $Y$ \\
Industry Fixed Effects & $Y$ & $Y$ & $Y$ & $Y$ \\
Median Adjusted & $Y$ & $Y$ & $Y$ & $Y$ \\
Sample Size & & & & \\
Pseudo R & 11572 & 11572 & 11572 & 11572 \\
\hline
\end{tabular}

Notes: Panel A of Table 4.3 presents the results of the OLS regression of Tobin's $Q$ on the CGO index and control variables. In column (1), the CGO index is the main explanatory variable, whereas the results columns (2) to (5) are estimated using the subindexes Audit, Compensation. Takeover. and Board, respectively. Tobin's $Q$ is defined as the book value of assets plus the market value of equity minus the book value of equity and deferred taxes, the control variables include current and lagged return on equity (ROE), the natural logarithm of the book value of assets (Size), the natural logarithm of age, the debt ratio (Leverage), year dummies and industry dummies (based on ISS industry classification). Panel 8 provides the estimation results of the median regressions for return on equity (ROE), return on assets (ROA), the sales growth, and the net profit margin (NPM) on the CGO index, the natural logarithm of the book-to-market ratio (BM), year and industry dummies. (-statistics based on Rogers (1993) clustered standard errors are in parentheses. Significance at the 0.10,0.05 and 0.01 levels is indicated by * ** and *** respectively.

\subsubsection{REITs: Governance, Firm Value and Operating Performance}

The results for the complete CGO dataset confirm existing empirical evidence that well-structured corporate governance leads to better operating performance, even though the results are based on an index that has not been widely used in corporate governance research before. Moreover, the market seems to value strong firm-level corporate governance and incorporates this information ex-ante, leading to higher valuations for well-governed firms. For REITs, the distinct legal environment leads to two competing hypotheses: under the substitution hypothesis, we argue that the naturally strong institutional setting in which REIT managers operate makes it less costly to deviate from the optimal corporate governance structure. As investors especially value strong corporate governance mechanisms in weak institutional settings (Durnev and Kim, 2005, Klapper and Love, 2004), a weak relation between the CGO index and REIT value can be expected. With respect to operating performance, strong firm-level corporate governance cannot enforce REIT managers to enhance operating performance to the same extent as compared to firms operating in a non-restricted legal environment, so the relation between corporate governance and operating performance is expected to be weak as well.

On the other hand, the depreciation expense is excluded from the distribution requirement, which leaves REIT management with discretionary cash flows (Kallberg, Liu and Srinivasan, 2003). Moreover, the restrictions of the REIT structure on ownership concentration might reduce the pressure of the market for corporate control. Under the complement hypothesis, firm-level corporate governance mechanisms are an important addition to the legal setting in which REITs operate. Therefore, one would expect the relation between corporate governance and firm value to be similar to other industries. With respect to operating performance, stronger firm-level corporate governance would lead to less managerial entrenchment and thus more efficient operations. 
To test the hypotheses, we repeat the analysis of the previous section, but instead of analysing the complete CGO dataset, we now focus on the REIT sample. We replace industry dummies by dummies that correspond to REIT investment focus (diversified, industrial, mortgage, office, residential, retail and other). Data is collected from SNL. Table 4.4 reports the results, where Panel A presents the results for firm value and Panel B presents the results for operating performance. Coefficients of time and investment focus dummies are omitted. We first estimate all models with the overall CGO index and subsequently use the four sub-indices. Contrasting the full sample results, we find no evidence that REITs with higher corporate governance ratings have a higher firm value. This supports the substitution hypothesis: the strong institutional setting in which REITs operate seems to reduce the importance of firm-level corporate governance for investors. Therefore, a lower corporate governance rating does not directly lead to lower firm value, which is in line with findings by Durnev and Kim (2005) and Klapper and Love (2004).

In Panel B of Table 4.4, we document no significant evidence on the relation between corporate governance and operating performance in REITs. In line with evidence on firm value, this is contrasting the full sample results, where we documented that lower corporate governance scores lead to lower operating performance. We can explain the lack of a significant relation between corporate governance and operating performance in RElTs by the restricted environment in which REIT managers operate. The obligation to obtain at least $75 \%$ of income from real estate investments limits operational freedom, so managers can influence operating performance to a lesser extent, independent of the structure of corporate governance.

Related to the real estate literature, our results are not only in line with, but also add to the findings of Hartzell et al. (2006), as we find similar results while using an aggregate governance index rather than a combination of individual governance measures. However, our results are contrasting several previous studies that have documented a significantly positive relation between firm value and managerial ownership (Capozza and Seguin, 2003, Han, 2006) and between firm value and identity of management (Capozza and Seguin, 2000). This inconsistency can be explained in four ways. First, the CGQ index includes insider holdings in the ratings criteria, but this is just one element of the total governance index. Moreover, the presence of director shareholdings rather than the variation in the level of insider holdings is reflected. Second, Agrawal and Knoeber (1996) show that the effect of insider shareholdings on firm performance is only present when included as the single governance mechanisms. The effect disappears when other corporate control mechanisms are included in the regression. This indicates that alternative corporate governance measures might be interdependent, and explains the inconsistency between our results and Capozza and Seguin $(2000,2003)$ or Han (2006). Third, Capozza and Seguin (2000) document that REITs with external management have less cash flow available for distribution as compared to REITs with internal management. Although the identity of management is not specifically addressed in the CGO index, we expect the influence of external management on operating performance to be limited in our sample, as the number of REITs with this structure has decreased dramatically over the past few years. Fourth, we execute our study during a more recent period and we use a larger sample of RElTs than comparable studies.

The REIT results at first sight show that the structure of corporate governance does not matter for performance. We argue that this result might be due to a 'REIT effect': the distinct legal setting in which REITs operate limits managerial freedom through the obligation to pay out at least $90 \%$ of net earnings and through operational restrictions. Deviating from the optimal governance structure is therefore less costly. However, there are alternative explanations for this REIT effect. First, there is considerable variation in the discretionary cash flow available to REIT managers. Therefore, corporate governance might not be a driver of performance when 
Corporate Governance and Sustainability in Global Property Markets

examining the cross-section of REITs, but only for REITs that are awash with cash. Second, the lack of a relation between corporate governance and performance in our sample of REITs might be inherent to the nature of the product - real estate. Property companies are highly transparent, as the individual properties in the portfolio are relatively easy to value. The REIT industry is very capital-intensive as the asset base of these companies mainly consists of fixed assets, and expenses on intangible assets such as for example marketing and R\&D are limited. Therefore, there might be less scope for agency problems. Third, our results might be driven by the specific governance index that we exploit. 
Table 4.4

Regression Results

Corporate Governance, Firm Value and Operating Performance: REITs (dependent variables: Tobin's $\mathrm{Q}$ and operating performance)

\begin{tabular}{|c|c|c|c|c|c|}
\hline \multicolumn{6}{|c|}{ 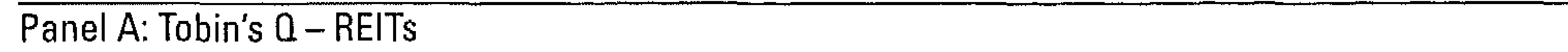 } \\
\hline & $(1)$ & (2) & (3) & (4) & (5) \\
\hline \multirow[t]{2}{*}{ CGO Index } & 0.001 & & & & \\
\hline & (1.32) & & & & \\
\hline \multirow[t]{2}{*}{ Audit Index } & & -0.008 & & & \\
\hline & & $(0.47)$ & & & \\
\hline \multirow[t]{2}{*}{ Compensation Index } & & & 0.002 & & \\
\hline & & & $(0.10)$ & & \\
\hline \multirow[t]{2}{*}{ Takeover Index } & & & & 0.016 & \\
\hline & & & & $(0.78)$ & \\
\hline \multirow[t]{2}{*}{ Board Index } & & & & & 0.037 \\
\hline & & & & & $(1.33)$ \\
\hline \multirow[t]{2}{*}{ Size $(\log )$} & -0.119 & -0.102 & -0.104 & -0.101 & -0.122 \\
\hline & $(1.75)^{*}$ & $(1.57)$ & $(2.30)^{* *}$ & $(1.56)$ & $(1.65)$ \\
\hline \multirow[t]{2}{*}{ Age (log) } & 0.258 & 0.255 & 0.257 & 0.264 & 0.246 \\
\hline & $(2.11)^{* *}$ & $(2.04)^{* *}$ & $(3.08)^{* * *}$ & $(2.11)^{* *}$ & $(2.08)^{* *}$ \\
\hline \multirow[t]{2}{*}{ ROE } & 0.001 & 0.001 & 0.001 & 0.001 & 0.001 \\
\hline & $(4.42)^{* * *}$ & $(4.43)^{* * *}$ & $(2.26)^{* *}$ & $(4.28)^{* * *}$ & $(4.72)^{* * *}$ \\
\hline \multirow[t]{2}{*}{$\mathrm{ROE}_{1-1}$} & 0.000 & 0.000 & 0.000 & 0.000 & 0.000 \\
\hline & $(6.53)^{* * *}$ & $(7.23)^{* * *}$ & $(8.64)^{* * *}$ & $(7.09)^{* * *}$ & $(5.71)^{* * *}$ \\
\hline \multirow[t]{2}{*}{ Leverage } & -0.042 & -0.043 & -0.042 & -0.043 & -0.042 \\
\hline & $(1.88)^{*}$ & $(1.91)^{*}$ & $(2.04)^{* *}$ & $(1.88)^{*}$ & $(1.94)^{*}$ \\
\hline \multirow[t]{2}{*}{ Constant } & 1.453 & 1.494 & 1.465 & 1.375 & 1.422 \\
\hline & $(7.55)^{* * *}$ & $(7.66)^{* * *}$ & $(9.36)^{* * *}$ & $\langle 6.05\rangle^{* * *}$ & $(8.03)^{* * *}$ \\
\hline Year Fixed Effects & Y & Y & $Y$ & $Y$ & $Y$ \\
\hline Sector Fixed Effects & $Y$ & $Y$ & $Y$ & $Y$ & Y \\
\hline Sample Size & 509 & 509 & 509 & 509 & 509 \\
\hline Pseudo $\mathrm{R}^{2}$ & 0.13 & 0.13 & 0.13 & 0.13 & 0.13 \\
\hline
\end{tabular}


Table 4.4 (continued)

\begin{tabular}{lcccc}
\hline Panel B: Operating Performance - REITs & & & \\
& ROE & ROA & FFO growth & NPM \\
\hline CGO Index & -0.015 & 0.001 & -0.001 & -0.008 \\
& $(1.26)$ & $(0.23)$ & $(1.60)$ & $(0.23)$ \\
BM-ratio (log) & -10.842 & -2.343 & -0.091 & -3.313 \\
& $(9.47)^{* * *}$ & $(4.96)^{* * *}$ & $(4.68)^{* * *}$ & $(0.94)$ \\
Size (log) & & & 0.036 & \\
& & & $(4.55)^{* * *}$ & \\
Constant & 5.395 & 5.086 & -0.072 & 16.912 \\
& $(6.05)^{* * *}$ & $(12.89)^{* * *}$ & $(3.00)^{* * *}$ & $(5.33)^{* * *}$ \\
Year Fixed Effects & $Y$ & $Y$ & $Y$ & $Y$ \\
Sector Fixed Effects & $Y$ & $Y$ & $Y$ & $Y$ \\
Median Adjusted & $Y$ & $Y$ & $Y$ & $Y$ \\
& & & & \\
Sample Size & 509 & 509 & 509 & 509 \\
Pseudo R & 0.01 & 0.03 & 0.02 & 0.04 \\
\hline
\end{tabular}

Notes: Panel A of Table 4.4 presents the OLS regression results for the REIT sample of Tobin's $Q$ on the CGQ index and control variables. In column (1), the CGO index is the main explanatory variable, whereas columns (2) to (5) are estimated with subindexes Audit, Compensation. Takeover and Board respectively. Tobin's $Q$ is defined as the book value of assets plus the market value of equity minus the book value of equity and deferred taxes. The control variables include current and lagged return on equity (ROE), the log of the book value of assets (Size), the log of age and the debt ratio (Leveragel, year dummies and sector dummies. Panel B provides the estimation results of the median regression. with return on equity (ROE), return on assets (ROA), and 3-year growth in funds from operations per share (FFO growth) on the CGO index, as dependent variables respectively. We include the natural logarithm of the book-to-market ratio (BM), size, year dummies and sector dummies as control variables. $t$-statistics based on Rogers (1993) clustered standard errors are in parentheses. Significance at the 0.10, 0.05 and 0.01 levels is indicated by ${ }^{*},{ }^{* *}$ and ${ }^{* * *}$ respectively.

\subsubsection{Control Samples}

To investigate the alternative explanations for the REIT effect, we conduct three robustness checks. First, we create a sample based on a selection of capital-intensive companies. To this end, we match the REIT sample with companies that have a comparable corporate real estate ratio. Second, to test whether our results are driven by the specifics of the CGQ index, we repeat our analysis with the REITs in the G-Index, which was first constructed and exploited by GIM and later used by for example Core et al. (2006) and, specifically for the real estate sector, by Bianco et al. (2007). Third, we split the REIT sample in a selection that is cash constrained and a selection that is cash rich. 


\subsubsection{Firms with High Corporate Real Estate Ratios}

REITs are typically companies with a relatively large percentage of fixed assets. Gertler and Hubbard (1988) show that companies with a concentration of 'hard' capital have fewer possibilities to engage in value-destructing behavior, which might be an alternative explanation to our findings. So, as a first robustness check, we construct a control sample that consists of companies with high corporate real estate ratios (CRERs). Following the methodology of Brounen and Eichholtz (2005), this ratio quantifies relative real estate ownership in the following way:

CRER $=\frac{P P E}{\text { Total Assets }}$

Where PPE represents Compustat item 'Property, Plant and Equipment' and Total Assets is the book value of a firm's total assets. We exclude REITs from the total CGO sample, sort the remainder on their CRERs and match it to the REIT sample on a yearly basis. After collecting the necessary accounting data, this leads to a control sample of 545 observations (firm-years). To test whether our results for REITs can be explained by the relatively high share of fixed assets, we estimate regressions similar to the analysis in sections 4.4.1 and 4.4.2. Again, we include industry dummies to correct for industry effects. For the models with operating measures as the dependent variables, we estimate median (least-absolute-deviation) regressions to correct for outliers.

Table 4.5 presents the results. Panel A shows that the average CGQ score of companies in the control sample is 50.5. The average CGQ score for the control sample ranges from 49.4 in 2003 to 54.1 in 2005 (not reported), which is substantially lower as compared to the average CGO score for REITs, which is 64.5 in 2005 (see Table 4.1). In Panel B, we find that the CGQ index is significantly and positively related to firm value and operating performance, except for the performance measure 'sales growth'. This is similar to the results for the complete sample. The coefficients are economically significant as well: a one point increase in the CGO index leads to a $0.2 \%$ increase in the median Tobin's $Q$ and to a $3.4 \%$ increase in ROE.

The presence of a relation between corporate governance and performance in our control sample of companies with a high CRER makes it unlikely that the lack of findings regarding the governance-performance relation in the real estate sector are the result of the high percentage of fixed assets in REITs. This confirms the possible existence of a 'REIT effect' in explaining the lack of a relation between firm-level corporate governance and performance in U.S. REITS. 
Corporate Governance and Sustainability in Global Property Markets

Table 4.5

Descriptives and Regression Results

Control Sample: Firms with High Corporate Real Estate Ratios

\begin{tabular}{lcc}
\hline Panel A: Descriptives Control Sample & Mean & SD \\
\hline CGO & 50.47 & 27.89 \\
Tobin's 0 & 1.33 & 0.53 \\
\hline
\end{tabular}

\begin{tabular}{|c|c|c|c|c|c|}
\hline \multicolumn{6}{|c|}{ Panel B: Tobin's 0 and Operating Performance } \\
\hline & (1) & (2) & $(3)$ & (4) & (5) \\
\hline \multirow[t]{2}{*}{ CGO Index } & 0.003 & 0.034 & 0.012 & -0.003 & 0.022 \\
\hline & $(1.89)^{*}$ & $(3.69)^{* * *}$ & $(1.84)^{*}$ & $(0.13)$ & $(3.15)^{* * *}$ \\
\hline \multirow[t]{2}{*}{ BM-ratio (log) } & & -18.686 & -4.632 & -8.659 & -5.528 \\
\hline & & $(20.00)^{* * *}$ & $(6.94)^{* * *}$ & $(3.88)^{* * *}$ & $(8.23)^{* * *}$ \\
\hline \multirow[t]{2}{*}{ Size (log) } & -0.217 & & & & \\
\hline & $(2.99)^{* * *}$ & & & & \\
\hline \multirow[t]{2}{*}{ Age (log) } & 0.098 & & & & \\
\hline & $(0.75)$ & & & & \\
\hline \multirow[t]{2}{*}{ ROE } & -0.000 & & & & \\
\hline & $(0.44)$ & & & & \\
\hline \multirow[t]{2}{*}{$R O E_{r-1}$} & 0.001 & & & & \\
\hline & $(0.41)$ & & & & \\
\hline \multirow[t]{2}{*}{ Leverage } & -0.113 & & & & \\
\hline & $(2.43)^{* *}$ & & & & \\
\hline \multirow[t]{2}{*}{ Constant } & 0.939 & 3.626 & 3.732 & -0.510 & 3.313 \\
\hline & $(4.73)^{* * *}$ & $(13.82)^{* * *}$ & (1.59) & $(5.18)^{* * *}$ & (1.38) \\
\hline Year Fixed Effects & Y & Y & Y & Y & Y \\
\hline Industry Fixed Effects & Y & Y & $Y$ & Y & $Y$ \\
\hline Median Adjusted & N & Y & $Y$ & $Y$ & $Y$ \\
\hline Sample Size & 545 & 545 & 545 & 545 & 545 \\
\hline $\operatorname{Adj} R^{2}$ & 0.17 & & & & \\
\hline Pseudo $\mathrm{R}^{2}$ & & 0.11 & 0.13 & 0.12 & 0.02 \\
\hline
\end{tabular}

Notes: The control sample used in Table 4.5 is constructed by matching the REIT sample with regular corporations that have a similar corporate real estate ratio (CRER). Panel A shows the descriptives. In Panel B, column (1) shows the results of the OLS regression of Tobin's $Q$ on the CGO index and control variables. The control variables include current and lagged return on equity (ROE), the natural logarithm of the book value of assets (Size), the natural logarithm of age, the debt ratio (Leverage), year dummies and industry dummies. Tobin's $Q$ is defined as the book value of assets plus the market value of equity minus the book value of equity and deferred taxes. Columns (2) through (5) provide the estimation results of the median regressions for return on equity (ROE), return on assets (ROA), the sales growth and net profit margin (NPM) on the CGO index and the natural logarithm of the book-to-market ratio (BM), year dummies and industry dummies. t-statistics based on Rogers (1993) firm clustered standard errors are in parentheses. Significance at the 0.10,0.05 and 0.01 levels is indicated by * ** and *** respectively. 


\subsubsection{REITs in G-Index Sample}

In Sections 4.4.1 and 4.4.2, we frequently compare our results to those of Core et al. (2006) and GIM. These authors derive their governance index, which is the so-called G-Index, from publications of the Investor Responsibility Research Center. However, the G-Index includes takeover provisions only. One could argue that our findings cannot be compared with GIM directly, as the CGQ index incorporates a much broader range of corporate governance mechanisms. As a robustness check, we therefore repeat our governance-performance analysis of REITs with the G-Index. This additional analysis has parallels with Bianco et al. (2007). We collect data from RiskMetrics (formerly IRRC), which contains bi-annual ratings on approximately 2,000 U.S. companies. We select all REITs in the sample years 2004 and 2006 and collect financial information from Compustat. This leads to a total sample of 113 observations (firm-years).

Panel A of Table 4.6 shows the average number of takeover provisions in place for the REIT sample and the total $\mathrm{G}$-Index sample, respectively. We note that the $\mathrm{G}$-Index has a range from 1 to 24 , where each point represents a takeover provision. So, a lower score implies less restricted shareholder rights. The descriptive statistics show that REITs have less takeover provisions in place as compared to the full sample, which means that shareholder rights are relatively strong in REITs. In Panel B, we present the results of the regression analysis, in which we use Tobin's Q, ROE, ROA and FFO growth as dependent variables respectively. Contrasting Core et al. (2006) and GIM, we do not find a statistically significant relation between the G-Index, firm value and operating performance. These findings confirm the results we documented for REITs in the previous section, where we exploited the CGO index. The lack of a relation between the G-Index, firm value and operating performance supports the findings of Bianco et al. (2007), who argue that a governance index solely based on takeover provisions is not a suitable governance proxy for the real estate sector. 
Table 4.6

Descriptives and Regression Results

Control Sample: REITs in G-Index

\begin{tabular}{|c|c|c|c|c|}
\hline \multicolumn{5}{|c|}{ Panel A. Descriptives G-Index } \\
\hline & \multicolumn{2}{|c|}{2004} & \multicolumn{2}{|c|}{2006} \\
\hline & Mean & SD & Mean & SD \\
\hline GIM sample & 9.05 & 2.56 & 9.02 & 2.52 \\
\hline REIT sample & 7.67 & 2.11 & 8.34 & 2.21 \\
\hline \multicolumn{5}{|c|}{ Panel B. Tobin's $Q$ and Operating Performance } \\
\hline & (1) & (2) & (3) & (4) \\
\hline \multirow[t]{2}{*}{ G-Index } & 0.009 & -0.460 & -0.234 & -0.038 \\
\hline & $(0.61)$ & $(-0.98)$ & $(-1.33)$ & $(-1.01)$ \\
\hline \multirow[t]{2}{*}{ BM-Ratio } & & -14.415 & -3.707 & -0.316 \\
\hline & & $(-1.51)$ & $(-2.61)^{* *}$ & $(-2.19)^{* *}$ \\
\hline \multirow[t]{2}{*}{ Size $(\log )$} & -0.194 & & & -0.005 \\
\hline & $(-2.78)^{* *}$ & & & $(-0.06)$ \\
\hline \multirow[t]{2}{*}{ Age (log) } & 0.134 & & & \\
\hline & $(0.88)$ & & & \\
\hline \multirow[t]{2}{*}{ ROE } & 0.005 & & & \\
\hline & $(2.77)^{* *}$ & & & \\
\hline \multirow[t]{2}{*}{$\mathrm{ROE}_{\mathrm{i}-1}$} & 0.007 & & & \\
\hline & $(8.56)^{* * *}$ & & & \\
\hline \multirow[t]{2}{*}{ Leverage } & -0.010 & & & \\
\hline & $(-4.72) * * *$ & & & \\
\hline \multirow[t]{2}{*}{ Constant } & 2.659 & 20.860 & 6.755 & 0.431 \\
\hline & $(8.04)^{* * *}$ & $(3.24)^{* * *}$ & $(3.05)^{* * *}$ & $(1.74)^{*}$ \\
\hline Year Fixed Effects & Y & $Y$ & Y & Y \\
\hline Median Adjusted & $N$ & $N$ & N & $N$ \\
\hline Sample Size & 113 & 113 & 113 & 113 \\
\hline Adj $R^{2}$ & 0.28 & 0.07 & 0.07 & 0.09 \\
\hline
\end{tabular}

Notes: Panel A of Table 4.6 presents descriptives of the G-Index for the full sample and the REIT sample. The G-Index is derived from the IRRC data provided by RiskMetrics. Column (1) of Panel B shows the results of the OLS regression of Tobin's $Q$ on the G-Index and control variables. The control variables include current and lagged return on equity (ROE), the natural logarithm of the book value of assets (Sizel, the natural logarithm of age, the debt ratio (Leverage), year dummies and industry dummies. Tobin's O is defined as the book value of assets plus the market value of equity minus the book value of equity and deferred taxes. Columns (2) through (4) provide the estimation results of the median regres. sions for return on equity (ROE), return on assets (ROA), and funds from operations (FFO) on the G-Index and the natural logarithm of the bookto-market ratio (BM), year dummies and industry dummies. t-statistics based on Rogers (1993) firm clustered standard errors are in parentheses. Significance at the $0.10,0.05$ and 0.01 levels is indicated by *, ** and ${ }^{* * *}$ respectively. 


\subsubsection{REITs with High versus Low Payout Ratios}

While the $90 \%$ distribution requirement of REITs is a distinguishing feature, setting them apart from regular corporations, it has been well-documented that this requirement is generally not binding. Among others, Wang et al. (1993) find that the average ratio of dividends to net income is 1.65, whereas Kallberg et al. (2003) document a median ratio of dividends to income of 1.11. This indicates that various expenses - most importantly the depreciation expense - leave discretionary cash flows for REIT managers. REITs that distribute cash flows in excess of the distribution requirement will return to the capital market more frequently and are subject to additional scrutiny of the capital market. In this way, shareholders benefit from the strong institutional setting of REITs and from additional monitoring by the market. Contrasting, shareholders of REITs that retain excess cash flows are more likely to face agency problems as in regular C-corporations, even if these problems probable have a lower magnitude due to the $90 \%$ distribution requirement.

To test this hypothesis, we adapt the payout measure of Wang et al. (1993) by calculating the ratio of dividend payout to free cash flows rather than to net income for each REIT, where the free cash flows include net income before extraordinary items plus the depreciation expense. This accurately determines the availability of discretionary cash flows in REITs. An alternative measure of free cash flow would be FFO, but this measure excludes cash outflows such as amortization and cash inflows such as gains from property sales.

Subsequently, we split the REIT sample on the median in a subsample of 'high payout' REITs and a subsample of 'low payout' REITs. ${ }^{26}$ Panel A of Table 4.7 presents descriptive statistics for both samples. Corporate governance ratings are on average slightly higher for REITs that distribute most of their cash flows, but there are similar levels of cross-sectional variation in both samples.

Panels $B$ and $C$ of Table 4.7 show the subsample results for the $O L S$ regression of Tobin's $Q$ on the governance index and control variables. Coefficients of year dummies, sector dummies and financial variables are omitted. Panel B contains the REITs that distribute most of their free cash flows. For these firms corporate governance is not a significant determinant of firm value. Deviating from the optimal governance structure is less costly, as free cash flow is scarce and managers are frequently scrutinized by the capital market. In Panel $\mathrm{C}$, we show the results for the subsample of REITs that retain more discretionary cash from expenses. In this case, corporate governance does matter for REIT value. The coefficients in columns (2) to (5) indicate that especially a well-structured board is reflected in REIT valuation. Nevertheless, the results for the cash rich REITs still differ considerably from the results that we documented for our sample of 5,000 regular C-corporations, for which the audit and compensation indices were significant as well.

In general, corporate governance is less important for REITs than it is for regular corporations, as the payout restrictions act as a safety net for investors. However, the discretionary cash flows created by the various expenses still offer the opportunity for managerial entrenchment. Indeed, for REITs that do not distribute these additional cash flows, a strong internal corporate governance mechanism seems to be value-enhancing, although other governance mechanisms are less important than for regular corporations. We attribute this to the strong institutional governance setting surrounding REITs: the REIT effect.

26 Ideally, we would also take variables such as growth, REIT type, and capital structure into account when separating the sample, as these are well-documented determinants of dividend payout. However, this is beyond the goal of this robustness check and would lead to analytical problems due to the small subsamples. 
Table 4.7

Descriptives and Regression Results

Corporate Governance and Firm Value in REITs: High vs. Low Payout

\begin{tabular}{|c|c|c|c|c|c|}
\hline \multicolumn{6}{|c|}{ Panel A: Descriptives REIT Subsamples } \\
\hline & & \multicolumn{2}{|c|}{ CGQ Index } & \multicolumn{2}{|c|}{ Tobin's 0} \\
\hline & & Mean & SD & Mean & SD \\
\hline Low Payout & & 50.01 & 30.13 & 1.22 & 0.54 \\
\hline High Payout & & 52.75 & 29.08 & 1.30 & 0.31 \\
\hline \multicolumn{6}{|c|}{ Panel B: RElTs - High Payout Ratio } \\
\hline & $(1)$ & (2) & (3) & (4) & (5) \\
\hline CGQ Index & $\begin{array}{l}0.001 \\
(1.22)\end{array}$ & & & & \\
\hline Audit Index & & $\begin{array}{r}-0.016 \\
(1.26)\end{array}$ & & & \\
\hline Compensation Index & & & $\begin{array}{r}-0.011 \\
(0.79)\end{array}$ & & \\
\hline Takeover Index & & & & $\begin{array}{l}0.008 \\
(0.48)\end{array}$ & \\
\hline Board Index & & & & & $\begin{array}{r}-0.002 \\
(0.13)\end{array}$ \\
\hline Constant & $\begin{array}{l}1.386 \\
(8.12)^{* * *}\end{array}$ & $\begin{array}{l}1.438 \\
(8.34)^{* * *}\end{array}$ & $\begin{array}{l}1.384 \\
\langle 8.09\}^{* * *}\end{array}$ & $\begin{array}{l}1.339 \\
(7.71)^{* * *}\end{array}$ & $\begin{array}{l}1.380 \\
\{8.08\}^{* * *}\end{array}$ \\
\hline Control Variables & Y & Y & Y & Y & Y \\
\hline Year Fixed Effects & Y & Y & Y & $Y$ & Y \\
\hline Sector Fixed Effects & Y & Y & Y & Y & Y \\
\hline Sample Size & 249 & 249 & 249 & 249 & 249 \\
\hline Adj $R^{2}$ & 0.30 & 0.31 & 0.30 & 0.30 & 0.30 \\
\hline
\end{tabular}


Table 4.7 (continued)

\begin{tabular}{|c|c|c|c|c|c|}
\hline \multicolumn{6}{|c|}{ Panel C: REITs - Low Payout Ratio } \\
\hline & (1) & (2) & (3) & (4) & (5) \\
\hline \multirow[t]{2}{*}{ CGO Index } & 0.003 & & & & \\
\hline & $(2.00)^{* *}$ & & & & \\
\hline \multirow[t]{2}{*}{ Audit Index } & & -0.004 & & & \\
\hline & & $(0.15)$ & & & \\
\hline \multirow[t]{2}{*}{ Compensation Index } & & & 0.019 & & \\
\hline & & & (0.59) & & \\
\hline \multirow[t]{2}{*}{ Takeover Index } & & & & 0.022 & \\
\hline & & & & $(0.50)$ & \\
\hline \multirow[t]{2}{*}{ Board Index } & & & & & 0.097 \\
\hline & & & & & $(2.60)^{* * *}$ \\
\hline \multirow[t]{2}{*}{ Constant } & 1.580 & 1.669 & 1.610 & 1.516 & 1.403 \\
\hline & $(6.16)^{* * *}$ & $(6.38)^{* * *}$ & $(5.65)^{* * *}$ & $(3.62)^{* * *}$ & $(6.18)^{* * *}$ \\
\hline Control Variables & $Y$ & Y & Y & Y & Y \\
\hline Year Fixed Effects & Y & Y & Y & Y & Y \\
\hline Sector Fixed Effects & Y & Y & Y & Y & Y \\
\hline Sample Size & 233 & 233 & 233 & 233 & 233 \\
\hline Adj $R^{2}$ & 0.12 & 0.12 & 0.12 & 0.12 & 0.15 \\
\hline
\end{tabular}

Notes: Panel A of Table 4.7 contains the descriptive statistics of the REIT subsamples with low and high payout ratios, respectively. Panel B presents the OLS regression results for the 'high payout' REIT subsample of Tobin's $Q$ on the CGO index and control variables. In column (1), the CGO index is the main explanatory variable, whereas columns (2) to (5) are estimated with subindexes Audit, Compensation, Takeover and Board respectively. Tobin's $Q$ is defined as the book value of assets plus the market value of equity minus the book value of equity and deferred taxes. The control variables include current and lagged return on equity (ROE), the log of the book value of assets (Size), the log of age and the debt ratio (Leverage), year dummies and sector dummies. Panel $C$ provides the OLS regression results for the 'low payout' REIT subsample of Tobin's $Q$ on the CGO index and control variables. t-statistics based on Rogers (1993) clustered standard errors are in parentheses. Significance at the 0.10 , 0.05 and 0.01 levels is indicated by ${ }^{*},{ }^{*}$ and ${ }^{* * *}$ respectively.

\subsection{Concluding Remarks}

Although the relation between corporate governance and performance has been studied extensively in the corporate finance literature, it has been investigated only partially for listed property companies. Most of the real estate literature investigates the effect of a combination of individual corporate governance elements on performance. This study fills the empirical gap by investigating the aggregate effect of corporate governance on performance, using a corporate governance index ( $C G O)$ that is provided by a leading governance-rating agency, Institutional Shareholder Services, and that covers a far greater number of REITs than other corporate governance indices.

REIT managers operate in a restricted setting. On the one hand this reduces the agency conflict by curbing managerial freedom, which might substitute the need for alternative corporate governance mechanisms and raise industry-wide governance standards. On the other hand, the legal restrictions might increase managerial entrenchment, thereby increasing the need for strong firm-level monitoring mechanisms. 
In line with the substitution hypothesis, we document for the REIT sample that our CGO index is neither related to REIT value, as measured by Tobin's 0 , nor to any of the three operating measures of performance, ROA, ROE, and FFO growth. These results contrast the consensus in the existing literature and the empirical evidence that we document for the complete CGO sample. Moreover, our findings are supported by evidence on two control samples and an additional robustness check. The first control sample exists of companies with relatively high corporate real estate ratios (CRERs), for which we find a relation between the CGQ index and performance, leading to the conclusion that the results we find for REITs are probably not driven by the assets they invest in. The second control sample is constructed by selecting all REITs in the G-Index, for which we do not find evidence of a relation between governance and performance either, implying that our results are not driven by the peculiarities of our dataset. However, when distinguishing high payout from low payout REITs, we find that governance does matter for the valuation of the latter. Comparing the results for the subsample of cash-rich REITs to the results for the sample of 5,000 regular $\mathrm{C}$-corporations, we document that a broader range of governance variables affects valuations for the second group. Our results corroborate with expectations that corporate governance has less impact on firm performance in strongly regulated business environments, as documented by Durnev and Kim (2005) and Klapper and Love (2004). We therefore explain the weak relation between corporate governance and performance in REITs as a 'REIT effect'.

This chapter has three caveats. First, we argue that corporate governance is static and that cross-sectional differences rather than time-series changes explain the effect of corporate governance on performance, but the short time span does not allow us to test how severe the endogeneity issue actually is. The causality of the governance - performance relationship has been topic of academic debate, but future research could take this issue into further consideration. Second, the relatively small sample of REITs does not allow us to dig very deep into the REIT sample. This would for example be preferable in section 4.4.3.3. However, this is inherent to research on listed real estate companies and cannot be solved appropriately at the moment. Countries all over the world converge towards standards for listed property companies comparable to U.S. REITs. This will likely broaden the scope of future corporate governance research in the real estate sector. Third, our index allows us to focus on all measures of corporate governance, but not ownership concentration. As institutional ownership is increasing in REITs and the role of shareholders is becoming more prominent, future research might incorporate this external governance mechanism in the analysis.

We conclude with one more consideration. In this chapter, we address the agency conflict from the point of view of an equityholder. However, this ignores the perspective of the bondholders. By optimizing the agency problem for equityholders, bondholders might well lose out, leading to a conflict of interest between equityholders and bondholders. In the strong institutional setting in which REITs operate, the degrees of managerial freedom are limited. This could imply that bondholders are not only better protected from the agency problem, but it could also reduce the conflict of interest with equity holders, leading to a lower cost of credit. Future research should therefore explore the relationship between credit spreads and the structure of corporate governance mechanisms in REITs. 


\section{Appendix 4.A}

Ratings Criteria ISS Corporate Governance Quotient

\begin{tabular}{|c|c|c|c|}
\hline \multicolumn{2}{|l|}{ Board } & \multicolumn{2}{|c|}{ State of Incorporation } \\
\hline 1 & Board Composition & $33-40$ & Takeover Provisions Applicable Under State \\
\hline 2 & Nominating Committee & & Law - Has Company Opted Out? \\
\hline 3 & Compensation Committee & & \\
\hline 4 & Governance Committee & \multicolumn{2}{|c|}{ Executive and Director Compensation } \\
\hline 5 & Board Structure & 41 & Cost of Option Plans \\
\hline 6 & Board Size & $42-43$ & Option Re-pricing \\
\hline 7 & Changes In Board Size & 44 & Shareholder Approval of Option Plans \\
\hline 8 & Cumulative Voting & 45 & Compensation Committee Interlocks \\
\hline 9 & Boards Served On - CEO & 46 & Director Compensation \\
\hline 10 & Boards Served On - Other Than CEO & 47 & Pension Plans For Non-Employee Directors \\
\hline 11 & Former CEO's & 48 & Option Expensing \\
\hline 12 & Chairman/CEOs Separation & 49 & Option Burn Rate \\
\hline 13 & Board Guidelines & 50 & Corporate Loans \\
\hline 14 & Response To Shareholder Proposals & & \\
\hline 15 & Board Attendance & \multicolumn{2}{|c|}{ Qualitative Factors } \\
\hline 16 & Board Vacancies & 51 & Retirement Age for Directors \\
\hline \multirow[t]{2}{*}{17} & Related Party Transactions & 52 & Board Performance Reviews \\
\hline & & 53 & Meetings of Outside Directors \\
\hline Audit & & 54 & CEO Succession Plan \\
\hline 18 & Audit Committee & 55 & Outside Advisors Available to Board \\
\hline 19 & Audit Fees & 56 & Directors resign upon job change \\
\hline 20 & Auditor Rotation & & \\
\hline \multirow[t]{2}{*}{21} & Auditor Ratification & \multicolumn{2}{|c|}{ Ownership } \\
\hline & & 57 & Director Ownership \\
\hline \multicolumn{2}{|c|}{ Charter/Bylaws } & 58 & Executive Stock Ownership Guidelines \\
\hline $22-27$ & Features of Poison Pills & 59 & Director Stock Ownership Guidelines \\
\hline $28-29$ & Vote Requirements & 60 & Officer and Director Stock Ownership \\
\hline 30 & Written Consent & & \\
\hline 31 & Special Meetings & \multicolumn{2}{|c|}{ Director Education } \\
\hline 32 & Board Amendments & 61 & Director Education \\
\hline 33 & Capital Structure & & \\
\hline
\end{tabular}

Notes: Appendix 4.A provides the ratings criteria used by Institutional Shareholder Services to construct the CGO index. To come to the final rating, some of the criteria are also looked at in combination, under the premise that corporate governance is enhanced when selected combinations of these criteria are adopted.

Source: Institutional Shareholder Services (2008) 







\section{Doing Well by Building Green?}

This chapter is based on Eichholtz, P.M.A.; Kok, N. and Quigley, J.M. "Doing Good by Doing Well: Green Office Buildings, "2008b. 


\section{Doing Well by Building Green?}

\subsection{Introduction}

It was recently announced ${ }^{27}$ that the Most Reverend Desmond Tutu, Archbishop Emeritus of Capetown, will be the keynote speaker at the annual conference and exposition on green building sponsored by the U.S. Green Building Council in November 2008. This announcement is the latest in the decade-long campaign by advocates of environmental conservation to draw attention to the imperative of "sustainability" in the construction and operation of buildings.

An appearance at the exposition by the Nobel Laureate, the recipient of the Gandhi Peace Prize, and the Albert Schweitzer Prize for Humanitarianism, will highlight the moral and humanitarian aspects of energy conservation in buildings.

An emerging consensus on the consequences of global warming, reinforced by academics such as Schelling (1992), together with the growing importance of "corporate social responsibility" as an intangible asset for competitive firms, has given the proponents of the green building movement increased credibility over time and has increased the salience of the issues they raise.

In fact, the behavior of the building sector is potentially quite important in matters of environmental sustainability. It is reported, for example, that buildings account for approximately forty percent of the consumption of raw materials and energy. In addition, 55 percent of the wood that is not used for fuel is consumed in construction. Overall, buildings and the associated materials produced for construction activity account for at least thirty percent of world greenhouse gas emissions (Royal Institute of Chartered Surveyors, 2005). And once a building is constructed, the energy consumption associated with it continues. The impact of energy costs directly affects the bottom-line of tenants and building owners. Energy represents thirty percent of operating expenses in a typical office building, which makes it the single largest and most manageable operating expense in the provision of office space.

These magnitudes suggest that real estate can play an important role in energy conservation in advanced societies. Awareness of this fact is growing. The increasing emphasis on "green rating" systems for buildings - initiated by both government and industry - gives testimony to this development. In general, these ratings assess the energy footprint of buildings, and they may provide owners and occupants with a solid yardstick for measuring the energy efficiency and sustainability of properties. However, the use of these ratings has so far

27 U.S. Green Building Council, News Release, January 7, 2008. 
been limited, and the global diffusion of rating systems is relatively slow. Moreover, both real estate developers and institutional investors are understandably uncertain about how far they should go in implementing environmental investments, since the business case for the development of sustainable buildings is based largely on anecdotal evidence. This contrasts with a growing body of evidence on the profitability of incorporating ecoefficiency measures in both strategic management and investment decision-making (Margolis and Walsh, 2003).

This chapter provides the first systematic analysis of the impact of environmentally-sustainable building practices upon economic outcomes measured in the marketplace. We concentrate upon commercial property and investigate the relationship between investments in energy efficiency in design and construction and the rents, effective rents, and selling prices commanded by these properties. We analyze a large sample of buildings, some of which have been certified as more energy efficient by independent and impartial rating services.

We assemble a national sample of U.S. office buildings which have been evaluated for energy efficiency by one or two leading agencies. For each building, we identify a control sample of nearby office buildings. For some 10,000 subject and control buildings, we relate contract rents, effective rents and selling prices to a set of objective hedonic characteristics of buildings, holding constant the locational characters of properties. We find that buildings with a "green rating" command rental rates that are roughly two percent higher per square foot than otherwise identical buildings - controlling for the quality and the specific location of office buildings. Premiums in expected rents, i.e., rents adjusted for building occupancy levels, are even higher - above six percent. Selling prices of green buildings are higher by about 16 percent. Beyond the average price or rental premium, our methodology also permits us to estimate the increment for each "green building" relative to the control buildings in its immediate geographic neighborhood.

We then use statistical methods to decompose this premium into several components. Our empirical results suggest that customers may be willing to pay a premium for the "socially responsible" attributes of green buildings. Alternatively, for owners it may be a successful marketing strategy to offer rated and labeled buildings in the marketplace. Our analysis provides a hint at evidence distinguishing the magnitude of these intangible marketing attributes from the energy efficiency attributes of the buildings.

Section 5.2 below provides a brief review of the emerging literature on corporate social responsibility and its relationship to environmentally sustainable buildings. We also discuss the sources of ratings for the environmental aspects of buildings. In Section 5.3 we describe the data used in our analysis, a unique body of micro data on the economic and hedonic characteristics of office buildings. Section 5.4 presents our methodology, and empirical results. Section 5.5 is a brief conclusion.

\subsection{Social Responsibility}

"Corporate social responsibility" (CSR, Waddock and Graves, 1997) has become a normative standard that describes firms' choices about inputs (e.g., the source of raw materials), internal processes (e.g., the treatment of employees), and outputs (e.g. community relations). Judgments about the social responsibility of private firms have become an investment criterion for some investors, and it is estimated that $\$ 2.7$ trillion is currently allocated to socially screened portfolios (SIF, 2007). However, the economic rationale for investing in companies 
or investment funds that rank high in corporate social performance is a matter of debate, and there is no consensus about the financial performance of these investments (Margolis and Walsh, 2003).

Companies with well-defined and aggressive CSR policies might be able to outperform others for several reasons: improved corporate reputation (Turban and Greening, 1997), less intrusion from activists and governmental organizations (Baron, 2001, Lyon and Maxwell, 2006), reduced threat of regulation (Maxwell, Lyon and Hackett, 2000), and improved profitability through lower input costs and higher employee productivity. The latter two represent the most tangible elements of corporate social responsibility. These factors have been defined as the so-called 'eco-efficiency,' or greenness of firms (WBCSD, 2002). Elements included in eco-efficiency are, for example, the external costs of natural resources, the costs of wastes created in and after the production process, and the costs associated with the labor environment (Vandermerwe and Oliff, 1990). Besides cost reduction, eco-efficiency may be incorporated in strategic decision-making to co-opt regulation and to differentiate products in final demand. Recent studies seem to suggest that operating performance and stock performance are enhanced by taking eco-efficiency measures into consideration (Derwall, Guenster, Bauer and Koedijk, 2005, Guenster, Derwall, Bauer and Koedijk, 2005).

In the real estate sector, issues of eco-efficiency are confounded with straightforward capital budgeting decisions involving choices between the levels and types of initial investment and consequent operating inputs to maximize investor returns. In this context, the investment in eco-efficient or green buildings could lead to economic benefits in at least four ways.

First, investments at the time of construction or renovation may: save current resources expended on energy, water and waste disposal; decrease other operating costs; insure against future energy price increases; and simultaneously decrease greenhouse gas emissions. The financial benefits of energy savings and waste reduction are relatively easy to measure, but existing empirical studies focus on environmental performance rather than financial performance. For example, Khanna and Damon (1999) study how reductions in releases of chemicals influences financial performance in the chemical industry; they find that firms that reduce the release of toxic chemicals suffer losses in the short run, but gain in the long run. For real estate, the evidence on energy savings in green buildings is typically based upon engineering studies of energy usage. There seems to be a consensus that a variety of capital expenditures improving energy efficiency in property are cost-effective at reasonable interest rates, given current and projected energy costs.

Second, an improved indoor environmental quality in green buildings might result in higher employee productivity. But while energy and waste savings can be measured fairly precisely, the relation between employee productivity and building design or operation is far more complicated. The financial impact of healthier and more comfortable green buildings is hard to assess, in part because the cost of poor indoor environmental quality (for example, lower productivity and higher absenteeism) may simply be hidden. However, there is popular discussion of the putative health and productivity costs that are imposed by poor indoor environmental quality in commercial buildings ${ }^{28}$ Consequently, tenants may be willing to pay a higher rent for buildings in which indoor environmental quality is better.

28 See www.epa.gov/iaq for more background information. 
Third, locating corporate activities in a green building can positively affect the corporate image of tenants. Leasing space in a green building may send a concrete signal of social awareness, and of the superior social responsibility of tenants. This may be important for some tenants, and may be a determinant of corporate reputation (Fombrun and Shanley, 1990). Favorable reputations may enable firms to charge premium prices (Klein and Leffler, 1981), to attract a better workforce (Turban and Greening, 1997), and to attract investors (Milgrom and Roberts, 1986). As a result, tenants may be willing to pay higher rents for green buildings.

Fourth, sustainable buildings might have longer economic lives, following less depreciation, and lower volatility in market value, following less environmental and marketability risk. This leads to reduced risk premiums and higher valuations of the properties. Orlitzky and Benjamin (2001) address the relation between corporate social performance and risk, and argue that the better a firm's social reputation, the lower its total market risk. If this relationship holds for the real estate sector, building green may result in a lower cost of capital and higher building valuation. So even if green buildings did not command higher spot rents, they could still be valued higher.

Economists are quick to point out that many of the advantages of eco-efficiency could be obtained if energy inputs were appropriately priced (to reflect their social and environmental costs). Appropriate investments in energy efficiency would minimize life cycle costs discounted at market rates, maximize developer returns, and correctly economize on energy costs (Quigley, 1984, 1985, 1991, Quigley and Rubinfield, 1989). But to the extent that productivity, corporate image, and intangible or hard-to-measure returns are important, simple adjustments of input prices are just that -- too simple.

If the economic benefits of green building for commercial property are indeed reflected in tenants' willingness to pay a premium on net rent for green space or in lower risk premiums for green buildings, this would enable investors to offset the higher initial investment required for sustainable buildings, or even to command higher risk-adjusted returns. However, for real estate investors, hard evidence on the financial performance of green buildings is limited and consists mainly of industry-initiated case studies. Prominent among these is an influential report for California's Sustainable Building Task Force (2003) on the costs and financial benefits of green buildings. For a sample of 33 buildings with a green rating in California, it was estimated that the financial benefits of green design are ten times as large as the incremental outlay to finance the green investment.

However, the sources of the financial benefits identified in this study are diverse, hard to quantify, and ultimately not credible. To persuade real estate developers and investors in the global marketplace of the benefits of "ecoinvestment," the payoff of investment in green buildings needs to be identified in that same marketplace.

\subsection{Data on Commercial Buildings}

In the U.S., there are two major programs that encourage the development of energy-efficient and sustainable buildings through systems of ratings to designate and publicize exemplary buildings. The Energy Star program is jointly sponsored by two federal agencies, the U.S. Environmental Protection Agency and the U.S. Department of Energy. Energy Star began in 1992 as a voluntary labeling program designed to identify and promote energy-efficient products in order to reduce greenhouse gas emissions. Energy Star labels were first applied to computers and computer equipment and were later extended to office equipment, to residential heating 
and cooling equipment, and to major appliances. The Energy Star label was extended to new homes in 1993 and has been marketed as an efficient way for consumers to identify builders as well as buildings constructed using energy-efficient methods. The Energy Star label is marketed as an indication of lower ownership costs, better energy performance, and higher home resale values. The label is also marketed as an indication of better environmental protection, and the Energy Star website for new homes stresses that "your home can be a greater source of pollution than your car." The Energy Star label was extended to non-residential buildings in 1995.

Non-residential buildings can receive an Energy Star certification if the site energy use, the energy intensity, and the greenhouse gas emissions of the building, as certified by a professional engineer, achieve certain specified benchmark levels. The Energy Star label is marketed as a commitment to conservation and environmental stewardship. But it is also touted as a vehicle for reducing building costs and for demonstrating superior management skill. Indeed the Energy Star website draws attention to the relationship between energy conservation in buildings and other indicia of good "corporate governance." As of December 2007, 4,113 buildings in the U.S. had been awarded the Energy Star designation, including 1,514 office buildings.

The U.S. Green Building Council (USGBC), a private non-profit organization, has developed the LEED ("Leadership in Energy and Environmental Design"' green building rating system to encourage the "adoption of sustainable green building and development practices." Since adoption in 1999, separate standards have been applied to new buildings and to existing structures. The requirements for certification of LEED buildings are substantially more complex than those for the award of an Energy Star rating, and additional points in the certification process are awarded for such factors as "site selection," "brownfield redevelopment," and the availability of "bicycle storage and changing rooms," as well as energy performance. It is claimed that LEED-certified buildings have lower operating costs and increased asset values and provide healthier and safer environments for occupants. It is also nated that the award of a LEED designation "demonstrate[s] an owner's commitment to environmental stewardship and social responsibility." As of December 2007, there were 1,228 buildings certified by the LEED Program of the USGBC.

Energy Star-rated buildings and LEED-rated buildings are identified by street address on the websites of Energy Star and the USGBC respectively. We matched the addresses of the rated buildings in these two programs to the office buildings identified in the archives maintained by the CoStar Group. The CoStar service and the data files maintained by CoStar are advertised as "the most complete source of commercial real estate information in the U.S." The CoStar Group maintains an extensive micro database of approximately 332,000 U.S. commercial buildings, their locations, and hedonic characteristics, as well as the current tenancy and rental terms for the buildings. A separate file is maintained of the recent sales of commercial buildings. Our match yielded 1,360 green office buildings which could be identified in CoStar, of which 286 were certified by LEED, 1,045 were certified by Energy Star, and 29 were certified by both LEED and Energy Star ${ }^{29}$

Figure 5.1 provides a geographic summary of our match between the Energy Star-certified commercial office buildings, the LEED-certified buildings, and the universe of commercial buildings identified in CoStar. The figure reports the number of certified commercial office buildings in each state, as well as an estimate of the fraction

29 In the December 2007 version of the CoStar database, green-rated buildings are separately identified. However, in matching the EnergyStar and LEED-certified buildings by street address, we discovered that about a quarter of the certified buildings were not recorded in the CoStar data. 
of office space in each state which has been rated for environmental sustainability. ${ }^{30}$ About four percent of U.S. office building space is green-labeled. As the map indicates, in some states - notably Texas, Washington, and Minnesota - more than five percent of office buildings are rated. The incidence of green office space is almost nine percent in California - 122 million square feet of office space are labeled. In a large number of states, however, only a small fraction of office space is certified by Energy Star or the USGBC. States with extreme temperatures are apparently more likely to have rated office buildings.

\section{Figure 5.1}

Distribution of Green Office Buildings by State (percent of the stock of office space)

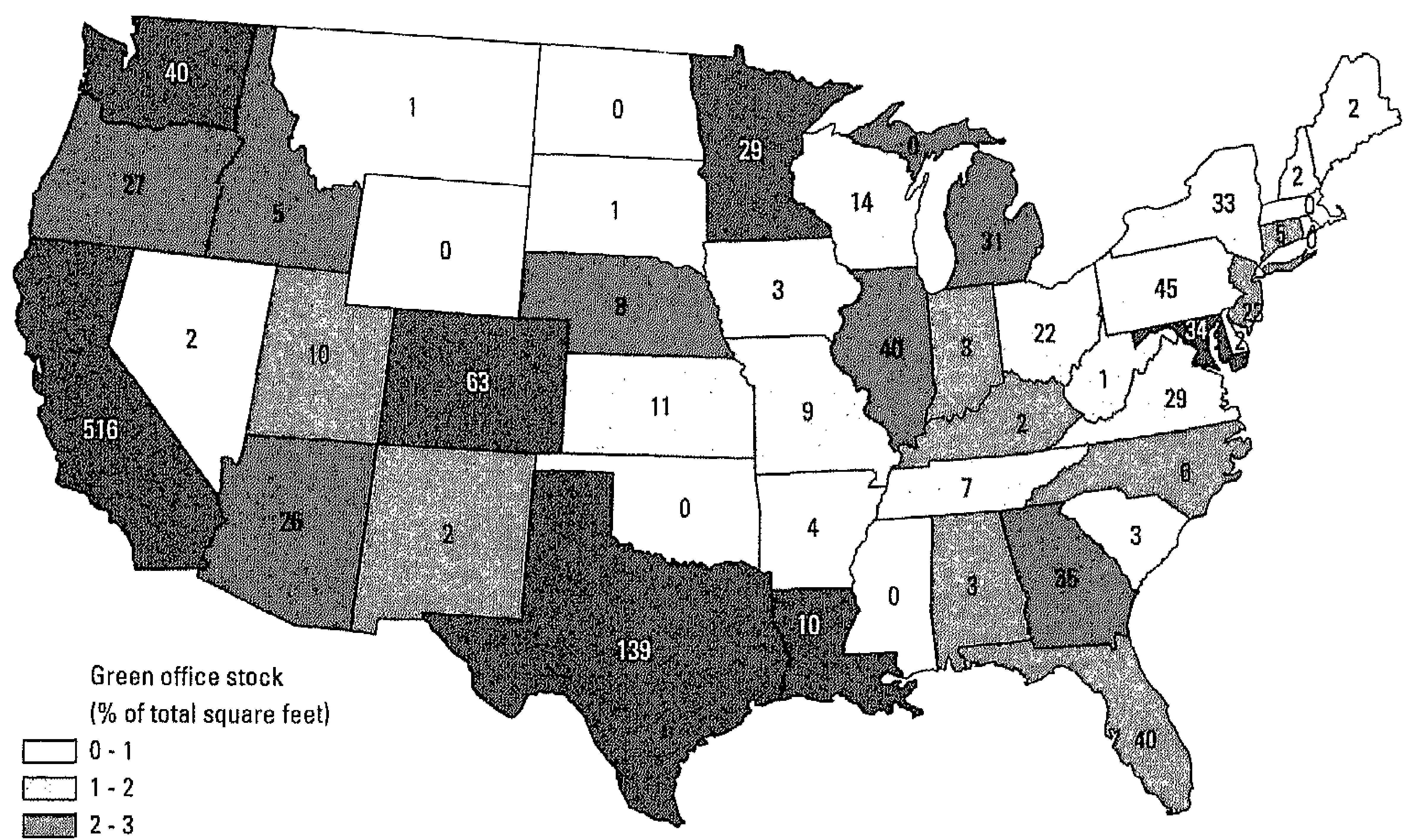

Source: Costar and authors' calculations

30 This probably overstates the fraction of green office space in the U.S. inventory, since CoStar's coverage of smaller and older office buildings is less complete. 
Chapter 5. Doing Well by Building Green?

\subsubsection{The Analysis Sample}

Of the 1,360 rated buildings identified in the CoStar database, current information about building characteristics and monthly rents were available for 694 buildings. 199 of these buildings were sold between 2004 and $2007 .{ }^{31}$ To investigate the effect of energy efficiency on the rents and values of commercial buildings, we matched each of the rated buildings in this sample to nearby commercial buildings in the same market. Based upon the latitude and longitude of each rated building, we use GIS techniques to identify all other office buildings in the CoStar database within a radius of one quarter mile. In this way, we create 893 (i.e., 694 plus 199) clusters of nearby office buildings. Each small cluster -- 0.2 square miles -- contains one rated and at least one non-rated nearby building. On average, each cluster contains about 12 buildings. There are 8,182 commercial office buildings in the sample of green buildings and control buildings with rental data and 1,816 buildings in the sample of buildings which have been sold.

Table 5.1 compares the average characteristics of the green buildings with the nearby buildings selected for comparison. For the rental sample, the green buildings are substantially larger, on average than the control buildings. They have slightly higher occupancy rates, and the cross-sectional variability in occupancy is lower for green buildings than for the control buildings. They are also more likely to have a net rent contract, in which the tenants pay directly for utilities. On average, the green buildings are slightly taller, by about two stories. The green buildings are much newer, averaging about 24 years in age while the control sample of buildings is about 44 years old, on average. Because they are older, the control buildings are much more likely to have been renovated than the green buildings.

31 We choose this interval, in part, because the formula for rating office buildings was unchanged throughout the period. 
Table 5.1

Comparison of Green-Rated Buildings and Nearby Control Buildings

Rental Sample and Sales Sample

(standard deviations in parentheses)

\begin{tabular}{|c|c|c|c|c|}
\hline \multirow{4}{*}{$\overline{\text { Sample Size }}$} & \multicolumn{2}{|c|}{ Rental Data } & \multicolumn{2}{|c|}{ Sales Data } \\
\hline & Green & Control & Green & Control \\
\hline & Buildings & Sample & Sample & Sample \\
\hline & 694 & 7,488 & 199 & 1,617 \\
\hline Asking Rent & 29.80 & 28.16 & & \\
\hline (dollars/sq.ft.) & (13.05) & (15.77) & & \\
\hline Effective Rent* & 26.74 & 23.57 & & \\
\hline (dollars/sq. ft.) & $(13.09)$ & $(16.69)$ & & \\
\hline Sales Price & & & 289.22 & 248.89 \\
\hline (dollars/sq. ft.) & & & $(165.70)$ & $(255.49)$ \\
\hline Net Rent Contract** & 5.76 & 3.15 & & \\
\hline (percent) & (23.32) & $(17.47)$ & & \\
\hline Size & 324.08 & 218.69 & 358.33 & 159.12 \\
\hline (thousands sq. ft.) & (288.92) & (293.69) & $(287.86)$ & $(257.50)$ \\
\hline Occupancy Rate & 88.99 & 81.35 & & \\
\hline (percent) & $(13.19)$ & (22.74) & & \\
\hline Stories & 15.31 & 13.07 & 16.47 & 10.35 \\
\hline (number) & $(13.26)$ & $(12.10)$ & $(12.76)$ & $(10.50)$ \\
\hline \multicolumn{5}{|l|}{ Stories (percent) } \\
\hline \multirow{2}{*}{ Low $(<10)$} & 14.27 & 21.26 & 44.12 & 63.33 \\
\hline & $(35.00)$ & (40.92) & $(49.77)$ & $(48.21)$ \\
\hline \multirow{2}{*}{ Medium (10-20) } & 26.66 & 25.25 & 23.04 & 21.34 \\
\hline & (44.25) & $(43.45)$ & (42.21) & $(40.98)$ \\
\hline \multirow{2}{*}{ High $(>20)$} & 46.26 & 53.49 & 32.84 & 15.34 \\
\hline & 49.90 & (49.88) & (47.08) & $(36.05)$ \\
\hline \multicolumn{5}{|l|}{ Age } \\
\hline \multirow[t]{2}{*}{ (years) } & 23.75 & 49.44 & 24.64 & 60.38 \\
\hline & $(15.75)$ & $(32.50)$ & $(16.40)$ & $(35.61)$ \\
\hline \multicolumn{5}{|l|}{ Age (percent) } \\
\hline \multirow{2}{*}{ Less than 10 years } & 14.27 & 4.87 & 16.18 & 4.14 \\
\hline & $(35.00)$ & $(21.53)$ & $\langle 36.91\rangle$ & $(19.94)$ \\
\hline \multirow{2}{*}{10 to 20 years } & 24.06 & 9.40 & 21.08 & 6.43 \\
\hline & (42.78) & (29.18) & $(40.89)$ & $(24.54)$ \\
\hline \multirow{2}{*}{21 to 30 years } & 43.37 & 25.13 & 42.16 & 20.22 \\
\hline & (49.59) & (43.38) & $(49.50)$ & $(40.18)$ \\
\hline \multirow{2}{*}{31 to 40 years } & 11.10 & 13.25 & 11.76 & 8.53 \\
\hline & $(31.43)$ & (33.90) & $(32.30)$ & (27.94) \\
\hline \multirow{2}{*}{ Over 40 years } & 7.20 & 47.34 & 8.82 & 60.67 \\
\hline & $(25.88)$ & (49.93) & $(28.43)$ & $(48.86)$ \\
\hline
\end{tabular}


Table 5.1

Comparison of Green-Rated Buildings and Nearby Control Buildings (standard deviations in parentheses)

Continued

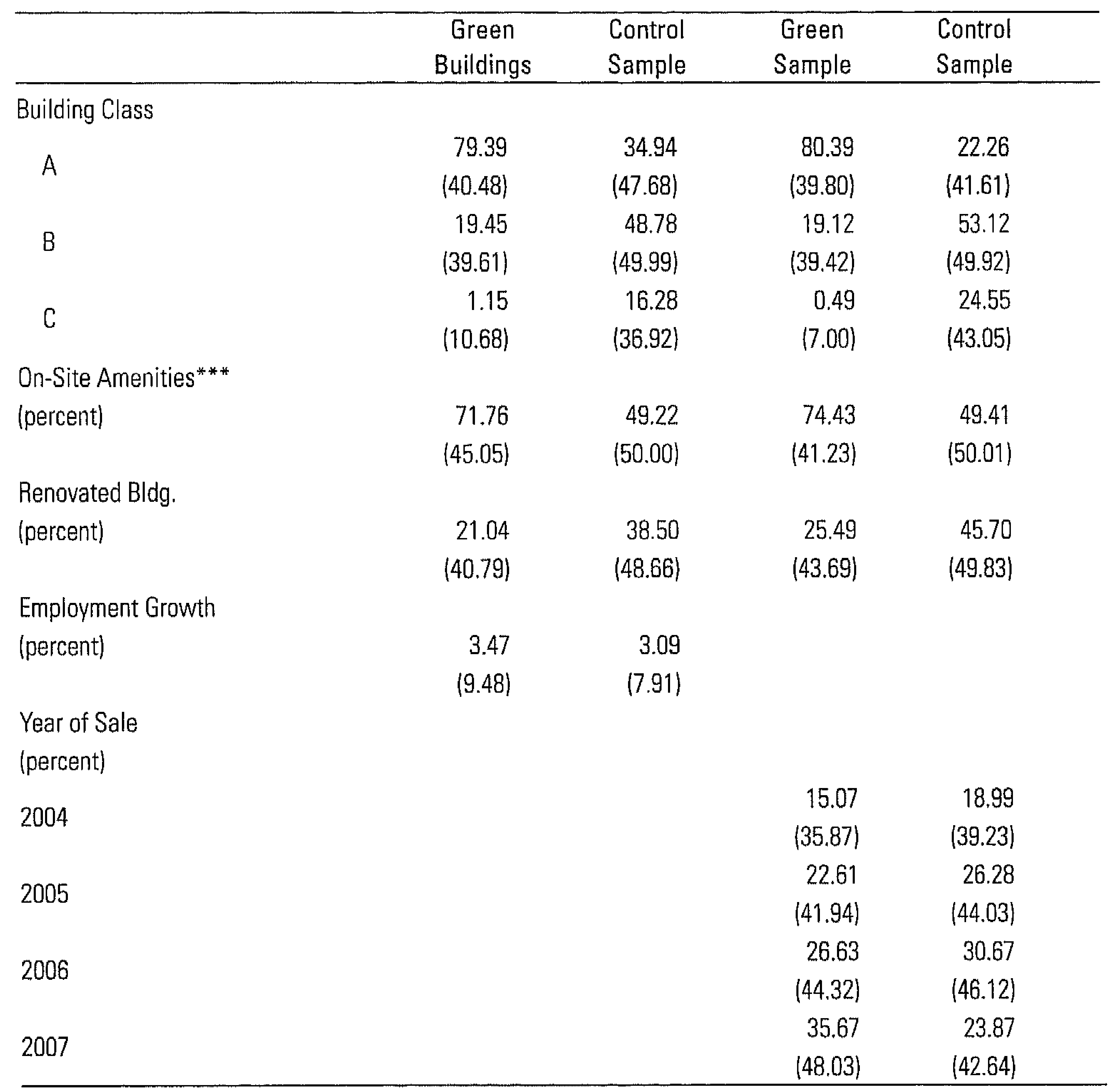

Notes: The control sample consists of all commercial office buildings within a 0.25 mile radius of each rated building.

${ }^{*}$ Effective Rent equals the Asking Rent multiplied by the Occupancy Rate

**Net Rent Contracts require tenants to pay separately for utilities.

*** One or more of the following amenities are available on-site: banking, convenience store, dry cleaner, exercise facilities, food court, food service, mail room, restaurant, retail shops, vending areas, fitness center. 
The overall quality of the green buildings is substantially higher. 79 percent are rated as "class A," while only 35 percent of the control buildings have that rating. Only about one percent of the green buildings are rated as class $C$, while over 16 percent of the control buildings have this rating. A larger fraction of green buildings have on-site amenities such as retail shops, mail rooms, and exercise facilities.

The sample of sold buildings exhibits the same qualitative features, but the differences between the green and the non-green buildings are larger. Certified green buildings are twice as large. They are of much higher quality, and they are much newer. Eighty percent of the green buildings are considered class A buildings, and only 22 percent of the non-green buildings have this rating. Thirty-six percent of the green buildings are less than twenty years old; only eleven percent of the non-green buildings are less than twenty years old.

Figures 5.2 and 5.3 further illustrate the difference in the distributions of characteristics between the green buildings and the control sample. As reported in panel $A$ of each figure, the age distribution of the control sample is bimodal, with a substantial fraction above 50 years of age. Panel $B$ illustrates the differences in effective rents and selling prices between the green samples and the control samples, while panel $C$ illustrates the differences in the size distributions between the green and non-green buildings in the two samples.

Figure 5.2

Age, Effective Rent and Size

Rental Sample: Green Buildings and Control Buildings

\section{A. Age}

Control Sample

Green Sample
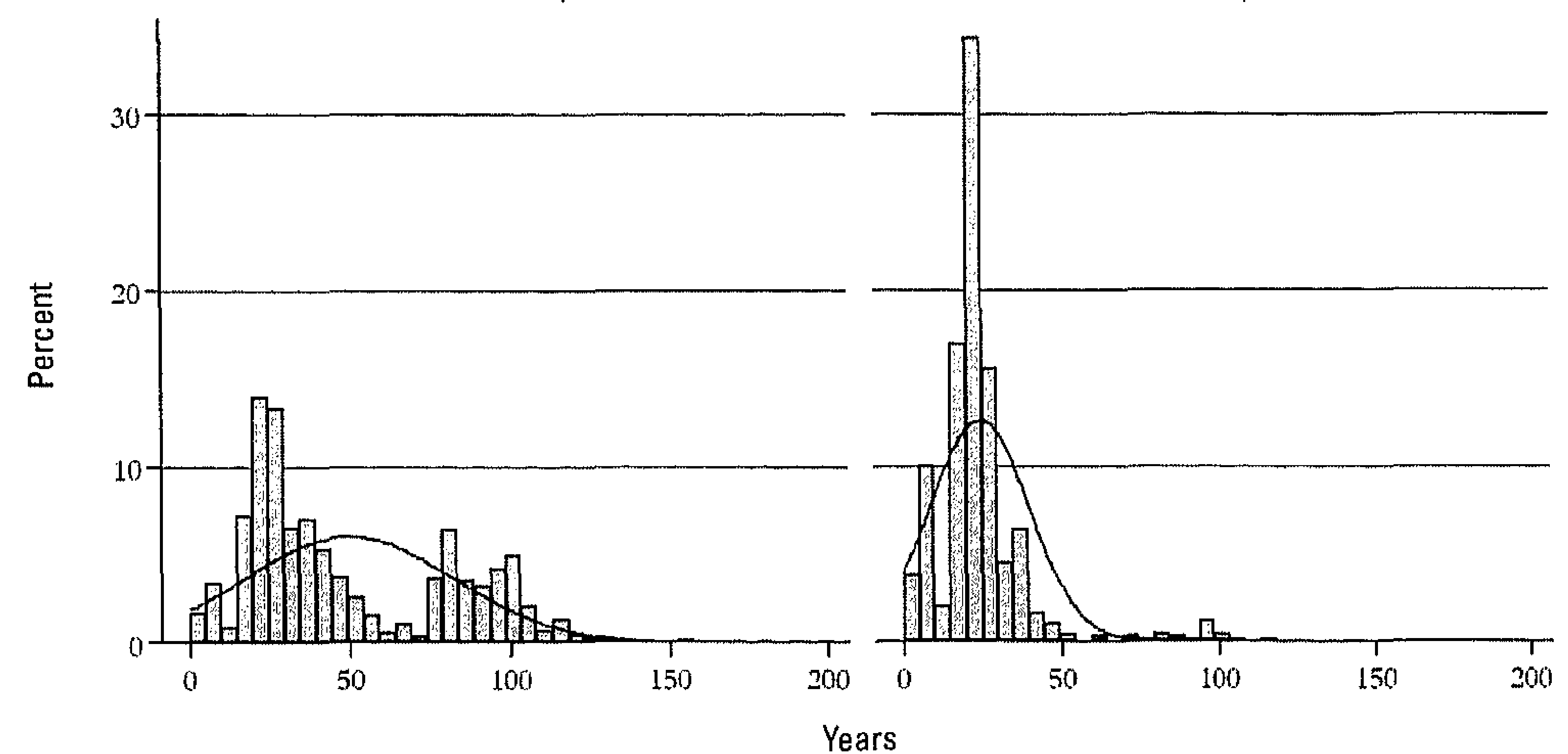


\section{B. Effective Rent}
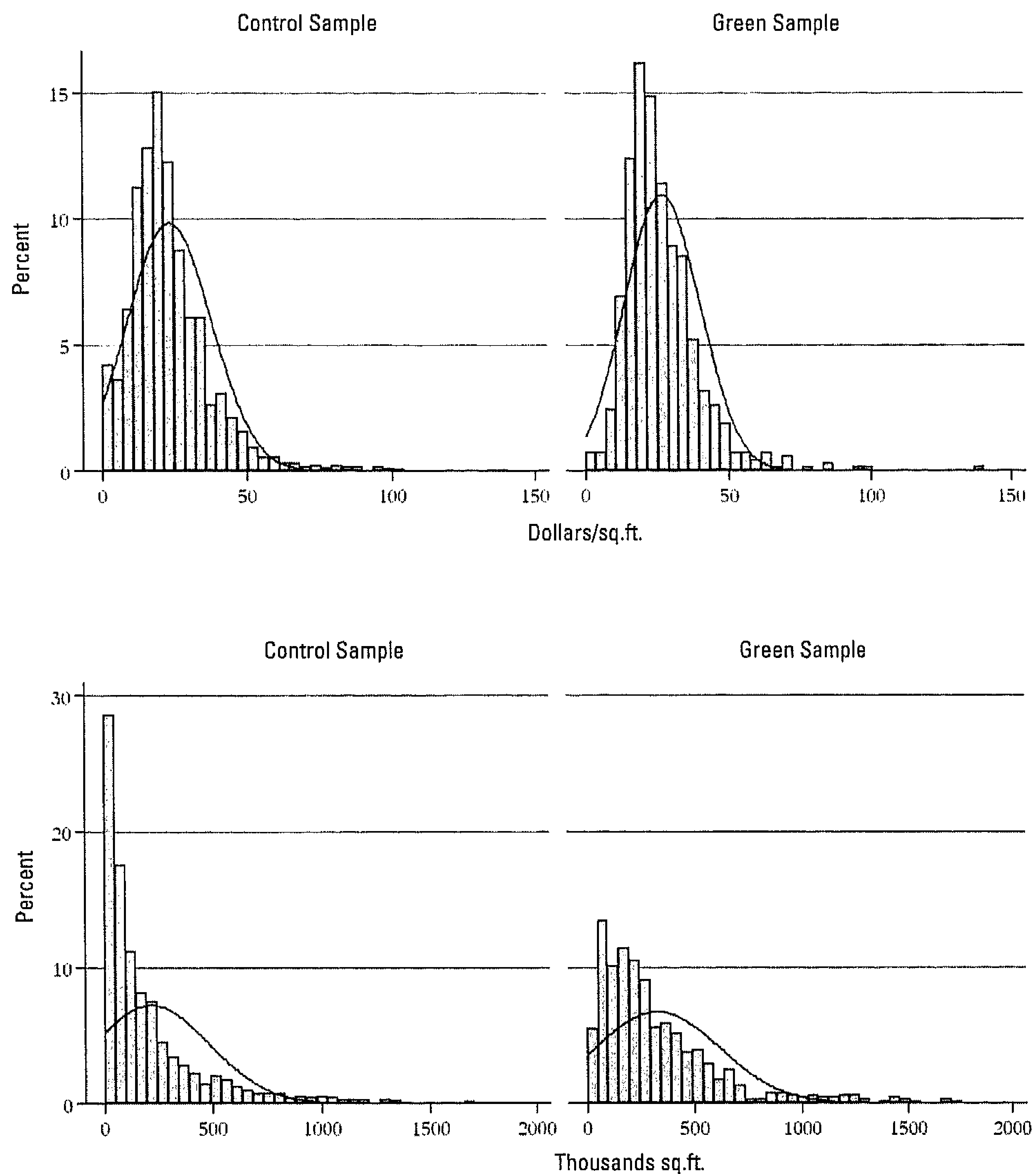
Figure 5.3

Age, Sales Price and Size

Sales Sample: Green Buildings and Control Buildings

A. Age

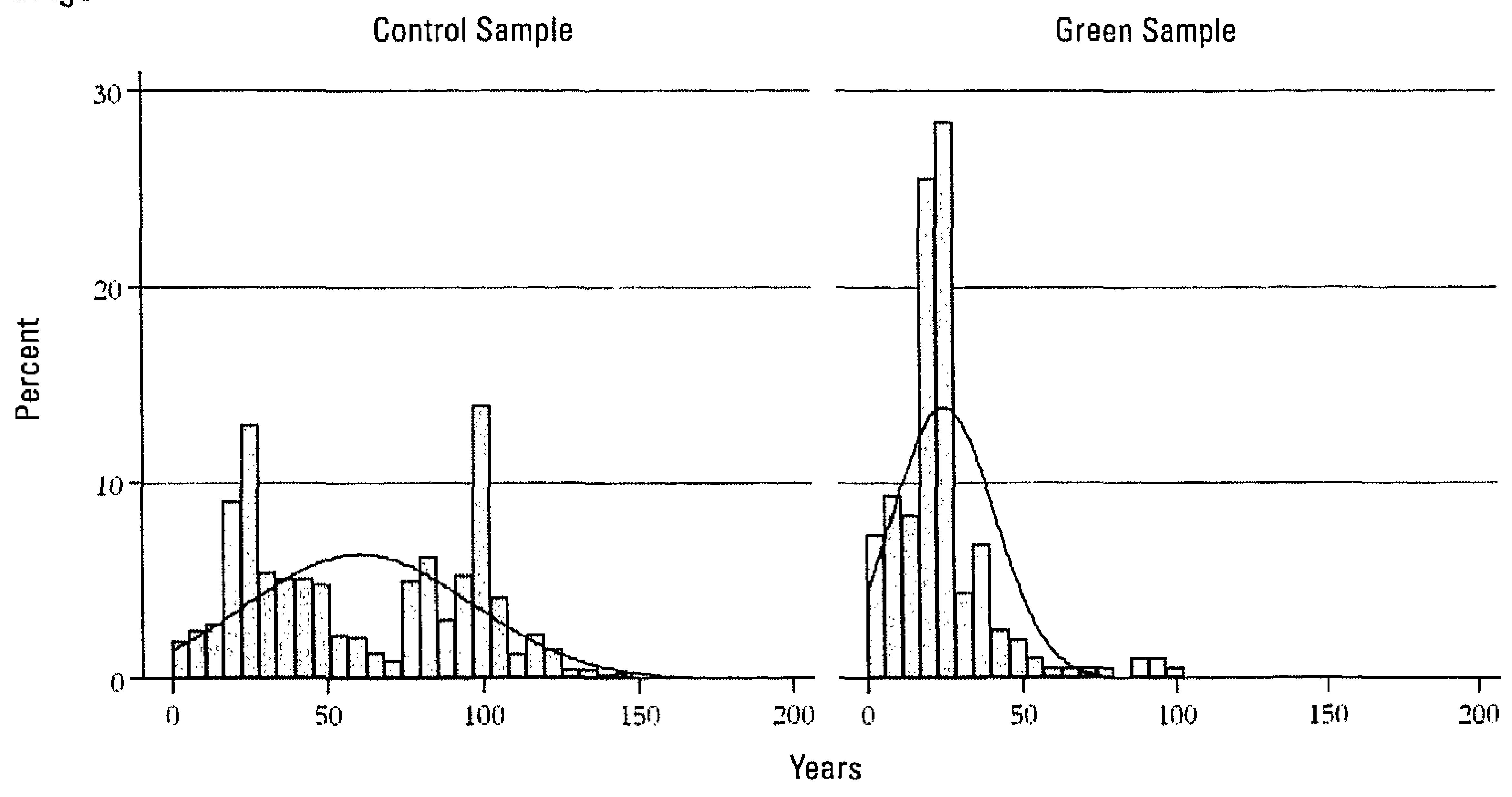

B. Sales Price

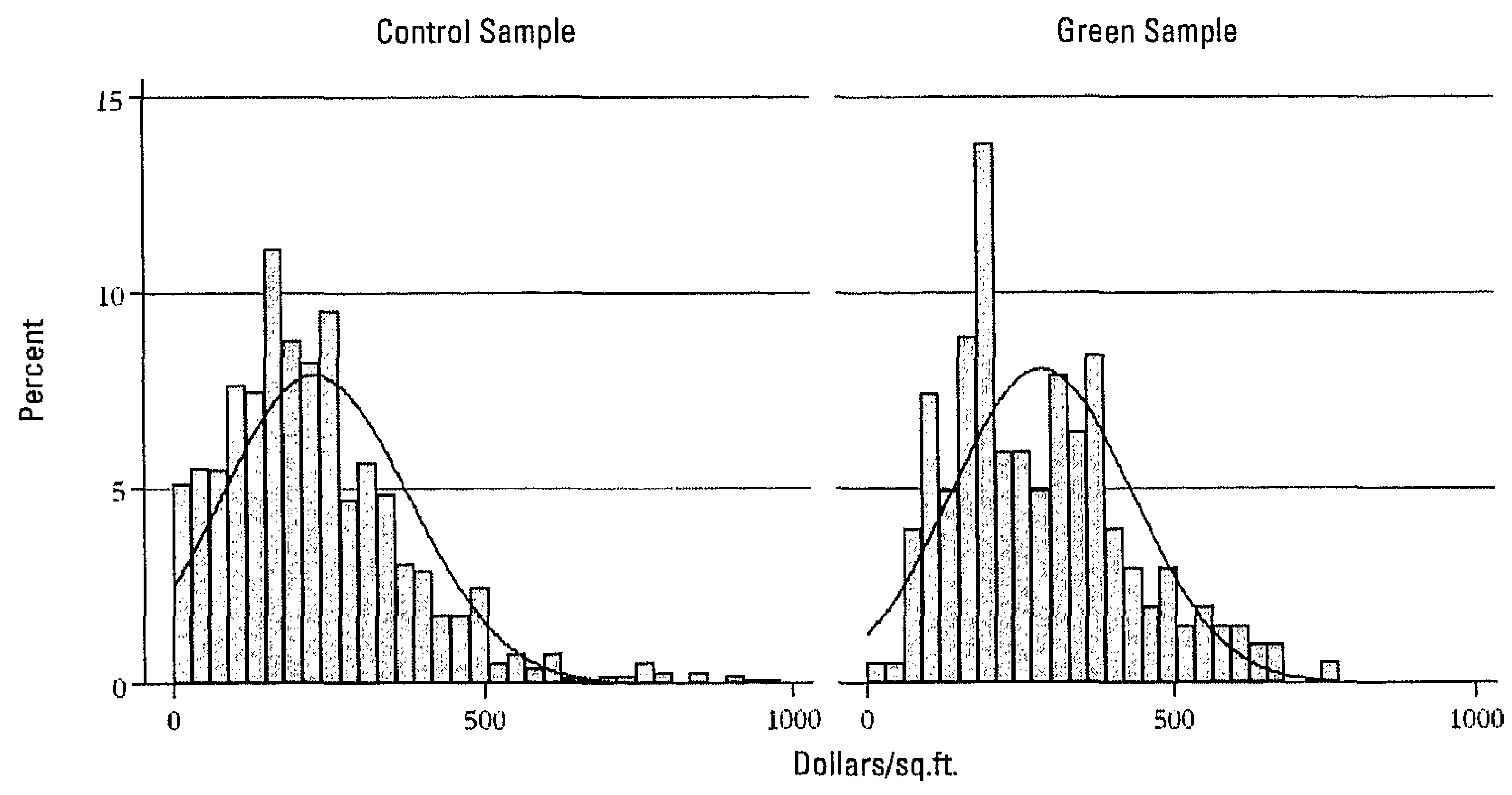




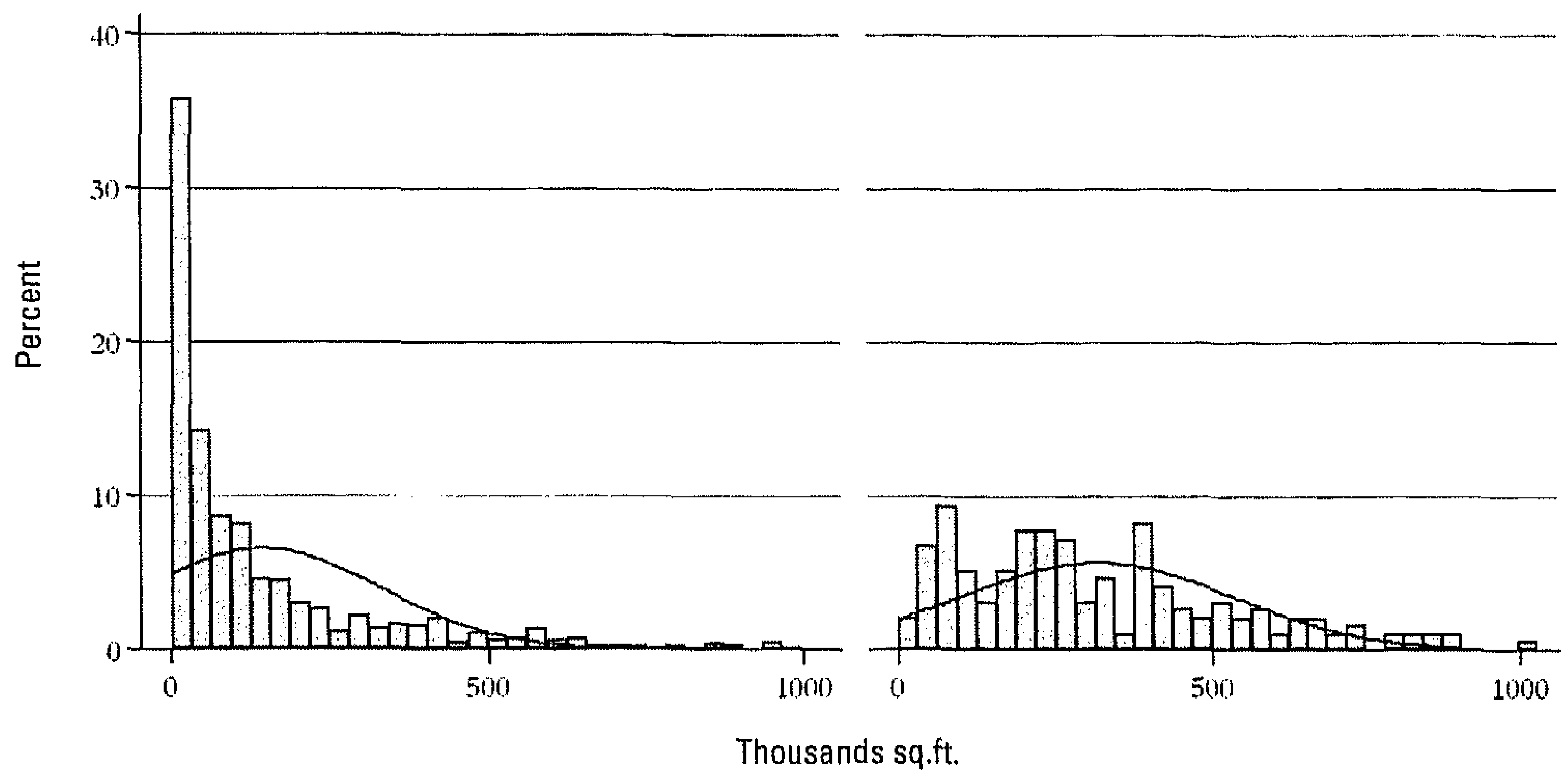

\subsection{Empirical Analysis and Results}

\subsubsection{Methods}

To investigate how energy efficiency influences rent and value in commercial office buildings, we use the standard valuation framework for commercial real estate. Our analysis of energy rated office buildings, combined with a control sample consisting of one-or-more nearby nonrated office buildings, is conducted in two steps. First we estimate a semi-log equation relating office rentals (or selling prices) per square foot to the hedonic characteristics of the buildings (e.g., age, amenities provided, parking, etc.) and the location of each building:

$\log R_{i n}=\alpha+\beta_{i} X_{i}+\sum_{n=1}^{N} \gamma_{n} c_{n}+\delta g_{i}+\varepsilon_{i n}$

$\log R_{i n}=\alpha+B_{i} X_{i}+\sum_{n=1}^{N}{\gamma_{n}}_{n} c_{n}+\sum_{n=1}^{N} \delta_{n}\left[c_{n} \cdot g_{i}\right]+\varepsilon_{m}$

In the formulation represented by equation (5.1a), the dependent variable is the logarithm of the rent per square foot $R_{\text {in }}$ in commercial office building $i$ in cluster $n$. In other results presented, the dependent variable is the logarithm of effective rent per square foot ${ }^{32}$ or the selling price per square foot. $X_{i}$ is a vector of the hedonic characteristics of building $i . c_{n}$ is a dummy variable with a value of 1 if building $i$ is located in cluster $n$ and zero otherwise. $g_{i}$ is a dummy variable with a value of 1 if building $i$ is rated by Energy Star or USGBC and zero otherwise. $\alpha_{1} \beta_{i^{\prime}} \gamma_{n}$ and $\delta$ are estimated coefficients and $\varepsilon_{\text {in }}$ is an error term. For the sample of rental properties in expression (5.1a) there are 694 location coefficients which may affect office rents, one for each of the $N$ distinct

32 That is, the rent per square foot multiplied by the occupancy rate. 
0.2 -square-mile clusters. ${ }^{33}$ The increment to rent associated with a rated building is $\exp [\delta]$. For the sample of sold buildings, there are 199 location coefficients, one for each cluster, as well as dummy variables for the year of sale.

In equation (5.1b), the locational measure is further generalized. In this formulation, the effect on commercial rents or selling prices of a green rating may vary separately for green buildings in each of the 694 clusters in the rental sample and for green buildings in each of the 199 clusters in the sample of sold buildings.

Our formulation generalizes the treatment of spatial variation in the real estate asset pricing literature. In this literature, spatial variation is commonly analyzed in one of three ways: first, by including location dummies for submarkets (Glasscock, Johanian and Sirmans, 1990, Wheaton and Torto, 1994); second, by studying a specific MSA or city and thereby isolating the influence of spatial variation (Gunnelin and Söderberg, 2003, Rosen, 1984, Webb and Fisher, 1996); or else by using Geographic Information System (GIS) methods to specify the distance of a property to specific locations, for example the central business district (CBD), airport, highway or railway station (Bollinger, Ihlanfeldt and Bowes, 1998, Öven and Pekdemir, 2006, Sivitanidou, 1995, Sivitanidou, 1996). Our analysis generalizes these methods by treating each of the small geographic clusters as distinct.

In the second part of the analysis, we seek to distinguish the effects of the energy-saving component of the rating from the intangible effects of the label itself. These latter effects may arise from the reputational or marketing benefits of the labeled building or from other unmeasured aspects of quality in rated buildings. These models take the form:

$\hat{\delta}_{n}=\alpha+\beta_{j} Z_{j n}+\gamma_{j i} \sum_{i=1}^{\prime} \sum_{j=1}^{J} X_{i} Z_{j n}+\varepsilon_{n}$

The dependent variable $\hat{\delta}_{n}$, is the estimate of the increment to rent commanded by the green building in cluster $n$, relative to the control buildings in that cluster, holding constant the hedonic characteristics of the buildings. $Z_{n}$ is a vector of the thermal and climatic attributes $j$ of cluster $n . X Z_{i n}$ is the interaction of the climatic attributes of cluster $n$ and selected hedonic attributes of building $i$.

As before, the Greek letters $\alpha_{i} \beta_{j}$ and $\gamma_{j i}$ denote estimated coefficients, and $\varepsilon_{n}$ is an error term. Note that the dependent variable is itself a regression estimate obtained from Equation (5.1b). Thus Equation (5.2) is appropriately estimated by generalized least-squares, incorporating the variance-covariance matrix of estimated parameters from equation (5.1b). See Hanushek (1974).

\subsubsection{Results}

Table 5.2 presents the basic results for the rental sample, relating the logarithm of rent per square foot in commercial office buildings to a set of hedonic and other characteristics of the buildings. Results are presented for ordinary least squares regression models corrected for heteroskedasticity (White, 1980). Column (1) reports a basic model relating rent to building quality, measured by class designation, size, and occupancy rate. The regression, based upon 8,182 observations on buildings (694 rated buildings and 7,488 control buildings each located within 1,300 feet of a rated building) explains some 71 percent of log rent. When rents are quoted

33 In this way, the equation recognizes the old adage about the three most important determinants of property valuation: "location, location location." 
gross, they are about four percent higher than when they are quoted net of utilities. Higher quality buildings, as measured by building class, command a substantial premium. Rent in a class A building is about twenty-four percent higher than in a class $\mathrm{C}$ building, and about fourteen percent higher than in a class $\mathrm{B}$ building. Rent is significantly higher in larger buildings, as measured by square footage, but the magnitude is quite small, about one percent for an additional 100,000 square feet. The 694 dummy variables for location are highly significant with an F-ratio of 22.96. Importantly, holding other factors constant, the estimated rent premium for a green building is about 2.6 percent.

In column (2), the green certification is distinguished by its Energy Star or its LEED rating. The results suggest that the LEED rating has no effect upon commercial rents, but the Energy Star rating is associated with rents higher by 2.8 percent. In column 3 , a set of variables measuring building age in four categories is added to the model. The coefficients of the other variables are quite stable. The results indicate that there is a substantial premium associated with newer buildings. Ceteris paribus, rents in a commercial office building less than ten years old are twelve percent higher than those in a building more than forty years old.

Column (4) adjusts for differences in the number of stories and the presence of on-site amenities. There is evidence that rents in very tall buildings, greater than twenty stories, are slightly lower. On-site amenities are associated with higher office rents. Importantly, when the specification of the hedonic variables is changed in various ways, the magnitude and the statistical significance of the green rating is unchanged. Ceteris paribus, the rent in a green building is significantly higher by 1.9 to 2.6 percent than in an unrated building.

Column (5) presents the results from estimation of equation (5.1b). In this formulation, the specification includes 1,388 dummy variables (not reported in the table) - one for each of the 694 clusters, and one for the specific green building identified in each cluster. When the model is expanded in this way, the coefficients of the other variables are unchanged. Of course, in this more general specification, the rent premium for a green building varies in magnitude for each separate cluster. 
Table 5.2

Regression Results

Commercial Office Rents and Green Ratings

(dependent variable: logarithm of rent per square foot)

\begin{tabular}{|c|c|c|c|c|c|}
\hline & (1) & (2) & (3) & (4) & (5) \\
\hline \multirow[t]{2}{*}{ Green Rating $(1=$ yes $)$} & 0.026 & & 0.023 & & 0.019 \\
\hline & {$[0.011]^{* *}$} & & {$[0.011]^{* *}$} & & {$[0.011]^{*}$} \\
\hline \multirow[t]{2}{*}{ Energy Star $(1=$ yes $)$} & & 0.028 & & & \\
\hline & & {$[0.012]^{* *}$} & & & \\
\hline \multirow[t]{2}{*}{$\operatorname{LEED}(1=$ yes $)$} & & 0.003 & & & \\
\hline & & {$[0.037]$} & & & \\
\hline \multirow[t]{2}{*}{ Building Size (millions of sq. ft.) } & 0.112 & 0.112 & 0.100 & 0.109 & 0.109 \\
\hline & {$[0.013]^{* * *}$} & {$[0.013]^{* * *}$} & {$[0.014]^{* * *}$} & {$[0.015]^{* * *}$} & {$[0.016]^{* * *}$} \\
\hline \multirow[t]{2}{*}{ Fraction Occupied } & 0.017 & 0.017 & 0.017 & 0.007 & 0.002 \\
\hline & {$[0.015]$} & {$[0.015]$} & {$[0.015]$} & {$[0.015]$} & {$[0.015]$} \\
\hline \multicolumn{6}{|l|}{ Building Class: } \\
\hline \multirow{2}{*}{ Class $A(1=$ yes $)$} & 0.237 & 0.236 & 0.197 & 0.177 & 0.177 \\
\hline & {$[0.011]^{* * *}$} & {$[0.011]^{* * *}$} & {$[0.013]^{* * *}$} & {$[0.013]^{* * *}$} & {$[0.014]^{* * *}$} \\
\hline \multirow[t]{2}{*}{ Class $B(1=$ yes $)$} & 0.103 & 0.103 & 0.093 & 0.084 & 0.082 \\
\hline & {$[0.009]^{* * *}$} & {$[0.009]^{* * *}$} & {$[0.010]^{* * *}$} & {$[0.010]^{* * *}$} & {$[0.010]^{* * *}$} \\
\hline \multirow[t]{2}{*}{ Net Contract (1 = yes) } & -0.044 & -0.044 & -0.048 & -0.048 & -0.058 \\
\hline & {$[0.017]^{* *}$} & {$[0.017]^{* *}$} & {$[0.0170]^{* * *}$} & {$[0.0170]^{* * *}$} & {$[0.019]^{* * *}$} \\
\hline \multirow[t]{2}{*}{ Employment Growth (fraction) } & 0.605 & 0.606 & 0.611 & 0.607 & 0.873 \\
\hline & {$[0.242]^{* *}$} & {$[0.242]^{* *}$} & {$[0.241]^{* *}$} & {$[0.240]^{* *}$} & {$[0.321]^{* * *}$} \\
\hline \multicolumn{6}{|l|}{ Age: } \\
\hline \multirow[t]{2}{*}{$<10$ years } & & & 0.121 & 0.134 & 0.131 \\
\hline & & & {$[0.018]^{* * *}$} & {$[0.018]^{* * *}$} & {$[0.020]^{* * *}$} \\
\hline \multirow[t]{2}{*}{$10-20$ years } & & & 0.083 & 0.089 & 0.083 \\
\hline & & & {$[0.014]^{* * *}$} & {$[0.014]^{* * *}$} & {$[0.015]^{* * *}$} \\
\hline \multirow[t]{2}{*}{$20-30$ years } & & & 0.049 & 0.051 & 0.048 \\
\hline & & & {$[0.010]^{* * *}$} & {$[0.010]^{* * *}$} & {$[0.011]^{* * *}$} \\
\hline \multirow[t]{2}{*}{$30-40$ years } & & & 0.046 & 0.048 & 0.043 \\
\hline & & & {$[0.011]^{* * *}$} & {$[0.011]^{* * *}$} & {$[0.012]^{* * *}$} \\
\hline \multirow[t]{2}{*}{ Renovated (1 = yes) } & & & -0.006 & -0.007 & -0.010 \\
\hline & & & {$[0.007]$} & {$[0.007]$} & {$[0.008]$} \\
\hline \multicolumn{6}{|l|}{ Staries: } \\
\hline \multirow[t]{2}{*}{ Intermediate (1 = yes) } & & & & 0.010 & 0.009 \\
\hline & & & & {$[0.009]$} & {$[0.009]$} \\
\hline \multirow[t]{2}{*}{ High $(1=$ yes $)$} & & & & -0.029 & -0.031 \\
\hline & & & & {$[0.012]^{* *}$} & {$[0.013]^{* *}$} \\
\hline \multirow[t]{2}{*}{ Amenities (1=yes) } & & & & 0.047 & 0.053 \\
\hline & & & & {$[0.008]^{* * * *}$} & {$[0.008]^{* * *}$} \\
\hline
\end{tabular}


Table 5.2 (continued)

\begin{tabular}{lccccc} 
Constant & 2.745 & 2.744 & 2.721 & 2.727 & 2.566 \\
& {$[0.139]^{* * *}$} & {$[0.139]^{* * *}$} & {$[0.138]^{* * *}$} & {$[0.138]^{* * *}$} & {$[0.193]^{* * *}$} \\
Sample Size & 8182 & 8182 & 8182 & 8182 & 8182 \\
$\mathrm{R}^{2}$ & 0.71 & 0.71 & 0.71 & 0.72 & 0.74 \\
Adj $R^{2}$ & 0.68 & 0.68 & 0.69 & 0.69 & 0.68 \\
\hline
\end{tabular}

Notes: Each regression also includes 694 dummy variables, one for each locational cluster. Regression (5) also includes an additional 694 dummy variables, one for each green building in the sample. Standard errors are in brackets. Significance at the 0.10, 0.05, and 0.01 levels is indicated by ${ }^{*},{ }^{* *}$, and ${ }^{* * *}$, respectively.

Table 5.3 presents the results when the dependent variable is measured by the logarithm of effective rent. In this formulation, we multiply the rent per square foot of leased space by the fraction of the building which is leased. ${ }^{34}$ When endogenous rent-setting policies are taken into account, the results suggest that the effect of a green rating is even larger. In the simplest model, column (1), the statistical results suggest that a green rating is associated with an 8.5 percent increase in effective rent. When the other hedonic characteristics and amenities of buildings are accounted for in column (4) - as far as possible - the results still indicate an effective premium of more than six percent for rated buildings.

Table 5.3

Regression Results

Commercial Office Rents and Green Ratings

(dependent variable: logarithm of effective rent per square foot)

\begin{tabular}{lccccc}
\hline & $(1)$ & $(2)$ & $(3)$ & $(4)$ & $(5)$ \\
\hline Green Rating (1 = yes) & 0.085 & & 0.082 & 0.064 & \\
& {$[0.024]^{* * *}$} & & {$[0.024]^{* * *}$} & {$[0.023]^{* * *}$} & \\
Energy Star (1 = yes) & & 0.089 & & & \\
LEED (1 = yes) & & {$[0.024]^{* * *}$} & & & \\
& & 0.044 & & & \\
Building Size (millions of sq. ft.) & 0.263 & 0.263 & 0.236 & 0.190 & 0.194 \\
& {$[0.028]^{* * *}$} & {$[0.028]^{* * *}$} & {$[0.028]^{* * *}$} & {$[0.031]^{* * *}$} & {$[0.033]^{* * *}$} \\
Building Class: & & & & \\
Class A (1 = yes) & 0.414 & 0.414 & 0.344 & 0.233 & 0.229 \\
& {$[0.024]^{* * *}$} & {$[0.024]^{* * *}$} & {$[0.026]^{* * *}$} & {$[0.028]^{* * *}$} & {$[0.029]^{* * *}$} \\
Class B (1 = yes) & 0.227 & 0.227 & 0.203 & 0.153 & 0.148 \\
& {$[0.020]^{* * *}$} & {$[0.020]^{* * *}$} & {$[0.020]^{* * *}$} & {$[0.021]^{* * *}$} & {$[0.021]^{* * *}$} \\
Net Contract (1 = yes) & 0.017 & 0.017 & 0.012 & 0.012 & 0.014 \\
& {$[0.036]$} & {$[0.036]$} & {$[0.036]$} & {$[0.036]$} & {$[0.039]$} \\
Employment Growth (fraction) & 0.754 & 0.690 & 0.762 & 0.671 & 0.473 \\
& {$[0.896]$} & {$[0.904]$} & {$[0.896]$} & {$[0.887]$} & {$[0.929]$}
\end{tabular}

34 We may expect property owners to adopt differing asking rent strategies. Ceteris paribus, landlords who quote higher rents will experience higher vacancy rates. 
Table 5.3 (continued)

Age:

$<10$ years

$10-20$ years

$20-30$ years

$30-40$ years

Renovated $(1=$ yes $)$

Stories:

Intermediate (1 = yes)

High $(1=$ yes $)$

Amenities (1=yes)

Constant

Sample Size

$\mathrm{R}^{2}$

Adj $R^{2}$
0.138

$[0.037]^{*}$

0.144

$[0.028]^{* * *}$

0.116

$[0.022]^{* * *}$

0.100

$[0.023]^{* * *}$

0.021

[0.016]
0.181

$037]^{* * *} \quad[0.042]^{* * *}$

$0.151 \quad 0.150$

$[0.028]^{* * *}[0.031]^{* * *}$

$0.116 \quad 0.126$

$[0.022]^{* *} \quad[0.023]^{* * *}$

$0.093 \quad 0.088$

$[0.023]^{* * *}[0.025]^{* * *}$

$0.018 \quad 0.021$

[0.016] [0.016]

Notes: Each regression also includes 694 dummy variables, one for each locational cluster. Regression (5) also includes an additional 694 dummy variables, one for each green building in the sample. Standard errors are in brackets. Significance at the 0.10, 0.05, and 0.01 levels is indicated by $*, " *$, and ${ }^{* * *}$, respectively.

Table 5.4 presents analogous results based upon the smaller sample of 199 green office buildings sold in the 2004-2007 period and the control sample of non-green buildings sold within a quarter mile of those green buildings. These models explain only about half the variation in the dependent variable, selling price per square foot, but the qualitative results are similar. For each of the specifications reported, the variable reflecting certification of a green building is highly significant. As before, when the certification is reported separately for the EnergyStar and the LEED systems, there is no evidence that the latter certification is associated with higher selling prices. There is some evidence that selling prices per square foot are higher when buildings are higher, when they are of higher quality (as measured by class rating) and when they are newer. In contrast to the results reported for the rental sample, it appears that buildings with fewer stories sell for higher prices per square foot. Buildings sold in 2004 were lower in price by $15-17$ percent. 
Table 5.4

Regression Results

Office Sales Prices and Green Ratings 2004- 2007

(dependent variable: sales price in dollars/sq. ft.)

\begin{tabular}{|c|c|c|c|c|c|}
\hline & (1) & (2) & (3) & (4) & (5) \\
\hline \multirow[t]{2}{*}{ Green Rating $(1=$ yes $)$} & 0.170 & & 0.160 & 0.167 & \\
\hline & {$[0.065]^{* * *}$} & & {$[0.065]^{* *}$} & {$[0.065]^{* *}$} & \\
\hline \multirow[t]{2}{*}{ Energy Star $(1=$ yes $)$} & & 0.193 & & & \\
\hline & & {$[0.068]^{* * *}$} & & & \\
\hline \multirow[t]{2}{*}{$\operatorname{LEED}(1=$ yes $)$} & & 0.114 & & & \\
\hline & & [0.168] & & & \\
\hline \multirow[t]{2}{*}{ Building Size (millions of sq. ft.) } & 0.171 & 0.167 & 0.104 & 0.201 & 0.192 \\
\hline & {$[0.090]^{*}$} & {$[0.090]^{*}$} & {$[0.092]$} & {$[0.101]^{* *}$} & {$[0.110]^{*}$} \\
\hline \multicolumn{6}{|l|}{ Building Class: } \\
\hline \multirow[t]{2}{*}{ Class $A(1=$ yes $)$} & 0.168 & 0.164 & 0.037 & 0.107 & 0.145 \\
\hline & {$[0.064]^{* * *}$} & {$[0.064]^{* *}$} & {$[0.075]$} & {$[0.078]$} & {$[0.084]^{*}$} \\
\hline \multirow[t]{2}{*}{ Class B $(1=$ yes $)$} & -0.184 & -0.183 & -0.211 & $-0.180-$ & 0.179 \\
\hline & {$[0.049]^{* * *}$} & {$[0.049]^{* * *}$} & {$[0.051]^{* * *}$} & {$[0.052]^{* * *}$} & {$[0.054]^{* * *}$} \\
\hline \multicolumn{6}{|l|}{ Age: } \\
\hline \multirow[t]{2}{*}{$<10$ years } & & & 0.196 & 0.199 & 0.149 \\
\hline & & & {$[0.108]^{*}$} & {$[0.108]^{*}$} & {$[0.130]$} \\
\hline \multirow[t]{2}{*}{$10-20$ years } & & & 0.196 & 0.224 & 0.226 \\
\hline & & & {$[0.092]^{* *}$} & {$[0.092]^{* *}$} & {$[0.105]^{* *}$} \\
\hline \multirow[t]{2}{*}{$20-30$ years } & & & 0.245 & 0.272 & 0.284 \\
\hline & & & {$[0.065]^{* * *}$} & {$[0.065]^{* * *}$} & {$[0,071]^{* * *}$} \\
\hline \multirow[t]{2}{*}{$30-40$ years } & & & 0.226 & 0.250 & 0.281 \\
\hline & & & {$[0.074]^{* * *}$} & {$[0.075]^{* * *}$} & {$[0.085]^{* * *}$} \\
\hline \multirow[t]{2}{*}{ Renovated (1 = yes) } & & & -0.099 & -0.091 & -0.075 \\
\hline & & & {$[0.044]^{* *}$} & {$[0.044]^{* *}$} & {$[0.048]$} \\
\hline \multicolumn{6}{|l|}{ Stories: } \\
\hline \multirow[t]{2}{*}{ High (1 = yes) } & & & & -0.184 & -0.230 \\
\hline & & & & {$[0.075]^{* *}$} & {$[0.084]^{* * *}$} \\
\hline \multirow[t]{2}{*}{ Intermediate (1 = yes) } & & & & -0.177 & -0.182 \\
\hline & & & & {$[0.056]^{* * *}$} & {$[0.061]^{* * *}$} \\
\hline \multirow[t]{2}{*}{ Amenities (1=yes) } & & & & -0.041 & -0.046 \\
\hline & & & & {$[0.046]$} & {$[0.050]$} \\
\hline
\end{tabular}




\begin{tabular}{lccccc}
$\begin{array}{l}\text { Table } 5.4 \text { (continued) } \\
\text { Year of Sale: }\end{array}$ & & & & & \\
$2006(1=$ yes) & 0.023 & 0.024 & 0.028 & 0.026 & 0.058 \\
& {$[0.050]$} & {$[0.050]$} & {$[0.050]$} & {$[0.049]$} & {$[0.054]$} \\
$2005(1=$ yes) & -0.036 & -0.035 & -0.035 & -0.045 & -0.031 \\
& {$[0.052]$} & {$[0.052]$} & {$[0.051]$} & {$[0.051]$} & {$[0.056]$} \\
$2004(1=$ yes $)$ & -0.157 & -0.156 & -0.155 & -0.175 & -0.149 \\
& {$[0.057]^{* * *}$} & {$[0.057]^{* * *}$} & {$[0.057]^{* * *}$} & {$[0.057]^{* * *}$} & {$[0.062]^{* *}$} \\
Constant & 5.288 & 5.292 & 5.248 & 5.372 & 5.372 \\
& {$[0.734]^{* * *}$} & {$[0.734]^{* * *}$} & {$[0.733]^{* * *}$} & {$[0.732]^{* * *}$} & {$[0.752]^{* * *}$} \\
& & & & & \\
Sample Size & 1816 & 1816 & 1816 & 1816 & 1816 \\
$\mathrm{R}^{2}$ & 0.43 & 0.43 & 0.44 & 0.44 & 0.49 \\
Adj R & 0.35 & 0.35 & 0.36 & 0.37 & 0.34 \\
\hline
\end{tabular}

Notes: Each regression also includes 99 dummy variables, one for each locational cluster. Regression (5) also includes an additional 204 dummy variables, one for each green building in the sample. Standard errors are in brackets. Significance at the $0.10,0.05$, and 0.01 levels is indicated by $*,{ }^{* *}$, and ${ }^{* * *}$, respectively,

The results reported in Tables 5.3, 5.4, and 5.5 are robust to other variations in the hedonic characteristics included on the right-hand side in the vector $x$. They are not robust to the exclusion of the dummy variables identifying the neighborhoods in which the sample and control variables are located. The distribution of green-rated buildings is not random within urban areas in the U.S. and if this is not taken into account explicitly, the statistical results can be highly misleading. ${ }^{35}$

Figure 5.4 presents the distribution of the rent and value premiums for each of the 694 green buildings in the rental sample and the 199 green buildings which were sold between 2004 and 2007. Figure 5.4A reports the premium in rent per square foot, using the results reported in column (5) of Table 5.2; Figure 5.4B reports the premium in effective rent per square foot, using the results reported in column (5) of Table 5.3. Figure 5.4C reports the distribution of premiums in selling price from column (5) of Table 5.4. The figure demonstrates that the values of the estimated rent premiums vary across buildings, and in at least a few cases, the estimated effects are negative. However, a simple t-test indicates that the probability that the mean rent premium or value is negative for this sample of buildings is miniscule. For rents, the probability is 0.0258 . For effective rents, it is 0.0017 , and for selling prices the probability that the mean value premium for green buildings is zero is 0.0009 .

35 Results from additional specifications and specifications that do not identify specific clusters are available on request (or online at http://urbanpolicy.berkeley.edul. 
Figure 5.4

Distribution of Regression Estimates of the

Increments to Rents or Market Value for Green Buildings

A. Rent (based on Table 5.2, Column 5)

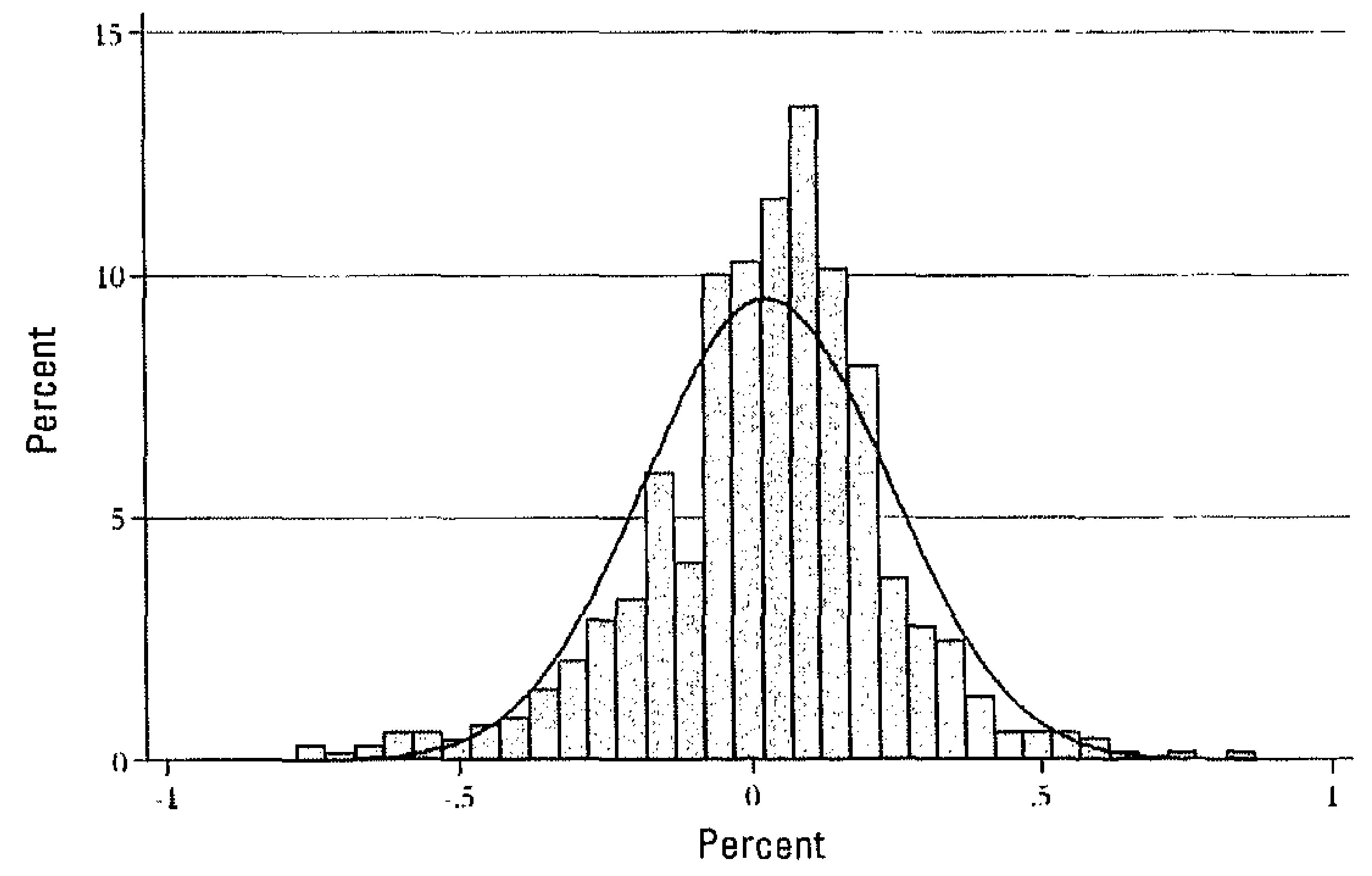

B. Effective Rent (based on Table 5.3, Column 5)

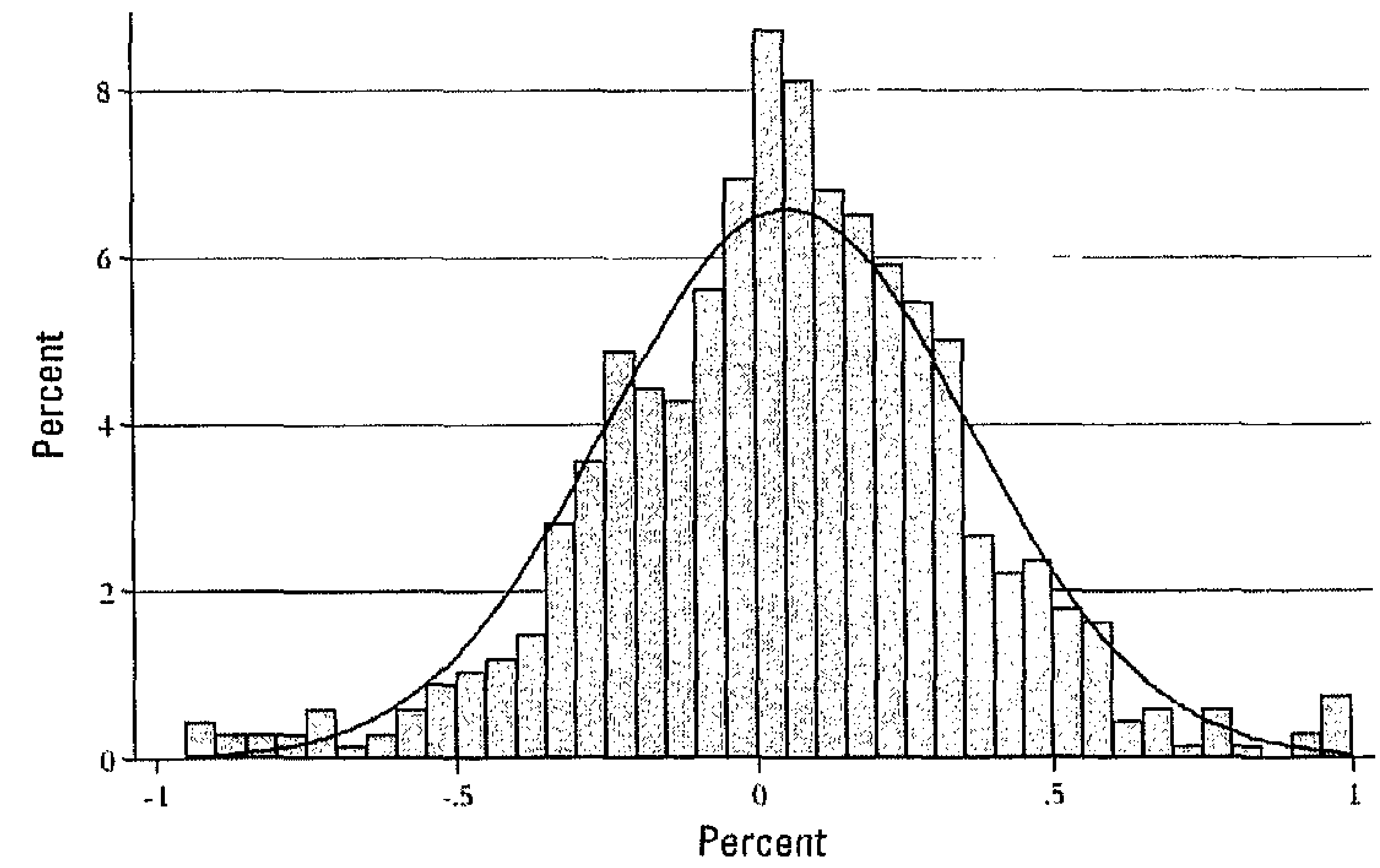




\section{Market Value (based on Table 5.4, Column 5)}

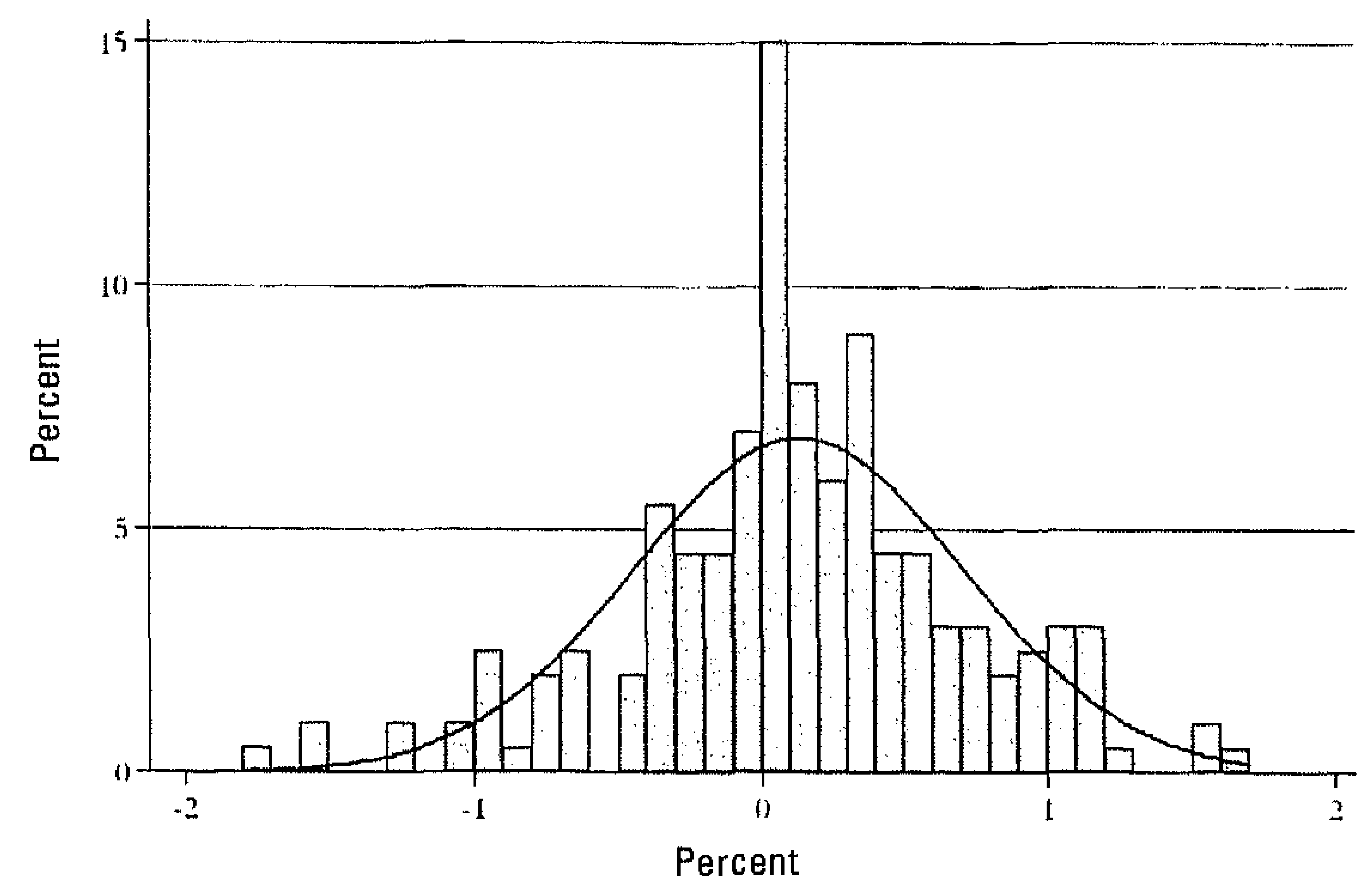

The rent premium associated with the label on any building represents the joint effects of the engineering efficiency of the building together with other unmeasured, but presumably important, attributes of the building. If we had access to the engineering attributes underlying the rating and the thermal conditions associated with each individual cluster, it would be possibly, at least in principle, to distinguish the engineering aspects of the Energy Star label from other valuable attributes of the label.

It is possible to obtain climatic information associated with each cluster (at the level of the CBSA, the Core Based Statistical Area), but it has not been possible to obtain access to the engineering properties of the rated buildings ${ }^{36}$ Thus it is not yet possible to distinguish between the effects on profitability of better engineering or design conditions and the profitability of other attributes of the label - including its signal value.

A hint about the importance of the thermal properties in affecting profitability is contained in regression estimates of equation (5.2) of the following form:

$\hat{\delta}_{n}=-0.514+0.070 \log 0$

$$
(0.300)(0.037)
$$

Where $\hat{\delta}_{n}$ is the estimate of the effective rent premium for the rated building in cluster $n$ (as shown in Figure 5.4). and $D$ is the number of degree days (i.e., heating and cooling degree days) associated with cluster $n$. As indicated by the standard errors (in parentheses), local climate conditions do make the label significantly more valuable - presumably the attributes measured by engineers at the time of the application affect the profitability of the label as well. But currently available data do not permit us to distinguish the economic effects of the ratings from the effects of the superior engineering attributes they symbolize.

36 However, exactly the information required to analyze this important issue is maintained by the Energy Star program of the U.S. Environmental Protection Agency. For each rated building, Energy Star records a "Statement of Energy Performance" reporting the site energy use, energy intensity, and emissions of that building. It is precisely this information, which varies for each observation in our sample, that would distinguish the profitability of the engineering attributes of green-rated buildings from other valuable signals associated with a green rating. 


\subsection{Conclusions}

This chapter reports the only systematic evidence on the economic value of certification of green buildings to the U.S. economy. In contrast to the anecdotal evidence on the economic effects of investments in environmentally sustainable building, the research reported here is based upon impersonal market comparisons.

For each commercial building in the country which has obtained a LEED and or Energy Star label, we identified a control group consisting of all commercial properties located within about 1300 feet. For this sample - about 10,000 buildings divided into about 900 clusters, each containing one labeled building and nearby unlabeled buildings - we relate market rents of the properties to the hedonic characteristics of properties, within very small geographical areas.

The results clearly indicate the importance of a green label in affecting the market rents of comparable commercial space in close proximity. The results suggest that the otherwise commercial building with an environmental certification will rent for about two percent more per square foot; the difference in effective rent is estimated to be about six percent per square foot. The increment to the selling price may be as much as 16 percent.

These are large effects. For example, the average effective rent for the 7488 control buildings in the sample of rental office buildings is $\$ 23.53$ per square foot. At the average size of these buildings, the estimated annual rent increment for a green building is almost $\$ 309,000$. At prevailing capitalization rates of six percent, the incremental value of a green building is estimated to be about $\$ 5.1$ million more than the value of a comparable unrated building nearby. The average selling price for the 1617 control buildings in the sample of buildings sold in the 2004-2007 period is $\$ 34.73$ million. Ceteris paribus, the incremental value of a green building is estimated to be about $\$ 5.9$ million more than the value of a comparable unrated building nearby.

As noted, we do not yet have access to the information that would allow us to distinguish the market value of energy savings and conservation from the other valuable attributes of a label. But this should be a high priority for future research. 


\section{Appendix 5.A}

Regression Results

Commercial Office Rents and Green Ratings for Net Rental Contracts

(dependent variable: logarithm of rent per square foot)

\begin{tabular}{|c|c|c|c|c|c|}
\hline & (1) & (2) & (3) & (4) & (5) \\
\hline \multirow[t]{2}{*}{ Green Rating (1 = yes) } & 0.091 & & 0.075 & 0.083 & \\
\hline & {$[0.038]^{* *}$} & & {$[0.037]^{* *}$} & {$[0.037]^{* *}$} & \\
\hline \multirow[t]{2}{*}{ Energy Star $(1=$ yes $)$} & & 0.081 & & & \\
\hline & & {$[0.040]^{* *}$} & & & \\
\hline \multirow[t]{2}{*}{$\operatorname{LEED}(1=$ yes $)$} & & 0.181 & & & \\
\hline & & {$[0.119]$} & & & \\
\hline \multirow[t]{2}{*}{ Building Size (millions of sq. ft.) } & -0.049 & -0.052 & 0.009 & -0.063 & -0.096 \\
\hline & {$[0.060]$} & {$[0.060]$} & {$[0.058]$} & {$[0.071]$} & {$[0.076]$} \\
\hline \multirow[t]{2}{*}{ Fraction Occupied } & 0.074 & 0.073 & 0.054 & 0.021 & -0.026 \\
\hline & [0.102] & {$[0.102]$} & [0.096] & [0.099] & {$[0.104]$} \\
\hline \multicolumn{6}{|l|}{ Building Class: } \\
\hline \multirow[t]{2}{*}{ Class $A(1=$ yes $)$} & 0.316 & 0.318 & 0.332 & 0.335 & 0.316 \\
\hline & {$[0,122]^{* *}$} & {$[0.122]^{* *}$} & {$[0.111]^{* * *}$} & {$[0.108]^{* * *}$} & {$[0.105]^{* * *}$} \\
\hline \multirow[t]{2}{*}{ Class B $(1=$ yes $)$} & 0.230 & 0.230 & 0.211 & 0.200 & 0.184 \\
\hline & {$[0.121]^{*}$} & {$[0.121]^{*}$} & {$[0.110]^{*}$} & {$[0.108]^{*}$} & {$[0.105]^{*}$} \\
\hline \multirow[t]{2}{*}{ Employment Growth (fraction) } & 0.000 & 0.000 & 0.000 & 0.000 & 0.000 \\
\hline & {$[0.000]$} & {$[0.000]$} & {$[0.000]$} & {$[0.000]$} & {$[0.000]$} \\
\hline \multicolumn{6}{|l|}{ Age: } \\
\hline \multirow[t]{2}{*}{$<10$ years } & & & 0.101 & 0.148 & 0.176 \\
\hline & & & {$[0.067]$} & {$[0.070]^{* *}$} & {$[0.082]^{* *}$} \\
\hline \multirow[t]{2}{*}{$10-20$ years } & & & -0.152 & -0.104 & .0 .104 \\
\hline & & & {$[0.046]^{* * *}$} & {$[0.049]^{* *}$} & {$[0.055]^{*}$} \\
\hline \multirow[t]{2}{*}{$20-30$ years } & & & -0.084 & -0.031 & -0.026 \\
\hline & & & {$[0.050]^{*}$} & {$[0.052]$} & {$[0.058]$} \\
\hline \multirow[t]{2}{*}{$30-40$ years } & & & -0.098 & -0.054 & -0.019 \\
\hline & & & {$[0.045]^{* * *}$} & {$[0.046]$} & {$[0.049]$} \\
\hline \multirow{2}{*}{ Renovated (1 = yes) } & & & -0.042 & -0.030 & -0.037 \\
\hline & & & {$[0.038]$} & [0.038] & {$[0.040]$} \\
\hline \multicolumn{6}{|l|}{ Stories: } \\
\hline \multirow[t]{2}{*}{ Intermediate (1 = yes) } & & & & -0.056 & -0.116 \\
\hline & & & & {$[0.042]$} & {$[0.046]^{* *}$} \\
\hline \multirow[t]{2}{*}{ High (1 = yes) } & & & & -0.029 & -0.042 \\
\hline & & & & {$[0.046]$} & {$[0.048]$} \\
\hline \multirow[t]{2}{*}{ Amenities (1=yes) } & & & & 0.087 & 0.103 \\
\hline & & & & {$[0.031]^{* * *}$} & {$[0.036]^{* * *}$} \\
\hline \multirow[t]{2}{*}{ Constant } & 3.480 & 3.241 & 3.396 & 3.363 & 3.351 \\
\hline & {$[0.179]^{* * *}$} & {$[0.234]^{* * *}$} & {$[0.179]^{* * *}$} & {$[0.178]^{* * *}$} & {$[0.180]^{* * *}$} \\
\hline Sample Size & 276 & 276 & 276 & 276 & 276 \\
\hline $\mathrm{R}^{2}$ & 0.95 & 0.95 & 0.96 & 0.96 & 0.97 \\
\hline Adj R & 0.86 & 0.86 & 0.89 & 0.89 & 0.90 \\
\hline
\end{tabular}




\begin{tabular}{|c|c|c|c|c|c|}
\hline \multicolumn{6}{|c|}{$\begin{array}{l}\text { Commercial Office Rents and Green Ratings for Net Rental Contracts } \\
\text { (dependent variable: logarithm of effective rent per square foot) }\end{array}$} \\
\hline & (1) & (2) & (3) & $(4)$ & (5) \\
\hline Green Rating (1 = yes) & $\begin{array}{r}0.078 \\
{[0.064]}\end{array}$ & & $\begin{array}{r}0.103 \\
{[0.065]}\end{array}$ & $\begin{array}{r}0.105 \\
{[0.064]}\end{array}$ & \\
\hline Energy Star (1 = yes) & & $\begin{array}{r}0.066 \\
{[0.068]}\end{array}$ & & & \\
\hline LEED (1 = yes $)$ & & $\begin{array}{r}0.177 \\
{[0.199]}\end{array}$ & & & \\
\hline Building Size (millions of sq. ft.) & $\begin{array}{r}0.033 \\
{[0.100]}\end{array}$ & $\begin{array}{r}0.030 \\
{[0.101]}\end{array}$ & $\begin{array}{r}0.032 \\
{[0.102]}\end{array}$ & $\begin{array}{c}-0.205 \\
{[0.120]^{*}}\end{array}$ & $\begin{array}{l}-0.175 \\
{[0.135]}\end{array}$ \\
\hline Building Class: & & & & & \\
\hline Class A $(1=$ yes $)$ & $\begin{array}{c}0.503 \\
{[0.202]^{* *}}\end{array}$ & $\begin{array}{c}0.505 \\
{[0.203]^{* *}}\end{array}$ & $\begin{array}{c}0.481 \\
{[0.193]^{* *}}\end{array}$ & $\begin{array}{c}0.447 \\
{[0.186]^{* *}}\end{array}$ & $\begin{array}{c}0.407 \\
{[0.188]^{* *}}\end{array}$ \\
\hline Class $B(1=$ yes $)$ & $\begin{array}{c}0.361 \\
{[0.202]^{*}}\end{array}$ & $\begin{array}{c}0.361 \\
{[0.202]^{*}}\end{array}$ & $\begin{array}{c}0.335 \\
{[0.193]^{*}}\end{array}$ & $\begin{array}{c}0.311 \\
{[0.186]^{*}}\end{array}$ & $\begin{array}{r}0.282 \\
{[0.188]}\end{array}$ \\
\hline Employment Growth (fraction) & $\begin{array}{r}0.000 \\
{[0.000]}\end{array}$ & $\begin{array}{r}0.000 \\
{[0.000]}\end{array}$ & $\begin{array}{r}0.000 \\
{[0.000]}\end{array}$ & $\begin{array}{r}0.000 \\
{[0.000]}\end{array}$ & $\begin{array}{r}0.000 \\
{[0.000]}\end{array}$ \\
\hline Age: & & & & & \\
\hline$<10$ years & & & $\begin{array}{c}0.301 \\
{[0.114]^{* * *}}\end{array}$ & $\begin{array}{c}0.390 \\
{[0.117]^{* * *}}\end{array}$ & $\begin{array}{c}0.451 \\
{[0.141]^{* * *}}\end{array}$ \\
\hline $10-20$ years & & & $\begin{array}{c}-0.094 \\
{[0.080]}\end{array}$ & $\begin{array}{c}-0.052 \\
{[0.084]}\end{array}$ & $\begin{array}{r}-0.071 \\
{[0.099]}\end{array}$ \\
\hline $20-30$ years & & & $\begin{array}{r}-0.018 \\
{[0.088]}\end{array}$ & $\begin{array}{r}0.045 \\
{[0.089]}\end{array}$ & $\begin{array}{r}0.010 \\
{[0.104]}\end{array}$ \\
\hline $30-40$ years & & & $\begin{array}{r}0.027 \\
{[0.077]}\end{array}$ & $\begin{array}{r}0.092 \\
{[0.078]}\end{array}$ & $\begin{array}{r}0.106 \\
{[0.087]}\end{array}$ \\
\hline Renovated (1 = yes) & & & $\begin{array}{r}0.032 \\
{[0.066]}\end{array}$ & $\begin{array}{r}0.044 \\
{[0.064]}\end{array}$ & $\begin{array}{r}0.038 \\
{[0.072]}\end{array}$ \\
\hline Stories: & & & & & \\
\hline Intermediate (1 = yes) & & & & $\begin{array}{c}-0.041 \\
{[0.073]}\end{array}$ & $\begin{array}{l}-0.086 \\
{[0.082]}\end{array}$ \\
\hline High $(1=$ yes $)$ & & & & $\begin{array}{r}0.114 \\
{[0.076]}\end{array}$ & $\begin{array}{r}0.095 \\
{[0.084]}\end{array}$ \\
\hline Amenities (1=yes) & & & & $\begin{array}{c}0.139 \\
{[0.054]^{* *}}\end{array}$ & $\begin{array}{c}0.133 \\
{[0.064]^{* *}}\end{array}$ \\
\hline Constant & $\begin{array}{l}7.004 \\
{[0.336]^{* *}}\end{array}$ & $\begin{array}{l}7.778 \\
{[0.359]^{* * *}}\end{array}$ & $\begin{array}{l}7.020 \\
{[0.329]^{* * *}}\end{array}$ & $\begin{array}{l}7.136 \\
{[0.319]^{* * *}}\end{array}$ & $\begin{array}{l}6.997 \\
{[0.330]^{* * *}}\end{array}$ \\
\hline Sample Size & 275 & 275 & 275 & 275 & 275 \\
\hline $\mathrm{R}^{2}$ & 0.89 & 0.89 & 0.91 & 0.92 & 0.94 \\
\hline Adj $R^{2}$ & 0.73 & 0.73 & 0.76 & 0.78 & 0.78 \\
\hline
\end{tabular}


Appendix 5.C

Distribution of $t$ ratios of the Hypotheses Testing

Increments to Rents or Market Value for Green Buildings

A. Rent $\left(\mathrm{H}_{0}:\right.$ Rent Increment $=0.019-$ based on Table 5.2, Column 5)

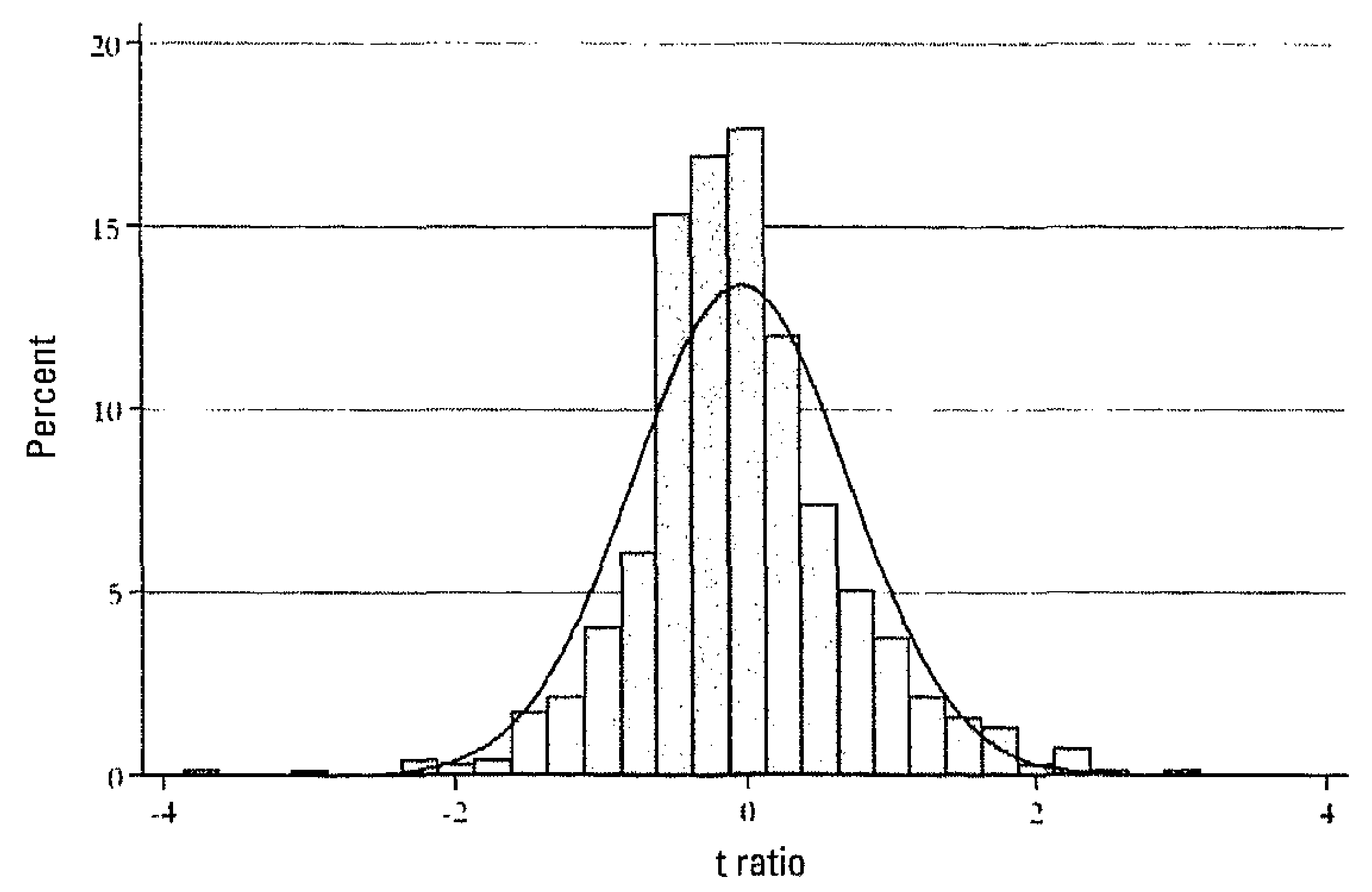

B. Expected Rent $\left(\mathrm{H}_{0}\right.$; Rent Increment $=0.064-$ based on Table 5.3, Column 5)

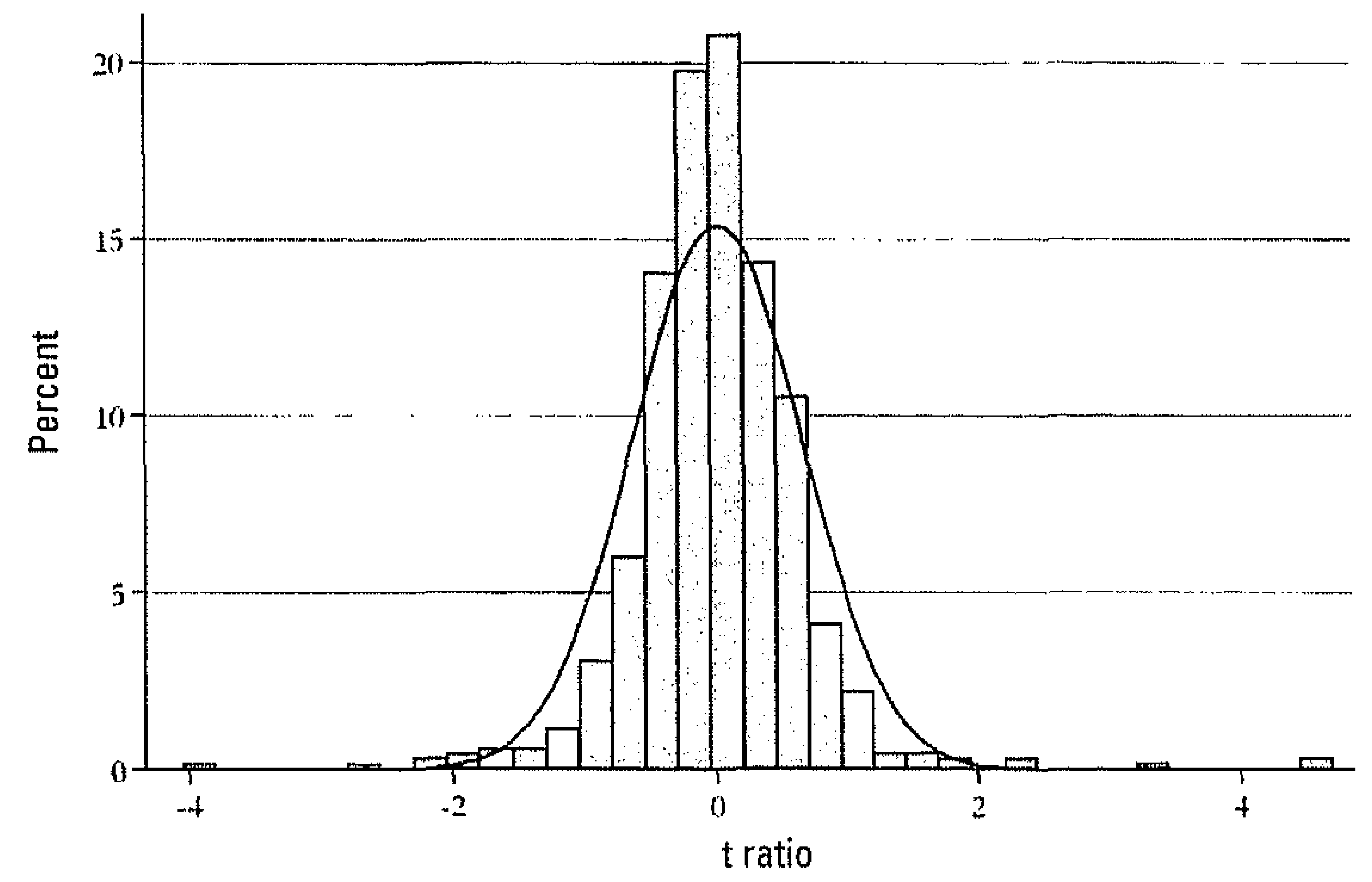


Chapter 5. Doing Well by Building Green?

C. Market Value $\left(H_{0}\right.$ : Rent Increment $=0.167-$ based on Table 5.4, Column 5)

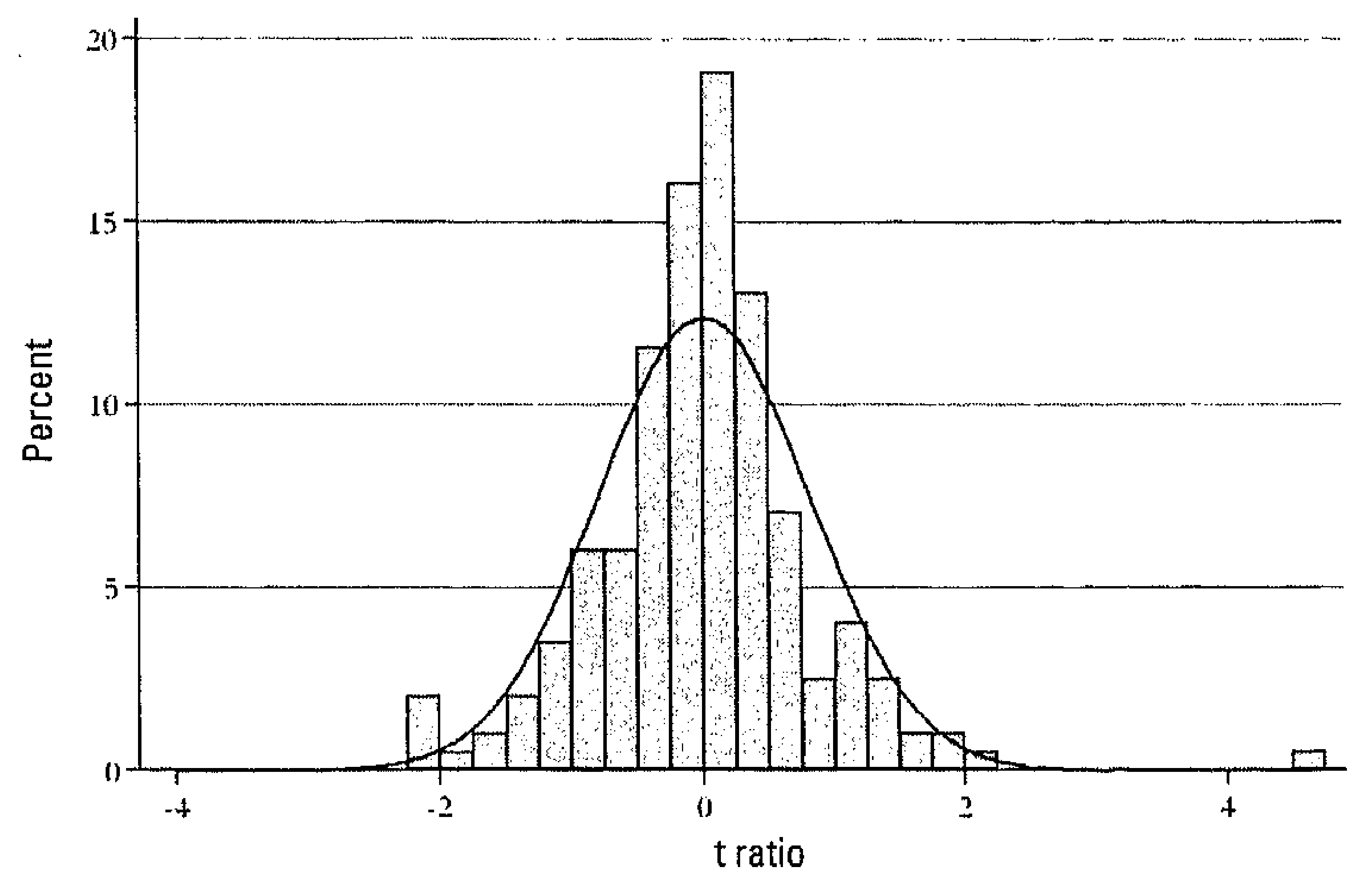


Why Companies Rent

Green: CSR and the Role of Real Estate 


\section{Why Companies Rent Green: CSR and the Role of Real Estate}

\subsection{Introduction}

The TNT Group, a global express delivery service headquartered in the Netherlands, recently announced to move its operations to three newly to be developed green office buildings. The decision is part of the broader corporate social responsibility (CSR) policy of the TNT Group, which states that 'it is our aim to invest in mitigating our impact on the environment'. This is but one of the numerous examples of firms moving into 'green' buildings, indicating that for companies with a strong focus on sustainability, real estate has become an integrated element of the corporate social responsibility policy, thereby even influencing strategic decision-making.

The behavior of corporate tenants can have important implications for the shift to a more sustainable built environment, as increased demand triggers if not forces suppliers to rapidly adapt to high environmental standards. Moreover, there is a financial incentive for the property investment industry as well, as shifting preferences of tenants affect rental rates on commercial buildings and the volatility of the rental flow. If tenants increasingly decide to lease green space rather than regular office space, then a differential in rental rates between green and regular buildings is bound to develop. Moreover, it is possible that the non-green commercial properties will depreciate faster, and occupancy rates might be lower and more volatile.

In a recent paper, Eichholtz, Kok and Quigley (2008b) study the economic value of office buildings with a green label, and find that landlords of these 'green' buildings are able to command a rental and sales premium over regular, non-green office buildings. This implies that a specific group of tenants is apparently willing to pay a premium to lease green space. Moreover, the results show that occupancy rates are higher and less volatile in commercial office buildings with a green label. But why do some firms have a preference for green office space? Which firms want to rent green? Understanding the motivation for this corporate sustainability responsiveness is important for two reasons. First, for the property sector to engage in the development of sustainable commercial real estate and for the investment community to finance these properties, it is important to identify the characteristics of corporate tenants that are potentially interested in leasing green space. Second, a better understanding of firms actively engaged in socially responsible behavior, allows researchers, managers and policy makers to determine the efficiency of market measures, voluntary measures, legislation, and command and control mechanisms with respect to sustainability (Bansal and Roth, 2000).

We identify four drivers influencing environmental decision-making with respect to space use. First, pursuing an active CSR policy can be economically rational, as operational cost of green buildings may be lower and 
employee productivity and well-being may be enhanced. Second, the occupancy of sustainable buildings can have indirect economic effects, such as employee attraction and retention, through an improved reputation. A green corporate headquarter may act as a signal to stakeholders - customers, investors and employees - that a firm is not just waving a green flag, but has a long-run commitment to a CSR policy. Third, by voluntarily adapting to the highest legal environmental standards now, firms can anticipate future legislation and avoid the risk of costly litigation later. Fourth, although most attention of investors is focused on the 'triple bottom line', in which the combination of economic, environmental and social value are optimized, there is a distinct group of corporate tenants for which non-financial utility from pursuing an active CSR policy exceeds the benefits of monetary gains. Non-profit organizations and governments can therefore be actively engaged in CSR, before purely profitmaximizing firms can.

Following these four value drivers, we propose that specific industries, for example those in the space-intensive tertiary sector or with non-sustainable operations, might be more willing to lease green space, even if this implies paying premium rents. We test these propositions exploiting a dataset of office buildings with an Energy Star or LEED-rating. We collect data on the tenant identity and industry characteristics of tenants in these buildings and construct a control sample of regular office buildings at the same location. Using data on more than 3,100 tenants in 1,180 green office buildings, and on a control sample of approximately 8,000 tenants in 4,000 regular office buildings, we find that the government and government-related organizations are systematically more likely to lease green space rather than regular office space compared to the average tenant. Furthermore, descriptive evidence shows that a substantial number of firms in the oil and banking industry are among the largest occupiers of green office buildings.

The rest of chapter 6 is organized as follows. In Section 6.2 , we shortly discuss the literature on CSR and financial performance, and we identify four drivers that might explain why firms lease green space. Then, we formulate propositions as to which specific industries are most likely to rent green. The third section provides an overview of the data and descriptive statistics. Section 6.4 contains method and results, and Section 6.5 concludes.

\subsection{CSR and Real Estate}

Although previously despised by some economists (Friedman, 1970), CSR is increasingly popular among business leaders and has become an important element in strategic decision-making. Besides, the business case for sustainability is getting stronger, since numerous empirical studies have shown that companies taking CSR into account outperform in terms of operating performance and stock performance (see Margolis and Walsh, 2003, for an overview). The investment community has embraced socially responsible investments (SRI) equally enthusiastically, witnessed by the rapid growth in the number of SRI mutual funds: SRI assets under management increased from $\$ 639$ billion in 1995 to $\$ 2.71$ trillion in 2007 (SIF, 2007). However, evidence on the performance of socially responsible investments is still inconclusive (see Renneboog et al. 2008 for an overview)

In evaluating socially responsible investment decisions, investors mostly focus on issues such as the impact of a firm's operations on the environment, treatment of employees and the social role of the firm in the broader society - based on SRI indices, such as those provided by Kinder, Domini and Lydenberg (KLD), Innovest or 
the Dow Jones Sustainability Index. However, besides the traditional CSR factors, external agents are now increasingly screening firms on their corporate real estate and leasing decisions, as it is recognized that commercial real estate is potentially quite important in matters of environmental sustainability.

Indeed, anecdotal evidence shows that the property sector accounts for forty percent of U.S. energy consumption and 38 percent of U.S. $\mathrm{CO}_{2}$ emissions. ${ }^{37}$ Awareness of these facts has lead to a range of different environmental rating systems for commercial properties, such as the Leadership in Energy and Environment Design (LEED) and Energy Star in the United States, BREEAM in the United Kingdom, and GreenStar in Australia. These environmental labels provide both landlords and tenants with a yardstick to measure the 'greenness' of properties.

Incorporating sustainability in real estate investment decisions seems to pay off. In a recent paper, Eichholtz, Kok and Quigley (2008b) provide evidence that rents and transaction prices in a sample of green office buildings exceed those paid in regular office buildings, while controlling for quality and location-specific characteristics. Decomposition of the 'green' premium would provide more insight in the exact value drivers, but the results provide an indication that tenants might be willing to pay a premium for green office space.

However, the utility from leasing green space differs across tenants; corporate tenants may have a multiattribute utility function that is not only based on the standard risk-reward optimization but that also incorporates a set of corporate and societal values (Bollen, 2008). If such values indeed matter to firms, we can expect tenants to derive non-financial utility from leasing space in green buildings, and, more importantly, to obtain indirect economic advantage from actively pursuing an environmental policy. In the case of CSR, financial and nonfinancial utility are not mutually exclusive.

Adapting the framework of Bansal and Roth (2000), we define four underlying drivers that might induce social responsiveness in corporate real estate decision-making: direct economic benefits, indirect benefits, risk avoidance, and ethical motives. Based on these drivers, we formulate propositions as to which industries may be most responsive to engage in CSR-driven real estate decision-making.

\subsubsection{Drivers of CSR Adoptiveness in Real Estate}

\subsubsection{Direct Economic Benefits}

CSR can have a direct effect on the economic bottom line of firms. Under the traditional view, CSR leads to an inherent conflict between maximizing financial value for shareholders and maximizing social welfare (Baumol, 1991, Friedman, 1970, Shleifer, 2004). However, an increasing number of studies show that incorporating corporate social responsibility in the strategy of the firm does not only maximize social welfare, but also maximizes financial value, for example through lower operating cost and increased efficiency (Porter and Van der Linde, 1995). Indeed, for real estate, energy - an important element of sustainability - represents a substantial cost of building operations. These costs can be decreased through energy efficiency measures that are often part of green buildings design. Anecdotal evidence shows that green buildings on average use 30 percent less energy as compared to conventional buildings (Kats, 2003). Thus, leasing space in more energy efficient buildings can have a direct impact on the costs of corporate housing.

37 U.S. Department of Energy, 2006. 
For firms to lease space in green buildings, another major potential benefit is the increase in employee productivity. Numerous studies have shown that a strong relation exists between a building's internal environment (e.g. indoor air quality) and employee health and productivity. Moreover, monetary gains of reduced sick leave and productivity gains are substantial: although estimates are still crude, benefits seem to exceed costs by an astonishing factor of 18 to 47 (Apte, Fisk and Daisey, 2000, Fisk and Rosenfeld, 1997). The enhanced indoor air quality following from an improved building structure, and from better heating, cooling and ventilation systems is most beneficial for space-intensive firms, i.e. that have operations primarily located in office buildings, such as for example firms in the tertiary sector.

\subsubsection{Indirect Economic Benefits}

Economic opportunities following from relocation of corporate activities in green buildings might as well arise indirectly. The ultimate driver of these secondary - often hard to measure - benefits is an improved corporate reputation. Fombrun (1996) argues that a firm's reputation is a factor of credibility, trustworthiness, reliability and responsibility. Responsibility in itself is a function of environmental, financial and social behavior (Miles and Covin, 2000). The continuum in adaptation of environmental and social behavior ranges from simply complying with legislation to proactively incorporating CSR in daily operations. Leasing space in a green building may send a clear signal of environmental and social awareness, i.e. about the superior social responsibility of tenants. In the end, it is the real implementation of CSR policies rather than the painless and simple policy commitment that is necessary to reap the business benefits of CSR (Ramus and Montiel, 2005).

The position of a firm in the CSR continuum is partially determined by the extent to which stakeholder pressure can affect corporate decision-making. Stakeholder theory predicts that firms pay most attention to the largest and most powerful corporate stakeholders: investors, customers and employees (Mitchell, Agle and Wood, 1997).

First, there is an increasing awareness amongst investors regarding the financial impact of inadequate environmental management, and some segments of the investment community will avoid investing in corporations that cause social injury or environmental damage (Spicer, 1978). Indeed, in a recent study, Hong and Kacperczyk (2007) show that institutional investors (such as pension funds, university endowments, banks and insurance companies) are systematically underinvested in so-called 'sin' stocks. This is confirmed by anecdotal evidence, as major pension funds such as CaIPERS, California and ABP, Netherlands, have publicly announced to abstain from investments in companies with socially unaccepted operations. In a more proactive stance, CalPERS has initiated one of the first green property funds: the Hines CalPERS Green Development Fund. This fund was formed in August 2006 and solely develops sustainable office buildings that are certified through the Leadership in Energy and Environmental Design (LEED) program. Thus, a green reputation may facilitate access to institutional capital.

If leasing green office space leads to a superior reputation, this may enable firms to attract investors more easily and at better market rates (Milgrom and Roberts, 1986). Although this strand of literature is still at an infant stage, some empirical studies indeed show that companies with high environmental and social engagement scores are able to obtain better credit ratings, thereby lowering the cost of debt (Bassen, Meyer and Schlange, 2006), and have a lower implied cost of equity (Derwall, 2007). Especially companies that are frequent users of 
the public capital market would profit from a lower cost of debt or equity.

Second, as Vandermerwe and Oliff (1990) point out, 'customers drive corporations green'. Firms operating in a competitive market can no longer afford to ignore the calls from customers to incorporate environmental responsiveness in manufacturing, $R \& D$ and marketing. With the green movement going mainstream, a broad base of end-consumers is now screening firms on their social and environmental engagement. This can pay off: a superior reputation - for example through ethical behavior - may enable firms to increase sales or to charge premium prices (Creyer and Ross, 1997, Klein and Leffler, 1981). The importance of reputation amongst customers strongly depends on the domain in which a firm operates. Reputation effects are for example important for the largest and most visible firms in an industry, as these companies, like McDonalds, Starbucks and WalMart, are usually under the direct scrutiny of end-consumers (Fombrun and Shanley, 1990). The availability of information from investment analysts and CSR data providers might benefit large firms disproportionally, but this simultaneously increases stakeholder pressure to actively engage in sustainable investments.

Alternatively, for those involved in risky technologies (e.g. nuclear or biotechnology), national and international public policy debates (e.g. active in China or the Middle-East), or operating in controversial product-markets (e.g. tobacco or weapons), having a CSR policy seems to be a way to change a negative image or to offset a bad reputation, although Strahilevitz (2003) documents that CSR activities generally do not enhance the reputation of firms that are perceived to be unethical. This holds especially for firms supporting causes that are related to their own business, e.g. a tobacco company supporting a cancer foundation, which might increase the believe of firmserving salience (Foreh and Grier, 2003). Firms with a bad reputation that want to change consumer perception through engagement in CSR are most successful when sincerely committed to 'the good cause' (Yoon, GurhanCanli and Bozok, 2006). Leasing green space could potentially help in offsetting a negative corporate image or to improve the reputation.

Third, a superior reputation may enable firms to attract and retain a better workforce (Turban and Greening, 1997). The traditional attitude towards employees viewed them as no different from any other input in the production process (Taylor, 1911). However, human capital is a key source of value creation in many modern firms (Zingales, 2000). Attraction and retention of employees is especially important in most Western economies, where skilled employees will soon be a scarce good, due to the shrinking labor population. Moreover, a recent paper by Edmans (2007) shows that employee satisfaction is positively related to financial performance, where employee satisfaction is driven by for example pecuniary benefits as well as superior working conditions. Related to green office space, anecdotal evidence shows that these buildings offer a very high standard of workspace quality. This is not only related to acoustical quality or visual comfort, but also to modern architecture, open workspace and location in the proximity of public transport. These factors may enable a firm to attract and retain high-skilled employees.

\subsubsection{Risk Avoidance}

Governmental legisiation is a key driver of corporate social responsiveness. This is economically rational: non-complying with legislation may be costly. A large number of U.S. companies are litigated each year due to violation of environmental laws, although the likelihood of becoming target of environmental litigation is strongly dependent on the industry type and the location of operations. For example, firms in environmentally sensitive industries are more exposed to media visibility, which shapes the public's view of a firm's activities (Fombrun and 
Shanley, 1990). The litigation costs can be direct, through administrative and civil penalties, or through negative market responses following public announcement of an environmental lawsuit (Kassinis and Vafeas, 2002). But litigation costs can also be indirect, following reputation losses. Especially in hazardous and resource-intensive industries, it is likely that the monetary gains from going beyond complying with rules and regulations will largely offset the initial investment. Although the real estate sector can not be classified as a particularly hazardous industry, corporate tenants might still be vulnerable to costly litigations related to for example labor environment. Leasing sustainable office space could certainly decrease the risk of future employee litigation, for instance by providing high indoor air quality standards.

Furthermore, by anticipating future legislative changes, firms can avoid costly organizational and operational restructuring. With respect to real estate, property investors, or firms that own their corporate properties, could for instance incur costly renovations if environmental building standards would become very strict. By investing in more sustainable buildings, this future risk can be reduced.

\subsubsection{Ethical Behavior}

Corporate social engagement originally started based on ethical motives rather than financial gains (Bowen, 1953). However, to obtain critical mass and to convince the investment community, the focus of the CSR debate often shifts to the economic virtues of incorporating CSR in strategic decision-making. But, the first-movers and early adopters of CSR-driven innovations are often those parties for which monetary gains are of secondary importance. Federal and local governments and non-profit organizations are eager to show their environmental engagement through leasing space in green buildings. Just because this is 'the right thing to do' (Wood, 1991). Moreover, for these governmental and non-profit organizations, the possibly higher financial outlay is generally imposed on the general public through taxations and donations, which might blur rational economic decisionmaking.

\subsubsection{Propositions}

The four underlying drivers of CSR-based real estate decision-making can each be related to individual industries. Therefore, we formulate testable propositions that are empirically addressed in the next section, using a dataset with detailed information on corporate tenants in green office buildings in U.S

Proposition l: Firms in the tertiary sector, i.e. the service industry, profit most from the cost savings and the improved indoor air quality of green office buildings. Therefore, they will have a higher likelihood of renting green office space.

Proposition Ila: Firms that are dependent on the public capital market are more likely to lease office space in green buildings, as this might improve reputation and thus lower the cost of public capital.

Proposition $/ \mathrm{lb}$ : As stakeholder pressure regarding CSR is mainly directed at the largest and most visible firms in an industry, these are more likely to act in a social and environmentally responsible manner and therefore have a higher likelihood to lease green office space.

Proposition $/ / c$ : Firms with environmentally sensitive operations will be more likely to leasing green office space, as this can help to offset their negative corporate image. 
Proposition Ild: Firms in industries that are dependent on human capital and that are labor-intensive, are more likely to rent office space in green buildings, which provide superior working conditions.

Proposition III: Government, government-related organizations and non-profit institutions are more likely to act in socially responsible ways, and thus to lease green space, as monetary gains are of secondary importance. The possibly higher cost of leasing green space can be easily passed on to the beneficiary or taxpayer.

\subsection{Data}

We focus on tenants in commercial office buildings that have received an Energy Star or LEED certification. These green labels represent the most widely used certifications of buildings sustainability in the United States. The Energy Star label is a joint initiative of the U.S. Environmental Protection Agency and the U.S. Department of Energy. Whereas Energy Star initially started of as a measure of energy efficiency for computers and home appliances, the label was later extended to include residential as well as non-residential real estate. The energy performance and emissions of commercial and industrial facilities are scored on a 1 to 100 scale, where energy use is objectively assessed by an independent engineer. Those buildings that achieve a score of 75 or higher are eligible for an Energy Star certification, indicating that they are among the top 25 percent of buildings in the country for energy performance. As of June 2008, there were 4,724 buildings with an Energy Star label, of which 1,784 were office buildings.

The Leadership in Energy and Environmental Design (LEED) is a third party certification program, initiated in 2000 by the U.S. Green Building Council (USGBC), a non-profit organization. There are separate programs for existing buildings and newly developed buildings. Certification is based on a point-based system; the landlord has to score performance of a building for six LEED credit categories, and projects must satisfy particular prerequisites to earn points. The six categories include sustainable sites, water efficiency, energy and atmosphere, materials and resources, indoor environmental quality and innovation in design. A LEED certificate is awarded based on the aggregate score, where the level of the award can range from bronze (good) to platinum (excellent). As of June 2008, approximately 1,400 buildings had been awarded a LEED certificate.

We retrieve data on existing office buildings with an Energy Star and/or a LEED label by matching the location characteristics of Energy Star and LEED buildings that are provided on the respective websites with the CoStar database. CoStar is one of the major U.S. providers of commercial real estate data, and records all commercial property transactions, building characteristics, rental data, and whether buildings have been awarded a green certificate. This leads to a sample of 1,360 office buildings with a green label, of which 1,045 buildings with an Energy Star certification, 286 buildings with a LEED certification, and 29 buildings with both certifications.

\subsubsection{Tenant Sample}

For each green building in the sample, we retrieve the names of the largest tenants - up to a maximum of five, their Standard Industry Classification (SIC) code and floor space occupied, all from the CoStar Tenant module. In addition, this Tenant module allows us to collect data on the total square footage of office space occupied by each individual firm. Similarly, we collect data on the total square footage of office space that is occupied in each 
Corporate Governance and Sustainability in Global Property Markets

specific 4-digit SIC code. The totals of office space occupied by individual tenants or industry groups might be slightly underestimated, as CoStar covers approximately $80 \%$ of the U.S. commercial property market. Moreover, tenant data is not available for all green office buildings. This leads to a sample of 1,180 green office buildings, occupied by a total of 3,179 unique tenants.

Table 6.1 provides an overview of the green space occupied by the twenty largest tenants. Column (1) shows the aggregate of square footage of green space occupied. Commercial banks, such as Wells Fargo Bank، Bank of America and ABN AMRO are all among the top-tenants of green space. This can be partially explained by the extensive use of office space, i.e. the space-intensity of the banking industry, which is in line with Proposition 1 , in which we hypothesize that firms in the tertiary sector are more likely to rent green space. Furthermore, in support of Proposition III, federal government and government-related organizations such as the Department of Health and Human Sciences and the Environmental Protection Agency are prominent tenants of green office space, the latter thereby putting preach to practice. Last, the oil industry seems to be well represented in green office buildings, with tenants such as Shell and Chevron leasing a substantial percentage of the green buildings office stock. This is in line with Proposition lla. 
Table 6.1

Incidence of Green Space Utilization by Major Tenants

Fraction of Firm's Office Space Housed in Green Buildings

\begin{tabular}{|c|c|c|c|c|c|c|}
\hline & \multicolumn{5}{|c|}{ Space Occupied } \\
\hline & & (1) & (2) & (3) & (4) & (5) \\
\hline \multirow{6}{*}{ Tenant Name } & \multirow{6}{*}{ Industry Description } & Green & Fraction & Cum. Fraction & Total & Green \\
\hline & & Office & of Total & of Total & Space & as Fraction \\
\hline & & Space & Green & Green & CoStar & of Total \\
\hline & & & Space & Space & & Space \\
\hline & & & & & & CoStar \\
\hline & & $\times 1000$ sq. ft. & $\%$ & $\%$ & $\times 1000$ sq. ft. & $\%$ \\
\hline Wells Fargo Bank & National Commercial Banks & 2,741 & $1.61 \%$ & $1.61 \%$ & 7,343 & $37.33 \%$ \\
\hline United States Government & General Government & 2,415 & $1.42 \%$ & $3.03 \%$ & 14,631 & $16.50 \%$ \\
\hline Bank of America & National Commercial Banks & 2,124 & $1.25 \%$ & $4.28 \%$ & 18,695 & $11.36 \%$ \\
\hline ABN AMRO & State Commercial Banks & 1,724 & $1.01 \%$ & $5.29 \%$ & 2,993 & $57.60 \%$ \\
\hline State of California & General Government, NEC & 1,568 & $0.92 \%$ & $6.21 \%$ & 5,706 & $27.49 \%$ \\
\hline Deloitte \& Touche & $\begin{array}{l}\text { Accounting, Auditing, } \\
\text { Bookkeeping }\end{array}$ & 1,554 & $0.91 \%$ & $7.13 \%$ & 5,131 & $30.28 \%$ \\
\hline Best Buy & $\begin{array}{l}\text { Radio, Television, } \\
\text { Consumer Electronics }\end{array}$ & 1,500 & $0.88 \%$ & $8.01 \%$ & 2,104 & $71.31 \%$ \\
\hline U.S. Dept. of Health & General Government & 1,442 & $0.85 \%$ & $8.86 \%$ & 1,662 & $86.72 \%$ \\
\hline \& Human Sc. & & & & & & \\
\hline Shell & Gasoline Service Stations & 1,362 & $0.80 \%$ & $9.66 \%$ & 3,989 & $34.14 \%$ \\
\hline Chevron & Gasoline Service Stations & 1.229 & $0.72 \%$ & $10.38 \%$ & 6,181 & $19.88 \%$ \\
\hline Blue Cross \& Blue Shield & Hospital and Medical Service Plans & 1,211 & $0.71 \%$ & $11.09 \%$ & 12,251 & $9.89 \%$ \\
\hline Adobe Systems & Prepackaged Software & 1,158 & $0.68 \%$ & $11.77 \%$ & 1,388 & $83.43 \%$ \\
\hline Compuware Corporation & Prepackaged Software & 1,094 & $0.64 \%$ & $12.41 \%$ & 1,300 & $84.18 \%$ \\
\hline American Express & Personal Credit institutions & 1,018 & $0.60 \%$ & $13.01 \%$ & 6,754 & $15.07 \%$ \\
\hline The Vanguard Group & Investment Advice & 990 & $0.58 \%$ & $13.59 \%$ & 1,569 & $63.07 \%$ \\
\hline $\mathrm{Cal} / \mathrm{EPA}$ & $\begin{array}{l}\text { Land, Mineral, Wildlife, } \\
\text { Forest Conservation }\end{array}$ & 950 & $0.56 \%$ & $14.15 \%$ & 950 & $100.00 \%$ \\
\hline Mitre Corporation & $\begin{array}{l}\text { Commercial Physical and } \\
\text { Biological Research }\end{array}$ & 944 & $0.55 \%$ & $14.71 \%$ & 1,293 & $73.02 \%$ \\
\hline JP Morgan Chase & Investment Advice & 907 & $0.53 \%$ & $15.24 \%$ & 10,670 & $8.50 \%$ \\
\hline Skadden & Legal Services & 889 & $0.52 \%$ & $15.76 \%$ & 1,751 & $50.77 \%$ \\
\hline Ernst \& Young & Accounting, Auditing, Bookkeeping & 864 & $0.51 \%$ & $16.27 \%$ & 4,149 & $20.83 \%$ \\
\hline
\end{tabular}

Notes: Table 6.1 shows the 20 corporate tenants that are the largest occupiers of green office space, where green office space is defined as commercial office buildings with an Energy Star and/or LEED rating. Total square footage of office space occupied by each tenant is collected from the CoStar Tenant Module. Figures in Columns (4) and (5) might be underestimated, as CoStar covers approximately 80 percent of the U.S. commercial office market. 
To account for differences in office space utilization between industries, column (4) shows the total square footage of office space occupied by the largest green tenants and column (5) presents the fraction of green office stock relative to the total office stock. Several trends emerge. First, the California Environmental Protection Agency $(\mathrm{Cal} / \mathrm{EPA})$ is not only among the top-20 occupants of green office space, but its total office stock has a green label. Indeed, as the company reports, the headquarter building in Sacramento, California, is equipped with state-of-the-art techniques to improve indoor air quality and to reduce energy use. It is among the world's most energy and resource-efficient buildings. Thereby, the building "gives a physical presence to the reality of a single agency whose task is to guard the great environment." This is an example of how non-profit or governmental organizations derive non-financial utility from leasing green, and can lead the way in sustainable property investments, supporting Proposition III. As mentioned on the Cal/EPA website, "this approach not only makes environmental sense, but it also makes the building a better place to visit and in which to work."

Some of the commercial banks are not only prominent tenants of green space in absolute terms, but also relative to their total office stock. For example, ABN AMRO and Wells Fargo lease substantial proportions of their office stock - 58 percent and 37 percent, respectively - in green buildings. For the former, the headquarters in Chicago provide the main explanation: the $1.3 \mathrm{~m} I \mathrm{n}$ square foot office building, which makes up most of the office stock leased by ABN AMRO, has been awarded a 'LEED for new construction' label at the gold level in 2007. Wells Fargo occupies several buildings with a green label. In fact, sustainability is a major strategic issue, and the bank has a well-defined sustainability policy. In interviews conducted by telephone by the authors, a representative explained that "... it is important to really show our environmental focus, for example by leasing green office space." As argued by Ramus and Montiel (2005), it is the implementation of CSR policies rather than the policy commitment that is necessary to reap the business benefits. This is in line with reputation proposition llb, as leasing space in a green building may send a signal of social awareness to stakeholders.

For other corporations, such as Adobe Systems, Compuware Corp., or The Vanguard Group, leasing green space is not a deliberate act, but merely comes with a preference for high quality office space, in combination with a growing need for space due to rapid expansion. Indeed, it has been shown that green buildings are in general younger, have a higher quality rating, and have more amenities in comparison to regular office buildings (Eichholtz, et al. 2008b).

Table 6.2 presents the aggregate of green office space per four-digit SIC code, in absolute terms as well as relative to the total office stock per SIC code. Column (1) shows the top-20 of industry categories with the highest aggregate of total green office space. Legal services - which includes attorneys, counselors at law, law offices, lawyers, legal aid services and other legal services - is by far the largest occupant of green office space. This contrasts the results in Table 6.1, where only one single tenant from the Legal Services industry made the top-20. So, although individually tenants from the legal services industry are not major occupiers of green space, on the aggregate the sector seems to have a preference for sustainable office buildings. Intuitively, this is in line with propositions I and Ild, wherein we argue that tenants in the tertiary sector are more likely to lease space in green buildings, as direct benefits of leasing green space affect these tenants most, and superior labor environment positively affects the human capital employed. 
Table 6.2

Incidence of Green Space Utilization by Industry

Fraction of Office Space Housed in Green Buildings by Four-Digit SIC

\begin{tabular}{|c|c|c|c|c|c|c|}
\hline & & \multicolumn{5}{|c|}{ Space Occupied } \\
\hline & & (1) & (2) & (3) & (4) & (5) \\
\hline & & Green & Fraction & Cumulative & Total & Green \\
\hline \multirow[t]{5}{*}{ SIC Code } & Industry Description & Office & of Total & Fraction & Office & as Fraction \\
\hline & & Space & Green & of Total & Space & of Total \\
\hline & & & Space & Green & CoStar & Space \\
\hline & & & & Space & & CoStar \\
\hline & & $\times 1000 \mathrm{sq} . \mathrm{ft}$ & $\%$ & $\%$ & $\times 1000$ sq. ft. & $\%$ \\
\hline 8111 & Legal Services & 25,593 & $15.04 \%$ & $15.04 \%$ & 217,097 & $11.79 \%$ \\
\hline 6021 & National Commercial Banks & 9,436 & $5.55 \%$ & $20.59 \%$ & 86,782 & $10.87 \%$ \\
\hline 9199 & Executive, Legislative and General Office & 9,035 & $5.31 \%$ & $25.90 \%$ & 67,081 & $13.47 \%$ \\
\hline 1311 & Crude Petroleum and Gas & 7,076 & $4.16 \%$ & $30.06 \%$ & 11,304 & $62.60 \%$ \\
\hline 6282 & Investment Advice & 6,532 & $3.84 \%$ & $33.90 \%$ & 100,939 & $6.47 \%$ \\
\hline 8721 & Accounting, Auditing, and Bookkeeping Services & 5,158 & $3.03 \%$ & $36.93 \%$ & 136,766 & $3.77 \%$ \\
\hline 5731 & Radio, Television, and Consumer Electronics Stores & 1,531 & $0.90 \%$ & $37.83 \%$ & 3,888 & $39.37 \%$ \\
\hline 9311 & Public Finance, Taxation, and Monetary Policy & 822 & $0.48 \%$ & $38.31 \%$ & 14,491 & $5.67 \%$ \\
\hline 7373 & Computer Integrated Systems Design & 816 & $0.48 \%$ & $38.79 \%$ & 19,487 & $4.19 \%$ \\
\hline 3812 & Search, Detection, Navigation, Guidance, ... & 291 & $0.17 \%$ & $38.96 \%$ & 4,869 & $5.97 \%$ \\
\hline 2759 & Commercial Printing, NEC & 287 & $0.17 \%$ & $39.13 \%$ & 3,996 & $7.17 \%$ \\
\hline 3069 & Fabricated Rubber Products, NEC & 285 & $0.17 \%$ & $39.30 \%$ & 769 & $37.08 \%$ \\
\hline 4731 & Arrangement Transportation of Freight and Cargo & 282 & $0.17 \%$ & $39.46 \%$ & 8,348 & $3.38 \%$ \\
\hline 9621 & Regulations and Adm. of Transportation Programs & 280 & $0.16 \%$ & $39.63 \%$ & 9,115 & $3.07 \%$ \\
\hline 7997 & Membership Sports and Recreation Clubs & 274 & $0.16 \%$ & $39.79 \%$ & 1,696 & $16.15 \%$ \\
\hline 8641 & Civic, Social, and Fraternal Associations & 274 & $0.16 \%$ & $39.95 \%$ & 14,362 & $1.91 \%$ \\
\hline 2086 & Bottled and Canned Soft Drinks, Carbonated Waters & 261 & $0.15 \%$ & $40.10 \%$ & 5,037 & $5.19 \%$ \\
\hline 5411 & Grocery Stores & 253 & $0.15 \%$ & $40.25 \%$ & 8,363 & $3.03 \%$ \\
\hline 4724 & Travel Agencies & 252 & $0.15 \%$ & $40.40 \%$ & 7,539 & $3.34 \%$ \\
\hline 6552 & Land Subdividers and Developers, & 250 & $0.15 \%$ & $40.55 \%$ & 9,676 & $2.58 \%$ \\
\hline
\end{tabular}

Notes: Table 6.2 shows the 20 industry groups that are the largest occupiers of green office space, where green office space is defined as commercial office buildings with an Energy Star and/or LEED rating. Industry groups are defined by the Standard Industry Classification (SIC) codes. Total square footage of office space occupied by each industry group is collected from the CoStar Tenant Module. Figures in Columns (4) and (5) might be underestimated, as CoStar covers approximately 80 percent of the U.S. commercial office market.

Other industry categories that are among the largest tenants of green space are Executive, Legislative and General Office (public administration), National Commercial Banks, Crude Petroleum and Gas, and Investment Advice. This is generally in line with the evidence in Table 6.1.

However, in Column (5), where we document the incidence of green space as a percentage of total office space (as reported in CoStar), we observe that a notable 63 percent of the total office stock of the Crude Petroleum 
and Gas industry is leased in office buildings with a green label. This fraction is by far higher than for other industries, and supports our proposition $\| c$ : firms in environmentally sensitive industries have a higher likelihood of leasing green. For example, Chevron Corp. has recently occupied a newly developed building in Louisiana, which has been awarded a LEED Gold certification. Leasing green space "supports the company's long-standing commitment to the Gulf Coast and the state of Louisiana. The building is located in a park-like setting, and the $0.3 \mathrm{mln}$ sq.ft. office building provides a safe, healthy and productive workplace for up to 750 people" ${ }^{38}$ Although this expression of social and environmental awareness is unrelated to the core business of Chevron, it might help to improve its reputation amongst stakeholders.

\subsubsection{Control Sample}

To empirically address the clustering of tenants in green buildings, we match each green office building with a set of control buildings, based on the longitude and latitude of the building. To this end, we select all existing non-green office buildings in a 0.25 mile radius, using geographic information system (GIS) techniques in the CoStar database. This leads to 1,180 unique clusters with on average three control buildings per cluster. For each control building, we collect information on the five major tenants, their SIC classification and their square footage occupied. In total, the control sample includes 3,861 office buildings, with approximately 8,000 unique tenants. Appendix 6.A provides an overview of the tenants and industries with the largest aggregate office stock.

\subsection{Analysis and Empirical Results}

\subsubsection{Methods}

We hypothesize in Section 6.2 that particular industries may have a higher likelihood of leasing green office space, for example governmental and non-profit organizations - to maximize non-financial utility - or the oil industry - to offset negative reputation effects from environmentally sensitive operations. To empirically test the propositions, we first calculate the fraction of leased office space per building for each tenant. Then, we aggregate these fractions based on one-digit SIC codes for each green building and each control building. We exploit one-digit SIC codes rather than four-digit SIC codes, as the latter would not add up to a sufficient number of observations per industry. ${ }^{39}$ This results in a cross-section of fractions of office space per one-digit SIC per building, matched with building characteristics, including the presence of an Energy Star and/or LEED certification, building age, size, quality, etc.

We repeat the following equation for each one-digit SIC code $s$

$\log 0_{i n}=a+\beta_{i} X_{i}+\sum_{n=1}^{N} \gamma_{n} c_{n}+\delta g_{i}+\varepsilon_{i n}$

where the dependent variable is the logarithm of the total square footage 0 occupied by tenants with SIC code $s$

38 Chevron press release, May 2008.

39 Following the standard industry classification division structure, we group industries in 1/ Manufacturing, 2) Transportation, Communications, Electric, Gas, and Sanitary Services, 3) Wholesale and Retail Trade, 4) Finance, Insurance and Real Estate, 5) Services and 6) Public Administration. We leave out Agriculture, Forestry and Fishing, as well as Mining and Construction, as we do not have sufficient observations to come to a meaningful analysis. 
as a percentage of the total rentable building are (RBA) in commercial office building $i$ in cluster $n$. $X$, is a vector of the hedonic characteristics of building $i$, such as building age, presence of amenities, etc. $c_{n}$ is a dummy variable with a value of 1 if building $i$ is located in cluster $n$ and zero otherwise. These location coefficients can individually affect the percentage of square foot occupied, to account for locational effects. We include dummy one for each of the $N$ distinct 0.2 -square-mile clusters. $g_{i}$ is a dummy variable with a value of 1 if building $i$ is rated by Energy Star or USGBC and zero otherwise. $\alpha, \beta_{\mathrm{i}^{\prime}} \gamma_{n}$ and $\delta$ are estimated coefficients and $\varepsilon_{n}$ is an error term. We estimate the equation in a Tobit setup.

\subsubsection{Results}

Table 6.3 presents the results of the Tobit estimation of Equation (1), with the number of each column corresponding with a specific industry group (definition in table notes). The dependent variable represents the fraction of office space occupied by tenants in the corresponding industry group. The coefficients have no straightforward economic interpretation, but the interest is rather in the sign and significance of the coefficients.

Column (1) shows the results for the manufacturing industry, which includes everything ranging from apparel producers to car manufacturers. Office utilization is expected to be rather limited for these sectors. Indeed, the main explanatory variables are inconclusive, and our green dummy has no significant effect. The same holds for the transportation and communications industry, for which results are documented in column (2). Although there seems to be a preference for high quality and large buildings, office space with a green label is not particularly favored.

Office space leased by retail and wholesale trade is mainly in small buildings with a relatively low quality. As green buildings are in general new and large buildings, the negative green coefficient is line with expectations. Moreover, we note that for retail and wholesale trade, it would be more interesting to examine the extent to which the actual retail space has been awarded a green certificate, rather than the office buildings that back up their operations.

Columns (4) and (5) show results for the finance, insurance and real estate industry, and the services industry, respectively. Especially for these industries, which include legal services and commercial banking, one would expect that leasing space in green office buildings is rational, as energy efficiency (Proposition I) and indoor air quality (Propositions I and III) are of major importance. However, contrasting these expectations, we document a negative coefficient for both estimations. So, although descriptive evidence in Section 6.3 indicated that some firms in the finance and service industry are among the larger tenants of green space, a general trend towards leasing green cannot yet be documented in these industries. This is but one indication that it are the larger and most visible firms that move first in the implementation of social and environmental measures, only followed later by the critical mass (Proposition Ilb).

Finally, in line with Proposition III, tenants in public administration have a preference for green office space, indicated by the positive and significant coefficient for the green dummy in Column (5). These results indicate that critical mass has been achieved in the occupancy of green space by government-related tenants, while controlling for the occupancy of regular office space. Furthermore, high quality office space - Class A - increases the likelihood of governmental office demand. 
Table 6.3

Regression Results Industry Buildings Preference

(Dependent Variable: Fraction of Office Space Occupied by SIC code per Building)

\begin{tabular}{|c|c|c|c|c|c|c|}
\hline & (1) & (2) & (3) & (4) & (5) & (6) \\
\hline \multirow[t]{2}{*}{ Green Rating (1 = yes) } & 0.030 & -4.134 & -0.075 & -0.478 & -0.178 & 0.730 \\
\hline & {$[0.028]$} & {$[0.000]$} & {$[0.028]^{* * *}$} & {$[0.026]^{* * *}$} & {$[0.019]^{* * *}$} & {$[0.030]^{* * *}$} \\
\hline \multicolumn{7}{|l|}{ Building Class } \\
\hline \multirow[t]{2}{*}{ Class A $(1=$ yes $)$} & 0,000 & 0.135 & -0.125 & 0.041 & -0.028 & 0.105 \\
\hline & {$[0.041]$} & {$[0.061]^{* *}$} & {$[0.034]^{* * *}$} & {$[0.029]$} & {$[0.027]$} & {$[0.050]^{* *}$} \\
\hline \multirow[t]{2}{*}{ Class B $(1=$ yes $)$} & -0.024 & 0.109 & -0.059 & 0.029 & -0.043 & 0.108 \\
\hline & {$[0.031]$} & {$[0.043]^{* *}$} & {$[0.023]^{* * *}$} & {$[0.021]$} & {$[0.020]^{* *}$} & {$[0.040]^{* * *}$} \\
\hline \multirow[t]{2}{*}{ Fraction Occupied } & -0.012 & 0.083 & 0.106 & 0.055 & 0.251 & 0.031 \\
\hline & {$[0.076]$} & {$[0.106]$} & {$[0.060]^{*}$} & {$[0.052]$} & {$[0.051]^{* * *}$} & {$[0.088]$} \\
\hline \multicolumn{7}{|l|}{ Stories } \\
\hline \multirow[t]{2}{*}{ High $($ yes $=1)$} & 0.034 & -0.085 & -0.152 & 0.013 & -0.029 & 0.069 \\
\hline & {$[0.042]$} & [0.059] & {$[0.037]^{* * *}$} & {$[0.029]$} & {$[0.028]$} & {$[0.048]$} \\
\hline \multirow[t]{2}{*}{ Intermediate (yes $=1$ ) } & 0.018 & -0.006 & -0.095 & -0.010 & -0.042 & -0.029 \\
\hline & {$[0.029][$} & $0.040]$ & {$[0.024]^{* * *}$} & {$[0.021]$} & {$[0.019]^{* *}$} & {$[0.034]$} \\
\hline \multicolumn{7}{|l|}{ Age } \\
\hline \multirow[t]{2}{*}{$<10$ years } & 0.016 & 0.014 & 0.065 & 0.020 & 0.071 & 0.049 \\
\hline & {$[0.049]$} & [0.083] & {$[0.045]$} & {$[0.038]$} & {$[0.035]^{* *}$} & {$[0.057]$} \\
\hline \multirow[t]{2}{*}{$10-20$ years } & 0.026 & -0.083 & -0.051 & 0.007 & 0.009 & 0.071 \\
\hline & {$[0.046]$} & {$[0.079]$} & [0.043] & {$[0.034]$} & {$[0.031]$} & {$[0.052]$} \\
\hline \multirow[t]{2}{*}{$20-30$ years } & -0.052 & -0.014 & -0.012 & 0.005 & 0.020 & 0.092 \\
\hline & {$[0.036]$} & [0.049] & {$[0.030]$} & {$[0.025]$} & {$[0.024]$} & {$[0.041]^{* *}$} \\
\hline \multirow[t]{2}{*}{$30-40$ years } & -0.051 & -0.005 & -0.008 & 0.033 & -0.013 & 0.012 \\
\hline & {$[0.038]$} & {$[0.051]$} & [0.032] & {$[0.026]$} & [0.025] & {$[0.043]$} \\
\hline \multirow[t]{2}{*}{ Renovated (1 = yes) } & 0.024 & -0.060 & -0.013 & -0.061 & 0.016 & 0.049 \\
\hline & {$[0.025]$} & {$[0.033]^{*}$} & {$[0.020]$} & {$[0.017]^{* * *}$} & {$[0.016]$} & {$[0,030]^{*}$} \\
\hline \multirow{2}{*}{$\begin{array}{l}\text { Building Size } \\
\text { (millions of sq.ft.) }\end{array}$} & 0.038 & 0.161 & -0.180 & 0.077 & -0.030 & -0.194 \\
\hline & [0.052] & {$[0.073]^{* *}$} & {$[0.056]^{* * *}$} & {$[0.038]^{* *}$} & {$[0.038]$} & {$[0.067]^{* * *}$} \\
\hline \multirow[t]{2}{*}{ Constant } & -0.424 & -0.804 & -0.525 & -0.220 & -0.315 & -0.896 \\
\hline & {$[0.099]^{* * *}$} & {$[0.244]^{* * *}$} & {$[0.095]^{* * *}$} & {$[0.083]^{* * *}$} & {$[0.075]^{* * *}$} & ${ }^{*}[0.110]^{* * *}$ \\
\hline Sample Size & 10462.00 & 10462.00 & 10462.00 & 10462.00 & 10462.00 & 10462.00 \\
\hline $\mathrm{X}^{2}$ & 1340.17 & 1123.84 & 1363.73 & 1482.93 & 1070.80 & 2104.36 \\
\hline Pseudo $R^{2}$ & 0.26 & 0.29 & 0.20 & 0.16 & 0.08 & 0.28 \\
\hline
\end{tabular}

Notes:

Columns correspond with:

(1) Manufacturing

(2) Transportation, communications, electric, gas, and sanitary services

(3) Retail and wholesale trade

(4) Finance, insurance, and real estate

(5) Services

(6) Public administration

Standard errors in brackets. Significance at the 0.10, 0.05 and 0.01 levels is indicated by ${ }^{*},{ }^{* *}$ and ${ }^{* * *}$ respectively. 


\subsection{Conclusions}

Awareness is growing that the build environment is important in the current debate on global warming, both as a source of emissions and as a major consumer of energy and raw materials. Firms engaged in corporate social responsibility - either actively or passively - should therefore include real estate in their strategic decision making, for example by leasing green office space.

Prior evidence has shown that some corporate tenants are not only willing to lease space in green office buildings, but that these tenants pay a rental premium as well (Eichholtz, et al. 2008b). Based on the CSR literature, we formulate four drivers of CSR adoptiveness in real estate decision-making. Then, we formulate propositions as to which firms or industries are willing to rent green space and to pay the rental premium. Using a comprehensive dataset on the tenants in U.S. office buildings with a green label - awarded by Energy Star or USGBC - we empirically address these propositions.

The descriptive results show that the oil industry is a major occupier of green office space, which is in line with the proposition that firms in environmentally sensitive industries, will deliberately incorporate sustainability in strategic decisions such as headquarter selection, in order to enhance reputation. Firms in the legal and financial services industry lease a substantial share of green office space as well. For some of these firms, further investigation shows support for our proposition that firms in the tertiary sector acknowledge the productivity benefits of green buildings. However, for other firms, leasing green is a result of the preference for high quality buildings, rather than an act of responsible behavior.

In general, the descriptive evidence confirms our propositions to the extent that the expected industries each have a few 'green' leaders. However, the results of the Tobit-analyses are clear: only in public administration there is a critical mass of green tenants. The government and government-related organizations, for which non-financial utility is of major importance, are significantly more likely to rent green office space as compared to regular office space. Most prominent example is California's Environmental Protection Agency, with all of its activities located in a highly sophisticated environmental-friendly office building.

For developers and investors, this has important implications. The higher initial outlay that may be needed for a newly developed sustainable office building, or for the refurbishment of an existing office building, can be recouped through energy savings and lower risk premiums, or through higher net rents. Currently, industry leaders and non-profit organizations (i.e. government) seem to be most willing to pay this rental premium. However, for the critical mass to engage in renting green, a better insight in direct and indirect benefits might be needed first.

This study is first attempt to address the relationship between corporate social responsibility and corporate real estate decisions. Analyst screening of corporate ESG practices is no longer confined to operational activities, it also extends to the environmental sustainability of corporate real estate (especially headquarters). However, our information on the tenants in green buildings is limited: we have data on industry classification only. Therefore, we are not able to test Proposition 2.a. More specific information on tenants, for example regarding financial fundamentals, credit rating or innovativeness, may help to better understand the strategic decision-making of tenants in green buildings. 
Corporate Governance and Sustainability in Global Property Markets

Appendix 6.A

Incidence of Green Space Utilization by Major Tenants

Incidence of Green Space Utilization by Major 4-digit SIC code

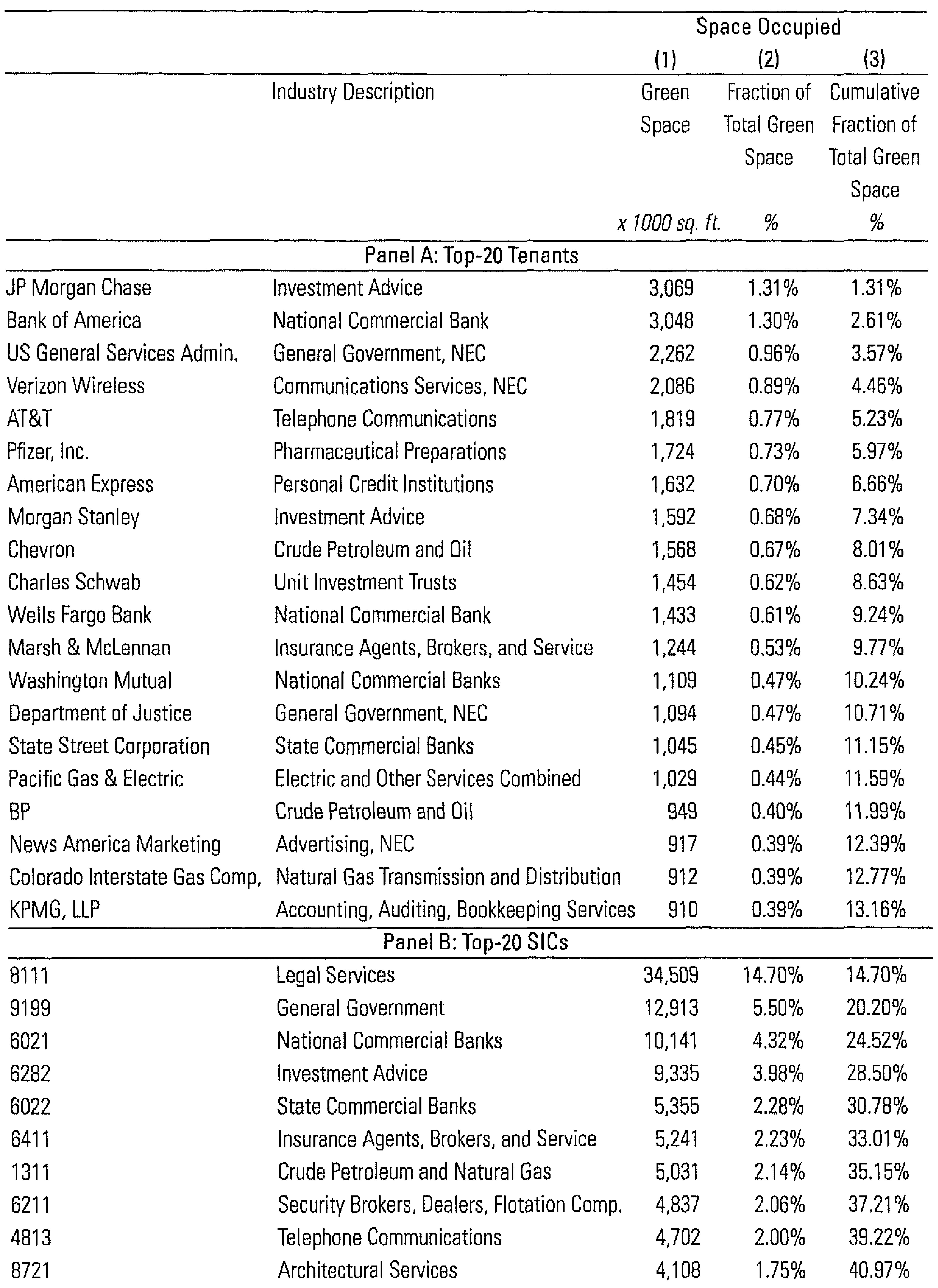


Appendix 6.A (continued)

\begin{tabular}{lllll}
8742 & Management Consulting Services & 3,663 & $1.56 \%$ & $42.53 \%$ \\
2834 & Pharmaceutical Preparations & 3,492 & $1.49 \%$ & $44.01 \%$ \\
8221 & Colleges, Universities, Professional Schools & 3,252 & $1.39 \%$ & $45.40 \%$ \\
8399 & Social Services, NEC & 2,849 & $1.21 \%$ & $46.61 \%$ \\
4911 & Electric Services & 2,846 & $1.21 \%$ & $47.83 \%$ \\
7389 & Business Services, NEC & 2,752 & $1.17 \%$ & $49.00 \%$ \\
4899 & Communications Services, NEC & 2,544 & $1.08 \%$ & $50.08 \%$ \\
6531 & Real Estate Agents and Managers & 2,541 & $1.08 \%$ & $51.16 \%$ \\
8711 & Engineering Services & 2,402 & $1.02 \%$ & $52.19 \%$ \\
8748 & Business Consulting Services, NEC & 2,188 & $0.93 \%$ & $53.12 \%$ \\
\hline
\end{tabular}









\section{Summary, Practical}

Implications and Further Research 


\section{Summary, Practical Implications and Further Research}

\subsection{Summary of Findings and Practical Implications}

Over the past decades, the role of real estate in the institutional investment portfolio has changed from alternative asset class to mainstream investment. Often, real estate is now referred to as the third asset class, besides stocks and bonds. The recent turmoil in the financial markets has all but increased the importance of asset classes other than equities. However, with the institutionalization of the real estate sector and the rise of indirect property investments, the global property sector has become more vulnerable to a conflict of interest between shareholders of property companies and the executives therein. In addition, an increasing number of countries have introduced the REIT-structure, which is characterized by distinctively different legal and operational restrictions throughout the world. The combination of these developments yields the need for a better understanding of corporate governance practices in the listed property sector. This dissertation provides insight in the functioning and effectiveness of corporate governance mechanisms in the global listed property sector.

Other elements of corporate social responsibility, such as environmental sustainability and social policies, have only recently started to receive the attention of real estate investors and managers. Corporate engagement of institutional investors generally focused on mainstream equity investments hitherto. However, analyst and investor screening of corporate environmental and social policies is slowly descending on other asset classes, including real estate investments. Thus far, stakeholders are struggling as to how far they should go in the implementation of corporate social responsibility measures in the property sector, mainly because the financial implications of these measures are unclear. This dissertation aims to fill the research gap on environmental sustainability in the property sector, by providing the first evidence on the economics of 'green' office buildings, and of the behavior of corporate tenants therein.

In this concluding chapter, we provide a short summary of the five empirical chapters in this dissertation. Each summary is be followed by a discussion on the practical implications of the academic findings. The chapter ends with suggestions for future research.

In Part One of this dissertation, we start with a chapter on the functioning of the market for corporate control in the listed property sector. The documented lack of hostile takeovers for the real estate sector leads to the question whether the market for corporate control functions effectively. Using an international sample of real estate takeovers, we find that poor firm performance of property companies is a predominant motive for 
takeovers. This confirms the inefficient management hypothesis and thereby adds new evidence to the existing real estate finance literature. The latter part of chapter 2 shows that the real estate takeover market does not only differ from other sectors with respect to hostile takeovers, but wealth effects surrounding takeovers are different as well.

Chapter 2 has three main implications. First, even though real estate takeovers are mostly friendly, mergers and acquisitions in the property sector seem to make financial sense for shareholders. Acquiring property companies are able to cherry pick targets by merging with underperforming counterparts, supporting the hypothesis that takeovers are a mechanism to discipline the management of inefficient companies. Moreover, the acquirers are generally large and financially sound property companies, and are therefore able to integrate the operations of the target property company. This is reflected in aggregate positive wealth effects following takeovers, at least in the short run.

Second, from a corporate governance point of view, the results show that external control through the takeover market is an effective addition to the internal governance structure, and, more importantly, that the REIT structure does not complicate this mechanism. This empirical evidence contrasts untested claims in the U.S. REIT literature that the REIT structure obstructs the disciplinary force of the takeover market (Campbell, et al. 2001. Campbell, et al. 2005).

Third, our findings shed a new light on hostile takeovers. Generally hailed as a stronger form of market control than friendly takeovers, we suggest that the absence of hostile takeovers is not necessarily a bad thing, and can be explained. First, hostile takeovers probably do not create more value than friendly takeovers, although the lack of hostile takeovers in the real estate sector does not allow for empirical testing of this hypothesis. Second, although the information asymmetry is less of a problem in hostile real estate takeovers, it will take considerable time to regain possible overpayments in the real estate sector, making it an unattractive alternative to friendly takeovers. Third, the REIT structure increases transparency, which is so beneficial to corporate governance that it makes the market for corporate control less important as a governance mechanism. However, our sample shows that hostile takeovers do not take place in real estate markets without the REIT structure either, which suggests that the operations of real estate companies, whether they have a REIT-status or not, are relatively transparent. This reduces the need for an active market for corporate control by means of hostile takeovers.

In chapter 3, we study executive compensation practices, a topic of heated societal debate. Hitherto, executive compensation in property companies has been examined for U.S. REITs only, and findings in this strand of literature are often attributed to the specifics of the REIT structure. We put prior findings in perspective by examining the determinants of executive compensation in property companies in the United Kingdom, which represents the second largest property market in the world, but which used to be without a REIT structure until January 2007. Our results are distinctively different from the existing REIT literature, especially regarding the influence of corporate governance on compensation practices. Moreover, we document that both absolute and relative measures of performance can explain the level of long-term executive compensation. Although executive compensation provides a direct link between shareholder wealth and executive wealth, we find that executive shareholdings provide a much more powerful incentive for executives to create shareholder wealth, which is reflected in our pay-performance sensitivity measure. 
The implications of this chapter are threefold. First, for investors in listed property companies, say on pay is important, as the results show that shareholders can at least partially influence the various components of executive compensation. Whether investors make the right choice in imposing long-term incentives rather than cash compensation, as the institutional investors in our study tend to do, cannot be inferred from this chapter. However, there appears to be a relation between performance and long-term compensation, thereby increasing the pay-performance sensitivity, whereas the relationship between cash compensation and performance is non-existent. Moreover, achieving higher risk-adjusted returns seems to be rewarded, as suggested by the compensation differences between property types.

Second, investors need to make sure that corporate management is co-invested in the property company, as this is the most simple and direct alignment of interest between those in control and those who own the company. The pay-performance sensitivity following from cash compensation as well as long-term incentives is negligible as compared to the effect of insiders' shareholdings. A word of caution: neither the real estate literature nor the general finance literature provides a consensus on the optimal insider stake (Han, 2006).

Third, from a corporate governance point of view, it is reassuring to notice that abuse of power is getting harder for those in control, as the results show that in a situation where the CEO is also Chairman of the Board, executive compensation tends to decrease rather than to go up. However, in line with literature and anecdotal evidence, we find that non-executive directors on the board might not be as powerful in supervising those in control as is generally expected. A more thorough examination of the extent to which non-executive directors are truly independent directors should be a venue for future research.

In the last chapter of Part One, the functioning and effectiveness of corporate governance mechanisms in U.S. REITs is unraveled. We propose two competing hypotheses: the substitution hypothesis argues that the restricted setting in which REIT managers operate reduces the agency conflict by curbing managerial freedom. This might substitute the need for alternative corporate governance mechanisms and raise industry-wide governance standards. On the other hand, the complement hypothesis states that the legal restrictions in RElTs might lead to managerial entrenchment, thereby increasing the need for strong firm-level monitoring mechanisms. We test these hypotheses by examining the relationship between corporate governance and performance for REITs. A positive relationship has been well-established for regular firms in the corporate finance literature. Using a comprehensive corporate governance index - the Corporate Governance Quotient of the RiskMetrics Group - we document for the REIT sample that our governance index is neither related to REIT value, as measured by Tobin's $\mathrm{Q}$, nor to any of the three operating measures of performance, ROA, ROE, and FFO growth. These results contrast the consensus in the existing literature and the empirical evidence that we document for the sample of 5,000 regular $\mathrm{C}$-corporations. Moreover, our findings are supported by the positive relationship documented for two control samples - companies with relatively high corporate real estate ratios (CRERs) and a sample that is constructed by selecting all REITs in the G-Index. However, when distinguishing high payout from low payout REITs, we find that governance does matter for cash-rich REITs. Our results corroborate with the hypothesis that corporate governance has less impact on firm performance in strongly regulated business environments, as documented by Durnev and Kim (2005) and Klapper and Love (2004). We therefore explain the weak relation between corporate governance and performance in REITs as a 'REIT effect'. 
The results documented in chapter 4 are important to better understand the interaction between the REIT structure and corporate governance mechanisms. It is often suggested in the real estate literature that the structure of REITs intensifies the principle - agent problem (Campbell, 2002, Campbell, et al. 2005, Ghosh and Sirmans, 2003b, Ghosh and Sirmans, 2005, Ghosh and Sirmans, 2006). However, we argue that operational restrictions under which REITs operate, such as the distribution obligation, rather strengthen the institutional setting. Under the substitute hypothesis, this setting would even allow for weaker firm-level governance mechanisms, but in fact our empirical results show that firm-level corporate governance in the listed property industry is of extremely high quality. Thus, for institutional investors that allocate capital to REITs, corporate governance seems to be less of a concern.

On a more general level, our results have policy implications with respect to design of optimal corporate governance structures. In most modern economies, there is a revolving discussion as to how far the government should go in restricting those in control, in order to reduce the principle - agent problem. Various countries have issued non-binding corporate governance codes, such as the 'Tabaksblat Code' in the Netherlands, the 'Cromme Code' in Germany and the 'Combined Code' in the United Kingdom. Issues at stake are for example executive remuneration, the use of anti-takeover provision, the structure of the Board of Directors, or auditing practices. However, the institutional infrastructure of REITs seems to solve part of the traditional agency problem: restricting the operational framework in which executives can operate by law limits the possibilities of executives to engage in value-destructing behavior. This does not automatically imply that governance mechanisms at the corporate level are weak - REITs rank amongst the top-performers in terms of governance. However, the strong legal setting solves at least part of the agency problem and automatically reduces the need for further government involvement in the design of the optimal corporate governance structure.

In Part Two, we provide evidence on the economics of green buildings. The existence of well-established green rating systerns - Energy Star of the Environmental Protection Agency and the Leadership in Environment and Energy Design (LEED) of the U.S. Green Building Council - in combination with the relative transparency of the U.S. property market, allows us to compile a comprehensive dataset, which we employ in chapters 5 and 6 . In chapter 5, we compare rents and transaction prices of green office buildings with regular - non-green - office buildings, controlling for location effects using GIS-techniques. The results clearly indicate the importance of a green label in affecting the market rents of comparable commercial space in close proximity. The results suggest that the otherwise commercial building with an environmental certification will rent for about two percent more per square foot; the difference in effective rent is estimated to be about six percent per square foot. The increment to the selling price may be as much as 16 percent. Moreover, green office space appears to be less risky, as occupancy rates are higher and less volatile.

Our results provide the first fundamental evidence on the economic value of sustainability in the real estate sector. These findings have implications for investors as well as policy makers. Our results can provide critical mass and speed to the green building movement. Investors generally seem to assume a conflict between greenness and the bottom line, but our results show the contrary. This means that institutional investors can simultaneously pursue doing well and doing good.

For property investors with a portfolio of existing properties, the sustainability of the portfolio should be a major concern. Although an investor has detailed insight in the financial fundaments of individual properties, he is usually not aware of the cross-sectional variability in the sustainability of his properties. However, this is important information, as we show that green buildings are able to obtain better rental rates as compared 
to less efficient, non-green buildings. The rental premium and lower risk in more sustainable office buildings will increase value in the existing property portfolio of the investor. Therefore, it might well be a profitable investment to retrofit an existing building in order to achieve future savings on utility costs. This dissertation does not reflect on the costs of the initial outlay, but provides investors with a yardstick as to measure the payoff from 'green' investments. Moreover, there is risk involved in simply neglecting the sustainable status of properties in a portfolio of existing buildings. For example, tenants in less sustainable office buildings might face higher future utility and service costs. If the share of these costs relative to the net rent increases, tenants will benefit from moving to a more sustainable building, even if this implies higher net rents. For investors in less sustainable buildings, this leads to higher vacancy rates, a shorter economic lifetime, and an increased the risk.

For policy makers, our results can be helpful in obtaining critical mass for green property development. This is of major importance, as the construction of real estate alone is responsible for thirty percent of global $\mathrm{CO}_{2}$ emissions, which implies that more sustainable building in terms of land use, choice of raw materials and implementation of energy saving attributes, can lead to a substantial reduction of $\mathrm{CO}_{2}$ emissions. In convincing property developers and investors to engage in more sustainable building practices, a more structural approach towards the implementation of green rating systems might be helpful. Our U.S. study shows that the economic effects of two separate green label systems can be totally different. Currently, numerous sustainable building rating initiatives are appearing in property markets throughout the world, both initiated by local authorities and Inon-)profit organizations. This leads to a fragmentation of the market, which is fully contrasting the increased internationalization of both direct and indirect property investors. For an institutional investor, a major obstacle to green property investments could be the lack of a single transparent green label that is implemented throughout a region. Our results could help finding the right design of such a uniform label.

In chapter 6, we extend the initial dataset on green buildings by collecting data on the five largest tenants in each green building and their regular comparables. We argue that there are four main drivers why firms adopt the leasing of green office space. First, and most important, there is a direct bottom-line effect of leasing space in green buildings, following lower utility costs and service charges and higher employee productivity. Second, indirect benefits might arise from reputation effects, which in itself are driven by the main stakeholders. Third, risk arising from legislation is a forcing actor in the adoption process of green space. Fourth, for governments and non-profit organizations CSR-based decisions-making leads to non-financial utility, and leasing green space might therefore be part of the corporate strategy.

Based on the four drivers, we formulate testable hypotheses as to which industries might be most likely to lease green space. Using a dataset of 5,000 buildings - 1,200 of them having a green label - and 11,000 unique tenants - of which 3,200 tenants lease space in green buildings - we find that the industry leaders in the tertiary sector are amongst the major occupiers of green space. Moreover, tenants in the oil industry lease the majority of their office space in green buildings, supporting the proposition that firms with environmentally sensitive operations engage in reputation-enhancement through for example buildings choice. However, the empirical analysis shows that only government and non-profit organizations have a significantly higher likelihood of leasing green office space. This could be explained by the importance of non-financial utility over financial utility in these organizations, or simply more ethical behavior. 
The results in chapter 6 provide insights how the behavior of corporate tenants is affected by corporate social responsibility. Investors in sustainable office space should be aware that leasing decisions of firms in most industries are not yet driven by social and environmental considerations, i.e. the critical mass of tenants does not incorporate the greenness of buildings in leasing decisions. However, the leaders of industries, which are represented by the largest and most visible firms, are deliberately opting for sustainable office space, driven by awareness of reputation effects or the direct payoffs. Especially firms with non-green operations seem eager to compensate the negative reputation effects by acting more responsible in for example housing decisions.

For investors, this might be right time to start investing in sustainable buildings. Industry leaders and early adopters are now including leasing or corporate real estate decisions in their CSR policies, indicating that the business cycle is getting closer to its tipping point, in which the critical mass of end-users will demand high-quality, energy efficient buildings, preferable with a green label. With the supply of green office space still limited, those offering quantity and scale of sustainable buildings will be able to capitalize on the green premium currently available in the market.

\subsection{Suggestions for Further Research}

The global property market is evolving rapidly, with most of the growth taking place via indirect property vehicles. Eichholtz and Kok (2007) provide an overview of REIT structures that have been installed throughout the different continents, and show that especially in the past decade the number of countries with a REIT structure has exploded. However, most of the new markets are still too immature, and the number of listed property companies too limited, to allow for thorough empirical research. Most notable, the Asian market is mostly excluded from the literature, which stands in sharp contrast to its sheer size - approximately as large as the American and European listed property markets - and its fast growth. As indirect property investments are an important venue for international capital allocations, especially for Western institutional investors investing in Asia, it is important to gain insight into agency issues and the effectiveness and structure of corporate governance mechanisms to resolve the agency problems.

Second, Part Two of this dissertation solely focuses on corporate governance in listed property companies. However, correlations between regular equity and listed property stocks have been increasing lately, and the securitized property market has taken a serious blow during the height of the subprime crisis and the subsequent credit crunch. This has stimulated many institutional investors to consider indirect property investments through non-listed property vehicles. These closed-end vehicles usually have fixed investment durations, are externally managed, can be tailor-made to the needs and wants of investors, and resemble direct property investments more closely. One major drawback of non-listed property vehicles is their intransparency. The main industry body, INREV, has defined 'best-practices' regarding fee and governance structures for non-listed property funds, but is struggling with fundamentals, such as to what defines the riskiness of the investment style. The limited availability of data, in combination with the relatively short historical time series, poses severe limitations on academic insights in indirect, non-listed property investments (Brounen, Op 't Veld and Raitio, 2007). Empirical research in this field should be a high priority in future work, as capital inflows to non-listed property funds are rapidly increasing, and investors lack insight in as to how efficient this form of property investment actually is. 
Third, in Part Two, we claim to provide the first credible economic analysis of green buildings. While this is an important step in the understanding the financials of green property investments, it is only the first move in a promising research direction. As noted, we do not yet have access to the information that would allow us to distinguish the market value of energy savings and conservation from the other valuable attributes of a label. But this should be a high priority for future research. Moreover, we lack insight in the initial investment necessary to increase the sustainability of a building, as to obtain a green label. For a straightforward capital-budgeting decision to be complete, it would be helpful to examine the costs of 'greening' existing buildings.

Furthermore, we study the U.S. commercial office market as a laboratory. In a comparable setup, future work should address sustainability in other property sectors, such as retail and residential real estate. The latter is especially important, as more and more countries are implementing 'green' labels in the housing market, to increase energy efficiency and consumer awareness. Academic insight in the functioning of such a label in countries with prior experience, such as the United Kingdom, can be helpful in design and implementation of new labels. Another extension of our U.S. study should be made in international property markets that have a sustainability rating for (commercial) properties. Australia has since long implemented its GreenStar label, the United Kingdom uses an equivalent of LEED - BREEAM, and Japan has the CASSBEE rating system. With the green movement going mainstream and increased investor demand, global insight in the effectiveness of green labels for the real estate sector could help to obtain critical mass of developers and investors. 


\section{Reference List}

Aggarwal, R.K. and Samwick, A.A. "The Other Side of the Trade-Off: The Impact of Risk on Executive Compensation." Journal of Political Economy, 1999, 107(1), pp. 65-105.

Agrawal, A. and Jaffe, J.F. "Do Takeover Targets Underperform? Evidence from Operating and Stock Returns." Journal of Financial \& Quantitative Analysis, 2003, 38(4), pp. 721-46.

Agrawal, A. and Knoeber, C.R. "Firm Performance and Mechanisms to Control Agency Problems between Managers and Shareholders." Journal of Financial and Quantitative Analysis, 1996, 31 (3), pp. 377-97.

Agrawal, A. and Walkling, R.A. "Executive Careers and Compensation Surrounding Takeover Bids." Journal of Finance, 1994, 49(3), pp. 985-1014.

Allen, P.R. and Sirmans, C.F. "An Analysis of Gains to Acquiring Firm's Shareholders: The Special Case of Reits." Journal of Financial Economics, 1987, 18(1). pp. 175-84.

Ambrose, B.W. "Corporate Real Estate's Impact on the Takeover Market." Journal of Real Estate Finance \& Economics, 1990, 3(4), pp. 307-22.

Ambrose, B.W. and Linneman, P. "Reit Organizational Structure and Operating Characteristics." Journal of Real Estate Research, 2001, 21(3), pp. 141-62.

Ambrose, B.W. and Megginson, W.L. "The Role of Asset Structure, Ownership Structure, and Takeover Defenses in Determining Acquisition Likelihood." Journal of Financial \& Quantitative Analysis, 1992, 27 (4), pp. $575-89$.

Apte, M.G.; Fisk, W., J. and Daisey, J.M. " Associations between Indoor Co2 Concentration and Sick Building Syndrome Symptoms in Us Office Buildings: An Analysis of the 1994-1996 Base Study Data." Indoor Air, 2000, 10. pp. 256-27.

Asquith, P.; Bruner, R.F. and Mullins, D.W. "The Gains to Bidding Firms from Mergers." Journal of Financial Economics, 1983, 11 (1-4), pp. 121-39.

Asquith, P. and Kim, E.H. "The Impact of Merger Bids on the Participating Firm's Security Holders." Journal of Finance, 1982, 37(5), pp. 1209-28.

Bansal, P. and Roth, K. "Why Companies Go Green: A Model of Ecological Responsiveness." Academy of Management Journal, 2000, 43(4), pp. 717-37.

Barber, B.M.; Palmer, D. and Wallace, J. "Determinants of Conglomerate and Predatory Acquisitions During the 1960s." Journal of Finance, 1994, 49(3), pp. 1047-48. 
Barnes, P. "Predicting Uk Takeover Targets: Some Methodological Issues and an Empirical Study." Review of Quantitative Finance and Accounting, 1999, 12 (3), pp. 282-302.

Baron, D.P. "Private Politics, Corporate Social Responsibility, and Integrated Strategy." Journal of Economics \& Management Strategy, 2001, 10(1), pp. 7-45.

Bassen, A.; Meyer, K. and Schlange, J. "The Influence of Corporate Responsibility on the Cost of Capital," 2006.

Bauer, R. Verantwoord Beleggen: De Hype Voorbij? Maastricht: Maastricht University, 2008.

Bauer, R.; Eichholtz, P.M.A. and Kok, N. "Corporate Governance and Performance: The Reit Effect." forthcoming Real Estate Economics, 2008.

Bauer, R.; Guenster, N. and Otten, R. "Empirical Evidence on Corporate Governance in Europe: The Effect on Stock Returns, Firm Value, and Performance." Journal of Asset Management, 2004, 5, pp. 91-104.

Baum, A. "Quality and Property Performance." Journal of Property Valuation and Investment, 1994, 12(1), pp. $31-46$.

Baumol, W.J. Business Behavior, Value and Growth. New York: Macmillan, 1959. Perfect Markets and Easy Virtue: Business Ethics and the Invisible Hand. Oxford: Basil Blackwell, 1991.

Bebchuk, L.A. and Fried, J.M. "Pay without Performance: Overview of the Issues." Journal of Applied Corporate Finance, 2005, 17(4), pp. 8-22.

Berger, P.G. and Ofek, E. "Bustup Takeovers of Value-Destroying Diversified Firms." Journal of Finance, 1996, $51(4)$, pp. 1175-200.

Berk, J.B. and Stanton, R. "Managerial Ability, Compensation, and the Closed-End Fund Discount." Journal of Finance, 2007, 62 (2), pp. 529-56.

Bertrand, M. and Schoar, A. "Managing with Style: The Effect of Managers on Firm Policies." Quarterly Journal of Economics, 2003, 118(4), pp. 1169-208.

Bianco, C.; Ghosh, C. and Sirmans, C.F. "The Impact of Corporate Governance on the Performance of Reits." Journal of Portfolio Management, 2007, 33, pp. 175-91.

Black, B.S.; Jang, H. and Kim, W. “Does Corporate Governance Predict Firms' Market Values? Evidence from Korea." Journal of Law, Economics, and Organization, 2006, 22 (2), pp. 366-413. 
Corporate Governance and Sustainability in Global Property Markets

Black, F. and Scholes, M.S. "The Pricing of Options and Corporate Liabilities." Journal of Political Economy, 1973, 81 (3), pp. 637-54.

Boehren, 0. and Odegaard, B.A. "Governance and Performance Revisited," 2003.

Boer, D.; Brounen, D. and Op't Veld, H. "Corporate Focus and Stock Performance: International Evidence from Listed Property Markets." Journal of Real Estate Finance and Economics, 2005, 31 (3), pp. 263-81.

Bollen, N. "Mutual Fund Attributes and Investor Behavior." Journal of Financial and Quantitative Analysis, 2008, $42(3)$, pp. 683-708.

Bollinger, C.R.; Ihlanfeldt, K.R. and Bowes, D.R. "Spatial Variation in Office Rents within the Atlanta Region." Urban Studies, 1998, 35(7), pp. 1097-118.

Bowen, H.R. Social Responsibilities of the Businessman. New York: Harper \& Brothers, 1953.

Brounen, D. and Eichholtz, P.M.A. “Corporate Real Estate Ownership Implications: International Performance Evidence." Journal of Real Estate Finance and Economics, 2005, 30(4), pp. 429-45.

Brounen, D.; Op 't Veld, H. and Raitio, V. "Transparency in the European Non-Listed Real Estate Funds Market." Journal of Real Estate Portfolio Management, 2007, 13(2), pp. 107-18.

Brounen, D. and ter Laak, M. "Understanding the Discount: Evidence from European Property Shares." Journal of Real Estate Portfolio Management, 2005, 11(3), pp. 241-51.

Brown, L.D. and Caylor, M.L. "Corporate Governance and Firm Valuation." Journal of Accounting and Public Policy, 2006, 25(4), pp. 409-34.

Brown, S.J. and Warner, J.B. "Measuring Security Price Performance." Journal of Financial Economics, 1980, 8(3), pp. 205-58.

Buck, T.; Bruce, A.; Main, B.G.M. and Udueni, H. "Long Term Incentive Plans, Executive Pay and Uk Company Performance." Journal of Management Studies, 2003, 40 (7), pp. 1709-27.

Campbell, R.; Ghosh, C. and Sirmans, C.F. "The Information Content of Method of Payment in Mergers: Evidence from Real Estate Investment Trusts (Reits)." Real Estate Economics, 2001, 29(3), pp. 360-87.

Campbell, R.D. "Shareholder Wealth Effects in Equity Reit Restructuring Transactions: Sell-Offs, Mergers and Joint Ventures." Journal of Real Estate Literature, 2002, 10(2), pp. 205-22.

Campbell, R.D.; Ghosh, C. and Sirmans, C.F. "Value Creation and Governance Structure in Reit Mergers." Journal of Real Estate Finance \& Economics, 2005, 31 (2). pp. 225-39. 
Cannon, S.E. and Vogt, S.C. "Reits and Their Management: An Analysis of Organizational Structure, Performance and Management Compensation." Journal of Real Estate Research, 1995, 10(3). pp. 297-317.

Capozza, D.R. and Seguin, P.J. "Debt, Agency, and Management Contracts in Reits: The External Advisor Puzzle." Journal of Real Estate Finance and Economics, 2000, 20(2), pp. 91-116.

"Inside Ownership, Risk Sharing and Tobin's 0-Ratios: Evidence from Reits." Real Estate Economics, 2003, 31(3). pp. 367-404.

Chan, S.H.; Leung, W.K. and Wang, K. "Institutional Investment in Reits: Evidence and Implications." Journal of Real Estate Research, 1998, 16 (3), pp. 357.

Chang, S. "Takeovers of Privately Held Targets, Methods of Payment, and Bidder Returns." Journal of Finance, 1998, 53(2), pp. 773-84.

Chopin, M.C.; Dickens, R.N. and Shelor, R.M. "An Empirical Examination of Compensation of Reit Managers." Journal of Real Estate Research, 1995, 10(3), pp. 263-77.

Conyon, M.J.; Core, J.E. and Guay, W.R. "How High Is Us Ceo Pay? A Comparison with Uk Ceo Pay," 2006.

Conyon, M.J. and Murphy, K.J. "The Prince and the Pauper? Ceo Pay in the United States and United Kingdom." Economic Journal, 2000, 110(467), pp. 640-71.

Core, J.E.; Guay, W.R. and Rusticus, T.O. "Does Weak Governance Cause Weak Stock Returns? An Examination of Firm Operating Performance and Investors' Expectations." Journal of Finance, 2006, 61 (2). pp. 655-87.

Core, J.E.; Holthausen, R.W. and Larcker, D.F. "Corporate Governance, Chief Executive Officer Compensation, and Firm Performance." Journal of Financial Economics, 1999, 51 (3), pp. 371-406.

Coughian, A.T. and Schmidt, R.M. "Executive Compensation, Management Turnover, and Firm Performance: An Empirical Investigation." Journal of Accounting and Economics, 1985, 7(1-3), pp. 43-66.

Cremers, M. and Nair, V.B. "Governance Mechanisms and Equity Prices." Journal of Finance, 2005, 60 (6). pp. 2859-94.

Creyer, C.H. and Ross, W.T. "The Influence of Firm Behavior on Purchase Intention: Do Consumers Really Care About Business Ethics?" Journal of Consumer Marketing, 1997, 14 (6), pp. 421-32

CSBTF. "The Costs and Financial Benefits of Green Buildings." 2003.

Derwall, J. "The Virtues and Consequences of CSR," 2007. 
Derwall, J.; Guenster, N.; Bauer, R. and Koedijk, K. "The Eco-Efficiency Premium Puzzle." Financial Analysts Journal, 2005, 61(2), pp. 51-63.

Dietrich, J.K. and Sorensen, E. "An Application of Logit Analysis to Prediction of Merger Targets." Journal of Business Research, 1984, 12(3), pp. 393-402.

Dimson, E. and Minio-Kozerski, C. "Closed-End Funds: A Survey." Financial Markets, Institutions and Instruments, 1999, 8 (2), pp. 1-41.

Dodd, P. "Merger Proposals, Management Discretion and Stockholder Wealth." Journal of Financial Economics, 1980, 8(2), pp. 105-38.

Dodd, P. and Ruback, R. "Tender Offers and Stockholder Returns." Journal of Financial Economics, 1977, 5(3), pp. 351-73.

Downs, D.H.; Guener, Z.N. and Patterson, G.H. "Capital Distribution Policy and Information Asymmetry: A Real Estate Market Perspective." Journal of Real Estate Finance and Economics, 2000, 21 (3), pp. 235-50.

Drobetz, W.; Schillhofer, A. and Zimmermann, H. "Corporate Governance and Expected Stock Returns: Evidence from Germany." European Financial Management, 2004, 10(2), pp. 267-93.

Durnev, A. and Kim, E.H. "To Steal or Not to Steal: Firm Attributes, Legal Environment, and Valuation." Journal of Finance, 2005, 603), pp. 1461-93.

Edmans, A. "Employee Satisfaction and Equity Prices," 2007.

Eichholtz, P.M.A. "A Long Run House Price Index: The Herengracht Index, 1628-1973." Real Estate Economics, 1997, 25(2), pp. 175-92.

Eichholtz, P.M.A.; Koedijk, K. and Schweitzer, M. “Global Property Investment and the Costs of International Diversification." Journal of International Money \& Finance, 2001, 20(3), pp. 349-66.

Eichholtz, P.M.A. and Kok, N. "The EU Reit and the Internal Market for Real Estate," 2007.

"How Does the Market for Corporate Control Function for Property Companies?" Journal of Real Estate Finance \& Economics, 2008, 36 (2), pp. 141-63.

Eichholtz, P.M.A.; Kok, N. and Otten, R. "Executive Compensation in Uk Property Companies." Journal of Real Estate Finance and Economics, 2008a, 36 (4), pp. 405-26.

Eichholtz, P.M.A.; Kok, N. and Quigley, J.M. "Doing Good by Doing Well: Green Office Buildings," 2008b. 
Ellert, J.C. "Mergers, Antitrust Law Enforcement and Stockholder Returns." Journal of Finance, 1976, 31 (2). pp. $715-32$.

EPRA. "Best Practices: Policy and Recommendations." 2004.

Fama, E.F. and French, K.R. "Industry Costs of Equity." Journal of Financial Economics, 1997, 43 (2), pp. 153-93.

Fama, E.F. and MacBeth, J.D. "Risk, Return, and Equilibrium: Empirical Tests." Journal of Political Economy, $1973,81(3)$, pp. 607.

Fisk, W., J. and Rosenfeld, A.H. "Estimates of Improved Productivity and Health from Better Indoor Environments." Indoor Air, 1997, 7. pp. 158-72.

Fombrun, C. Reputation: Realizing Value from the Corporate Image. Boston: Harvard Business School Press, 1996.

Fombrun, C. and Shanley, M. "What's in a Name? Reputation Building and Corporate Strategy." The Academy of Management Journal, 1990, 33 (2), pp. 233-58.

Foreh, M.R. and Grier, S. "When Is Honesty the Best Policy? The Effect of Stated Company Intent on Consumer Skepticism." Journal of Consumer Psychology, 2003, 13(3), pp. 349-56.

Franks, J.; Harris, R.S. and Mayer, C. "Means of Payment in Takeovers: Results for the United Kingdom and the United States," A. Auerbach, Corporate Takeovers: Causes and Consequences. Chicago: NBER, 1988,

Franks, J. and Mayer, C. "Hostile Takeovers and the Correction of Managerial Failure." Journal of Financial Economics, 1996, 40(1), pp. 163-81.

Friday, H.S. and Sirmans, G.S. "Board of Director Monitoring and Firm Value in Reits." Journal of Real Estate Research, 1998, 16(3), pp. 411.

Friday, H.S.; Sirmans, G.S. and Conover, C.M. "Ownership Structure and the Value of the Firm: The Case of Reits." Journal of Real Estate Research, 1999, 17(1/2), pp. 71.

Friedman, M. "The Social Responsibility of Business is to Increase Its Profits," 1970.

Fuerst, F. and McAllister, P. "Does It Pay to Be Green? Connecting Economic and Environmental Performance in Commercial Real Estate Markets," 2008.

Gertler, M. and Hubbard, R.G. Financial Factors in Business Fluctuations Kansas City: Federal Reserve Bank of Kansas City, 1988. 
Ghosh, C. and Sirmans, C.F. "Board Independence, Ownership Structure and Performance: Evidence from Real Estate Investment Trusts." Journal of Real Estate Finance \& Economics, 2003a, 26 (2/3), pp. 287-318.

"Board Independence, Ownership Structure and Performance: Evidence from Real Estate Investment

Trusts." Journal of Real Estate Finance \& Economics, 2003b, 26 (2-3), pp. 287-318.

"Do Managerial Motives Impact Dividend Decisions in Reits." Journal of Real Estate Finance \&

Economics, 2006, 32, pp. 327-55.

"On Reit Ceo Compensation: Does Board Structure Matter?" Journal of Real Estate Finance and

Economics, 2005, 30(4), pp. 397-428.

Gibbons, R. and Murphy, K.J. "Optimal Incentive Contracts in the Presence of Career Concerns: Theory and Evidence." Journal of Political Economy, 1992, 100 (3), pp. 468-505.

Glasscock, J.L.; Johanian, S. and Sirmans, C.F. "An Analysis of Office Market Rents." AREUEA Journal, 1990, 18 . pp. 105-19.

Goetzmann, W.N. and Ibbotson, R.G. "The Performance of Real Estate as an Asset Class." Journal of Applied Corporate Finance, 1990, 3(1), pp. 65-76.

Gompers, P.A.; Ishii, J. and Metrick, A. "Corporate Governance and Equity Prices." Quarterly Journal of Economics, 2003, $118(1)$, pp. 107.

Graham, J.R.; Lemmon, M.L. and Wolf, J.G. "Does Corporate Diversification Destroy Value?" Journal of Finance, 2002, 57(2), pp. 695-720.

“Directors' Remuneration Report," Gee Publishing: London, 1995.

Guenster, N.; Derwall, J.; Bauer, R. and Koedijk, K. "The Economic Value of Corporate Eco-Efficiency," 2005.

Gunnelin, A. and Söderberg, B. "Term Structures in the Office Rental Market in Stockholm " Journal of Real Estate Finance and Economics, 2003, 26 (2-3), pp. 241-65.

Hall, B.J. and Liebman, J.B. "Are Ceos Really Paid Like Bureaucrats?" Quarterly Journal of Economics, 1998, 113 (3), pp. 653-91.

"Final Report on Corporate Governance," Gee Publishing: London, 1998.

Han, B. "Insider Ownership and Firm Value: Evidence from Real Estate Investment Trusts." Journal of Real Estate Finance and Economics, 2006, 32 (4), pp. 471-93. 
Hanushek, E. "Efficient Estimators for Regressing Regression Coefficients." American Statistician, 1974, 28(2). pp. 66-67.

Hartzell, J.C.; Kallberg, J.G. and Liu, C.H. "The Role of Corporate Governance in Initial Public Offerings: Evidence from Real Estate Investment Trusts," 2004.

Hartzell, J.C.; Sun, L. and Titman, S. "The Effect of Corporate Governance on Investment: Evidence from Real Estate Investment Trusts." Real Estate Economics, 2006, 34 (3), pp. 343-76.

Hong, H. and Kacperczyk, M. "The Price of Sin: The Effects of Social Norms of Markets," 2007.

Howe, J.S. and Shilling, J.D. "Reit Advisor Performance." American Real Estate and Urban Economics Association Journal, 1990, 18(4), pp. 479-500.

Hsieh, C. and Sirmans, C.F. "Reits as Captive-Financing Affiliates: Impact on Financial Performance." Journal of Real Estate Research, 1991, 6, pp. 179-90.

Hyun, S. "The Effects of Overpayment and Form of Financing on Bidder Returns in Mergers and Tender Offers." Journal of Financial Research, 1993, 16 (4), pp. 351-65.

Jensen, M.C. "Agency Costs of Free Cash Flow, Corporate Finance, and Takeovers." American Economic Review, 1986, 76 (2), pp. 323-29.

"Takeovers: Their Causes and Consequences." Journal of Economic Perspectives, 1988, 2(1), pp. 21-48.

Jensen, M.C. and Murphy, K.J. "Performance Pay and Top-Management Incentives." Journal of Political Economy, 1990, 98(2), pp. 225-64.

Jensen, M.C. and Ruback, R.S. "The Market for Corporate Control." Journal of Financial Economics, 1983, $11(1-4)$, pp. 5-50.

Kallberg, J.G.; Liu, C.H. and Srinivasan, A. "Dividend Pricing Models and Reits." Real Estate Economics, 2003, 31 (3 \%R doi:10.1111/1540-6229.00072), pp. 435-50.

Kassinis, G. and Vafeas, N. "Corporate Boards and Outside Stakeholders as Determinants of Environmental Litigation." Strategic Management Journal, 2002, 23(5), pp. 399-415.

Kats, G. "Green Buildings Costs and Financial Benefits," 2003.

Khanna, M. and Damon, L.A. "Epa's Voluntary 33/50 Program: Impact on Toxic Releases and Economic Performance of Firms." Journal of Environmental Economics and Management, 1999, 37(1), pp. 1-25. 
Kini, 0.; Kracaw, W. and Mian, S. "The Nature of Discipline by Corporate Takeovers." Journal of Finance, 2004, 59(4), pp. 1511-52.

Klapper, L.F. and Love, I. "Corporate Governance, Investor Protection, and Performance in Emerging Markets." Journal of Corporate Finance, 2004, 10 (5), pp. 703-28.

Klein, B. and Leffler, K.B. "The Role of Market Forces in Assuring Contractual Performance." The Journal of Political Economy, 1981, 89(4), pp. 615-41.

La Porta, R.; Lopez-De-Silanes, F.; Shleifer, A. and Vishny, R. "Agency Problems and Dividend Policies around the World." Journal of Finance, 2000, 55(1-33)

_. "Investor Protection and Corporate Valuation." Journal of Finance, 2002, 57(3), pp. 1113-55.

"Law and Finance." Journal of Political Economy, 1998, 106 (1113-55).

Langetieg, T.C. "An Application of a Three-Factor Performance Index to Measure Stochholder Gains from Merger." Journal of Financial Economics, 1978, 6(4), pp. 365-83.

Lee, S.L. "The Relative Importance of Property Type and Regional Factors in Real Estate Returns." Journal of Real Estate Portfolio Management, 2001, 7(2), pp. 159-67.

Ling, D.C. and Ryngaert, M. "Valuation Uncertainty, Institutional Involvement, and the Underpricing of Ipos: The Case of Reits." Journal of Financial Economics, 1997, 43(3), pp. 433-56.

Lyon, T.P. and Maxwell, J.W. "Greenwash: Corporate Environmental Disclosure under Threat of Audit," 2006.

Main, B.G.M.; Bruce, A. and Buck, T. "Total Board Remuneration and Company Performance." Economic Journal, 1996, 106 (439), pp. 1627-44.

Malatesta, P.H. "The Wealth Effect of Merger Activity and the Objective Functions of Merging Firms." Journal of Financial Economics, 1983, 11 (1-4), pp. 155-81.

Mandelker, G. "Risk and Return: The Case of Merging Firms." Journal of Financial Economics, 1974, 1 (4), pp. 303-35.

Manne, H.G. "Mergers and the Market for Corporate Control." Journal of Political Economy, 1965, 73(2), pp. $110-20$.

Margolis, J.D. and Walsh, J.P. "Misery Loves Company: Rethinking Social Initiatives by Business." Administrative Science Quarterly, 2003, 48(2), pp. 268-305. 
Martin, K.J. and McConnell, J.J. "Corporate Performance, Corporate Takeovers, and Management Turnover." Journal of Finance, 1991, 46(2), pp. 671-87.

Maxwell, J.W.; Lyon, T.P. and Hackett, S.C. "Self-Regulation and Social Welfare: The Political Economy of Corporate Environmentalism " Journal of Law and Economics, 2000, 43 (2). pp. 583-617.

McIntosh, W.; Officer, D.T. and Born, J.A. "The Wealth Effects of Merger Activities: Further Evidence from Real Estate Investment Trusts." Journal of Real Estate Research, 1989, 4(3), pp. 141-55.

Mikkelson, W.H. and Partch, M.M. "Managers' Voting Rights and Corporate Control." Journal of Financial Economics, 1989, 25 (2). pp. 263-90.

Miles, M.P. and Covin, J.G. "Environmental Marketing: A Source of Reputational, Competitive, and Financial Advantage." Journal of Business Ethics, 2000, 23(3), pp. 299-311.

Milgrom, P. and Roberts, J. "Price and Advertising Signals of Product Quality." Journal of Political Economy, 1986, 94 (4), pp. 796-821.

CoStar. “Does Green Pay Off?," Bethesda, MD, 2008.

Mishra, C.S. and Nielsen, J.F. "Board Independence and Compensation Policies in Large Bank Holding Companies." Financial Management, 2000, 29(3), pp. 51-69.

Mitchell, M.L. and Lehn, K. "Do Bad Bidders Become Good Targets?" Journal of Political Economy, 1990, 98(2), pp. 372-98.

Mitchell, R.K.; Agle, B.R. and Wood, D.J. "Toward a Theory of Stakeholder Identification and Salience: Defining the Principle of Who and What Really Counts." Academy of Management Review. 1997, 22 (4), pp. 853-86.

Moeller, S.B.; Schlingemann, F.P. and Stulz, R.M. "Firm Size and the Gains from Acquisitions." Journal of Financial Economics, 2004, 73(2), pp. 201-28.

Mood, A.M.F.; Graybill, F.A. and Boes, B.C. Introduction to the Theory of Statistics. New York: McGraw-Hill, 1974.

Morck, R.A.; Shleifer, A. and Vishny, R.W. "Characteristics of Targets of Hostile and Friendly Takeovers," Corporate Takeovers: Causes and Consequences. Chicago: NBER, 1988,

Murphy, K.J. “Executive Compensation," 0. Ashenfelter and D. Card, Handbook of Labor Economics. Amsterdam: Elsevier, 1999, 2485-563. 
Corporate Governance and Sustainability in Global Property Markets

Myer, F.C.N. and Webb, J.R. "Management Styles of Reit Funds." Journal of Real Estate Portfolio Management, 2000, 6(4), pp. 339-48.

Myers, S.C. and Majluf, N.S. "Corporate Financing and Investment Decisions When Firms Have Information That Investors Do Not Have." Journal of Financial Economics, 1984, 13(2), pp. 187-221.

North, D. "The Role of Mangerial Incentives in Corporate Acquisitions: The 1990s Evidence." Hournal of Corporate Finance, 2001, 7, pp. 125-49.

Orlitzky, M. and Benjamin, J.D. "Corporate Social Performance and Firm Risk: A Meta-Analytic Review" Business and Society, 2001, 40(4), pp. 369-96.

Öven, V.A. and Pekdemir, D. "Office Rent Determinants Utilising Factor Analysis - a Case Study for Istanbul." Journal of Real Estate Finance and Economics, 2006, 33(1), pp. 51-73.

Palepu, K.G. "Predicting Takeover Targets." Journal of Accounting \& Economics, 1986, 8(1), pp. 3-35.

Pennathur, A.K.; Gilley, O.W. and Shelor, R.M. "An Analysis of Reit Ceo Stock-Based Compensation." Real Estate Economics, 2005, 33(1), pp. 189-202.

Pennathur, A.K. and Shelor, R.M. "The Determinants of Reit Ceo Compensation." Journal of Real Estate Finance and Economics, 2002, 25 (1), pp. 99-113.

Porter, M.E. and Van der Linde, C. "Green and Competitive: Ending the Stalemate." Harvard Business Review, 1995, 73(5), pp. 120-34.

Quigley, J.M. "Market Induced and Government Mandated Energy Conservation in the Housing Market: Econometric Evidence from the U.S." Review of Urban and Regional Development Studies, 1991, 3(1), pp. 28-38. "The Production of Housing Services and the Derived Demand for Residential Energy." The RAND Journal of Economics, 1984, 15(4), pp. 555-67.

"Residential Energy Standards and the Housing Market: A Regional Analysis." Papers of the Regional Science Association, 1985, 54.

Quigley, J.M. and Rubinfield, D.L. "Unobservables in Consumer Choice: Residential Energy and the Demand for Comfort." Review of Economics \& Statistics, 1989, 71 (3), pp. 415-25.

Ramus, C.A. and Montiel, I. "When Are Corporate Environmental Policies a Form of Greenwashing?" Business and Society, 2005, 44 (4), pp. 377-414.

Rappaport, A. "The Staying Power of the Public Corporation." Harvard Business Review, 1990, 68(1), pp. 96-104. 
Renneboog, L.; Ter Horst, J. and Zhang, C. "Socially Responsible Investments: Institutional Aspects, Performance, and Investor Behavior." Journal of Banking \& Finance, 2008, forthcoming.

RICS. "Green Value," London and Vancouver, 2005.

Rogers, W. "Regression Standard Errors in Clustered Samples." Stata Technical Bulletin, 1993, 13, pp. 19-23.

Rosen, K. "Toward a Model of the Office Building Sector." AREUEA Journal, 1984, 12, pp. 261-69

Rosen, S. "Contracts and the Market for Executives," L. Werin and H. Wijkander, Contract Economics. Malden, MA: Blackwell Publishers, 1992, 181-211.

Schelling, T.S. "Some Economics of Global Warming." American Economic Review, 1992، 82 (1), pp. 1-14.

Shleifer, A. and Vishny, R.W. "Large Shareholders and Corporate Control." Journal of Political Economy, 1986, 94(3), pp. 461-88.

Schwert, G.W. "Hostility in Takeovers: In the Eyes of the Beholder?" Journal of Finance, 2000, 55 (6), pp. 2599640 .

Scott, J.L.; Anderson, R.I. and Loviscek, A.L. "Are Reit Ceos Rewarded for Performance? Another Look." Journal of Real Estate Portfolio Management, 2001, 7(3), pp. 247-52.

Servaes, H. "Tobin's 0 and Gains from Takeovers." Journal of Finance, 1991, 46 (1), pp. 409-19.

Shin, H.H. and Stulz, R.M. "Firm Value, Risk, and Growth Opportunities," 2000.

Shivdasani, A. "Board Composition, Ownership Structure, and Hostile Takeovers." Journal of Accounting \& Economics, 1993, 16 (1-3), pp. 167-98.

Shleifer, A. "Does Competition Destroy Ethical Behavior?" American Economic Association Papers and Proceedings, 2004, $94(2)$, pp. 122-42.

SIF. "Report on Socially Responsible Investing Trends in the United States," 2007.

Sirmans, C.F. "Research on Reit Corporate Governance." Real Estate Finance (Euromoney Institutional Investor PLC), 1997, 14(3), pp. 75-79.

Sivitanidou, R. "Do Office-Commercial Firms Value Access to Service Employment Centers? A Hedonic Value Analysis within Polycentric Los Angeles." Journal of Urban Economics, 1996, 40(2), pp. 125-49

"Urban Spatial Variations in Office-Commercial Rents." Journal of Urban Economics, 1995, 38 (1). pp. 23-49. 
Smiley, R. "Tender Offers, Transaction Costs and the Theory of the Firm." Review of Economics \& Statistics, 1976, 58(1), pp. 22-32.

Song, M.H. and Walkling, R.A. "The Impact of Managerial Ownership on Acquisition Attempts and Target Shareholder Wealth." Journal of Financial \& Quantitative Analysis, 1993, 28(4), pp. 439-57.

Sonnenfeld, J. "Good Governance and the Misleading Myths of Bad Metrics." Academy of Management Executive, 2004, 18(1), pp. 108-13.

Spicer, B.H. "Investors, Corporate Social Performance and Information Disclosure: An Empirical Study." The Accounting Review, 1978, 53(1), pp. 94-111.

Stein, J.C. "Takeover Threats and Managerial Myopia." Journal of Political Economy, 1988, 96 (1), pp. 61-80.

Strahilevitz, M. "The Effects of Prior Impressions of a Firm's Ethics on the Success of a Cause-Related Marketing Campaign: Do the Good Look Better While the Bad Look Worse?,"W. W. Wymer and S. Samu, Nonprofit and Business Sector Collaboration. Philadelphia: Haworth Press، 2003,

Subrahmanyam, V. and Rangan, N. "The Role of Outside Directors in Bank Acquisitions." Financial Management (Financial Management Association ), 1997, 26 (3), pp. 23-36.

Taylor, F. Scientific Management. New York: Harper Brothers, 1911.

Trahan, E.A. "Financial Characteristics of Acquiring Firms and Their Relation to the Wealth Effects of Acquisition Announcements." Journal of Economics \& Finance, 1993, 17(2), pp. 21-35.

Travlos, N.G. "Corporate Takeover Bids, Methods of Payment, and Bidding Firm's Stock Returns." Journal of Finance, 1987, 42 (4), pp. 943-63.

Turban, D.B. and Greening, D.W. "Corporate Social Performance and Organizational Attractiveness to Prospective Employees." Academy of Management Journal, 1997, 40(3), pp. 658-72.

Vandermerwe, S. and Oliff, M.D. "Customers Drive Corporations Green." Long Range Planning, 1990, 23(6), pp. 10-16.

Waddock, S.A. and Graves, S.B. "The Corporate Social Performance-Financial Performance Link." Strategic Management Journal, 1997, 18(4), pp. 303-19.

Wang, K.; Erickson, J. and Gau, G. "Dividend Policies and Dividend Announcement Effects for Real Estate Investment Trusts." Real Estate Economics, 1993, 21, pp. 185-201.

WBCSD. "Changing Course: A Global Business Perspective on Development and the Environment," Washington D.C. and Geneva, 2002. 
Webb, R.; Beck, M. and McKinnon, R. "Problems and Limitations of Institutional investor Participation in Corporate Governance." Corporate Governance: An International Review, 2003, 11 (1). pp. 65-73.

Webb, R.B. and Fisher, J.D. "Development of an Effective Rent Index for the Chicago Cbd." Journal of Urban Economics, 1996, 39, pp. 1-19.

Wei, P.; Hsieh, C.-H. and Sirmans, C.F. "Captive Financing Arrangements and Information Asymmetry: The Case of Reits." Real Estate Economics, 1995, 23(3), pp. 385-94.

Weir, C. "Corporate Governance, Performance and Take-Overs: An Empirical Analysis of Uk Mergers." Applied Economics, 1997. 29(11), pp. 1465-75.

Weir, C. and Laing, D. "Ownership Structure, Board Composition and the Market for Corporate Control in the Uk: An Empirical Analysis." Applied Economics, 2003, 35(16), pp. 1747-59.

Wheaton, W.C. and Torto, R. "Office Rent Indices and Their Behavior over Time." Journal of Urban Economics, 1994, 35, pp. 121-39.

Whidbee, D.A. "Board Composition and Control of Shareholder Voting Rights in the Banking Industry." Financial Management (Financial Management Association ), 1997, 26 (4), pp. 27-41.

White, H. "A Heteroskedasticity-Consistent Covariance Matrix Estimator and a Direct Test for Heteroskedasticity." Econometrica, 1980, 48(4), pp. 817-38.

Wood, D.J. "Corporate Social Performance Revisited." Academy of Management Review, 1991, 16, pp. 691-718.

Yoon, Y.; Gurhan-Canli, Z. and Bozok, B. "Drawing Inferences About Others on the Basis of Corporate Associations." Journal of the Academy of Marketing Science, 2006, 34 (2), pp. 167-73.

Zhou, X. "Ceo Pay, Firm Size, and Corporate Performance: Evidence from Canada." Canadian Journal of Economics, 2000, 33(1), op. 213-51.

. "Understanding the Determinants of Managerial Ownership and the Link between Ownership and

Performance: Comment." Journal of Financial Economics, 2001, 62 (3), pp. 559-71.

Zingales, L. "In Search of New Foundations." Journal of Finance, 2000, 55(4), pp. 1623-53. 


\section{Samenvatting}

In de institutionele portefeuille heeft vastgoed zich de afgelopen decennia ontwikkeld van een alternatieve investering naar de derde investeringscategorie, naast aandelen en obligaties. Institutionele investeerders verruilen directe blootstelling aan vastgoed echter steeds meer voor indirecte vastgoedinvesteringen, middels investeringen in vastgoedfondsen. Deze verandering werd initieel ingegeven uit hoofde van kostenefficiëntie. Bijkomende voordelen zijn een grotere liquiditeit en het vergemakkelijken van internationale diversificatie. Recente vastgoedfraudezaken in Nederland hebben dit proces enkel versneld.

Een belangrijk gevolg van de institutionalisering van de vastgoedsector is de noodzaak tot gestructureerd toezicht op de controlerende entiteit. Andere sectoren hebben dit proces reeds lang ervaren. Toezicht op de indirecte vastgoedsector wordt gecompliceerd door de specifieke karakteristieken van de onderliggende investering en de fiscaal-juridische structuur van vastgoedfondsen. In de globale vastgoedmarkt opereren deze vaak als Real Estate Investment Trust (REIT), in Nederland beter bekend als de fiscale beleggingsinstelling (fbi). De fiscale transparantie van een REIT plaatst het op gelijke voet met een directe investering in vastgoed, aangezien de entiteit gevrijwaard is van vennootschapsbelasting. $0 \mathrm{~m}$ in aanmerking te komen voor een dergelijke fiscale behandeling moet de REIT wel voldoen aan een veelvoud van eisen. De meest belangrijke eis is een verplichte $90 \%$ tot $100 \%$ uitkering van de netto winst.

Hoofdstukken twee, drie en vier van dit proefschrift gaan nader in op de structuur en werking van toezichtmechanismen in de globale vastgoedsector.

Hoofdstuk twee is een empirische studie naar de werking van de overnamemarkt bij beursgenoteerde vastgoedfondsen. De overnamemarkt is een disciplinerend mechanisme voor managers en daarmee een belangrijk onderdeel van corporate governance. In de vastgoedsector zijn vijandige overnames viijwel afwezig. Dit leidt tot de vraag in hoeverre de markt voor toezicht effectief is voor beursgenoteerde vastgoedfondsen. Hoofdstuk twee toont aan dat vastgoedfondsen die relatief slecht presteren een grotere kans hebben om overgenomen te worden dan goed presterende fondsen, hetgeen impliceert dat de overnamemarkt voor de beursgenoteerde vastgoedsector een reinigende werking heeft. Bovendien zijn de structuur van de vastgoedportefeuille en de aanwezigheid van verscheidene governance mechanismen bepalend voor de kans om bieder of juist doel te zijn in een overname. Verder zijn overnames in bescheiden mate winstgevend voor aandeelhouders van vastgoedfondsen die overgenomen worden en is er geen significant effect voor de beurskoers van bieders. Wij verklaren dit aan de hand van geringe synergiemogelijkheden bij overnames van vastgoedfondsen en de relatief transparante bedrijfsstructuur.

Het derde hoofdstuk gaat in op de beloning van topmanagers in de Britse vastgoedsector. Eerdere studies keken enkel naar Amerikaanse REITs, maar de vraag is in hoeverre deze resultaten gedreven worden door de REIT-structuur of door de vastgoedspecifieke karakteristieken. Wij vinden dat de sterkst verklarende variabele voor de hoogte van beloning, de grootte van een vastgoedfonds is. De relatie tussen financiële prestaties en beloning is op zijn best zwak te noemen en geldt enkel voor beloningscomponenten als aandelen en opties. Verder heeft de stijl van managers - gereflecteerd in strategische keuzes als sector, diversificatie en internationalisering - een duidelijke invloed op compensatieniveaus. De compensatiestructuur van vastgoedfondsen zonder REIT structuur vertoont veel overeenkomsten met de beloning van topmanagers 
in REITs. Echter, driifveren en componenten van beloningspakketten in de vastgoedsector zijn substantieel verschillend van die in andere sectoren.

Het vierde hoofdstuk van dit proefschrift is een studie naar de structuur van toezichtmechanismen bij Amerikaanse REITs en de relatie met waardering en financiële prestaties. De institutionele omgeving waarin REITs opereren leidt tot twee contrasterende hypothesen: 1) toezicht is minder belangrijk gezien de beperkte operationele vrijheid van topmanagers en 2) bedrijfsspecifiek toezicht is nog steeds noodzakelijk en de sterkte hiervan zal - net als in andere sectoren - gerelateerd zijn aan waardering op de beurs. In lijn met de eerste hypothese vinden wij geen relatie tussen de sterkte van bedrijfsspecifiek toezicht en financiële prestaties, terwijl een dergelijke relatie wel aanwezig is voor de sample van reguliere bedrijven. Wij verklaren dit als een REIT effect: het beperkende institutionele kader is in ieder geval gedeeltelijk een substituut voor alternatieve toezichtmechanismen.

Met de institutionalisering van de vastgoedsector, voornamelijk middels indirecte vastgoedinvesteringen, wordt het belang van toezicht - of corporate governance - groter. Echter, waar dit toezicht zich traditioneel gezien voornamelijk richtte op het beperken van het belangenconflict tussen aandeelhouder en topmanager, hebben institutionele investeerders ook in toenemende mate aandacht voor de verdere maatschappelijke verantwoordelijkheid van bedrijven. Deze maatschappelijke verantwoordelijkheid bevat een duurzaamheidscomponent, alsmede een sociaal element. Voor de gevestigde investeringscategorieën als aandelen en obligaties is het middels velerlei (commerciële) ratings mogelijk om bedrijven te beoordelen op hun duurzame status. Echter, institutionele investeerders hebben moeite hun vastgoedinvesteringen door te lichten op duurzaamheid. Dit wordt mede veroorzaakt door de premature status van het thema duurzaamheid in de vastgoedsector. Al is dit thema in de vastgoedsector niet langer onbesproken. Met 30 procent van de globale $\mathrm{CO}_{2}$ uitstoot veroorzaakt door de gebouwde omgeving, strenger wordende regelgeving ten aanzien van bouweisen en de introductie van duurzaamheidslabels voor commercieel vastgoed, groeit het besef bij ontwikkelaars en beleggers dat duurzaamheid niet alleen een bedreiging is, maar ook een kans biedt. Echter, er heerst nog altijd scepsis en onzekerheid ten aanzien van de economische rationaliteit van duurzaam vastgoed. De marginale bouwkosten zijn ondoorzichtig en empirisch bewijs betreffende rendement bestaat voornamelijk uit "case studies". Dit bewijs is nodige om kritische massa te genereren in duurzame vastgoedontwikkeling.

Hoofdstuk vijf dicht een deel van de empirische kloof. De Amerikaanse vastgoedmarkt kent een brede implementatie van een label voor energie efficiëntie - Energy Star - en een specifiek label voor duurzaamheid - LEED. Verder is de Amerikaanse markt relatief transparant voor wat betreft financiële gegevens en kwalitei tskarakteristieken van commercieel vastgoed. Dit levert een unieke steekproef op van kantoorpanden met een 'groen' label. De vergelijking met een robuuste controle sample toont opvallende resultaten: panden met een duurzaamheidslabel hebben een 2 procent hogere huur, een hogere bezettingsgraad en daardoor een 6 procent hogere effectieve huur en een 16 procent hogere transactieprijs. De bevindingen lijken voornamelijk gedreven te zijn door de energiezuinige panden. Deze resultaten kunnen ontwikkelaars en beleggers ondersteunen in het creëren van een objectieve business case voor het implementeren van duurzaamheid in kantoorpanden.

In het laatste empirische hoofdstuk gaan wij nader in op de rol van eindgebruikers van duurzame kantoorpanden. Er zijn vier theoretische motivaties om te huren in een duurzaam pand: 1) lagere gebruikerskosten en hogere arbeidsproductiviteit, 2) een reputatie effect wat via de arbeidsmarkt en afzetmarkt een feedback effect kan 
hebben, 3) bescherming tegen toekomstige wet- en regelgeving en 4) een intrinsieke motivering waarbij de keuze een niet-financiële waarde heeft. Informatie betreffende de vijf grootste huurders in duurzame kantoorpanden en een controle sample stelt ons, in beperkte mate, in staat om deze hypothesen empirisch te testen. Wij vinden dat voornamelijk de leiders in de verschillende industrieën duurzame kantoorruimte huren, vooral in de olie industrie en de service sector. Echter, alleen voor overheid en non-profit instanties vinden wij een systematisch hogere kans op het huren van duurzame kantoorruimte. Dit geeft aan dat de ontwikkelingen omtrent duurzaam vastgoed nog in de kinderschoenen staan, mede ingegeven door het nog beperkte aanbod van duurzame panden en het tot op heden ontbreken van bewijs betreffende het financiële rendement van duurzaamheid in de vastgoedsector.

Concluderend, dit proefschrift draagt bij aan het verder inzichtelijk maken van vastgoed als volwaardige investeringscategorie, enerzijds door empirische studies naar de effectiviteit van toezichtmechanismen, anderzijds door het leveren van het eerste academische bewijs naar het financiële rendement van duurzaamheid in commercieel vastgoed. De implicaties hiervan zijn relevant voor internationale vastgoedbeleggers alsmede voor aan vastgoed gerelateerde beleidsmakers. 